WSRC-TR-98-00432, Rev. 0

\title{
TNX GeoSiphon Cell (TGSC-1) Phase II Single Cell Deployment/Demonstration Final Report
}

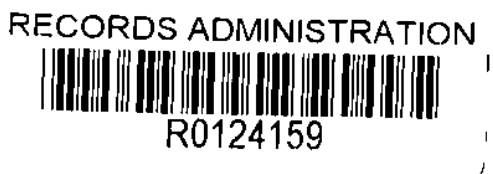

by

M. A. Phifer

Westinghouse Savannah River Company

Savannah River Site

Aiken, South Carolina 29808

F. C. Seppington

R. L. Nichols

K. L. Dixon

DOE Contract No. DE-AC09-96SR18500

This paper was prepared in connection with work done under the above contract number with the U. S.

Department of Energy. By acceptance of this paper, the publisher and/or recipient acknowledges the U. S. Government's right to retain a nonexclusive, royalty-free license in and to any copyright covering this paper, along with the right to reproduce and to authorize others to reproduce all or part of the copyrighted paper. 
PHASE II SINGLE CELL DEPLOYMENT / DEMONSTRATION FINAL REPORT (U)

Mark A. Phifer, SRTC/EST

F. C. Sappington, SRTC/EST

R. L. Nichols, SRTC/EST

K. L. Dixon, SRTC/EST

Westinghouse Savannah River Company

Savannah River Site

Aiken SC, 29808 


\section{DISCLAIMER}

This report was prepared as an account of work sponsored by an agency of the United States Government. Neither the United States Government nor any agency thereof, nor any of their employees, makes any warranty, express or implied, or assumes any legal liability or responsibility for the accuracy, completeness, or usefulness of any information, apparatus, product, or process disclosed, or represents that its use would not infringe privately owned rights. Reference herein to any specific commercial product, process, or service by trade name, trademark, manufacturer, or otherwise does not necessarily constitute or imply its endorsement, recommendation, or favoring by the United States Government or any agency thereof. The views and opinions of authors expressed herein do not necessarily state or reflect those of the United States Government or any agency thereof.

This report has been reproduced directly from the best available copy.

Available to DOE and DOE contractors from the Office of Scientific and Technical Information, P.O. Box 62, Oak Ridge, TN 37831; prices available from (615) 576-8401.

Available to the public from the National Technical Information Service, U.S. Department of Commerce, 5285 Port Royal Road, Springfield, VA 22161. 


\section{TNX GEOSIPHON CELL (TGSC-1)}

PHASE II SINGLE CELL

DEPLOYMENT / DEMONSTRATION FINAL REPORT (U)

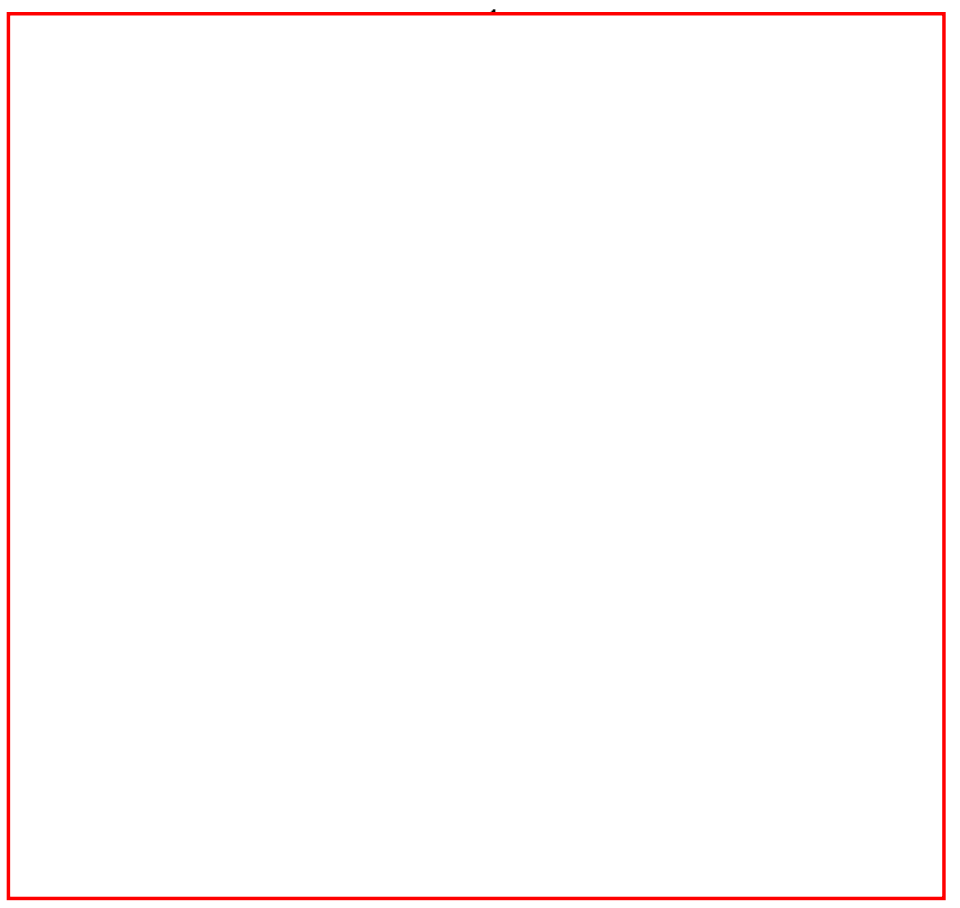

Westinghouse Savannah River Company

Savannah River Site

Aiken SC, 29808 
Acknowledgments:

Appreciation is expressed to the following Environmental Sciences and Technology Department personnel for their contributions to this work:

- T. R. Jarosch for assistance with chlorinated volatile organic compound data reduction.

- C. J. Berry for chlorinated volatile organic compound and microbial density analyses, and review of the microbial density portions of this report.

- C. R. Betivas for sample collection.

- S. L. Baxley for chlorinated volatile organic compound analysis. 


\section{TABLE OF CONTENTS}

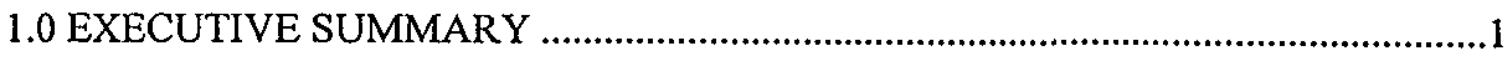

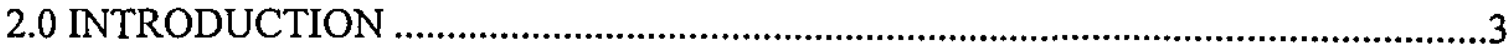

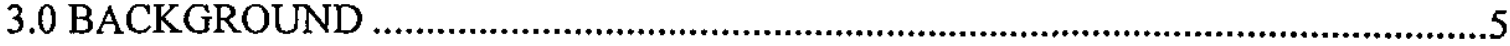

3.1 GEOSIPHON CELL CONCEPT OVERVIEW …................................................

3.1.1 GeoSiphon Cell Description and Configuration..............................................

3.1.2 GeoSiphon Technology Objectives ............................................................

3.1.3 Advantages Over Existing Technologies....................................................8

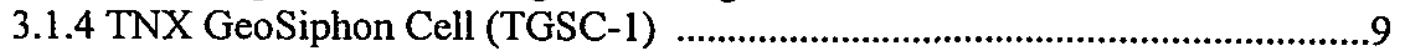

3.2 ZERO VALENT IRON ENHANCED ABIOTIC DEGRADATION

OVERVIEW

3.3 SIPHON TECHNOLOGY OVERVIEW .9

3.4 PHASE II PERMITTING ACTIVITIES OVERVIEW..........................................

4.0 PHASE II SIPHON HYDRAULICS TESTS ………..............................................15

4.1 INITIAL SIPHON LINE CONFIGURATION .................................................15

4.2 PHASE II SIPHON HYDRAULICS TEST DESIGN …….....................................17

4.3 PHASE II SIPHON HYDRAULICS TEST RESULTS ........................................18

4.3.1 Initial Siphon Line Configuration Results ...............................................20

4.3.2 Second Siphon Line Configuration Results...............................................21

4.3.3 Third Siphon Line Configuration Results.................................................22

4.3.4 Fourth Siphon Line Configuration Results ................................................24

4.3.5 Siphon Line Size Evaluation Results..........................................................25

4.3.6 Phase II Siphon Hydraulics Test Results Summary .....................................27

4.4 PHASE II SIPHON LINE PRIMING .................................................................

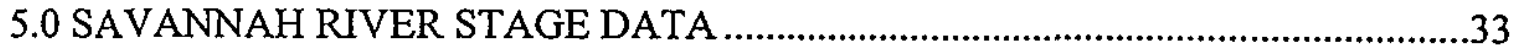

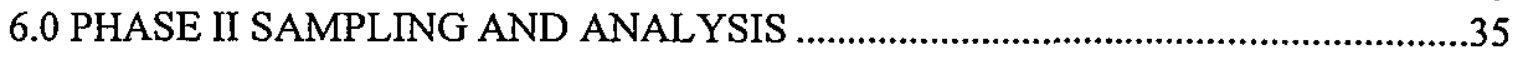

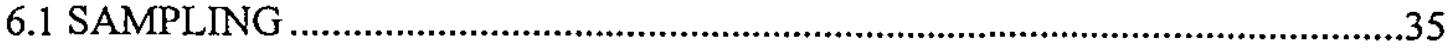

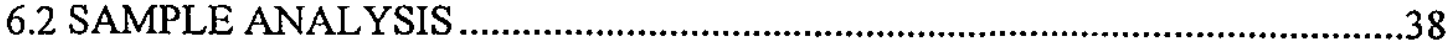

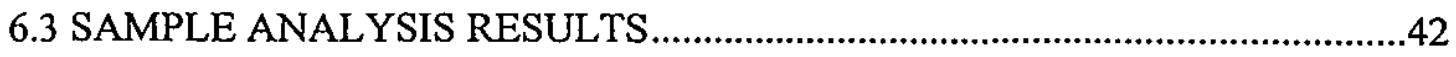

6.3.1 Field/CVOC/Inorganic/Toxicity Water Phase Results ..................................43

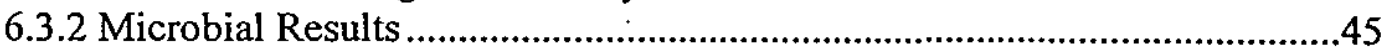

6.3.3 Air Chamber Gas Results..........................................................................47

7.0 CONCLUSIONS AND RECOMMENDATIONS ……...........................................49

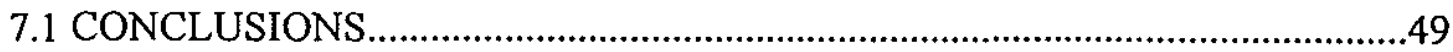

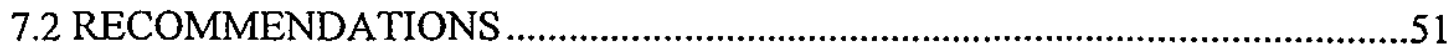

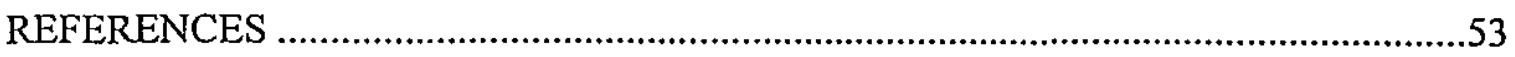

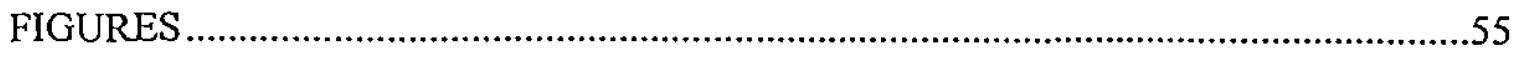




\section{LIST OF TABLES}

Table 1, Pre-Siphon versus Post-Siphon Treatment Cell Configuration Comparison

Table 2, Well TNX-11D / Savannah River Head Differences...............................................16

Table 3, Calculated 1-1/2 Siphon Flow Rates and Velocities..............................................16

Table 4, Wells Construction Details ..............................................................................17

Table 5, Savannah River Gauging Stations ………….....................................................18

Table 6, Siphon Line Configuration Evaluation.................................................................19

Table 7, Flows and Duration between Priming .................................................................20

Table 8, Siphon Line Size Evaluation Summary Results ....................................................27

Table 9, SR-TNX Gauging Station Daily Mean Elevation Data Statistics..........................34

Table 10, Sample Locations..............................................................................................36

Table 11, Pre-operational and Operational Laboratory, Sample Medium,

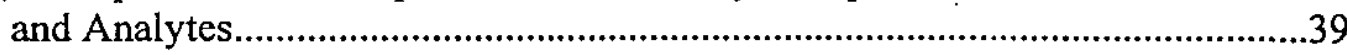

Table 12, Analytical Methods and Sample Bottles.............................................................40

Table 13, Summary Field, CVOC, and Inorganic Data .....................................................44

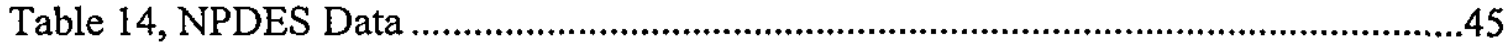

Table 15, Microbial Test Results ....................................................................................46

Table 16, Air Chamber Summary Gas Composition ........................................................48 


\section{LIST OF FIGURES}

Figure 1, GeoSiphon Cell (Pre-Siphon Treatment Cell Configuration) ............................56

Figure 2, GeoSiphon Cell (Post-Siphon Treatment Cell Configuration)............................57

Figure 3, TGSC-1 Location Map ……....................................................................58

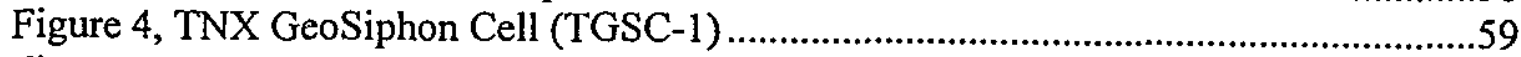

Figure 5, TNX GeoSiphon Cell SS Sample Tube Locations \& Designations.....................60

Figure 6, TGSC-1 Phase II Flows and Water Elevations (through 9/4/98) ......................61

Figure 7, TGSC-1 Siphon Line Map - Initial 1032-Foot Line............................................62

Figure 8, TGSC-1 Siphon Line Profile - Initial 1032-Foot Line ........................................63

Figure 9, TGSC-1 Phase II Flows and Water Elevations - Initial 1032 Foot Line.............64

Figure 10, TGSC-1 Siphon Flow Rate - Initial 1032-Foot Line......................................65

Figure 11, TGSC-1 Siphon Line Pressure/Vacuum Profile - Initial 1032-Foot Line.........66

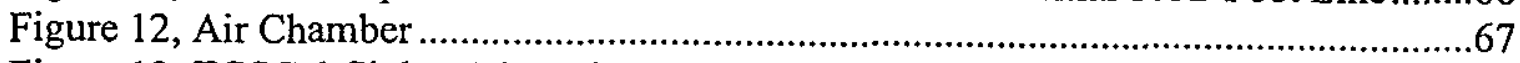

Figure 13, TGSC-1 Siphon Line Map - Air Chamber at TGSC-1 and 1032 Foot Line

Figure 14, TGSC-1 Siphon Line Profile - Air Chamber at TGSC-1 and 1032 Foot Line.

Figure 15, TGSC-1 Phase II Flows and Water Elevations - Air Chamber at TGSC-1 and 1032 Foot Line.

Figure 16, TGSC-1 Siphon Flow Rate - Air Chamber at TGSC-1 and 1032 Foot Line

Figure 17, TGSC-1 Siphon Line Pressure/Vacuum Profile - Air Chamber at TGSC-1 and 1032 Foot Line.

Figure 18, TGSC-1 Siphon Line Map - Air Chamber at X-08 and 1032 Foot Line.

Figure 19, TGSC-1 Siphon Line Profile - Air Chamber at X-08 and 1032 Foot Line.

Figure 20, TGSC-1 Phase II Flows and Water Elevations Air Chamber at X-08 and 1032-Foot Line.

Figure 21, TGSC-1 Siphon Flow Rate - Air Chamber at X-08 and 1032 Foot Line

Figure 22, TGSC-1 Siphon Line Pressure/Vacuum Profile Air Chamber at X-08 and 1032-Foot Line.

Figure 23, TGSC-1 Siphon Line Map - Air Chamber at X-08 and 305 Foot Line

Figure 24, TGSC-1 Siphon Line Profile - Air Chamber at X-08 and 305 Foot Line. 


\section{LIST OF FIGURES (continued)}

Figure 25, TGSC-1 Phase II Flows and Water Elevations -

Air Chamber at X-08 and 305-Foot Line.

Figure 26, TGSC-1 Siphon Flow Rate - Air Chamber at X-08

and 305 Foot Line

Figure 27, TGSC-1 Siphon Line Pressure/Vacuum Profile Air Chamber at X-08 and 305-Foot Line.

Figure 28, SR-Jackson versus SR-TNX Gauging Stations.

Figure 29, Estimated Savannah River Historic Elevation at TNX (from Linear Regression Relationship with SR-Jackson Data)

Figure 30, TGSC-1 and TGSC-2 Siphon Line Map - Steel Air Chambers at X-08 and $\sim 280$ and $\sim 320$ Foot Lines

Figure 31, TGSC-1 Siphon Line Profile - Steel Air Chamber at X-08 and $\sim 280$ Foot Lines

Figure 32, TGSC-2 Siphon Line Profile - Steel Air Chamber at X-08 and $\sim 320$ Foot Lines

Figure 33, TGSC-1 Siphon Flow Rate - Steel Air Chamber at X-08 and $\sim 280$ Foot Lines

Figure 34, TGSC-2 Siphon Flow Rate - Steel Air Chamber at X-08 and 320 Foot Lines

Figure 35, TGSC-1 Siphon Line Pressure/Vacuum Profile - Steel Air Chamber at X-08 and 280 Foot Lines .90

Figure 36, TGSC-2 Siphon Line Pressure/Vacuum Profile - Steel Air Chamber at X-08 and $\sim 320$ Foot Lines 


\section{LIST OF APPENDICES}

Appendix A, Phase II Hand Recorded Hydraulic Data: Appendix A-1, Siphon Line Configuration \# 1 With One Valve At TGSC-1 Crest Appendix A-2, Siphon Line Configuration \# 1 With Two Valves At TGSC-1 Crest Appendix A-3, Siphon Line Configuration \# 2 Appendix A-4, Siphon Line Configuration \# 3 Appendix A-5, Siphon Line Configuration \# 4

Appendix B, SR-Jackson and SR-TNX Gauging Station Linear Regression Relationship Appendix C, SR-TNX Estimated Historic Daily Mean Elevation Appendix D, TNX GeoSiphon Cell Detailed Organic Data Appendix E, TNX GeoSiphon Cell Detailed Field Data Appendix F, TNX GeoSiphon Cell Detailed Inorganic Data Appendix G, TNX GeoSiphon Cell Detailed Gas Analyses 


\title{
LIST OF ACRONYMS
}

\author{
ADS - WSRC SRTC Analytical Development Section \\ A-Tox - acute toxicity \\ BOS - bottom of screen \\ CDCE - cis-1,2-dichloroethylene \\ CMS/FS - Corrective Measures Study / Feasibility Study \\ CT - tetrachloromethane (carbon tetrachloride) \\ CVOCs - chlorinated volatile organic compounds \\ $\mathrm{D}$ - internal pipe diameter in feet \\ DO - dissolved oxygen \\ DOE - Department of Energy \\ Eh - oxidation/reduction potential \\ EMS - WSRC Environmental Monitoring Section \\ EPA - Environmental Protection Agency \\ ERD - WSRC Environmental Restoration Department \\ EST - WSRC SRTC Environmental Sciences and Technology Department \\ ETI - EnviroMetal Technologies, Inc. \\ FITC - fluorescein isothiocyanate \\ $\mathrm{g}$ - acceleration of gravity, $32.2 \mathrm{ft} / \mathrm{s}^{2}$ \\ GC-ECD/FID - gas chromatograph with a electron capture detector and a flame ionization detector \\ GN - gram negative \\ HDPE - high density polyethylene \\ IC Anion - ion chromatography for anions \\ ICP-ES - inductively coupled plasma-emission spectrometry \\ ID - inside diameter \\ IDW - investigative derived waste \\ IWC - instream waste concentration \\ K - Henry's Law Constant \\ LTD - less than detection \\ M\&TE - measurement ànd test equiuipment \\ NA - not analyzed \\ ND - not detected \\ NF - no flow \\ NPDES - National Pollutant Discharge Elimination System \\ OD - outside diameter
}




\section{LIST OF ACRONYMS (continued)}

PCE - tetrachloroethylene

PDWS-MCL - Primary Drinking Water Standard Maximum Contaminant Levels

PVC - polyvinyl chloride

PTYG - peptone-tryptone-yeast-glucose

R\&D - research and development

SCDHEC - South Carolina Department of Health and Environmental Control

SR - Savannah River

SRS - Savannah River Site

SRTC - Savannah River Technology Center

SS - stainless steel

TCE - trichloroethylene

TCM - trichloromethane (chloroform)

TGSC-1 - TNX GeoSiphon Cell \#1

TGSC-2 - TNX GeoSiphon Cell \#2

TNX - SRTC Semi-Works Facility

TOC - top of casing

TOR - top of riser

TOS - top of screen

USGS - United States Geologic Survey

$\mathrm{V}$ - velocity

$\mathrm{VC}$ - chloroethylene (vinyl chloride)

VOA - volatile organic analysis

WSRC - Westinghouse Savannah River Company

WT - water table aquifer 


\subsection{EXECUTIVE SUMMARY}

GeoSiphon Cells (patent pending) are systems to passively induce contaminated groundwater flow through in situ or ex situ permeable treatment media at an accelerated rate by utilizing a siphon between two points of natural hydraulic head difference, without the need for mechanical pumps. The TNX GeoSiphon Cell (TGSC-1) was built in a Pre-Siphon Treatment Cell Configuration. It is essentially a large diameter well, which contains granular cast iron (the treatment media) in place of gravel pack. Contaminated groundwater flow through the granular cast iron in the treatment cell is passively induced by use of a siphon from the cell to the X-08 outfall ditch. The flow is induced by the natural hydraulic head difference between the cell and the X-08 outfall ditch. The granular cast iron reduces the chlorinated volatile organic compounds (CVOCs) to ethane, ethene, methane, and chloride ions. The treated water is subsequently discharged through the X-19 outfall to the X-08 outfall ditch, which flows into the Savannah River.

Testing of four different siphon line configurations was conducted during Phase II testing from June 18, 1998 to September 4, 1998, and a one-day minimum flushing velocity test was conducted on November 13, 1998.

The first three siphon line configurations consisted of approximately 1032 feet of $1-1 / 2$ inch pipe from the cell to the Savannah River. All of these configurations included significant portions of the line laid directly on the ground surface, which resulted in localized high point at various points within that portion of the line. The second and third configurations included the use of an air chamber and the use of engineered grades for approximately 30 percent of the siphon line length. From these configurations, it was determined that degassing and gas entrapment within those portions of the line with localized high points and those portions not influenced by the air chamber resulted in diminishing siphon flow over a matter of hours to essentially zero. Operational improvement was seen with the addition of the air chamber and as more of the line was placed on engineered grades that increased the length of influence of the air chamber.

The fourth siphon line configuration consisted of 305 feet of $1-1 / 2$ inch pipe on a consistent engineered slope, with both the up-gradient (at 1:100 slope) and down-gradient legs (at $22-1 / 2^{0}$ slope) from the air chamber sloping upward toward the air chamber. An initial head differential of approximately 1.43 feet between the cell and the X-08 outfall ditch resulted in an initial recorded flow rate of $2.71 \mathrm{gpm}$. A flow rate of $2.69 \mathrm{gpm}$ was calculated, based upon these initial conditions. The siphon operated continuously over a greater than 6 day period at flow rates varying from 2.23 to $3.98 \mathrm{gpm}$, with an average flow rate of $2.62 \mathrm{gpm}$. Operation of the fourth siphon line configuration resulted in continuous, consistent operation with flow rates consistent with calculated values. Re-priming was not required, however water recharging of the $7-1 / 2$ gallon air chamber was required on a 23 to 25 hour basis. The air chamber can be sized to

$$
\text { Page } 1 \text { of } 92
$$


minimize the frequency of required water recharging. This siphon line configuration with air chamber was able to maintain full siphon line flow by removal of gas bubbles from its entire 305-foot length.

The use of minimum flushing velocity to maintain full flow in the siphon line was evaluated during a one-day test. It was concluded that in order for minimum flushing velocity to potentially be viable as a method of removing gas from the siphon line, in lieu of air chamber usage, line discontinuities and localized high points, which promote bubble accumulation, agglomeration, and potentially entrapment must be eliminated. One continuous pipe without fittings placed on an engineered grade with one crest would probably be the optimal configuration to employ minimum flushing.

The limited analytical data produced during Phase II was consistent with the Phase I data documented in WSRC-TR-98-00032. All effluent tetrachloroethylene, trichloroethylene, carbon tetrachloride, chloroform, and vinyl chloride concentrations were less than the detection limits, and all effluent cis-1,2-dichloroethylene concentrations were less than $3 \mu \mathrm{g} / \mathrm{l}$ (the cis-1,2dichloroethylene limit is $70 \mu \mathrm{g} / \mathrm{l})$. Acute toxicity test results were passing, meaning that the GeoSiphon effluent is not considered toxic. The off-gas collected within the siphon line air chamber consisted primarily of nitrogen and hydrogen with depleted oxygen levels. Based upon the two gas samples collected, this mixture of gas was outside the flammability envelope for both hydrogen and methane (i.e., it is not a flammable gas mixture).

Based upon the favorable results to date, it is recommended that new siphon lines be constructed to engineered grades with air chambers for both TGSC-1 and TGSC-2. The lines should be sized so that the siphon flow rate is approximately that of the cell treatability flow rate as determined in Phase I testing (i.e., approximately $8 \mathrm{gpm}$ ). Additionally a larger air chamber should be provided to lengthen the period of time required between air chamber recharging events (i.e., at least a 200-gallon air chamber). Phase II testing should continue with Phase II Dual Cell Testing. During Phase II Dual Cell Testing, both TGSC-1 and TGSC-2 should be operated, and emphasis should be placed upon the off-gas generation rates and composition, and the zone of influence and capture associated with dual cell operation. Additional minimum flushing velocity testing should also be conducted. 


\subsection{INTRODUCTION}

Phase II testing of the TNX GeoSiphon Cell (TGSC-1) began on June 18, 1998 in order to demonstrate the application of GeoSiphon Cell Technology utilizing zero valent iron enhanced abiotic degradation for the treatment of TNX contaminated groundwater. This activity is classified as an on-site non-baseline research and development (R\&D) performed for the Environmental Restoration Department (ERD). As such it is controlled as a Scoping Activity by Manual 1Q, Procedure QAP 2-3, Control of Research and Development Activities, and the SRTC implementing procedure, Manual L1, Procedure 7.10, Control of Technical Work. In particular this work is controlled by section 5.9 of Manual L1, Procedure 7.10. [WSRC Manual 1Q, Procedure QAP 2-3; WSRC Manual L1, Procedure 7.10; WSRC Manual L14.1, Procedure 2-76]

As the result of predominantly trichloroethylene (TCE) contamination in the TNX Area water table aquifer at the Savannah River Site (SRS), studies into the applicability of zero valent iron enhanced abiotic degradation of chlorinated volatile organic compounds (CVOCs) to the TNX contaminated groundwater have been conducted. Zero valent iron enhanced abiotic degradation of CVOCs is essentially a reductive dechlorination process, which uses granular cast iron as the reducing agent, and produces final reaction products such as methane, ethane, ethene, and chloride ions. [ETI Ref.: 31054.10; SRT-ESS-96-365; WSRC-TR-98-00032]

During 1996, a laboratory study was performed to address this applicability, and it was determined that zero valent iron can treat the TNX CVOC contaminated groundwater to below Primary Drinking Water Standard Maximum Contaminant Levels (PDWS-MCL). The GeoSiphon Cell was conceived as an alternative to pump and treat systems, funnel and gate systems, and/or continuous permeable wall treatment systems for the application of zero valent iron, pursuant to the FY 1996 laboratory study. The first GeoSiphon Cell (TGSC-1) was installed within the TNX flood plain in July 1997. Phase I testing of the GeoSiphon Cell was conducted from August 5, 1997 to December 16, 1997. Phase I testing consisted of pumped flow from the cell to the TNX National Pollutant Discharge Elimination System (NPDES) X-08 outfall, and the creation of steady state conditions so that the in situ field treatment capacity of the cell could be determined. [ETI Ref.: 31054.10; SRT-ESS-96-365; WSRC-TR-98-00032]

Results from Phase I testing indicated that the degradation of TCE, itself, is the limiting compound to treatment below the PDWS-MCLs within the TNX GeoSiphon Cell. The data also indicated that a maximum flow rate of between $7.8 \mathrm{gpm}$ and $8.3 \mathrm{gpm}$ of greater than $200 \mathrm{ppb}$ TCE contaminated groundwater could be treated while maintaining the average discharge TCE concentration below $5 \mu \mathrm{g} / \mathrm{l}$. [WSRC-TR-98-00032]

Based upon the favorable results from Phase I testing, Phase II testing was initiated on June 18,

$$
\text { Page } 3 \text { of } 92
$$


1998. Phase II testing consists of siphon flow from the TNX GeoSiphon Cell (TGSC-1) to the Savannah River through the X-019 Outfall. This phase was designed to determine siphon flow rates, determine the required cell spacing through modeling, and demonstrate the overall concept and functionality of the technology as applied at TNX. The siphon flow rates were determined for the conditions at TNX, and the overall concept and functionality of the technology as applied at TNX was demonstrated. Determination of the required cell spacing through modeling has not been completed; it will be completed during the Phase II Dual Cell Testing through both modeling and testing. This Phase II Final Report documents the Phase II testing conducted from June 18, 1998 through November 13, 1998, and it focuses on the application of the siphon technology as a sub-component of the overall GeoSiphon Cell technology. [Q-TPL-T-00004] 


\subsection{BACKGROUND}

Refer to the TNX GeoSiphon Cell (TGSC-1) Phase I Deployment / Demonstration Final Report (U), WSRC-TR-98-00032, for the following background information not included within this report:

- TNX Area groundwater contamination description

- TNX zero valent iron laboratory study summary

- Phase I permitting activities overview

- TNX GeoSiphon Cell (TGSC-1) installation and as-built conditions

- Detailed Phase I treatability test results

- Phase I pump test results

- Phase I preliminary modeling results

\subsection{GEOSIPHON CELL CONCEPT OVERVIEW}

\subsubsection{GeoSiphon Cell Description and Configurations}

GeoSiphon Cells (patent pending) are systems to passively induce contaminated groundwater flow through in situ or ex situ permeable treatment media at an accelerated rate by utilizing a siphon between two points of natural hydraulic head difference, without the need for mechanical pumps. The upgradient initiation point is within the contaminated aquifer, and the downgradient discharge point can be to a surface water body, the ground surface, or the subsurface. The permeable treatment media utilized in a GeoSiphon Cell can include materials such as but not limited to granular cast iron, activated carbon, ion exchange materials, limestone, zeolites, iron foam, bimetallics, peat, phosphate rock, dolomite, concrete, fly ash, blast furnace slag, sulfur, pyrite, etc. The permeable treatment media can be applied at any point in the passively induced flow. It can be applied as in situ or ex situ. It can be configured to be either permanent or rechargeable. It can be contained within a container or in direct contact with the aquifer materials. [WSRC-TR-98-00032]

There are two basic GeoSiphon Cell configurations (Other configurations are possible):

- Pre-Siphon Treatment Cell Configuration (Figure 1 is an example of such a configuration)

- Post-Siphon Treatment Cell Configuration (Figure 2 is an example of such a configuration) 
The GeoSiphon Cell Pre-Siphon Treatment Cell Configuration of Figure 1 is that of an upgradient, large diameter, in situ treatment cell, which contains the permanent permeable treatment media and passively induces flow by use of a siphon from the cell to a surface stream (or ground surface). The siphon flow is induced by the natural hydraulic head difference between the cell and the surface stream (available head). The passively induced flow draws contaminated groundwater through the treatment cell where the permeable treatment media treats the groundwater. The treated water is subsequently discharged through the siphon to the surface stream. [WSRC-TR-98-00032]

The GeoSiphon Cell Post-Siphon Treatment Cell Configuration of Figure 2 is that of a recovery well connected by siphon to a downgradient, surface assessable, rechargeable, permeable treatment media cell. The siphon flow is induced by the natural hydraulic head difference between the recovery well and the cell (available head). The passively induced flow draws contaminated groundwater through the recovery well, then through the siphon line, and finally to the treatment cell where the permeable treatment media treats the groundwater. The treated water is subsequently discharged to the ground surface or surface water.

Table 1 provides a comparison of the Pre-Siphon Treatment Cell Configuration of Figure 1 with the Post-Siphon Treatment Cell Configuration of Figure 2. Topography and other site conditions may dictate the configuration most appropriate for implementation. The potential minimization of total head loss is the primary advantage associated with the Figure 1 Pre-Siphon Treatment Cell Configuration. Minimization of degassing concerns, more efficient use of the iron mass, and ability to fairly easily regenerate or replace the media are the primary advantages associated with the Figure 2 Post-Siphon Treatment Cell Configuration. 
Table 1

Pre-Siphon versus Post-Siphon Treatment Cell Configuration Comparison

\begin{tabular}{|c|c|c||}
\hline Item & $\begin{array}{c}\text { Pre-Siphon Treatment Cell } \\
\text { Configuration of Figure 1 }\end{array}$ & $\begin{array}{c}\text { Post-Siphon Treatment Cell } \\
\text { Configuration of Figure 2 }\end{array}$ \\
\hline $\begin{array}{c}\text { Treatment cell } \\
\text { location }\end{array}$ & Up-gradient of siphon & Down-gradient of siphon \\
\hline $\begin{array}{c}\text { Siphon line } \\
\text { degassing }\end{array}$ & $\begin{array}{c}\text { Potential for the degassing of other } \\
\text { gases in addition to nitrogen, } \\
\text { oxygen, and carbon dioxide must be } \\
\text { considered based upon the treatment } \\
\text { media chemistry }\end{array}$ & $\begin{array}{c}\text { Potential for nitrogen, oxygen, and } \\
\text { carbon dioxide degassing }\end{array}$ \\
$\begin{array}{c}\text { Treatment cell } \\
\text { influent } \\
\text { concentrations }\end{array}$ & $\begin{array}{c}\text { Variable and dependent upon } \\
\text { formation contaminant stratification } \\
\text { or profile }\end{array}$ & $\begin{array}{c}\text { Averaged formation contaminant } \\
\text { concentration; therefore more } \\
\text { efficient use of the iron mass is } \\
\text { made }\end{array}$ \\
\hline $\begin{array}{c}\text { Media } \\
\text { regeneration or } \\
\text { replacement }\end{array}$ & $\begin{array}{c}\text { Acid regeneration possible; media } \\
\text { removal and replacement may not } \\
\text { be possible }\end{array}$ & $\begin{array}{c}\text { Acid regeneration possible and easy } \\
\text { to control; media removal and } \\
\text { replacement possible }\end{array}$ \\
\hline $\begin{array}{c}\text { System head } \\
\text { loss }\end{array}$ & $\begin{array}{c}\text { Head loss occurs within the } \\
\text { treatment cell, as a well loss, and the } \\
\text { siphon line }\end{array}$ & $\begin{array}{c}\text { Head loss occurs within the siphon } \\
\text { extraction well or trench, as a well } \\
\text { loss, the siphon line, and the } \\
\text { treatment cell; therefore may have } \\
\text { more total head loss associated with } \\
\text { this configuration }\end{array}$ \\
\hline
\end{tabular}

\subsubsection{GeoSiphon Technology Objectives}

The objectives of the GeoSiphon technology are as follows:

- Provide a method to apply any permeable treatment media to the remediation of contaminated groundwater.

- Provide for the remediation of any type of contaminant for which a permeable treatment media is available.

- Provide the passive movement of groundwater through the permeable treatment media.

- Provide a method to accelerate flow through the permeable treatment media over the natural groundwater flow conditions.

- Provide for the in situ or ex situ remediation of contaminated groundwater. 
- To utilize the existing natural head differences between two points to drive an accelerated, passive flow of contaminated groundwater through a permeable treatment media by use of siphon flow without the need for mechanical pumps.

\subsubsection{Advantages Over Existing Technologies}

The GeoSiphon Cell is basically an alternative to pump and treat systems, funnel and gate systems, and/or continuous permeable wall treatment systems. Groundwater pump and treat systems consist of recovery wells which extract contaminated groundwater from the subsurface and above grade treatment systems. Due to slow contaminant dissolution and/or migration, groundwater pump and treat systems often require extended treatment periods (i.e. $10 \mathrm{~s}$ to $100 \mathrm{~s}$ of years) to reduce the contaminant levels to regulatory standards. These extended periods of operation can require significant energy costs, operating and maintenance costs, and monitoring costs. [WSRC-TR-98-00032]

In order to overcome the high operating and maintenance costs of pump and treat systems, funnel and gate and continuous permeable wall treatment systems (together labeled as permeable reactive barriers) have been proposed and implemented. Funnel and gate systems consist of impermeable barriers, which funnel the contaminated groundwater through a permeable treatment gate consisting of permeable treatment media. Continuous permeable wall systems consist of a continuous bed of permeable treatment media, which intersects the entire plume perpendicular to the direction of flow. These are passive, in situ systems, which can take significantly longer than pump and treat systems to achieve regulatory clean up standards, since these systems rely only on the natural groundwater flow rates for transport of the contaminants to the permeable treatment media. However these systems achieve remediation with minimal operating and maintenance costs relative to pump and treat. [WSRC-TR-98-00032]

The GeoSiphon Cell for the remediation of contaminated groundwater is an innovative and unique alternative to current technologies (pump and treat, funnel and gate, continuous permeable wall). GeoSiphon Cells have many of the advantages of the current technologies without most of the disadvantages. GeoSiphon Cells utilize natural hydraulic driving forces to induce accelerated flow rates (greater than natural) for remediation similar to conventional pump and treat systems, but improve upon them through passive operation (no external power GeoSiphon Cells is similar to funnel and gate and continuous permeable wall treatment systems. However, construction costs may be lower, less land disturbance should occur, existing foundation installation and/or well drilling techniques can be used, flow greater than the natural groundwater flow can be induced (that is, accelerate clean up), the potential for formation pluggage due to mineral precipitation should be reduced (if discharged to a surface water body, or the ground surface), and media replacement or regeneration cost may be lower. [WSRC-TR98-00032] 
GeoSiphon Cells can minimize the operating and maintenance costs associated with pump and treat systems, and they potentially accelerate clean up as compared to funnel and gate and continuous permeable wall treatment systems. [WSRC-TR-98-00032]

\subsubsection{TNX GeoSiphon Cell (TGSC-1)}

The TNX GeoSiphon Cell (TGSC-1) is essentially a large diameter well, which contains granular cast iron (the treatment media) in place of gravel pack. It was installed utilizing an auger and removable caisson within the TNX flood plain from July 7, 1997 to July 17, 1997. Figures 3, 4, and 5 provide the location and as-built conditions of TGSC-1 (see WSRC-TR-98-00032 section 4.0 and appendix A for details concerning the installation and as-built conditions of TGSC-1). Contaminated groundwater flow through the granular cast iron in the treatment cell is passively induced by use of a siphon from the cell to the Savannah River or X-08 outfall ditch. The flow is induced by the natural hydraulic head difference between the cell and the Savannah River or X08 outfall ditch. The granular cast iron reduces the chlorinated volatile organic compounds (CVOCs) to ethane, ethene, methane, and chloride ions (see section 3.2 for a description of zero valent iron enhanced abiotic degradation). The treated water is subsequently discharged through the X-19 outfall to the X-08 outfall ditch, which flows into the Savannah River. [WSRC-TR-9800032]

\subsection{ZERO VALENT IRON ENHANCED ABIOTIC DEGRADATION OVERVIEW}

Zero valent iron enhanced abiotic degradation of chlorinated volatile organic compounds (CVOCs) is essentially a reductive dechlorination process, which uses granular cast iron as the reducing agent, and produces final reaction products such as ethane, ethene, and chloride ions in the degradation of trichloroethylene (TCE). During this treatment process, the corrosion of iron by water dominates the chemical processes. The corrosion of iron by water results in ferrous ion generation, hydroxyl ion generation, and hydrogen gas generation. This results in a decrease in Eh (oxidation/reduction potential; that is, reducing conditions are produced) and an increase in $\mathrm{pH}$. This treatment media has been developed and patented by the University of Waterloo and is marketed by EnviroMetal Technologies, Inc. All that is required for treatment of CVOC contaminated groundwater using this technology is to provide contact time between the contaminated groundwater and the granular cast iron. The exact pathway(s) for this reductive dechlorination process has not yet been fully determined. However it appears that it is a surface activated reaction, which may require the adsorption of the CVOCs onto specific active surface sites on the iron. It has been postulated that the following two competing degradation pathways may exist:

- Step-wise dechlorination pathway

- Multiple dechlorination pathway 
[Gillham and O'Hannesin, 1994; ETI Ref.: 31054.10; Tratnyek, et. al., 1997; EPA/600/F-97/008; O'Hannesin and Gillham, 1998]

Following the step-wise dechlorination pathway, it is postulated that the iron is oxidized and CVOCs are reduced by the removal of the chlorine and replacement with hydrogen in a stepwise fashion. In this pathway TCE degrades to cis-1,2-dichloroethylene (CDCE), $\mathrm{CDCE}$ in turn degrades to vinyl chloride (VC), and VC subsequently degrades to ethene and ethane. Following the multiple dechlorination pathway ( $\beta$-elimination through chloroacetylene/acetylene), it is postulated that the iron is oxidized, TCE degrades to chloroacetylene with the removal of two chlorines (reduced), chloroacetylene degrades to acetylene with the removal of one chlorine (reduced), and acetylene finally degrades to ethene and ethane. The chloroacetylene and acetylene under these conditions are very unstable and degrade rapidly, therefore it is difficult to monitor their presence. [Gillham and O'Hannesin, 1994; ETI Ref.: 31054.10; Tratnyek, et. al., 1997; EPA/600/F-97/008; O'Hannesin and Gillham, 1998]

Regardless of the exact dechlorination pathway followed, the following are the basic final reactions that occur, during zero valent iron enhanced abiotic degradation of TCE utilizing granular cast iron:

- Corrosion of iron by water and subsequent ferrous ion generation, hydroxyl ion generation, and hydrogen gas generation:

$$
\mathrm{Fe}^{\mathrm{o}}+2 \mathrm{H}_{2} \mathrm{O}=\mathrm{Fe}^{+2}+2 \mathrm{OH}^{-}+\mathrm{H}_{2}(\mathrm{~g})
$$

- Corrosion of iron by oxygen which results in dissolved oxygen gas depletion:

$$
2 \mathrm{Fe}^{\mathrm{o}}+\mathrm{O}_{2} \text { (aq.) }+4 \mathrm{H}^{+}=2 \mathrm{Fe}^{+2}+2 \mathrm{H}_{2} \mathrm{O}
$$

- Reduction of TCE to ethane and ethene and subsequent ferrous and chloride ion production:

$$
2 \mathrm{Fe}^{\mathrm{O}}+\mathrm{C}_{2} \mathrm{HCl}_{3}+5 \mathrm{H}^{+}=2 \mathrm{Fe}^{+2}+\mathrm{C}_{2} \mathrm{H}_{6}+3 \mathrm{Cl}^{-}
$$

(ethane represents ethane and ethene)

[Gillham and O'Hannesin, 1994; ETI Ref.: 31054.10; Tratnyek, et. al., 1997; EPAV600/F-97/008; O'Hannesin'and' Gillham, $=1998]$

Results from Phase $l$ testing indicate that the degradation of TCE, itself, is the limiting compound to treatment below the PDWS-MCLs within the TNX GeoSiphon Cell. Little, if any, CDCE as a TCE intermediate degradation product was produced during Phase I testing. Additionally no vinyl chloride (VC) was detected during Phase I testing. Based upon this lack of cDCE and VC intermediate degradation product production, it appears that degradation within TGSC-1 may be predominately following the postulated multiple dechlorination pathway $(\beta-$ 
elimination through chloroacetylene/acetylene) as discussed above. However, the following could also be the explanation for the lack of observed $\mathrm{CDCE}$ and VC:

- The spacing of the sampling ports may not have been frequent enough to observe the production and subsequent degradation of the $\mathrm{CDCE}$ and $\mathrm{VC}$. The first order rate constants associated with $\mathrm{CDCE}$ and VC are typically significantly less than that of TCE. Since significant TCE was detected in 5 of the sample ports and $\mathrm{CDCE}$ and VC have lower first order rate constants, it should be anticipated that production of $\mathrm{CDCE}$ and VC through step-wise dechlorination would have been detected within the sample ports.

- The stepwise dechlorination could occur multiple times on the iron surface prior to transport of the organic back into bulk solution, where it could be measured.

The Phase I data also indicated that a maximum flow rate of between $7.8 \mathrm{gpm}$ and $8.3 \mathrm{gpm}$ of greater than 200 ppb TCE contaminated groundwater could be treated within the TNX GeoSiphon Cell (TGSC-1) while maintaining the average discharge TCE concentration below 5 $\mu \mathrm{g} / \mathrm{l}$. [WSRC-TR-98-00032]

\subsection{SIPHON TECHNOLOGY OVERVIEW}

A siphon is a closed conduit which passively (i.e., no power input) conveys liquid from a point of higher hydraulic head to one of lower head after raising it to a higher intermediate elevation which is at sub-atmospheric conditions (negative pressures). In other words a siphon is essentially a passive vacuum pump. A siphon has a maximum theoretical lift of 34 feet (equivalent to atmospheric pressure); however it has a maximum practical lift of 25 feet due to the vapor pressure of water and friction head loss. [Gibson, 1961; WSRC-TR-98-00032]

Siphons require priming (initial filling of line) to initiate flow. This can be accomplished by gravity filling from the line high point (crest) with the inlet and outlet valved off or by use of a vacuum pump at the crest with the inlet and outlet submerged and opened. After priming, the siphon will passively convey liquid from the point of higher hydraulic head to the one of lower head indefinitely so long as the head differential is maintained and the prime is not lost. [Gibson, 1961; Loitz, et. al., 1990; WSRC-TR-98-00032]

Accumulation of air can break the siphon; however this can be avoided by employing the following:

- Use of submerged inlets and outlets to prevent air from being drawn into the siphon

- Maintenance of full flow in the siphon by one or both of the following methods:

- Maintenance of the minimum flushing velocity required to transport gases, which have degassed from the liquid, out the end of the siphon 
- Use of air chambers at the siphon crest to remove gases from the siphon, which have degassed from the liquid

The following are equations to determine the required minimum flushing velocity for the transport of large air bubbles out the end of the siphon as determined from laboratory and largescale tests, respectively, as reported within the literature:

- $\mathrm{V}=0.31$ (SQRT $(\mathrm{gD}))$ (laboratory)

$-\mathrm{V}=0.58(\mathrm{SQRT}(\mathrm{gD}))$ (large scale)

$\mathrm{V}=$ velocity $\mathrm{g}=32.2 \mathrm{ft} / \mathrm{s}^{2} ; \mathrm{D}=$ internal pipe diameter in feet

[Gibson, 1961; Mathur, 1990]

An air chamber is essentially an accumulation high point for gases, which degas from the water within the siphon line. The air chamber allows accumulation of the gas within the chamber itself while preventing accumulation within the siphon line. Air chambers are located above the siphon line at the line high point (crest) and are connected to the siphon line itself. The air chamber is initially filled with water during priming of the siphon line. As the system operates degassing occurs, and the buoyancy of the gas and/or the flow of water transport the gas to the air chamber, where the gas accumulates and displaces the water within the air chamber. The gas within the air chamber must be evacuated and replaced with water on a periodic basis in order to maintain the siphon line free of accumulated gas. The air chamber can be sized to minimize the frequency of re-filling. [Gibson, 1961; Mathur, 1990]

\subsection{PHASE II PERMITTING ACTIVITIES OVERVIEW}

The primary permitting through the South Carolina Department of Health and Environmental Control (SCDHEC) and the Environmental Protection Agency (EPA) associated with the TNX GeoSiphon Cell Phase II Demonstration included the following permits:

- Approval of the treatment cell installation as a well (SCDHEC).

- Modification of the SRS National Pollutant Discharge Elimination System (NPDES)

Permit \# SC0000175 for discharge of the treated groundwater to the Savannah River (SCDHEC).

- Approval of siphon line installation and system operation through Industrial Wastewater Construction and Operating Permits, respectively (SCDHEC).

- Issuance of a Treatability Study Report (SCDHEC and EPA). 
The following is a correspondence summary for the SCDHEC and EPA permitting outlined above for the TNX GeoSiphon Cell Phase II Demonstration:

- Letter, Donald L Siron to J. W. Cook, dated January 9, 1997, transmitted Approval \# SF-97-0002 for the installation of two (2) GeoSiphon Cells designated TGSC-1 and TGSC-2.

- Letter, Harriet H. Gilkerson to J. W. Cook, dated March 14, 1997, accepting final TNX GeoSiphon Cell design as deviating minimally from the initial submittal; therefore changes to the original approval dated January 9, 1997 (Siron to Cook) were not required. - Letter, Brian T. Hennessey to K. A. Collinsworth and J. L. Crane, dated June 26, 1997, outlining agreement that the GeoSiphon Cell demonstration would be conducted in the TNX area and that this technology will be discussed in the CMS/FS for the TNX Area Operable Unit and the result of the test will be documented in a separate Treatability Study Report.

- Letter, Melinda G. Vickers to M. D. Dukes, dated July 23, 1997, provided conceptual approval of the TNX GeoSiphon Cell Preliminary Engineering Report and determined that this facility would not require a certified wastewater operator.

- Letter, Harriet H. Gilkerson to J. W. Cook, dated August 25, 1997, provided approval for installation of a replacement sampling tube TGSC-1A for the TNX GeoSiphon Cell (TGSC-1A).

- Letter, Marion F. Sadler to M. D. Dukes, dated January 5, 1998, provided modifications to NPDES Permit \# SC0000175 for the Savannah River Site, and it included addition of Outfall X-019 for the discharge of treated groundwater from the TNX GeoSiphon Cell(s). - Letter, Marion F. Sadler to J. W. Cook, dated January 9, 1998, transmitted Construction Permit No. 18234-IW for the SRS/TNX GeoSiphon Phase II.

- Letter, Betsy Malpass to Westinghouse Savannah River Company, dated June 11, 1998, provided a partial permit to operate the SRS/TNX GeoSiphon Cell Phase II in accordance with Construction Permit No 18234-IW.

- Letter, Melinda G. Vickers to J. A. Lintern, dated August 26, 1998, provided approval for a temporary siphon line reconfiguration for the SRS/TNX GeoSiphon Cell Phase II.

- Letter, Byron M. Amick to J. W. Cook, dated October 6, 1998, provided approval for a siphon line reconfiguration for the SRS/TNX GeoSiphon Cell Phase II.

- Letter, Brian T. Hennessey to K. A. Collinsworth and J. L. Crane, dated November 3, 1998, providing the schedule for the GeoSiphon Cell Phase II Demonstration Treatability Study Report. 
Left Blank Intentionally 


\subsection{PHASE II SIPHON HYDRAULICS TESTS}

\subsection{INITIAL SIPHON LINE CONFIGURATION}

The siphon line was initially sized, designed, and installed per the following criteria:

- To maintain a submerged inlet and outlet to prevent air from being drawn into the siphon

- To maintain full flow in the siphon by maintenance of the minimum flushing velocity required to transport gases, which have degassed from the liquid, out the end of the siphon (see section 3.3)

- To utilize the full head differential available between the cell (TGSC-1) and the - Savannah River

- To produce a siphon flow rate equivalent to the anticipated treatment capacity of TGSC-1

The TNX GeoSiphon Cell Phase II Industrial Wastewater Treatment Facility Construction Permit Application Package Calculation Number GCD-4 provided sizing of the siphon line based upon the criteria outline above. Table 2 provides same day head differences between monitoring well TNX-11D and the Savannah River utilized in the calculation. TNX-11D water levels were utilized to represent the water levels anticipated for TGSC-1. TNX-11D is approximately 50foot side gradient to TGSC-1, and it has significant water level data over time. Table 3 presents the calculated flow rate and calculated velocity through a $1-1 / 2$ inch high density polyethylene (HDPE) siphon line for the minimum, average, and maximum heads as presented in Table 2. Table 3 also presents the minimum flushing velocity required to transport gases out the end of the siphon per the equations presented in section 3.3 for comparison to the calculated velocities in the siphon line. Based upon the calculated siphon line velocity and the minimum flushing velocity to maintain full flow, the 1-1/2 inch HDPE siphon should have been able to transport gases that degas from the treated water out the end of the siphon for head differentials of greater than 2.9 feet. Head differentials of 2.9 feet or greater produce flows of $4.1 \mathrm{gpm}$ or greater, which based upon Table 2 should be exceeded most of the time. [Gibson, 1961; Mathur, 1990; TNX GeoSiphon Cell Phase II Industrial Wastewater Treatment Facility Construction Permit Application Package] 
Table 2

Well TNX-11D/Savannah River Head Differences

\begin{tabular}{|c|c|c|c|}
\hline Date & $\begin{array}{c}\text { TNX-11D } \\
\text { Elevation } \\
\text { (ft-msl) }\end{array}$ & $\begin{array}{c}\text { Savannah } \\
\text { River } \\
\text { Elevation } \\
\text { (ft-msl) }\end{array}$ & $\begin{array}{c}\text { Head } \\
\text { Difference } \\
(\mathrm{ft})\end{array}$ \\
\hline $9 / 17 / 91$ & 93.22 & 84.82 & 8.80 \\
\hline $11 / 15 / 91$ & 93.64 & 85.05 & 8.59 \\
\hline $12 / 17 / 91$ & 93.52 & 84.77 & 8.75 \\
\hline $1 / 16 / 92$ & 93.82 & 86.99 & 6.83 \\
\hline $2 / 19 / 92$ & 94.08 & 86.35 & 7.73 \\
\hline $4 / 15 / 92$ & 93.92 & 84.59 & 9.33 \\
\hline $6 / 16 / 92$ & 93.88 & 85.65 & 8.23 \\
\hline $7 / 17 / 92$ & 93.68 & 84.00 & 9.68 \\
\hline $11 / 16 / 92$ & 94.24 & 90.12 & 4.12 \\
\hline $10 / 14 / 93$ & 92.63 & 82.53 & 10.10 \\
\hline $3 / 14 / 93$ & 94.14 & 84.68 & 9.46 \\
\hline $7 / 11 / 94$ & 94.80 & 92.52 & 2.28 \\
\hline $11 / 14 / 96$ & 93.17 & 86.33 & 6.85 \\
\hline $12 / 10 / 96$ & 93.13 & 86.27 & 6.86 \\
\hline Average & 93.73 & 86.05 & 7.69 \\
\hline
\end{tabular}

Table 3

Calculated 1-1/2 Siphon Flow Rates and Velocities

\begin{tabular}{||c|c|c|c|c|c||}
\hline $\begin{array}{c}\text { Head } \\
\text { Condition }\end{array}$ & $\begin{array}{c}\text { Head } \\
\text { Difference } \\
(\mathrm{ft})\end{array}$ & $\begin{array}{c}\text { Flow } \\
\text { Rate } \\
(\mathrm{gpm})\end{array}$ & $\begin{array}{c}\text { Flow } \\
\text { Velocity } \\
(\mathrm{ft} / \mathrm{s})\end{array}$ & $\begin{array}{c}\text { Minimum } \\
\text { Flushing } \\
\text { Velocity }{ }^{1} \\
(\mathrm{ft} / \mathrm{s})\end{array}$ & $\begin{array}{c}\text { Minimum } \\
\text { Flushing } \\
\text { Velocity } \\
(\mathrm{ft} / \mathrm{s})\end{array}$ \\
\hline Minimum & 2 & 3.2 & 0.5 & 0.64 & 1.19 \\
\hline Low & 2.9 & 4.1 & 0.64 & 0.64 & 1.19 \\
\hline Average & 7.69 & 7.9 & 1.25 & 0.64 & 1.19 \\
\hline Maximum & 10 & 9.5 & 1.49 & 0.64 & 1.19 \\
\hline
\end{tabular}

$\mathrm{V}=0.31$ (SQRT (gD)) (laboratory)

${ }^{2} \mathrm{~V}=0.58$ (SQRT (gD)) (large scale)

$\mathrm{V}=$ velocity; $\mathrm{g}=32.2 \mathrm{ft} / \mathrm{s}^{2} ; \mathrm{D}=$ internal pipe diameter in feet 
Based upon the above criteria and calculations, the initial siphon line, consisting of approximately 1032 feet of $1-1 / 2$ inch pipe laid directly on the ground surface from the cell to the river without an air chamber, was installed (see Figures 6 and 7 for the initial siphon line map and profile, respectively).

\subsection{PHASE II SIPHON HYDRAULICS TEST DESIGN}

Phase II of the demonstration was designed to induce flow through the TNX GeoSiphon Cell by siphon, and to discharged the treated water directly to the Savannah River through the TNX NPDES X-19 outfall. The primary parameters monitored during Phase II, in order to evaluate the siphon technology aspects of the GeoSiphon Cell, were flow rates and head differential. Siphon flow rates and water levels from the TNX GeoSiphon Cell (TGSC-1), monitor well TNX-9D, and the Savannah River were monitored. Figure 3 is a well location map, which shows the relationship between TGSC-1, TNX-9D, the X-08 outfall ditch, and the Savannah River. Monitor well TNX-9D is approximately 360 feet side gradient of TGSC-1, and TGSC-1 operation is assumed to have minimal impact on TNX-9D water levels based upon the results from Phase I testing. Therefore, the difference in water elevations between TGSC-1 and TNX-9D during operation can be essentially assumed to represent the drawdown in TGSC-1 associated with its operation. Table 4 provides the well construction details and distance from TGSC-1 for TGSC-1, TNX-9D, and TNX-11D (TNX11D was utilized in the flow calculations of section 4.1). Table 5 provides details concerning the Savannah River gauging stations, which were utilized. [WSRC-TR-98-00032; Q-TPL-T-00004]

\section{Table 4}

Wells Construction Details

\begin{tabular}{|c|c|c|c|c|c|c|c|c|}
\hline$\overline{\overline{\text { Well }}}$ & Coordinates & \multicolumn{4}{|c|}{ Elevation (ft-msl) } & Casing & \multirow[t]{2}{*}{ Aquifer } & \multirow{2}{*}{$\begin{array}{l}\text { Distance } \\
\text { to TGSC-1 }\end{array}$} \\
\hline Id & (ft) & TOR & TOC & TOS & BOS & Diameter & & \\
\hline TGSC-1 & $\begin{array}{l}\text { N71150.24 } \\
\text { E16176.21 }\end{array}$ & - & 98.13 & 90.9 & 76.9 & $12 "$ & WT & $0^{\prime}$ \\
\hline TNX-9D & $\begin{array}{l}\text { N70791.4 } \\
\text { E16145.8 }\end{array}$ & 101.9 & 101.7 & 95.4 & 75.4 & 4" & $\overline{\mathrm{WT}}$ & $360.2^{\prime}$ \\
\hline TNX-11D & $\begin{array}{l}\text { N71199.3 } \\
\text { E16165.5 }\end{array}$ & 100.3 & 99.8 & 93.2 & 73.2 & 4" & WT & $50.2^{\prime}$ \\
\hline
\end{tabular}

Notes:

$\mathrm{TOR}=$ top of riser; TOC $=$ top of casing; $\mathrm{TOS}=$ top of screen; $\mathrm{BOS}=$ bottom of screen; $\mathrm{WT}=$ water table aquifer 
Table 5

Savannah River Gauging Stations

\begin{tabular}{|l|l|l|l||}
\hline Station & Operator & Location & $\begin{array}{l}\text { Elevation } \\
\text { (ft-msl) }\end{array}$ \\
\hline SR-TNX & EST & N71647.14 & 94.95 (platform) \\
& & E15668.48 & 96.70 (TOC) \\
\hline SR-Jackson & USGS & N74321.83 & 77.00 \\
& & E16447.89 & \\
\hline
\end{tabular}

The following equipment was utilized in the test:

- Two pressure transducers and two Insitu data loggers were utilized to monitor the water levels within TGSC-1 and TNX-9D

- One pressure transducer and one Campbell data logger with an internal clock were utilized to monitor the Savannah River water level at the SR-TNX gauging station

- One Panametric Ultrasonic Flow Meter installed on the upward leg of the PVC discharge piping out of the TGSC-1 12 inch casing and one Campbell data logger with an internal clock were utilized to monitor the flow in the siphon line

- One electric water level tape

Water level measurements were taken in each well (TGSC-1 and TNX-9D) and at the Savannah River (SR-TNX gauging station) every 60 minutes during the test with the pressure transducers and data loggers. Flow measurements were taken every 30 minutes during the test with the flow meter and data logger. Electric water level tape measurements (hand measurement) of selected wells and of the Savannah River at the SR-TNX gauging station were taken at irregular intervals during the test. Flow readings from the Panametric Ultrasonic Flow Meter were also taken by hand at irregular intervals during the test. [Q-TPL-T-00004]

\subsection{PHASE II SIPHON HYDRAULICS TEST RESULTS}

Testing of four different siphon line configurations was conducted during Phase II testing. The siphon line configuration testing began on June 18,1998 and was completed on September 4, 1998. Table 6 lists the dates of testing for each configuration, provides a description of each configuration, and lists the Figures associated with each configuration. Table 7 provides a summary of operation duration between priming events and associated flow rates and associated rate of flow rate decline associated with operation of each siphon line configuration, based upon the hand recorded data (Appendix A). Figure 6 provides a summary graph of the flow rates through the siphon line and the water elevations of TGSC-1 (extraction well) and well TNX-9D (side gradient monitoring well assumed to be minimally impacted by the extraction from TGSC-

$$
\text { Page } 18 \text { of } 92
$$


1) for each siphon line configuration evaluated. Figure 6 along with Table 7 demonstrate the progression of improvement with each successive configuration, with the fourth configuration providing complete removal of gas and subsequent continuous operation. Detailed results for each configuration are presented in the sections that follow.

Additionally, on November 13, 1998 a one-day test was conducted to evaluate the ability to utilize a minimum flushing velocity to sweep gas out of the line through smaller diameter tubing without the need for an air chamber. Section 4.3.5 describes this evaluation and its results.

Table 6

Siphon Line Configuration Evaluation

\begin{tabular}{|c|c|c|c|}
\hline $\begin{array}{c}\text { Config. } \\
\#\end{array}$ & $\overline{\text { Date }}$ & Configuration Description & Figures \\
\hline $\begin{array}{c}1 \\
\text { (initial) }\end{array}$ & $\begin{array}{c}6 / 18 / 98 \\
\text { thru } \\
6 / 26 / 98\end{array}$ & $\begin{array}{l}\text { 1) } 1032^{\prime} \text { of } 1-1 / 2 \text { inch siphon line laid directly } \\
\text { on the ground from the cell (TGSC-1) to the X- } \\
08 \text { outfall ditch and down the ditch to the } \\
\text { Savannah River, with no air chamber }\end{array}$ & $\begin{array}{c}7 \\
\text { thru } \\
11\end{array}$ \\
\hline 2 & $\begin{array}{c}8 / 3 / 98 \\
\text { thru } \\
8 / 11 / 98\end{array}$ & $\begin{array}{l}\text { 2) } 1032 \text { of } 1-1 / 2 \text { inch siphon line with a } 1: 100 \\
\text { downward slope from the cell to the X-08 } \\
\text { outfall ditch and laid directly on the ground in } \\
\text { the ditch to the Savannah River, with an air } \\
\text { chamber at the cell }\end{array}$ & $\begin{array}{c}13 \\
\text { thru } \\
17\end{array}$ \\
\hline 3 & $\begin{array}{c}8 / 12 / 98 \\
\text { thru } \\
8 / 27 / 98\end{array}$ & $\begin{array}{l}\text { 3) } 1032^{\prime} \text { of } 1-1 / 2 \text { inch siphon line with a } 1: 100 \\
\text { upward slope from the cell to the } X-08 \text { outfall } \\
\text { ditch, a } \sim 22-1 / 2^{\circ} \text { slope into the ditch, and laid } \\
\text { directly on the ground in the ditch to the } \\
\text { Savannah River, with an air chamber at the } \\
\text { crest adjacent to the X-08 outfall ditch }\end{array}$ & $\begin{array}{c}18 \\
\text { thru } \\
22\end{array}$ \\
\hline 4 & $\begin{array}{c}8 / 27 / 98 \\
\text { thru } \\
9 / 4 / 98\end{array}$ & $\begin{array}{l}\text { 4) } 305^{\prime} \text { of } 1-1 / 2 \text { inch siphon line with a } 1: 100 \\
\text { upward slope from the cell to the X-08 outfall } \\
\text { ditch, a } 22-1 / 2^{\circ} \text { slope into the ditch where the } \\
\text { line terminates in the ditch, with an air chamber } \\
\text { at the crest adjacent to the X- } 08 \text { outfall ditch }\end{array}$ & $\begin{array}{c}23 \\
\text { thru } \\
27\end{array}$ \\
\hline
\end{tabular}


Table 7

Flows and Duration between Priming

\begin{tabular}{|c|c|c|c|c|c|}
\hline \multirow{2}{*}{$\begin{array}{l}\text { Configuration } \\
\text { Number }\end{array}$} & \multirow{2}{*}{$\begin{array}{c}\text { Operation } \\
\text { Duration before } \\
\text { Re-priming } \\
\text { Required }\end{array}$} & \multicolumn{3}{|c|}{ Flow Rates (gpm) } & \multirow{2}{*}{$\begin{array}{l}\text { Rate of } \\
\text { Flow Rate } \\
\text { Decline } \\
(\mathrm{gpm} / \mathrm{hr})\end{array}$} \\
\hline & & Initial & Final & Calculated & \\
\hline$\overline{11}$ & $15 \mathrm{hr}, 55 \mathrm{~min}$ & 7.82 & 0.74 & $\overline{7.78}$ & 0.4448 \\
\hline 1 & $25 \mathrm{hr}, 40 \mathrm{~min}$ & 8.12 & 0.22 & - & 0.3078 \\
\hline$\overline{2}$ & $17 \mathrm{hr}, 50 \mathrm{~min}$ & 4.46 & $\overline{0.4}$ & $\overline{8.08}$ & 0.2277 \\
\hline 2 & $16 \mathrm{hr}, 28 \mathrm{~min}$ & 4.32 & 0.47 & - & 0.2159 \\
\hline 2 & $23 \mathrm{hr}, 49 \mathrm{~min}$ & 5.36 & 0.17 & - & 0.2179 \\
\hline 2 & $21 \mathrm{hr}, 20 \mathrm{~min}$ & 5.68 & 0.27 & - & 0.2536 \\
\hline 3 & $8 \mathrm{hr}, 2 \mathrm{~min}$ & 4.7 & 3.33 & 8.38 & $\overline{0.1705}$ \\
\hline 3 & $14 \mathrm{hr}, 43 \mathrm{~min}$ & 3.29 & 0.17 & - & 0.2120 \\
\hline 3 & $23 \mathrm{hr}, 49 \mathrm{~min}$ & 3.10 & 1.02 & - & 0.0873 \\
\hline 3 & $25 \mathrm{hr}, 35 \mathrm{~min}$ & 3.45 & 1.52 & - & 0.0754 \\
\hline 3 & $17 \mathrm{hr}, 29 \mathrm{~min}$ & 2.37 & 1.44 & - & 0.0532 \\
\hline 4 & $\begin{array}{l}\text { Re-priming was } \\
\text { not required }{ }^{1}\end{array}$ & $2.46-4.85$ & $2.46-4.85$ & $\overline{2.69}$ & $\overline{0}$ \\
\hline
\end{tabular}

Configuration Number 4 was operated 6 days, $4 \mathrm{hr}$, and 42 min prior to shut down. Re-priming was not required during its operation. The 7.5-gallon air chamber had to be refilled on a 23 to 24 hour frequency.

\subsubsection{Initial Siphon Line Configuration Results}

Testing of the initial siphon line configuration (Table 6) began on June 18, 1998 and was completed on June 26,1998 . The initial siphon line configuration consisted of approximately 1032 feet of $1-1 / 2$ inch pipe laid directly on the ground surface from the cell to the Savannah River without an air chamber. The line entirely followed the ups and downs of the topography along its route, which created localized high points at various points in the line. Figures 7 and 8 provide the initial siphon line map and profile, respectively. The siphon line was primed and

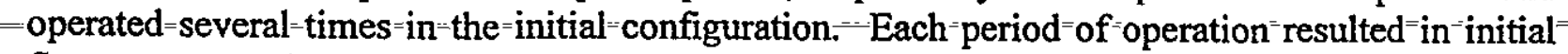
flow rates near the calculated level, based upon the available head, followed by diminishing flow over a matter of hours to essentially zero (see Figure 9). Re-priming was required between each operation. During the June 24 attempt to operate, the available head was 8.52 feet. Based upon this head, a flow rate of $7.78 \mathrm{gpm}$ was calculated (see Figure 10). An initial flow rate of 7.82 gpm was recorded followed by a continuous reduction to $0.74 \mathrm{gpm}$ over an approximately 16hour period. The initial flow rate recorded was essentially identical to that calculated, however the flow rate could not be continuously maintained with this configuration. 
A siphon line by definition operates under vacuum (i.e., below atmospheric pressure). Figure 11 presents the pressure/vacuum profile based upon calculations (see Figure 10) for the initial siphon line configuration. Due to the negative pressures (i.e., vacuum) of the siphon line, the air which was accumulating and breaking the siphon over time could come from either leaks into the siphon line or degassing from the treated water within the siphon line. Both pressure and vacuum tests of the siphon line were performed, and it was demonstrated that siphon line leakage was not the source of the air. Therefore, degassing from the treated water within the siphon line was determined to be the source of the gas. It was determined that due to degassing from the treated water, lack of complete gas transport out of the line, and the subsequent accumulation of the gas within the siphon line, the siphon could not be maintained, and the siphon was eventually broken.

Based upon the results from the initial siphon line configuration, it was decided that an air chamber would be installed to maintain full flow in the siphon line by removing gases that degassed from the siphon line. Figure 12 provides the design of the air chamber utilized.

\subsubsection{Second Siphon Line Configuration Results}

Testing the second siphon line configuration (Table 6) began on August 3, 1998 and was completed on August 11, 1998. The second siphon line configuration also consisted of 1032 feet of 1-1/2 inch siphon line. However, it had a consistent 1:100 downward slope from the cell to the X-08 outfall ditch, and was then laid directly on the ground in the ditch to the Savannah River. That portion of the line within the X-08 outfall ditch followed the ups and downs of the topography along its route within the ditch (it was not a consistent downward slope). The line also had an air chamber (Figure 12) installed at the siphon line crest adjacent to the cell to remove gas from the siphon line. Figures 13 and 14 provide the second siphon line configuration map and profile, respectively. It was thought that the air chamber location at the point of highest vacuum and the consistent 1:100 downward slope from the cell to the X-08 outfall ditch would facilitate gas removal.

The siphon line was primed and operated multiple times in the second configuration. During testing of the second siphon line configuration, a problem with the flow data logger resulted in sporadic recording of flow data. However, water level data for TGSC-1 and TNX-9D were correctly recorded on a separate data logger (see Figure 15). The water level data along with hand recorded flow data (Appendix A) provide sufficient data to describe this phase of testing. Table 6 provides a summary of operation duration between priming events and associated flow rates and associated rate of flow rate decline associated with operation of the second configuration, along with all other siphon line configurations, based upon the hand recorded data (Appendix A). Figure 16 provides the calculated flow rate for the second configuration conditions presented in Table 7. 
Clear PVC Pipe was installed on either side of the air chamber to provide a visual means of evaluating the air chamber's effectiveness. During operation gas bubbles formed on the upstream side of the air chamber could be seen entering the air chamber. However gas bubbles were also seen forming on the down stream side of the air chamber, and the air chamber was capable of capturing gas bubbles formed only a few feet downstream of the air chamber. Any other degassing within the siphon line was not addressed by the air chamber in its location in the crest immediately adjacent to the cell. The buoyancy of gas bubbles formed significantly downstream in the siphon line sloped at 1:100 upward toward the air chamber could not overcome the water flow velocity in the opposite direction in order to travel to the air chamber. Figure 17 presents the pressure/vacuum profile based upon calculations (see Figure 16) for the second siphon line configuration which contributed to the degassing. This lack of capture of all the gas bubbles formed within the siphon line, and the subsequent accumulation of the gas within the siphon line, again resulted in diminishing flow over a matter of hours to essentially zero (see Figure 15 and Table 7). The rate of flow rate decline (gpm/hr in Table 7) associated with the second configuration was less than that of the initial configuration, indicating that the second configuration was an improvement over the first. This also again resulted in the requirement to re-prime between each operation. It should be noted (see Table 7) that the maximum flow rates recorded were significantly less than the calculated rate. This was probably due to gas entrapment within the line, which was not eliminated during priming. Nevertheless, this siphon line configuration did demonstrate that the air chamber was capable of removing the gas bubbles formed up-gradient of the air chamber location.

\subsubsection{Third Siphon Line Configuration Results}

Testing of the third siphon line configuration (Table 6) began on August 12, 1998 and was completed on August 27, 1998. The third siphon line configuration also consisted of $1-1 / 2$ inch 1032 feet of siphon line. However it had a consistent 1:100 upward slope from the cell to the X08 outfall ditch, $a \sim 22-1 / 2^{\circ}$ slope into the ditch, and was then laid directly on the ground in the ditch to the Savannah River. That portion of the line within the X-08 outfall ditch followed the ups and downs of the topography along its route within the ditch (it was not a consistent downward slope). The line also had an air chamber (Figure 12) installed at the siphon line crest adjacent to the X-08 outfall ditch to remove gas from the siphon line. Figures 18 and 19 provide the third siphon line configuration map and profile, respectively. It was thought that the air -chamber-location -at-the-high point adjacent-to-the $X-08$ outfall ditch=would facilitate=gas=bubble removal from that portion of the line between the cell and the line's entrance into the X-08 outfall ditch. It was also thought that significant degassing should not occur within that portion of the line laid directly on the ground in the ditch to the Savannah River, since vacuum levels in this portion of the line were significantly reduced (see Figure 22).

The siphon line was primed and operated several times in the third configuration. As with the initial and second configurations, each period of operation resulted in initial flows, which diminished over a matter of hours to essentially zero (see Figure 20). Re-priming was required 
between each operation. Table 7 provides a summary of operation duration between priming events and associated flow rates and associated rate of flow rate decline associated with operation of the third configuration, along with all other siphon line configurations, based upon the hand recorded data (Appendix A). Figure 21 provides the calculated flow rate for the third configuration conditions presented in Table 7.

Clear PVC Pipe was installed at the cell head and on either side of the air chamber to provide a visual means of evaluating the air chambers effectiveness. During operation gas bubbles could be seen forming at the cell head and on either side of the air chamber. The gas bubbles formed at the cell head could be seen accumulating at the insert fitting between the clear PVC and the subsequent HDPE pipe, until the bubble was large enough to be forced past the fitting. Then the larger bubble would move with the water flow in the direction of the air chamber. Gas bubbles could also be seen moving with the water flow in the clear PVC pipe on the upstream side of the air chamber. When these gas bubbles from the up-gradient side reached the air chamber, they could be seen entering the air chamber and displacing the water in the air chamber. Gas bubbles were also seen forming on the downstream side of the air chamber in the clear PVC, which was at a $\sim 22-12^{\circ}$ downward slope into the X-08 outfall ditch. These downstream gas bubbles could be seen accumulating until a large gas bubble was formed, and its buoyancy overcome the water flow velocity in the opposite direction in order to travel to the air chamber. It appeared that this siphon line configuration with air chamber was able to remove the gas bubbles formed between the cell and where the line entered the X-08 outfall ditch.

Figure 22 presents the pressure/vacuum profile based upon calculations (see Figure 21) for the third siphon line configuration. It had been assumed that minimal degassing would occur within that portion of the line laid directly on the ground in the ditch to the Savannah River, since vacuum levels in this portion of the line were significantly reduced (see Figure 22). However, as with the previous siphon line configurations, diminishing flow over a matter of hours to essentially zero occurred (see Figure 20 and Table 7). The rate of flow rate decline (gpm/hr in Table 7) associated with the third configuration was less than that of both the initial and second configurations, indicating that the third configuration was an improvement over the first two. This diminishing flow rate over time again resulted in the requirement to re-prime between each operation. During re-priming, it was noted that the bulk of the air removed from the siphon line came from that portion of the line within the X-08 outfall ditch. Very little air was removed from that portion of the line up-gradient of the X-08 outfall ditch. This observation indicated that significant degassing and gas entrapment was occurring in that portion of the line within the X-08 outfall ditch. Again it should be noted that the maximum flow rates recorded were significantly less than the calculated flow rate (see Table 7). This was probably due to gas entrapment within that portion of the line within the X-08 outfall ditch, which was not eliminated during priming. 


\subsubsection{Fourth Siphon Line Configuration Results}

Due to the observation that the third siphon line configuration was able to remove the gas bubbles formed between the cell and where the line entered the X-08 outfall ditch, the fourth configuration was tested. Testing of the fourth siphon line configuration (Table 6) began on August 27, 1998 and was completed on September 4, 1998. The fourth siphon line configuration was identical to the third configuration except the last 727 feet of line within the X-08 outfall ditch was cut off and removed. The fourth configuration consisted of 305 feet of $1-1 / 2$ inch siphon line. It had a consistent 1:100 upward slope from the cell to the X-08 outfall ditch, a $\sim 22$ $1 / 2^{0}$ slope into the ditch, and terminated within a sump set below the bottom of the ditch. It also had an air chamber (Figure 12) installed at the siphon line crest adjacent to the X-08 outfall ditch to remove gas from the siphon line. The entire line was on a consistent engineered slope, with both the up-gradient and down-gradient legs from the air chamber sloping upward toward the air chamber. Figures 23 and 24 provide the fourth siphon line configuration map and profile, respectively.

The siphon line was primed once and operated continuously over a greater than 6 day period at flow rates varying from 2.23 to $3.98 \mathrm{gpm}$ with an average $2.62 \mathrm{gpm}$ (see Figure 23 for the data logged flow data). The range of hand recorded flow measurements recorded in Table 7 ranged from 2.46 to $4.85 \mathrm{gpm}$. The difference between the hand and data logged flow data can be explained due to the sporadic nature of the hand measurements versus the continuous set frequency of the data logged measurements. The variations in flow rates over time were due to barometric pressure and rainfall induced watertable fluctuations (see Figure 25). A flow rate of $2.69 \mathrm{gpm}$ was calculated (Figure 26), based upon the initial fourth configuration conditions, and this rate is essentially equivalent to the initial recorded flow rate of $2.71 \mathrm{gpm}$. The head differential available initially to drive the calculated $2.69 \mathrm{gpm}$ was approximately 1.43 feet (i.e. the difference in the groundwater level at the cell and the water level in the X-08 outfall ditch at the end of the siphon line). Approximately 1.2 feet of head was utilized to drive flow through the cell itself, and approximately 0.23 feet of head was utilized to drive flow through the siphon line. Additionally an essentially continuous flow rate was maintained with this configuration, and re-priming was not required. However, the approximately 7.5 gallon air chamber had to be recharged approximately every 23 to 25 hours. It took less than 10 minutes to recharge the air chamber each time. Table 7 provides a summary of operation duration between priming events and associated flow-rates and associated rate of flow-rate decline associated with operation of the fourth configuration, along with all other siphon line configurations, based upon the hand recorded data (Appendix A). Figure 26 provides the calculated flow rate for the third configuration conditions presented in Table 7.

As with the third configuration, clear PVC Pipe was utilized at the cell head and on either side of the air chamber to provide a visual means of evaluating the air chambers effectiveness. During operation gas bubbles could be seen forming at the cell head and on either side of the air chamber. The gas bubbles formed at the cell head could be seen accumulating at the insert

$$
\text { Page } 24 \text { of } 92
$$


fitting between the clear PVC and the subsequent HDPE pipe, until the bubble was large enough to be forced past the fitting. Then the larger bubble would move with the water flow in the direction of the air chamber. Gas bubbles could also be seen moving with the water flow in the clear PVC pipe on the upstream side of the air chamber. When these gas bubbles from the upgradient side reached the air chamber, they could be seen entering the air chamber and displacing the water in the air chamber. Gas bubbles were also seen forming on the downstream side of the air chamber in the clear PVC, which was at a $\sim 22-1 / 2^{0}$ downward slope into the X-08 outfall ditch. These downstream gas bubbles could be seen accumulating until a large gas bubble was formed and its buoyancy overcome the water flow velocity in the opposite direction in order to travel to the air chamber. This siphon line configuration with air chamber was able to remove the gas bubbles formed in its entire 305 -foot length as evidenced by the continuous, consistent operation.

Figure 27 presents the pressure/vacuum profile based upon calculations (see Figure 26) of the fourth siphon line configuration. Although degassing occurred throughout the length of the line, no flow rate decline ( $\mathrm{gpm} / \mathrm{hr}$ in Table 7 ) associated with accumulation of gas within the fourth siphon line configuration was observed.

\subsubsection{Siphon Line Size Evaluation Results}

On November 13, 1998 a one-day test was conducted to evaluate the ability to utilize a minimum flushing velocity to sweep gas out of the line through smaller diameter tubing without the need for an air chamber (see section 3.3 for a more detailed discussion of minimum flushing velocity). The fourth siphon line configuration was modified by removing the air chamber and associated PVC piping and the $1-1 / 2$ inch HDPE line sloping into the ditch. To the remaining end of the $1-1 / 2$ inch HDPE line approximately 23 -foot sections of nylobrade tubing $(1 / 2,3 / 4$, or 1 inch) were alternately hooked up. The nylobrade tubing formed the siphon line crest and terminated within a sump set below the bottom of the ditch. The hypothesis was that due to the reduced line size the flow velocity would increase and sweep the gas out of the line without the requirement for an air chamber.

Table 8 presents the summary results for the siphon line size evaluation. The velocity within the 1 -inch line was less than the minimum velocity required for the transport of large air bubbles out the end of a siphon, as presented in section 3.3. Consistent with the minimum velocity requirement, no bubbles were seen to flush through the 1-inch tubing. Flow essentially stopped after approximately 6 minutes, when one large bubble entered the crest in the 1-inch tubing and stopped in the crest. The velocity within the $3 / 4$-inch line was approximately $50 \%$ greater than the minimum velocity required for the transport of large air bubbles out the end of a siphon, as presented in section 3.3. Consistent with this observation, small bubbles were seen to flush through the $3 / 4$-inch tubing. However flow essentially stopped after approximately 3 minutes, when one large bubble entered the crest in the $3 / 4$-inch tubing and stopped in the crest. The velocity within the $1 / 2$-inch line was significantly greater than the minimum velocity required for 
the transport of large air bubbles out the end of a siphon, as presented in section 3.3. Consistent with this observation, bubbles smaller than 3 -inches-long were seen to flush through the $1 / 2$-inch tubing. However, flow essentially stopped after approximately 4 minutes, when one 12 -inch long bubble entered the crest in the $1 / 2$-inch tubing and stopped in the crest.

Degassing within the siphon line probably does not initially result in the formation of bubbles of the size necessary to stop flow in the $1 / 2$ and $3 / 4$-inch lines. Such large bubbles are probably the result of small bubble accumulation and agglomeration at points of discontinuities within the siphon line or at points of inconsistent grade, which create localized high points in the line. Such discontinuities or localized high points prohibit the movement of smaller bubbles and promote accumulation and agglomeration. Such accumulation and agglomeration was seen during testing of siphon line configurations 3 and 4. As stated in sections 4.3.3 and 4.3.4, gas bubbles formed at the cell head could be seen accumulating and agglomerating at the insert fitting between the clear PVC and the subsequent HDPE pipe, until the bubble was large enough to be forced past the fitting. Then the larger bubble would move with the water flow. Large bubbles formed in such a manner are probably responsible for the stoppage of flow in the $1 / 2$ and $3 / 4$-inch lines. Therefore in order for the use of minimum flushing velocity to potentially be viable as a method of removing gas from the siphon line, in lieu of air chamber usage, line discontinuities and localized high points, which promote bubble accumulation and agglomeration must be eliminated. One continuous pipe without fittings placed on an engineered grade with one crest would probably be the optimal configuration for the use of minimum flushing velocity as the means for removing gas from the siphon line. Alternately one continuous larger diameter pipe without fittings on the upward leg of the siphon line followed by a smaller diameter pipe utilized for the crest and downward leg of the siphon line could be used. This would minimize head loss. However the fitting between the two pipes could not have an abrupt change in inside diameter, which would promote the accumulation and agglomeration of bubbles. Additionally, the interrelated parameters of siphon line diameter, fluid flow velocity, and bubble size appear to be the parameters, which influence the ability to remove gas from a siphon line through the use of a minimum flushing velocity. All three parameters must be considered when designing a siphon line to maintain full flow through the use of minimum flushing velocity. 
Table 8

Siphon Line Size Evaluation Summary Results

\begin{tabular}{|c|c|c|c|c|c||}
\hline $\begin{array}{c}\text { Line } \\
\text { Size } \\
\text { (inch) }\end{array}$ & $\begin{array}{c}\text { Flow } \\
\text { Rate } \\
(\mathrm{gpm})\end{array}$ & $\begin{array}{c}\text { Flow } \\
\text { Velocity } \\
\text { (ft/s) }\end{array}$ & $\begin{array}{c}\text { Min. } \\
\text { Velocity } \\
\text { (ft/s) }\end{array}$ & $\begin{array}{c}\text { Flow } \\
\text { Duration } \\
\text { (min) }\end{array}$ & Comments \\
\hline $1 / 2$ & 1.25 & 2.0 & 0.67 & 4 & $\begin{array}{c}\text { Approximately 3-inch long and smaller } \\
\text { bubbles flushed through line; flow } \\
\text { stopped after one 12-inch long bubble } \\
\text { stopped in the crest }\end{array}$ \\
\hline $3 / 4$ & 1.72 & 1.25 & 0.82 & 3 & $\begin{array}{c}\text { Small bubbles flushed through line; flow } \\
\text { stopped after one large bubble stopped in } \\
\text { the crest }\end{array}$ \\
\hline 1 & 1.90 & 0.78 & 0.95 & 6 & $\begin{array}{c}\text { No bubbles flushed through line; flow } \\
\text { stopped after one large bubble stopped in } \\
\text { the crest }\end{array}$ \\
\hline
\end{tabular}

Actual velocity of flow in tubing

${ }^{2}$ Minimum velocity of flow per $\mathrm{V}=0.58(\mathrm{SQRT}(\mathrm{gD})$ ) to flush bubble of a siphon line (see section 3.3)

\subsubsection{Phase II Siphon Hydraulics Test Results Summary}

Testing of four different siphon line configurations was conducted during Phase II testing from June 18,1998 to September 4,1998. Additionally a one-day minimum flushing velocity test was conducted on November 13, 1998.

The initial siphon line configuration consisted of approximately 1032 feet of $1-1 / 2$ inch pipe laid directly on the ground surface from the cell to the Savannah River, which created localized high points at various points within the line. The second and third siphon line configurations also consisted of 1032 feet of $1-1 / 2$ inch pipe between the cell and the Savannah River. However, these configurations included the use of an air chamber to try and maintain full flow in the line, and the use of engineered grades for the first 305-ft of the siphon line from the cell. The last 727 feet of line for the second and third configurations was laid directly on the ground surface within the $\mathrm{X}-08$ outfall ditch, which resulted in localized high point at various points within this portion of the line. The fourth configuration consisted of 305 feet of $1-1 / 2$ inch pipe on a consistent engineered slope, with both the up-gradient (at 1:100 slope) and down-gradient legs (at $22-12^{\circ}$ slope) from the air chamber sloping upward toward the air chamber. All siphon line configurations had discontinuities within the siphon line inside diameter produced by various fittings used. Table 6 provides more detailed information for each siphon line configuration. 
Operation of the initial configuration (without an air chamber) resulted in initial flow rates near the calculated level, followed by diminishing flow over a matter of hours to essentially zero. Repriming was required to initiate operation again. It was determined that degassing from the treated water, lack of complete gas transport out of the line, and the subsequent accumulation of the gas within the siphon line was the cause of siphon breakage. Based upon the results from the initial siphon line configuration, it was decided that an air chamber would be installed to try and maintain full flow in the siphon line by removing gases that degassed from the siphon line.

Operation of the second and third siphon line configurations resulted in initial flow rates at less than the calculated levels, followed by diminishing flow over a matter of hours to essentially zero. Re-priming was required to initiate operation again. It was determined that entrapment of the gas within those portions of the siphon line not influenced by the air chamber was the cause of both initial reduced flow rates and eventual siphon breakage. In particular degassing and gas entrapment within localized high points in that portion of the line within the X-08 outfall ditch was identified as the problem. Even during re-priming events some gas remained entrapped within this portion of the line. However the rate of flow rate decline (see Table 7) improved with each successive configuration. This improvement indicated that the use of the air chamber was improving siphon operation, and that the length of line influenced by the air chamber increased between the second and third configurations.

The fourth siphon line configuration was the same as that of the third, except that the 727 feet of line within the X-08 outfall ditch, which had localized high points, was removed. Operation of the fourth siphon line configuration resulted in continuous, consistent operation with flow rates consistent with calculated values (see Figure 25). Re-priming was not required. However, air chamber water recharging was required on a periodic basis. This siphon line configuration with air chamber was able to maintain full siphon line flow by removal of gas bubbles from in its entire 305-foot length.

The minimum flushing velocity test concluded that in order for minimum flushing velocity to be potentially viable as a method of removing gas from the siphon line, in lieu of air chamber usage, line discontinuities and localized high points, which promote bubble accumulation, agglomeration, and potentially entrapment must be eliminated. One continuous pipe without fittings placed on an engineered grade with one crest would probably be the optimal

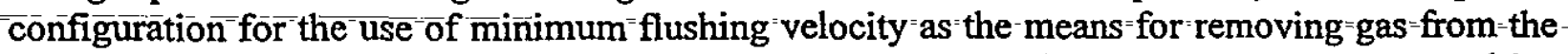
siphon line. Alternately one continuous larger diameter pipe without fittings on the upward leg of the siphon line followed by a smaller diameter pipe utilized for the crest and downward leg of the siphon line could be used. This would minimize head loss. However the fitting between the two pipes could not have an abrupt change in inside diameter, which would promote the accumulation and agglomeration of bubbles. Additionally, the inter-related parameters of siphon line diameter, fluid flow velocity, and bubble size appear to be the parameters, which influence the ability to remove gas from a siphon line through the use of a minimum flushing velocity. 
All three parameters must be considered when designing a siphon line to maintain full flow through the use of minimum flushing velocity.

Within all the testing, the management of gas within the siphon line was determined to be of utmost important in maintenance of siphon flow. Siphon line gas management requires control of gas bubble transport, accumulation, and agglomeration and elimination of gas bubble entrapment. Gas bubble transport, accumulation, agglomeration, and entrapment are controlled by fluid flow velocity, gas buoyancy, and siphon line grades and inside diameter discontinuities (i.e. fittings). Gas bubble transport in the upward leg of the siphon line is facilitated by higher fluid flow velocities, a continuous upward siphon line grade (no localized high points), and the minimization or elimination of fittings, which produce discontinuities in the inside diameter of the siphon line. The continuous upward grade and elimination of such fittings promotes buoyancy transport in the same direction as fluid flow and eliminates the accumulation, agglomeration, and entrapment of gas bubbles in the upward leg of the siphon line. The fluid flow velocity in the upward leg is not as critical as it is in the downward leg of the siphon line, and the upward leg fluid flow velocity should be balanced against minimization of head loss to maximize overall flow rates.

The direction of gas bubble transport, if any, in the siphon line downward leg is determined by whether transport due to fluid flow velocity or gas buoyancy is dominant. Fluid flow velocity tends to cause the gas bubbles to move downward in the downward leg of the siphon line toward the end of the line. Gas buoyancy tends to cause the gas bubbles to move upward in the downward leg of the siphon line toward the siphon crest.

In order to utilize minimum flushing velocity to maintain full flow in the siphon line downward leg, the fluid flow velocity must be dominant in the downward leg. That is the fluid flow velocity must be greater than the required minimum (see section 3.3). Additionally a continuous, downward, siphon line, grade (i.e., no localized high points) and the minimization or elimination of fittings, which produce discontinuities in the inside diameter of the siphon line, is necessary. The continuous downward grade and elimination of such fittings eliminates the accumulation, agglomeration, and entrapment of gas bubbles in the downward leg of the siphon line.

In order to utilize an air chamber to maintain full flow in the siphon line downward leg, the gas buoyancy must be dominant in the downward leg. That is the fluid flow velocity must be less than the minimum outlined in section 3.3, and the downward slope of the siphon line must be continuous (i.e. no localized high points) and steep enough for gas buoyancy to overcome the fluid flow velocity. This allows gas transport up the downward leg to the crest, where the air chamber is located. Additionally fittings, which could entrap gas bubbles, should be minimized. The continuous downward grade and minimization of such fittings eliminates the accumulation, agglomeration, and entrapment of gas bubbles in the downward leg of the siphon line.

Under the Phase II testing conditions the following were observed relative to gas bubble

$$
\text { Page } 29 \text { of } 92
$$


transport within the siphon line downward leg:

- The buoyancy of gas bubbles in the $1-1 / 2$ inch siphon line downward leg (sloped at 1:100 downward from the air chamber) could not overcome the water flow velocity in the opposite direction in order to travel upstream back to the air chamber.

- The buoyancy of gas bubbles in the 1-1/2 inch siphon line downward leg sloped at 22 $1 / 2^{\circ}$ downward from the air chamber could overcome the water flow velocity in the opposite direction in order to travel to the air chamber.

\subsection{PHASE II SIPHON LINE PRIMING}

The following different siphon line priming methods were utilized during the Phase II testing:

- Use of an impeller pump to suction fill both the siphon line downward and upward leg from the crest

- Use of an impeller pump to suction fill both the siphon line downward and upward leg from the line's exit

- Use of an impeller pump to pressure fill the siphon line downward leg through the crest with the line's exit valved off (air had to be released from the downward leg through the crest) and then suction fill the upward leg from the crest

- Use of an impeller pump to pressure fill the siphon line downward leg through the line's exit and then suction fill the upward leg from the crest

- Use of a gas driven vacuum pump to suction fill both the siphon line downward and upward legs from the crest

The impeller pump utilized was an ITT-Jabsco flexible impeller pump Model \#4720-001 with a maximum 15-foot suction lift. A portable generator was utilized to power the impeller pump. The nitrogen driven vacuum pump was a Vaccon Vacuum Pump Model JS-60M with a maximum 28 inch-Hg ( 31.7-foot) suction lift. A 300 cubic foot nitrogen gas cylinder rated at $2640 \mathrm{psig}$ (the cylinder was nominally 1800 to $2000 \mathrm{psig}$ as delivered to the field) was utilized to drive the gas driven vacuum pump.

Due to the lift required, the impeller pump was not able to adequately fill the siphon line downward leg by suction from the crest. Although the impeller pump was able to essentially fill the entire siphon line by suction from the line's exit, air remained in the crest and could not be removed by this method. The impeller pump was able to pressure fill the downward leg through the crest and suction fill the upward leg from the crest, however this required various valving and pump hookup configurations, which added time to the process. The impeller pump was able to pressure fill the downward leg through the line's exit and suction fill the upward leg from the crest, however this required various valving configurations and a pump relocation from the exit to the crest, which added significant time and effort to the process. The gas driven vacuum

$$
\text { Page } 30 \text { of } 92
$$


pump was able to fairly quickly and easily suction fill both the siphon line downward and upward legs from the crest. Use of the gas driven vacuum pump proved to be the most efficient method of priming the siphon line.

Siphon line priming is also impacted by the presence of any localized high points within the siphon line. None of the methods of priming utilized will eliminate all air from the siphon line if localized high points exist. Air becomes entrapped in such localized high points and can not be removed with the priming methods utilized. Pressure filling from the line's exit at high flow rates is most likely to be able to remove entrapped air from such localized high points; however this is one of the more labor intensive methods of priming. 
Left Blank Intentionally 


\subsection{SAVANNAH RIVER STAGE}

As outlined in section 4.2, Savannah River water elevations were obtained from two river gauging stations (see Table 5). SRTC/EST personnel operated the SR-TNX gauging station. The SR-Jackson gauging station (station \#02197320) is operated by United States Geologic Survey (USGS) personnel and has been in essentially continuous operation since the 1970s. Slightly greater than 10 years worth (10/1/87 through 5/20/98) of Savannah River Jackson gauging station stage data was obtained from the USGS. A linear regression between the SRTNX gauging station daily mean elevation data and the same day SR-Jackson gauging station daily mean elevation data was performed, utilizing data from $7 / 17 / 97$ to $12 / 31 / 97$ and $4 / 10 / 98$ to 5/11/98 (see Figure 28 and Appendix B). Table 9 provides pertinent statistics for the SR-TNX gauging station actual daily mean elevation data utilized in the linear regression. The following relationship between the river elevations obtained from the two locations was determined (see Appendix B):

$$
\text { SR-TNX Elevation }=0.96550 \times(\text { SR-Jackson Elevation })+2.68956
$$

The $r$ square for this relationship was calculated to be 0.996 , which means that the data sets correlate well and the relationship should represent the data well.

Based upon this relationship between SR-Jackson and SR-TNX actual data, the entire greater than ten year SR-Jackson daily mean elevation data set $(10 / 1 / 87$ to $5 / 20 / 98)$ was converted to estimated SR-TNX daily mean elevation data (see Appendix C). Table 9 provides pertinent statistics for both the actual and estimated SR-TNX daily mean elevation data sets. A comparison of the statistics shows that the actual data utilized to determine the relationship between the SR-Jackson and SR-TNX data represents well the full range of estimated historic elevations. This near full range representation by the actual data provides additional confidence in the above relationship.

Figure 29 provides the estimated Savannah River historic elevations at TNX produced from this conversion. As discussed in section 7.0, a new siphon line for TGSC-1 is proposed for installation and testing based upon the results discussed within this report. It is currently planned to install the end of the new siphon line within the X-08 outfall ditch in a location with an estimated normal water elevation of approximately $88.82 \mathrm{ft}-\mathrm{msl}$ (i.e., when water in the ditch at this location is not backed up due to the Savannah River stage). This proposed elevation has been compared to the estimated Savannah River historic elevations at TNX to determine the expected frequency that the head in this location will be impacted by the Savannah River stage (see Appendix C). It is anticipated that the head in this location of the X-08 outfall ditch will be impacted by the Savannah River stage approximately 27 percent of the time. Such impact may reduce the flow rate through the siphon line due to a potential reduction in available driving

$$
\text { Page } 33 \text { of } 92
$$


head. However this may be offset somewhat by associated rises in groundwater levels at the cell.

Table 9

$\underline{\text { SR-TNX Gauging Station Daily Mean Elevation Data Statistics }}$

\begin{tabular}{||c|c|c|c|c|}
\hline & Mean & Median & Minimum & Maximum \\
\hline Actual Data $^{1}$ & 86.81 & 85.06 & 81.97 & 94.94 \\
\hline Estimated Data $^{2}$ & 86.70 & 85.43 & 80.94 & 96.11 \\
\hline
\end{tabular}

Actual field data collected from 7/17/97 to $12 / 31 / 97$ and 4/10/98 to 5/11/98 (see Figure 28 and Appendix B)

2 Estimated data from $10 / 1 / 87$ to $5 / 20 / 98$ determined from the above relationship between the SR-Jackson and SR-TNX data (see Appendix C) 


\subsection{PHASE II SAMPLING AND ANALYSIS}

Minimal sampling and analysis was conducted during Phase II testing. The primary treatability aspects of the TNX GeoSiphon Cell (TGSC-1) were addressed during Phase I testing and documented in the Phase I Final Report (see WSRC-TR-98-00032). The following sampling and analysis was performed during Phase II testing:

- Pre-operational water sampling and analysis for selected chlorinated volatile organic compounds (CVOCs), field parameters, metals, anions, and microbial density and diversity

- Operational water sampling and analysis for selected CVOCs and field parameters

- Operational NPDES water sampling and analysis for selected CVOCs and acute toxicity

- Operational air sampling and analysis of the siphon line air chamber off-gases for permanent gases, hydrogen, light hydrocarbons, and selected CVOCs

[WSRC-TR-98-00032; Q-TPL-T-00004]

\subsection{SAMPLING}

Selected sampling during testing was conducted from the sample locations presented in Table 10 and shown in Figures 3, 4, and 5. Pre-operational water samples were taken from sample locations TCM-2 (influent), TGSC-1A through TGSC-1H, and TGSC-1 (effluent) for analysis of selected chlorinated volatile organic compounds (CVOCs), field parameters, metals, anions, and selected microbial parameters. Operational water samples were taken from sample locations TCM-2 (influent) and TGSC-1 (effluent) for analysis of selected CVOCs and field parameters. Operational water samples were also taken for NPDES compliance from sample location TGSC1 (effluent) for analysis of selected CVOCs and acute toxicity. Operational gas samples were taken from the air chamber for permanent gases, hydrogen, light hydrocarbons, and selected CVOCs. 
Table 10

Sample Locations

\begin{tabular}{||c|c|c|c||}
\hline $\begin{array}{c}\text { Sample } \\
\text { Location }\end{array}$ & $\begin{array}{c}\text { Distance into } \\
\text { Iron Bed } \\
\text { (ft) }\end{array}$ & Location & Comments \\
\hline TCM-2 & 0 & Influent & $\sim 25 \mathrm{ft}$ upgradient \\
\hline TGSC-1A & 0 & Influent & Immediately upgradient $^{2}$ \\
\hline TGSC-1B & 0.14 & Within iron & 2 \\
\hline TGSC-1C & 0.32 & Within iron & 2 \\
\hline TGSC-1D & 0.64 & Within iron & 2 \\
\hline TGSC-1E & 1.07 & Within iron & 2 \\
\hline TGSC-1F & 1.50 & Within iron & 2 \\
\hline TGSC-1G & 2.04 & Within iron & 2 \\
\hline TGSC-1H & 2.86 & Within iron & 2 \\
\hline TGSC-1 & 3.47 & Effluent & Immediately downgradient \\
\hline Air & $\begin{array}{c}\text { Not } \\
\text { Applicable }\end{array}$ & Effluent & $\begin{array}{c}\text { Located in crest of siphon } \\
\text { line }\end{array}$ \\
\hline
\end{tabular}

TCM-2 is a 4-inch diameter well screened over the entire GeoSiphon treatment zone depth (see Figure 3 and Table 4). Samples from TCM-2 represent the average influent to the GeoSiphon Cell.

${ }^{2}$ Sample ports, TGSC-1A through TGSC-1H, are stainless steel tubes with 3-inch screen zones all at an approximate elevation of $87 \mathrm{ft}$-msl (see Figures 4 and 5). Samples from them represent the concentrations along one horizontal, radial, flow path.

${ }^{3}$ Sample location TGSC-1 includes all samples taken from within the 12-inch central screen zone (see Figures 4 and 5). The NPDES TGSC-1 samples were taken with either a bailer or an ISCO sampler from within the 12-inch central screen zone at an elevation of approximately $82 \mathrm{ft}$-msl. All other samples were taken from a stainless steel tube with a 3 -inch screen attached to the $1-1 / 2$ inch siphon line located inside the 12-inch central screen at the same elevation as TGSC-1A through TGSC-1H. All samples taken from within the 12-inch screen represent the average discharge from the GeoSiphon Cell.

Samples from monitoring well TCM-2 (see Figure 3 for location) were taken by Environmental Sciences and Technology Department (EST) personnel utilizing a dedicated Grundfos Redi-Flo II submersible pump. One well volume of water was evacuated (the evacuated water was contained in an IDW drum for proper disposition) prior to obtaining a sample. The sample was collected in an appropriate sample bottle (see Table 12) from the discharge tubing, after the flow rate had been reduced so that splashing and contact with air was minimized. The bottle was immediately capped 
after the sample had been collected.

The SS sampling tubes (TGSC-1A through TGSC-1; see Figures 4 and 5) consist of $1 / 4$ inch OD SS tubing (0.049 inch wall thickness) perforated as shown in Figure 5. A 1/8 inch OD, 1/16 inch ID nylon tube has been inserted into the SS tubing to within $\sim 3$ inch of the bottom of the SS tubing, and the nylon tubing extends above the top of the SS tubing. A small section of Tygon tubing (1/4 inch OD, 1/8 inch ID) with a tubing clamp connects the nylon tubing with a dedicated $60 \mathrm{ml}$ plastic syringe, which was used to collect the samples. EST personnel sampled these sample locations as follows:

- A new $60 \mathrm{ml}$ plastic syringe was utilized for each sampling location and event.

- The syringe plunger was pushed all the way down.

- The syringe was connected to the Tygon tubing.

- The tubing clamp on the Tygon tubing was released.

- The syringe plunger was slowly and gently pulled back so that approximately $20 \mathrm{ml}$ of liquid was taken into the syringe (this purge was conducted to clear the nylon/SS tubing of stagnant water prior to actual sampling).

- The tubing clamp on the Tygon tubing was closed.

- The $60 \mathrm{ml}$ syringe was disconnected from the Tygon tubing while the liquid in the Tygon tubing was maintained (wanted to minimize air in the system to prevent volatilization of the organics).

- The syringe was pointed upward, and the air and liquid in the syringe was discharged by slowly and gently pushing the plunger, all the way down. All air was eliminated from the syringe, and the liquid was maintained in the tip of the syringe (the purge liquid was maintained in an Investigative Derived Waste (IDW) drum for proper disposition).

- The syringe was reconnected to the Tygon tubing in a manner that minimized air in the tubing and syringe.

- The tubing clamp was released from the Tygon tubing.

- The syringe plunger was slowly and gently pulled back so that the required sample volume up to $60 \mathrm{ml}$ in the syringe was obtained.

- The tubing clamp on the Tygon tubing was closed.

- The syringe was disconnected from the Tygon tubing while maintaining the liquid in the Tygon tubing (wanted to minimize air in the system to prevent volatilization of the organics).

- The sample was slowly and gently discharged into the appropriate sample bottle (see Table

12) in a manner that minimized contact with air (minimized splashing) and the sample bottle was immediately capped.

- The syringe was appropriately disposed after each sampling event.

The NPDES TGSC-1 samples were taken by Environmental Monitoring Section (EMS) personnel per standard NPDES sampling procedures from within the 12-inch central screen zone at an elevation of approximately $82 \mathrm{ft}-\mathrm{msl}$. The samples for the selected CVOCs were taken as a grab

$$
\text { Page } 37 \text { of } 92
$$


sample with a bailer and placed in $40 \mathrm{ml}$ volatile organic analysis (VOA) bottles (see Table 12). The samples for acute toxicity were taken as 24 -hour flow proportional samples with an ISCO sampler.

EMS subcontractor personnel (Microseeps) took air samples from the siphon line air chamber. The air chamber $3 / 8$-inch polyethylene sight glass was teed to a 3/8-inch valve, which was connected to a 3/8-inch polyethylene sample tube with septa (see Figure 12). A $500 \mathrm{ml}$ gas-tight syringe and needle with a three-way valve was inserted into the sample tube septa, and the sample tube was purged of atmospheric air prior to sampling. The valve between the air chamber sight glass and the sample tube was then opened, and the samples were taken with the syringe. The samples were placed in $250 \mathrm{ml}$ amber, septa top bottles that had been previously evacuated of air (see Table 12).

[Q-TPL-T-00004]

\subsection{SAMPLE ANALYSIS}

Pre-operational water phase analyses included selected chlorinated volatile organic compounds (CVOCs), field parameters, metals, anions, and microbial parameters from sample locations TCM-2, TGSC-1A through TGSC-1H, and TGSC-1. Operational water phase analyses included selected CVOCs and field parameters samples from sample locations TCM-2 and TGSC-1. Operational water phase analyses also included selected CVOCs and acute toxicity for NPDES compliance from sample location TGSC-1. Operational gas phase analyses included permanent gases, hydrogen, light hydrocarbons, and selected CVOCs samples from the air chamber. Table 11 presents the pre-operational and operational laboratories, sample medium, and analytes. Table 12 presents the analytical methods utilized by each laboratory and the sample bottles utilized for sample collection. 
Table 11

Pre-operational and Operational Laboratory, Sample Medium, and Analytes

\begin{tabular}{|c|c|c|}
\hline Laboratory & $\begin{array}{l}\text { Sample } \\
\text { Medium }\end{array}$ & Analytes \\
\hline \multicolumn{3}{|r|}{ Pre-operational Analytes } \\
\hline EST & Water & $\begin{array}{l}\text { Trichloroethylene, cis-1,2-dichloroethylene, carbon tetrachloride, } \\
\text { and chloroform }\end{array}$ \\
\hline EST & Water & $\mathrm{pH}$, Eh, DO, and temperature \\
\hline ADS & Water & $\begin{array}{l}\text { Silver, aluminum, boron, barium calcium, cadmium, cobalt, } \\
\text { chromium, copper, iron, lanthanum, lithium, magnesium, } \\
\text { manganese, molybdenum, sodium, nickel, phosphorus, lead, silica, } \\
\text { tin, strontium, titanium, vanadium, zinc, and zirconium }\end{array}$ \\
\hline$\overline{\mathrm{ADS}}$ & Water & $\begin{array}{l}\text { Chloride, fluoride, formate, nitrate, nitrite, oxalate, phosphate, and } \\
\text { sulfate }\end{array}$ \\
\hline EST & Water & $\begin{array}{c}\text { Microbial direct counts, aerobic plate counts, and diversity } \\
\text { measurements }\end{array}$ \\
\hline \multicolumn{3}{|r|}{ Operational Analytes } \\
\hline EST & Water & $\begin{array}{l}\text { Trichloroethylene, cis-1,2-dichloroethylene, carbon tetrachloride, } \\
\text { and chloroform }\end{array}$ \\
\hline EST & Water & $\mathrm{pH}, \mathrm{Eh}$, and temperature \\
\hline $\begin{array}{l}\text { Shealy } \\
\text { Environmen } \\
\text { tal Services, } \\
\text { Inc. }\end{array}$ & Water & $\begin{array}{l}\text { Tetrachloroethylene, trichloroethylene, cis-1,2-dichloroethylene, } \\
\text { vinyl chloride }\end{array}$ \\
\hline $\begin{array}{c}\text { Shealy } \\
\text { Environmen } \\
\text { tal Services, } \\
\text { Inc. }\end{array}$ & Water & $\begin{array}{c}\text { Ceriodaphnia Dubia, } 48 \text {-hour, Static, Acute Toxicity Test at an in } \\
\text { stream waste concentration (IWC) of } 33 \%\end{array}$ \\
\hline Microseeps & Gas & $\begin{array}{l}\text { Carbon dioxide, oxygen, nitrogen, carbon monoxide, methane, } \\
\text { ethane, ethylene, propane, propylene, 1-Butane, n-Butane, } \\
\text { hydrogen, tetrachloroethylene, trichloroethylene, cis-1,2- } \\
\text { dichloroethylene, trans-1,2-dichloroethylene, vinyl chloride, carbon } \\
\text { tetrachloride, chloroform, methylene chloride, and 1,1,1- } \\
\text { trichloroethane }\end{array}$ \\
\hline
\end{tabular}

Notes:

EST - Savannah River Technology Center (SRTC) Environmental Sciences and Technology Department (EST)

ADS - Savannah River Technology Center (SRTC) Analytical Development Section (ADS) IWC $=$ in stream waste concentration 
Table 12

Analytical Methods and Sample Bottles

\begin{tabular}{|c|c|c|c|c|}
\hline Laboratory & Analytes & $\begin{array}{l}\text { Analytical } \\
\text { Method }\end{array}$ & $\begin{array}{l}\text { Sample } \\
\text { Volume }\end{array}$ & $\begin{array}{l}\text { Sample } \\
\text { Bottle }\end{array}$ \\
\hline$\overline{\text { EST }}$ & $\begin{array}{l}\text { Trichloroethylene, cis-1,2-dichloroethylene, } \\
\text { carbon tetrachloride, and chloroform }\end{array}$ & $\begin{array}{c}\mathrm{GC}- \\
\mathrm{ECD} / \mathrm{FID}\end{array}$ & $7.5 \mathrm{ml}$. & $\begin{array}{c}20 \mathrm{ml} \\
\text { headspace } \\
\text { vials }\end{array}$ \\
\hline EST & $\begin{array}{c}\mathrm{pH} \\
\mathrm{Eh} \\
\mathrm{DO} \\
\text { temperature }\end{array}$ & $\begin{array}{c}\text { Orion } \\
\text { Oakton } \\
\text { YSI } \\
\text { Orion }\end{array}$ & $20 \mathrm{ml}$ & $\begin{array}{l}\text { HDPE } \\
\text { bottle }\end{array}$ \\
\hline$\overline{\mathrm{ADS}}$ & $\begin{array}{l}\text { Silver, aluminum, boron, barium calcium, } \\
\text { cadmium, cobalt, chromium, copper, iron, } \\
\text { lanthanum, lithium, magnesium, manganese, } \\
\text { molybdenum, sodium, nickel, phosphorus, } \\
\text { lead, silica, tin, strontium, titanium, } \\
\text { vanadium, zinc, and zirconium }\end{array}$ & ICP-ES & $20 \mathrm{ml}$ & $\begin{array}{l}20 \mathrm{ml} \\
\mathrm{HDPE} \\
\text { bottle }\end{array}$ \\
\hline$\overline{\mathrm{ADS}}$ & $\begin{array}{l}\text { Chloride, fluoride, formate, nitrate, nitrite, } \\
\text { oxalate, phosphate, and sulfate }\end{array}$ & IC Anion & $20 \mathrm{ml}$ & $\begin{array}{l}20 \mathrm{ml} \\
\text { HDPE } \\
\text { bottle }^{1}\end{array}$ \\
\hline EST & $\begin{array}{l}\text { Microbial direct counts, aerobic plate } \\
\text { counts, and diversity measurements }\end{array}$ & 3 & $50 \mathrm{ml}$ & $\begin{array}{c}50 \mathrm{ml} \\
\text { HPDE } \\
\text { centrifuge } \\
\text { tubes }\end{array}$ \\
\hline $\begin{array}{c}\text { Shealy } \\
\text { Environmental } \\
\text { Services, Inc. }\end{array}$ & $\begin{array}{l}\text { Tetrachloroethylene, trichloroethylene, cis- } \\
\text { 1,2-dichloroethylene, vinyl chloride }\end{array}$ & $\begin{array}{c}\text { SW } 846 \\
\text { Method } \\
8260\end{array}$ & $80 \mathrm{ml}$ & $\begin{array}{c}40 \mathrm{ml} \text { VOA } \\
\text { bottles }\end{array}$ \\
\hline $\begin{array}{c}\text { Shealy } \\
\text { Environmental } \\
\text { Services, Inc. }\end{array}$ & $\begin{array}{c}\text { Ceriodaphnia Dubia, 48-hour, Static, Acute } \\
\text { Toxicity Test at an IWC of } 33 \%\end{array}$ & $\begin{array}{c}\text { EPA-600/4- } \\
90-027 \\
\text { (Weber) }\end{array}$ & $4 \mathrm{~L}$ & $\begin{array}{l}\text { 2 L HDPE } \\
\text { Bottles }\end{array}$ \\
\hline Microseeps & $\begin{array}{c}\text { - Carbon dioxide, oxygen, nitrogen, carbon } \\
\text { monoxide; } \\
\text { - Methane, ethane, ethylene, propane, } \\
\text { propylene, 1-Butane, n-Butane; }\end{array}$ & & $250 \mathrm{ml}$ & $\begin{array}{c}\text { Air } \\
\text { evacuated } \\
250 \mathrm{ml} \\
\text { amber, } \\
\text { septa top }\end{array}$ \\
\hline & $\begin{array}{l}\text { Tetrachloroethylene, trichloroethylene, } \\
\text { cis-1,2-dichloroethylene, trans-1,2- } \\
\text { dichloroethylene, vinyl chloride, carbon } \\
\text { tetrachloride, chloroform, methylene } \\
\text { chloride, and 1,1,1-trichloroethane }\end{array}$ & & & bottle \\
\hline
\end{tabular}


Notes to Table 12:

'After sample collection, the samples were refrigerated until analyzed.

${ }^{2}$ The sample was preserved with $1 \mathrm{ml}$ of $36.5-38 \%$ Regent, ACS, $\mathrm{HCl}$.

${ }^{3}$ See write up below concerning the microbial parameter analytical methods. After sample collection, the samples were refrigerated at $4^{\circ} \mathrm{C}$ until analyzed.

${ }^{4}$ Groundwater was added to the VOA sample bottles until they were completely full and could be capped without air in the bottle. After sample collection, the samples were refrigerated until analyzed.

EST - Savannah River Technology Center (SRTC) Environmental Sciences and Technology Department (EST)

ADS - Savannah River Technology Center (SRTC) Analytical Development Section (ADS)

GC-ECD/FID - gas chromatograph with an electron capture detector and a flame ionization detector Orion - Orion Modal 250A portable $\mathrm{pH}$ meter and probe or equal

Oakton - Oakton WD-35615-60 Series portable $\mathrm{pH} / \mathrm{mV} /$ temperature meter with a double junction ORP electrode or equal

YSI - YSI Model 58 DO meter with Series 5700 oxygen probe or equal

ICP-ES - Inductively Coupled Plasma-Emission

IC Anion - Ion chromatography for Anions

The following three microbiological tests were performed:

- Direct counts were used to determine overall densities of microorganisms.

- Aerobic plate counts were done to determine the number of viable aerobic organisms present in each sample.

- Diversity measurements were done to determine the number of different carbon sources that could be oxidized by the microorganisms present in each sample.

To determine the total microbial density by direct counts, samples were vortexed in the $50 \mathrm{ml}$ pre-sterilized polyethylene centrifuge tubes used to pull the sample for 30 seconds and then $50 \mu \mathrm{l}$ of sample was spotted onto six wells of an eight well toxoplasmosis slide. Each slide was alcohol rinsed before use and then placed on a $65^{\circ} \mathrm{C}$ hot plate during spotting. All samples were then heat fixed, on the hot plate, for 12-15 minutes. After heat fixing the sample, the slide was removed from the hot plate and stained with fluorescein isothiocyanate (FITC) for 2 minutes. Each slide was rinsed with filtered deionized water and allowed to air dry. The slides were examined using a Zeiss epi-fluorescent microscope (ID \#00096054). The field of view for the microscope was calibrated using a micrometer (M\&TE \#ES-101). The microbial densities were calculated based on the number of cells counted, area of the field, area of the toxoplasmosis well, and the volume of water spotted on the slide. [SRT-EST-98-145] 
Aerobic plate counts were performed using a spread plate method. Four serial dilutions were made from each of the original samples by pipetting $1 \mathrm{ml}$ of sample into $9 \mathrm{ml}$ of filter sterilized FA buffer (Difco Laboratories), vortexing for 30 seconds, then repeating the transfer using the diluted sample to provide the $1 \mathrm{ml}$ for the next dilution. One hundred micro-liters of sample was spotted onto an uncovered plastic petri plate with $1 \%$ peptone-tryptone-yeast-glucose (PTYG) agar. Each sample was then spread over the agar plate using an alcohol rinsed flame sterilized glass rod by manually rotating an inoculating turntable. Duplicate spread plates were made from each of the four dilutions, from the original sample container, and from the filtered FA buffer for negative controls. All of this work was done in a bioflow fume hood. Once covered, the plates were inadvertently placed in a $37^{\circ} \mathrm{C}$ incubator for one day, once found the plates were moved and allowed to incubate at $25^{\circ} \mathrm{C}$ for 6 additional days. Inactivation (not mortality) of some of the aerobic microorganisms may have occurred at $37^{\circ} \mathrm{C}$. However, some of the microorganisms may have actually grown at a much faster rate. The microbes that were potentially inactivated during the period at $37^{\circ} \mathrm{C}$ probably remained viable and their enzyme activity and growth continued during the $25^{\circ} \mathrm{C}$ incubation period. Therefore the results obtained from this test are considered representative. Even if this inadvertent one day elevated temperature incubation did negatively impact the absolute counts, all the samples were subjected to the same conditions and should provide accurate relative counts. After incubation, microcolonies were visually counted to determine the density of microorganisms based on the dilution value and the average number of microcolonies counted. [SRT-EST-98-145]

Gram negative (GN) Biolog ${ }^{\mathrm{TM}}$ plates were used to determine the diversity of ecofunctional enzymes present in each sample. Each plate consists of 96 total cells containing a tetrazolium indicator dye with 95 of the cells containing different organic substrates. To prepare each test plate, $150 \mu \mathrm{l}$ of vortexed sample water was aseptically pipetted in all the cells and allowed to incubate at $25^{\circ} \mathrm{C}$ for 5 days. Positive results, indicated by a color change in the tetrazolium dye, were then determined visually for each of the 95 cells on the plate containing an organic substrate. The ninety-sixth cell was used as a negative control, since it does not have a substrate present in the cell. The results were then grouped together based on the chemical structure of the different organic substrates. [SRT-EST-98-145]

[Q-TPL-T-00004]

\section{3-SAMPLE-ANALYSIS-RESULTS}

As stated previously minimal sampling and analysis was conducted during Phase II testing. The primary treatability aspects of the TNX GeoSiphon Cell (TGSC-1) were addressed during Phase I testing and documented in the Phase I Final Report (see WSRC-TR-98-00032). 


\subsubsection{Field/CVOC/Inorganic/Toxicity Water Phase Results}

As detailed in the Phase I Final Report (see WSRC-TR-98-00032), the chemical composition of water that passes through the GeoSiphon Cell.is changed due to the occurrence of several reactions. The corrosion of iron by water (i.e., the oxidation of the zero valent iron and the reduction of water) dominate these reactions. Other modifying reactions include the corrosion of iron by dissolved oxygen, the reduction of the CVOCs, nitrate, and sulfate, and the precipitation of pyrite $\left(\mathrm{FeS}_{2}\right)$, ferrous iron carbonate $\left(\mathrm{FeCO}_{3}\right)$, and ferrous iron hydroxide $\left(\mathrm{Fe}(\mathrm{OH})_{2}\right)$. These reactions result in significant changes in the chemical composition of the treated water. Iron corrosion results in an Eh decrease (oxidation/reduction potential), a $\mathrm{pH}$ increase, oxygen depletion, the production of dissolved ferrous iron $\left(\mathrm{Fe}^{+2}\right)$ and hydrogen gas, and the subsequent precipitation of ferrous carbonate and ferrous hydroxide. Trichloroethylene (TCE), cis-1,2dichloroethylene (cDCE), carbon tetrachloride (CT), and chloroform (TCM) reduction results in ethene, ethane, methane, and chloride ions as final end products. Nitrate reduction results in the production of ammonium ions. Sulfate reduction results in the production of sulfide, and the subsequent precipitation of pyrite. [WSRC-TR-98-00032]

The summary field, CVOC, inorganic, and toxicity data produced during Phase II testing is presented in Tables 13 and 14. Table 13 presents the summary field, CVOC, and inorganic data produced by SRTC EST and ADS (the detailed CVOC, field, and inorganic data is presented in Appendices D, E, and F, respectively). Table 14 presents the CVOC and toxicity data produced by Shealy Environmental Services, Inc. for NPDES compliance purposes. The Phase II data is consistent with the Phase I data documented in WSRC-TR-98-00032, and summarized above. The following are the only significant differences between the Phase I and Phase II data:

- During Phase I testing, manganese concentrations significantly increased over influent concentrations at all flow rates followed by lower but still elevated concentrations at the cell's effluent. The one Phase II manganese data point collected during no flow conditions indicates a decrease in manganese effluent concentrations over influent concentrations.

- The one Phase II TCE influent sample (TCM-2) collected under condition of flow (2.56 gpm) had a concentration of approximately $110 \mathrm{ppb}$ that was approximately half the typical influent recorded during Phase I.

[WSRC-TR-98-00032]

Other items of note from the Phase II data include:

- All effluent PCE, TCE, CT, CTM, and vinyl chloride (VC) concentrations were less than the detection limits.

- All effluent cDCE concentrations were less than $3 \mu \mathrm{g} /$. 
- All Ceriodaphnia Dubia, 48-hour, Static, Acute Toxicity Tests at an in stream waste concentration (IWC) of 33\% (i.e., 33\% GeoSiphon effluent and 67\% dilution water) had passing results (i.e., the GeoSiphon effluent is not considered toxic).

Table 13

Summary Field, CVOC, and Inorganic Data

\begin{tabular}{|c|c|c|c|c|c|}
\hline & Sample Date & $6 / 9 / 98$ & $6 / 9 / 98$ & $9 / 2 / 98$ & $9 / 2 / 98$ \\
\hline & Sample & $12: 20$ to & $12: 20$ to & $8: 08$ to & $8: 08$ to \\
\hline & Time & $16: 00$ & $16: 00$ & $10: 35$ & $10: 35$ \\
\hline & \begin{tabular}{|l|} 
Flow (gpm) \\
\end{tabular} & 0.00 & 0.00 & 2.56 & 2.56 \\
\hline \multirow{2}{*}{ Parameter } & \multirow{2}{*}{ Units } & \multicolumn{4}{|c|}{ Sample Location } \\
\hline & & $\begin{array}{c}\text { TCM-2 } \\
\text { (influent) }\end{array}$ & $\begin{array}{l}\text { TGSC-1 } \\
\text { (effluent) }\end{array}$ & $\begin{array}{c}\text { TCM-2 } \\
\text { (influent) }\end{array}$ & $\begin{array}{l}\text { TGSC-1 } \\
\text { (effluent) }\end{array}$ \\
\hline $\mathrm{pH}$ & $\mathrm{pH}$ & 5.17 & 9.6 & 5.65 & 9.6 \\
\hline DO & $\mathrm{mg} / \mathrm{l}$ & 3.2 & 2.1 & NA & $\overline{\mathrm{NA}}$ \\
\hline $\mathrm{Eh}$ & $\mathrm{mY}$ & 387.2 & -81.5 & 353.3 & -125.4 \\
\hline Temperature & ${ }^{\circ} \mathrm{C}$ & 23.3 & 23.3 & 24 & 21.9 \\
\hline trichloroethylene & $\mu \mathrm{g} / \mathrm{l}$ & 234.1 & $\mathrm{ND}$ & 109.6 & ND \\
\hline $\begin{array}{c}\text { cis-1,2,- } \\
\text { dichloroethylene }\end{array}$ & $\mu \mathrm{g} / \mathrm{l}$ & 28.2 & $\overline{\mathrm{ND}}$ & $\overline{\mathrm{ND}}$ & $\overline{\mathrm{ND}}$ \\
\hline carbon tetrachloride & $\mu \mathrm{g} / \mathrm{l}$ & 27.5 & $\mathrm{ND}$ & 12.6 & $\overline{\mathrm{ND}}$ \\
\hline chloroform & $\mu \mathrm{g} / \mathrm{l}$ & 3.2 & ND & 2.5 & ND \\
\hline Aluminum & $\mathrm{mg} / \mathrm{l}$ & $<0.116$ & 0.144 & $\overline{\mathrm{NA}}$ & $\overline{\mathrm{NA}}$ \\
\hline Boron & $\mathrm{mg} / \mathrm{l}$ & 0.095 & 0.042 & $\overline{\mathrm{NA}}$ & NA \\
\hline Calcium & $\mathrm{mg} / \mathrm{l}$ & 2.713 & 1.239 & $\mathrm{NA}$ & NA \\
\hline Iron & $\mathrm{mg} / \mathrm{l}$ & 0.159 & 0.231 & $\overline{\mathrm{NA}}$ & $\overline{\mathrm{NA}}$ \\
\hline Magnesium & $\mathrm{mg} / \mathrm{l}$ & 1.068 & 0.197 & $\mathrm{NA}$ & $\mathrm{NA}$ \\
\hline Manganese & $\mathrm{mg} / \mathrm{l}$ & 0.049 & 0.009 & $\overline{\mathrm{NA}}$ & $\mathrm{NA}$ \\
\hline Sodium & $\mathrm{mg} / \mathrm{l}$ & 20.282 & 4.479 & NA & NA \\
\hline Silica & $\mathrm{mg} / \mathrm{l}$ & 4.751 & 1.192 & $\overline{\mathrm{NA}}$ & $\overline{\mathrm{NA}}$ \\
\hline Chloride & $\mathrm{mg} / \mathrm{l}$ & 5 & 41 & $\mathrm{NA}$ & $\overline{\mathrm{NA}}$ \\
\hline Nitrate & $\mathrm{mg} / \mathrm{l}$ & 45 & $<1$ & $\mathrm{NA}$ & $\overline{\mathrm{NA}}$ \\
\hline Sulfate & $\mathrm{mg} / \mathrm{l}$ & 10 & 0.6 & $\overline{\mathrm{NA}}$ & $\overline{\mathrm{NA}}$ \\
\hline
\end{tabular}

Notes:

$\mathrm{NA}=$ Not analyzed; ND = Not detected; Analyses performed by SRTC EST and ADS 
Table 14

NPDES Data

\begin{tabular}{||c|c|c|c|c|c|c|c||}
\hline Parameter & \multirow{2}{*}{ Units } & \multicolumn{7}{|c|}{$\overline{\text { Date }}$} \\
\cline { 3 - 8 } & & $6 / 29 / 98$ & $7 / 98$ & $8 / 13 / 98$ & $9 / 28 / 98$ & $10 / 98$ & $11 / 18 / 98$ \\
\hline Flow & $\mathrm{gpm}$ & 4.06 & $\mathrm{NF}$ & 2.67 & 2.85 & $\mathrm{NF}$ & 4.04 \\
\hline cDCE & $\mu \mathrm{g} / \mathrm{l}$ & 2.8 & $\mathrm{NF}$ & $\mathrm{LTD}$ & 2 & $\mathrm{NF}$ & LTD \\
\hline PCE & $\mu \mathrm{g} / \mathrm{l}$ & $\mathrm{LTD}$ & $\mathrm{NF}$ & LTD & LTD & NF & LTD \\
\hline TCE & $\mu \mathrm{g} / \mathrm{l}$ & $\mathrm{LTD}$ & $\mathrm{NF}$ & LTD & LTD & NF & LTD \\
\hline VC & $\mu \mathrm{g} / \mathrm{l}$ & $\mathrm{LTD}$ & $\mathrm{NF}$ & LTD & LTD & NF & LTD \\
\hline A-TOX & Pass/Fail & Pass & NF & Pass & Pass & NF & Pass \\
\hline
\end{tabular}

Notes:

$\mathrm{NF}=$ No Flow; LTD = Less than detection; All samples taken from sample location TGSC-1; Analyses performed by Shealy Environmental Services, Inc.

\subsubsection{Microbial Results}

All Phase II microbial sampling and analyses were performed prior to start up of the TNX GeoSiphon Cell (TGSC-1), therefore no siphon induced flow was occurring at the time and the only flow through the cell was occurring due to natural water table flow. The samples for microbial analyses were obtained on June 9, 1998, and the analyses were performed on June 10, 1998.

Total microbiological densities measured in the ten samples varied with sample port location (see Table 15). Bacterial densities increased almost one order of magnitude in TGSC-1A and TGSC-1B compared to TCM-2. Degradation of most of the CVOCs and reduction of nitrate also occurs at these locations. After CVOC degradation, wells TGSC-1C through TGSC-1G, the total microbial densities decreased to levels similar to those present in the up-gradient well, TCM-2. Total densities in samples TGSC-1H and TGSC-1 were as high as or higher than those found in the upgradient well and all other sample locations within the well. TGSC-1 has more contact with the outside environment and this may impact its microbial density and the density measured in TGSC-1H. [WSRC-TR-98-00032

Six samples were analyzed during Phase I testing, while the flow rate through the cell was approximately 7.0 gallons per minute. The results obtained during Phase II were higher than those during Phase I for the two sample ports on the upgradient side of the cell (TCM-2 and TGSC-1A) and the down-gradient portion of the well (TGSC-1H and TGSC-1). The density of the two samples pulled within the cell (TGSC-1B and TGSC-1E) were lower than those measured during Phase I (see WSRC-TR-98-00032 Table 13 for comparison). [WSRC-TR-9800032] 
The results for the viable aerobic bacterial counts were two to five orders of magnitude lower than the total direct count densities (see Table 15). The sample results ranged from no growth to $9.50 \mathrm{E}+02 \mathrm{cell} / \mathrm{ml}$. The average density within the cell was approximately equal to the two sample ports outside the cell $(2.47 \mathrm{E}+02$ compared to $2.53 \mathrm{E}+02)$. No growth was observed for TGSC-1B. The results estimate the total number of viable aerobic organisms that oxidize organic chemicals for growth. The dissolved oxygen and Eh levels in the well indicate that conditions for oxidation reactions is not favorable and may explain the low densities measured. In addition, an incorrect temperature was used during the first 24 hours of incubation. This may have also impacted the results.

The diversity results followed a pattern similar, but inversely related, to the results obtained for the total direct counts (see Table 15). TGSC-1A and TGSC-1B had lower diversity measurements than TCM-2. TGSC-1H and TGSC-1 measurements were also lower than those found in TGSC-1C through TGSC-1G. The reduction in enzymatic diversity could be due to an adaptation of the microbial population to utilize specific carbon sources that were produced during the reduction of the chlorinated solvents for sample ports TGSC-1A and 1B. The reduction in enzyme diversity in TGSC-1H and TGSC-1 might be related to TGSC-1 being in direct contact with the atmosphere.

Table 15

Microbial Test Results

\begin{tabular}{|c|c|c|c||}
\hline $\begin{array}{c}\text { Sample } \\
\text { Location }\end{array}$ & $\begin{array}{c}\text { Total Cell Density } \\
(\# / \mathrm{ml})\end{array}$ & $\begin{array}{c}\text { Viable Aerobic } \\
\text { Heterotrophic } \\
\text { Bacteria } \\
(\# / \mathrm{ml})\end{array}$ & $\begin{array}{c}\text { Biolog } \\
\text { Measurement } \\
\text { (\# Positive wells) }\end{array}$ \\
\hline TCM-2 & $5.65 \mathrm{E}+04$ & $1.45 \mathrm{E}+02$ & 70 \\
\hline TGSC-1A & $2.73 \mathrm{E}+05$ & $9.50 \mathrm{E}+02$ & 52 \\
\hline TGSC-1B & $3.96 \mathrm{E}+05$ & no growth & 32 \\
\hline TGSC-1C & $6.87 \mathrm{E}+04$ & $7.50 \mathrm{E}+01$ & 65 \\
\hline TGSC-1D & $3.41 \mathrm{E}+04$ & $4.65 \mathrm{E}+02$ & 64 \\
\hline \hline TGSC-1E & $1.10 \mathrm{E}+04$ & $2.90 \mathrm{E}+02$ & 84 \\
\hline TGSC-1F & $7.44 \mathrm{E}+04$ & $1.00 \mathrm{E}+02$ & 9 \\
\hline TGSC-1G & $6.84 \mathrm{E}+04$ & $8.00 \mathrm{E}+01$ & 53 \\
\hline TGSC-1H & $1.66 \mathrm{E}+05$ & $1.50 \mathrm{E}+01$ & 62 \\
\hline TGSC-1 & $1.32 \mathrm{E}+06$ & $3.60 \mathrm{E}+02$ & \\
\hline
\end{tabular}


Ten water samples located upgradient, down-gradient and within the GeoSiphon cell were analyzed for microbiological parameters during natural flow conditions. The results showed the density of microorganisms increased where the reduction of chlorinated solvents and nitrate was occurring within the cell while the enzymatic diversity of the microbes in this area was reduced. The reduction in enzymatic diversity was probably due to adaptation of the microbial population to utilize specific carbon sources that were produced during the reduction of the chlorinated solvents. Samples taken from points within the cell where most of the chlorinated solvents were reduced indicated that the density and diversity of microorganisms returned to levels measured upgradient of the GeoSiphon cell.

\section{[SRT-EST-98-145]}

\subsubsection{Air Chamber Gas Results}

Two samples from the air chamber were taken on August 24, 1998, and the analyses were performed on August 25, 1998. During this period the TNX GeoSiphon Cell (TGSC-1) was operating under the third siphon line configuration (see Table 6 for a description of this configuration) at flow rates ranging from 0 to $2 \mathrm{gpm}$. Table 16 presents the summary gas composition, and Appendix $G$ presents the detailed gas analyses as received from the analytical subcontractor, Microseeps. Offgassing within the siphon line consisted primarily of nitrogen and hydrogen. The oxygen levels were depleted due to the reaction of oxygen with the zero valent iron within TGSC-1 (see section 3.2). The analytical oxygen level of $4.88 \% / \mathrm{v}$ may in fact be over stated due to an incomplete purge of atmospheric air from the sample line prior to sample collection (see section 6.1 for a description of the air chamber sampling method). An oxygen level of $2.5 \% / v$ was estimated based upon the Phase I aqueous dissolved oxygen (DO) results and Henry's Law constant for oxygen. This mixture of gas as characterized within Table 15 is outside the flammability envelope for both.hydrogen and methane (i.e., it is not a flammable gas mixture). However the addition of sufficient oxygen to the gas mixture could produce a flammable gas mixture, which could burn with the addition of an ignition source. Therefore collection and subsequent disposition of the gas mixture must be performed in a manner that precludes such an occurrence. 
Table 16

Air Chamber Summary Gas Composition

\begin{tabular}{|c|c|}
\hline Component & $\begin{array}{c}\text { Percent by Volume } \\
(\% / \mathrm{v})\end{array}$ \\
\hline $\mathrm{N}_{2}$ & 46.24 \\
\hline $\mathrm{H}_{2}$ & 40.99 \\
\hline $\mathrm{O}_{2}{ }^{1,2}$ & $4.88^{1} / 2.5^{3}$ \\
\hline $\mathrm{CH}_{4}{ }^{1}$ & 1.97 \\
\hline $\mathrm{H}_{2} \mathrm{O}^{3,4}$ & $\sim 2$ \\
\hline $\mathrm{Ar}^{3}$ & $\sim 2$ \\
\hline Total & 98.08 \\
\hline
\end{tabular}

Average analytical value from Microseeps analysis

${ }^{2}$ The Microseeps analytical oxygen level may be overstated due to incomplete purge of the sample line

${ }^{3}$ Estimated values based upon vapor pressure for water; and Phase I aqueous DO results and $\mathrm{K}$ for oxygen; and $\mathrm{K}$, atmospheric composition, and ratio with nitrogen values for argon

${ }^{4}$ The water value may be underestimated, since the sub-atmospheric pressure was not considered 


\subsection{CONCLUSIONS AND RECOMMENDATIONS}

\subsection{CONCLUSIONS}

GeoSiphon Cells (patent pending) are systems to passively induce contaminated groundwater flow through in situ or ex situ permeable treatment media at an accelerated rate by utilizing a siphon between two points of natural hydraulic head difference, without the need for mechanical pumps. The TNX GeoSiphon Cell (TGSC-1) was built as a Pre-Siphon Treatment Cell Configuration (Table 1 and Figure 1). It is essentially a large diameter well, which contains granular cast iron (the treatment media) in place of gravel pack. Contaminated groundwater flow through the granular cast iron in the treatment cell is passively induced by use of a siphon from the cell to the X-08 outfall ditch. The flow is induced by the natural hydraulic head difference between the cell and the X-08 outfall ditch. The granular cast iron reduces the chlorinated volatile organic compounds (CVOCs) to ethane, ethene, methane, and chloride ions (see section 3.2 for a description of zero valent iron enhanced abiotic degradation). The treated water is subsequently discharged through the X-19 outfall to the X-08 outfall ditch, which flows into the Savannah River.

Testing of four different siphon line configurations was conducted during Phase II testing from June 18, 1998 to September 4, 1998, and a "one-day minimum flushing velocity test" was conducted on November 13, 1998.

The first three siphon line configuration consisted of approximately 1032 feet of $1-1 / 2$ inch pipe from the cell to the Savannah River. The first three configurations differed in the line grades for the first 305 feet of pipe, in the use of an air chamber or not, and in the location of the air chamber in the line, if utilized. All three configurations had the last 727 feet of line laid directly on the ground surface within the X-08 outfall ditch, which resulted in localized high points at various points within this portion of the line.

While each of the first three successive configurations tested demonstrated improvement, operation of each resulted in initial higher flow followed by diminishing flow over a matter of hours to essentially zero. Re-priming was required to initiate operation again for each configuration. It was determined that degassing and subsequent gas entrapment, within those portions of the siphon line not influenced by the air chamber, if used, was the cause of eventual siphon breakage. In particular degassing and gas entrapment, within localized high points in that portion of the line within the X-08 outfall ditch, were identified as the problem. Even during repriming events for these configurations some gas remained entrapped within that portion of the line. 
The fourth siphon line configuration was the same as that of the third, except that the 727 feet of line within the X-08 outfall ditch, which had localized high points, was removed. It consisted of 305 feet of $1-1 / 2$ inch pipe on a consistent engineered slope with an air chamber. The air chamber was at the crest of the siphon line with the up-gradient leg of the line sloping upward to the air chamber at 1:100 and the down-gradient leg of the line sloping downward away from the air chamber at $\sim 22-1 / 2^{\circ}$. Operation of the fourth siphon line configuration resulted in continuous, consistent operation with flow rates consistent with calculated values (see Figure 25). Repriming was not required, however air chamber water recharging was required on a periodic basis. This siphon line configuration with air chamber was able to maintain full siphon line flow by removal of gas bubbles from in its entire 305-foot length.

While continuous, consistent siphon line operation, relying upon minimum flushing velocity rather than an air chamber to maintain full flow, was never achieved during this testing, several important observations pertinent to future potential successful use of this method were made. It was concluded that in order for minimum flushing velocity to potentially be viable as a method of removing gas from the siphon line, in lieu of air chamber usage, line discontinuities and localized high points, which promote bubble accumulation, agglomeration, and potentially entrapment must be eliminated. One continuous pipe without fittings placed on an engineered grade with one crest would probably be the optimal configuration to employ minimum flushing velocity as the means for removing gas from the siphon line. Alternately one continuous larger diameter pipe without fittings on the upward leg of the siphon line followed by a smaller diameter pipe utilized for the crest and downward leg of the siphon line could be used. This would minimize head loss. However the fitting between the two pipes could not have an abrupt change in inside diameter, which would promote the accumulation and agglomeration of bubbles. Additionally, the inter-related parameters of siphon line diameter, fluid flow velocity, and bubble size appear to be the parameters, which influence the ability to remove gas from a siphon line through the use of a minimum flushing velocity. All three parameters must be considered when designing a siphon line to maintain full flow through the use of minimum flushing velocity.

An air chamber at the siphon crest to remove gases from the siphon line in order to maintain full flow in the line was successfully utilized. The potential alternate method for maintenance of full flow in the siphon line is the minimum flushing velocity method. Minimal testing of this potential method-was also conducted.=Additional testing=would be-required-in=order-to determine if the use of minimum flushing velocity could be successful.

The analytical data produced during Phase II was consistent with the Phase I data documented in WSRC-TR-98-00032. There were only two significant differences between the Phase I and Phase II analytical data. During Phase I testing, manganese concentrations significantly increased over influent concentrations at all flow rates followed by lower but still elevated concentrations at the cell's effluent. The one Phase II manganese data point collected during no flow conditions indicates a decrease in manganese effluent concentrations over influent 
concentrations. The one Phase II TCE influent sample (TCM-2) collected under condition of flow $(2.56 \mathrm{gpm})$ had a concentration of approximately $110 \mathrm{ppb}$ that was approximately half the typical influent recorded during Phase I. This could indicate that overall plume concentrations are declining. Other Phase II analytical items of note include:

- All effluent PCE, TCE, CT, CTM, and vinyl chloride (VC) concentrations were less than the detection limits.

- All effluent cDCE concentrations were less than $3 \mu \mathrm{g} /$.

- All Ceriodaphnia Dubia, 48-hour, Static, Acute Toxicity Tests at an in stream waste concentration (IWC) of $33 \%$ (i.e. $33 \%$ GeoSiphon effluent and $67 \%$ dilution water) had passing results (i.e. the GeoSiphon effluent is not considered toxic).

- Microbial density increased in those areas where TCE and nitrate reduction was actively occurring, while the enzymatic diversity of the microbes in those areas was reduced. Microbial density and diversity returned to up-gradient levels in those areas where no such reduction was occurring.

- Offgassing within the siphon line consisted primarily of nitrogen and hydrogen with depleted oxygen levels. This mixture of gas as characterized within Table 16 is outside the flammability envelope for both hydrogen and methane (i.e. it is not a flammable gas mixture). However, the addition of sufficient oxygen to the gas mixture could produce a flammable gas mixture, which could burn with the addition of an ignition source. Therefore, collection and subsequent disposition of the gas mixture must be performed in a manner that precludes such an occurrence.

\subsection{RECOMMENDATIONS}

Based upon the favorable results to date and the fact that a second TNX GeoSiphon Cell (TGSC2) was installed in September, 1998, the following recommendations are made:

- New siphon lines should be constructed for both TGSC-1 and TGSC-2 based upon the information gained from the currently completed portion of Phase II testing. The new siphon lines should be installed consistent with Figures 30,31, and 32, which provide the siphon line map for both TGSC-1 and TGSC-2, the TGSC-1 siphon line profile, and the TGSC-2 siphon line profile, respectively. A larger air chamber should be provided to lengthen the period of time required between air chamber recharging events. It is recommended that at least a 200 -gallon air chamber be provided for each siphon line. The end of the new siphon line should be installed within the X-08 outfall ditch in a location that provides more head differential than provided by the previous installation. The proposed location has an estimated normal water elevation of approximately $\mathbf{8 8 . 8 2}$ $\mathrm{ft}-\mathrm{msl}$ (i.e., when water in the ditch at this location is not backed up due to the Savannah River stage). This will provide approximately 5 feet of head differential to drive the system. It has been calculated that this head differential will be capable of producing

$$
\text { Page } 51 \text { of } 92
$$


approximately $9.5 \mathrm{gpm}$ of flow through TGSC-1 (Figure 33) and $9.4 \mathrm{gpm}$ through TGSC2 (Figure 34). For completeness of information, Figures 35 and 36 have been provided that present the pressure/vacuum profiles for the TGSC-1 and TGSC-2 siphon lines, respectively, based upon the conditions shown on the associated profiles (Figures 31 and 32).

- Phase II testing should continue with Phase II Dual Cell Testing. During Phase II Dual Cell Testing, both TGSC-1 and TGSC-2 should be operated, and emphasis should be placed upon the following:

- Offgas generation rates and composition

- Zone of influence and capture associated with dual cell operation

- Minimum flushing velocity testing to determine if the use of an air chamber can be eliminated

- Impact of Savannah River stage on the flow rates (noting that the Savannah River stage has the historic potential of impacting the head at the end of the siphon line approximately 27 percent of the time) 


\section{REFERENCES}

EPA/600/F-97/008. Permeable Reactive Subsurface Barriers for the Interception and Remediation of Chlorinated Hydrocarbon and Chromium (VI) Plumes in Ground Water. U. S. EPA Remedial Technology Fact Sheet

ETI Reference: 31054.10, EnviroMetal Technologies, Inc., "Feasibility Study Report, CVOC Iron Degradation Study Using Groundwater from the TNX Area, Savannah River Technology Center, Aiken, South Carolina," July 1996.

Gibson, A. H. (1961). Hydraulics and Its Applications, Constable \& Company LTD, London.

Gillham, R. W. and O'Hannesin, S. F. (1994). "Enhanced Degradation of Halogenated aliphatics by Zero-Valent Iron," Ground Water, Vol. 32, No. 6, November-December, 1994, pp. 958-967.

Loitz, D. B., de Steiguer, A. L., and Broz, W. R. (1990). "Siphon Quenches," Civil Engineering, Vol. 60, No. 8, August, 1990, pp. 44-46.

Mathur, J. (1990). "Draw some Help from Hydraulic Grade Lines," Chemical Engineering Progress, October, 1990, pp. 50-54.

O'Hannesin, S. F. and Gillham, R. W. (1998). "Long-term Performance of an In situ "Iron Wall" for Remediation of VOCs," Ground Water, Vol. 36, No. 1, pp. 164-170. Q-TPL-T-00004, Phifer, M. A., "Scoping Test Plan Phase II TNX GeoSiphon Cell Demonstration,"
May 29, 1998.

SRT-ESS-96-365, Phifer, M. A., "Permeable Wall Laboratory Study Final Report," August 6, 1996.

SRT-EST-98-145, Berry, C. J., "Subject: Microbial Analyses of the GeoSiphon Cell 6/9/98," July
20,1998.

TNX GeoSiphon Cell Phase II Industrial Wastewater Treatment Facility Construction Permit Application Package. 


\section{REFERENCES (continued)}

Tratnyek, P. G., Johnson, T. L., Scherer, M. M., and Eykholt, G. R. (1997). "Remediating Ground Water with Zero-Valent Metals: Chemical considerations in Barrier Design," Ground Water Monitoring Review, Fall 1997, pp. 108-114.

WSRC Manual 1Q, Procedure QAP 2-3

WSRC Manual L1, Procedure 7.10

WSRC Manual L14.1, Procedure 2-76

WSRC-TR-98-00032, Phifer, M. A., Sappington, F. C., and Denham, M. E., "TNX GeoSiphon Cell (TGSC-1) Phase I Deployment / Demonstration Final Report (U)," February, 27, 1998. 


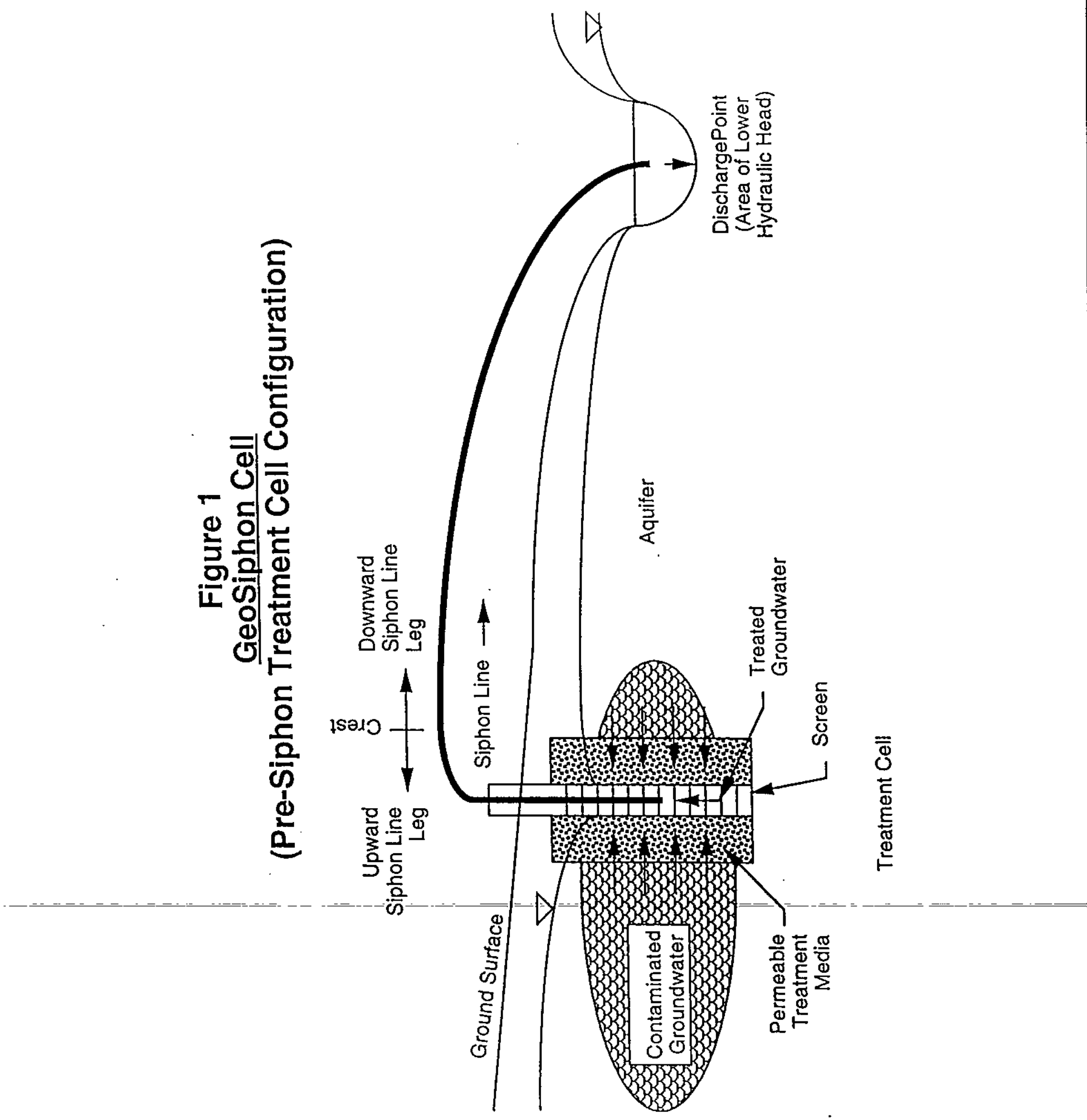




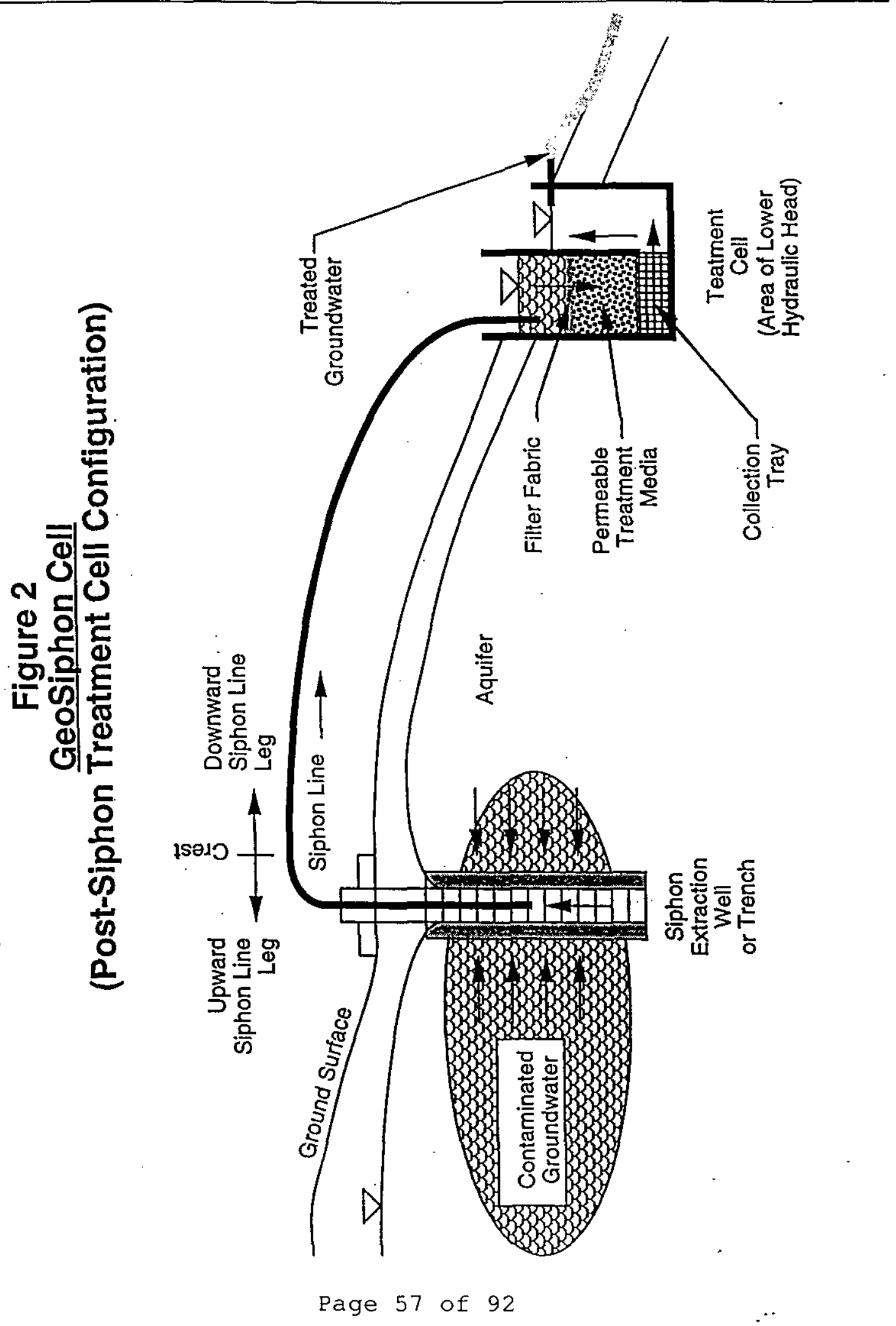




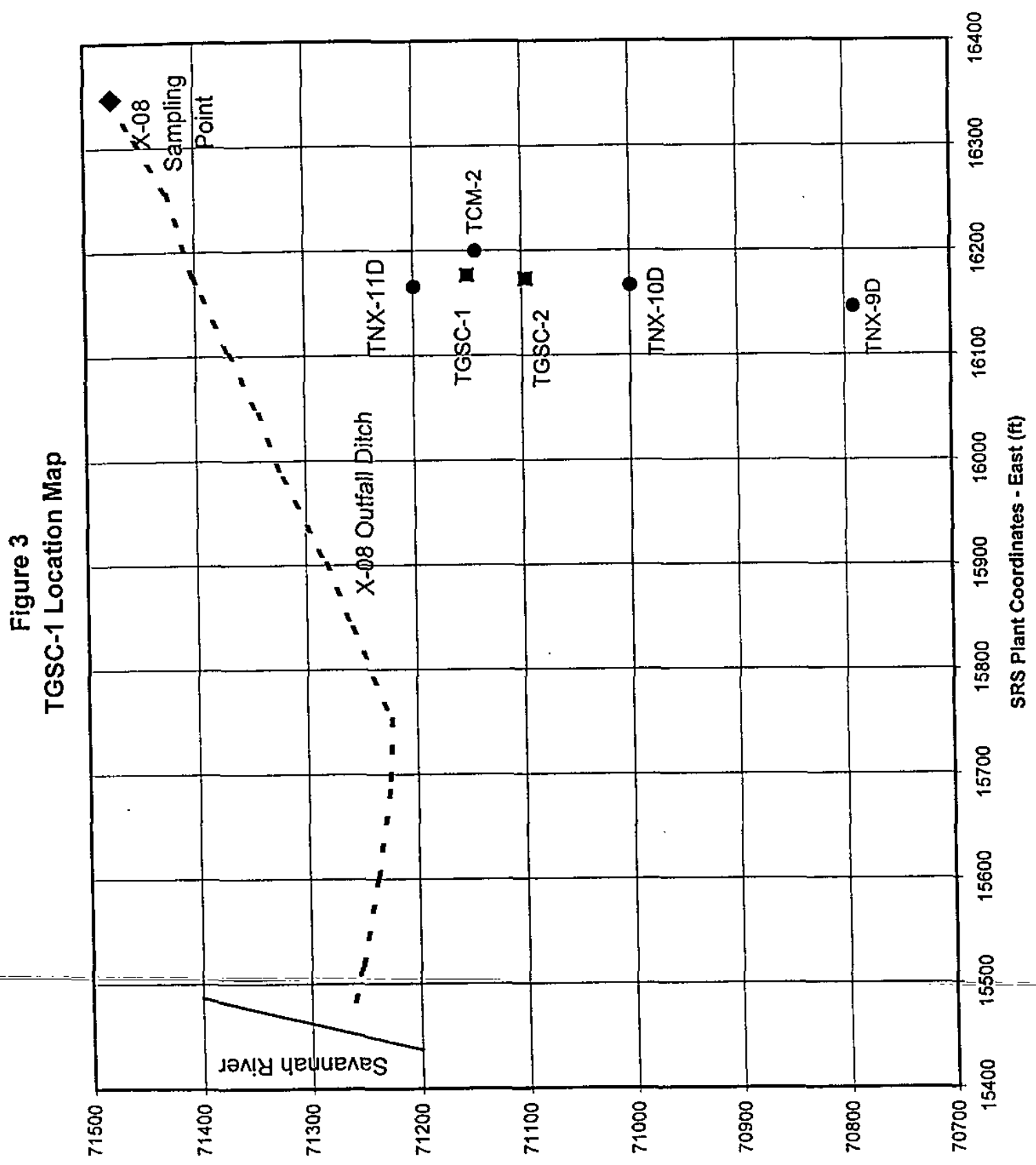

(4) 4นON - sojeu!plooj jueld s\&S 
Figure 4

TNX GeoSiphon Cell

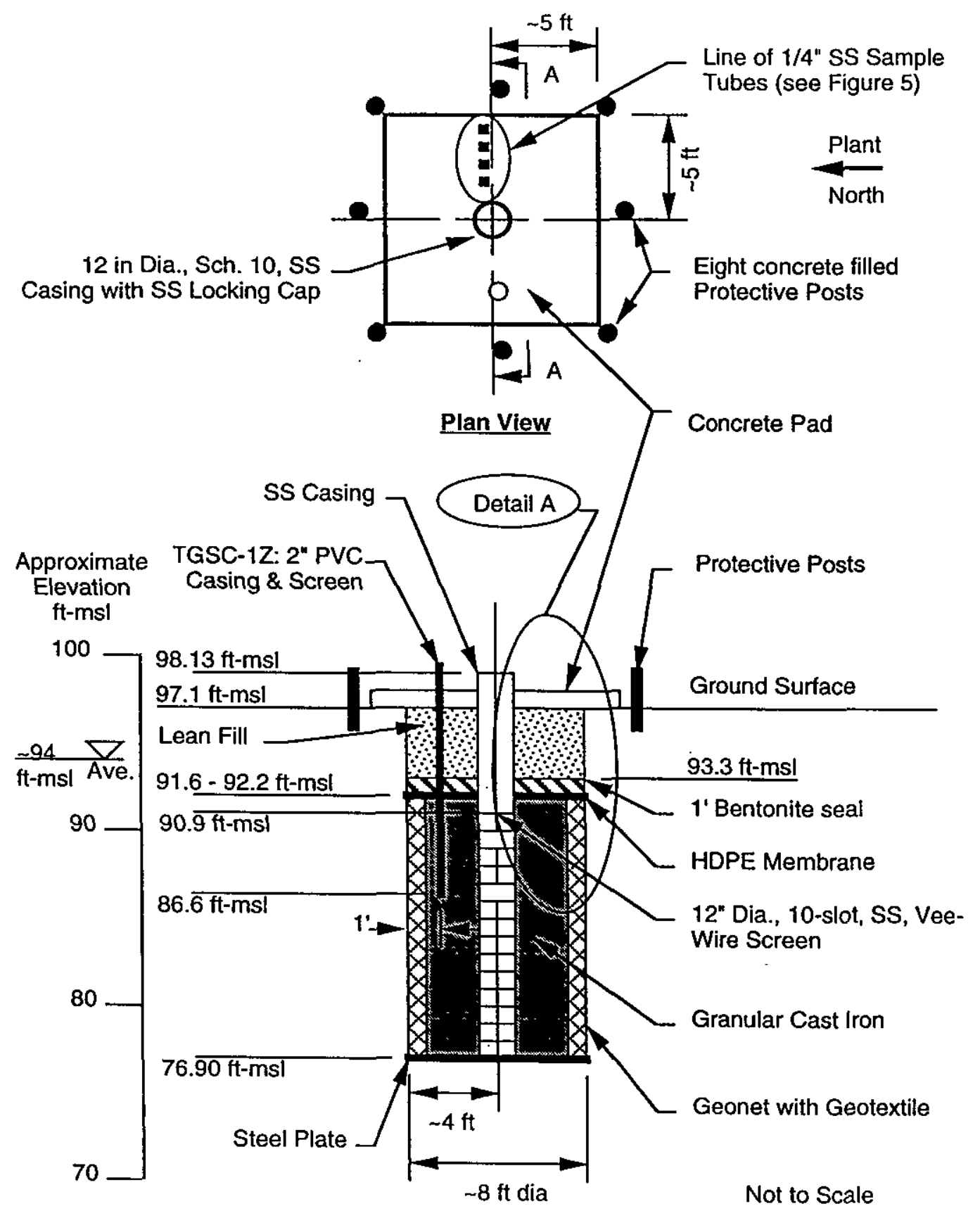

Section A-A

Page 59 of 92 
Figure 5

TNX GeoSiphon Cell

SS Sample Tube Locations \& Designations

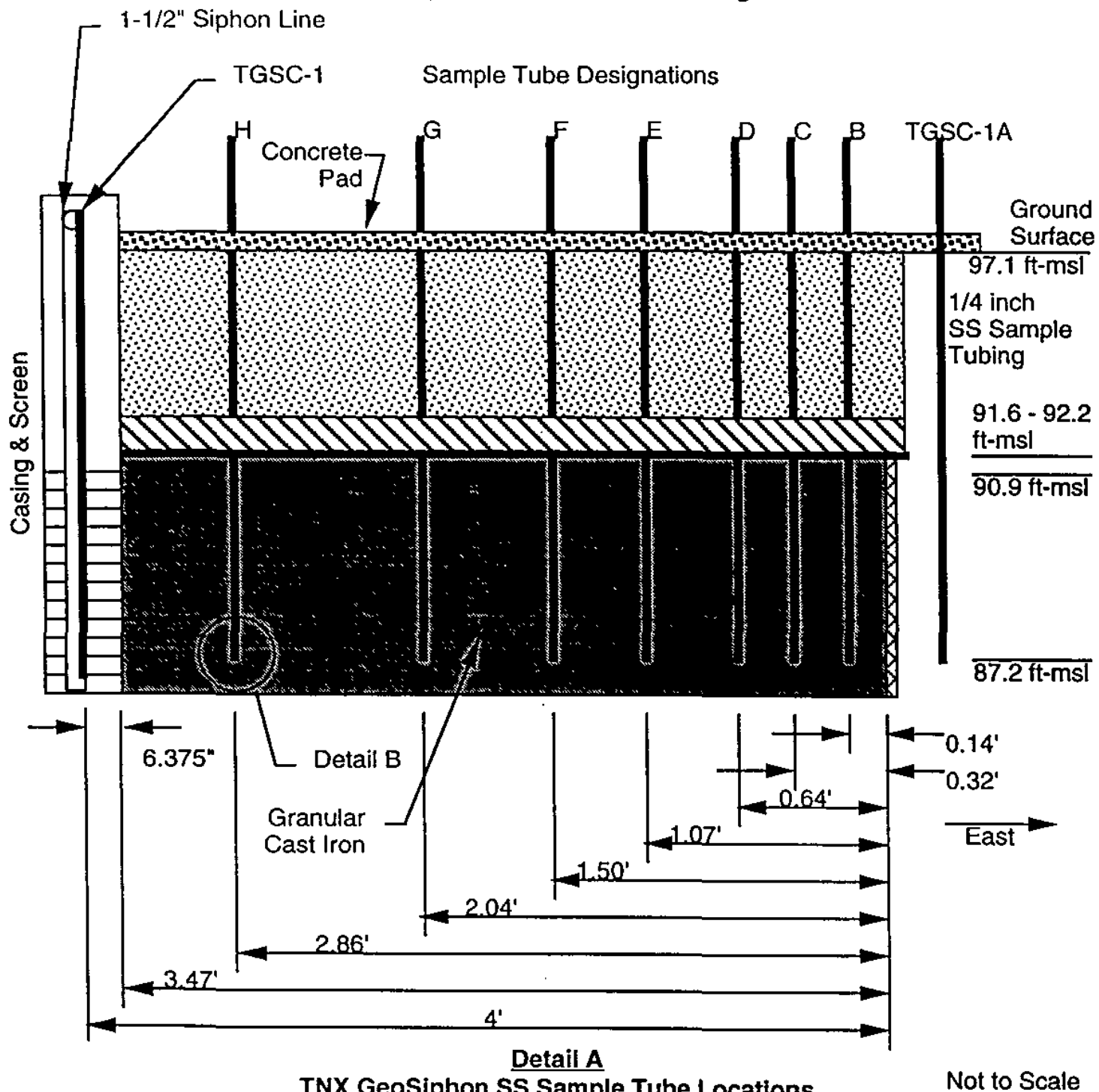

TNX GeoSiphon SS Sample Tube Locations

Not to Scale

4 lines of $1 / 16^{\prime \prime}$ diameter holes, with 25 holes per line, with each line of holes at $90^{\circ}$ to the adjacent line, for a total of 100 holes

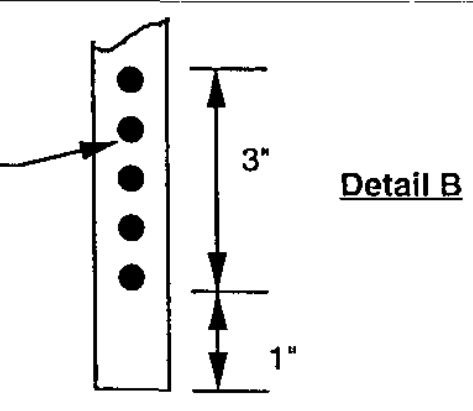

$$
\text { Page } 60 \text { of } 92
$$




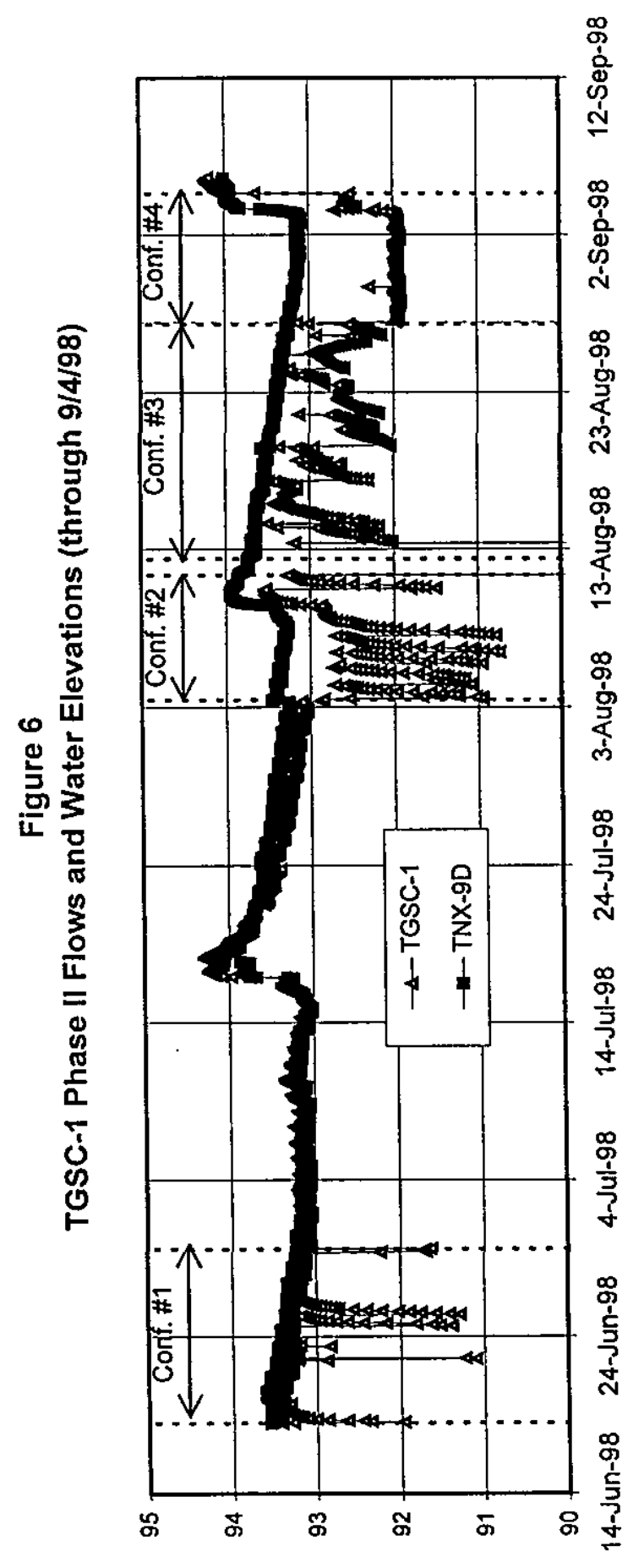

(ןsu-भ) นо!ұеләэз дәјем

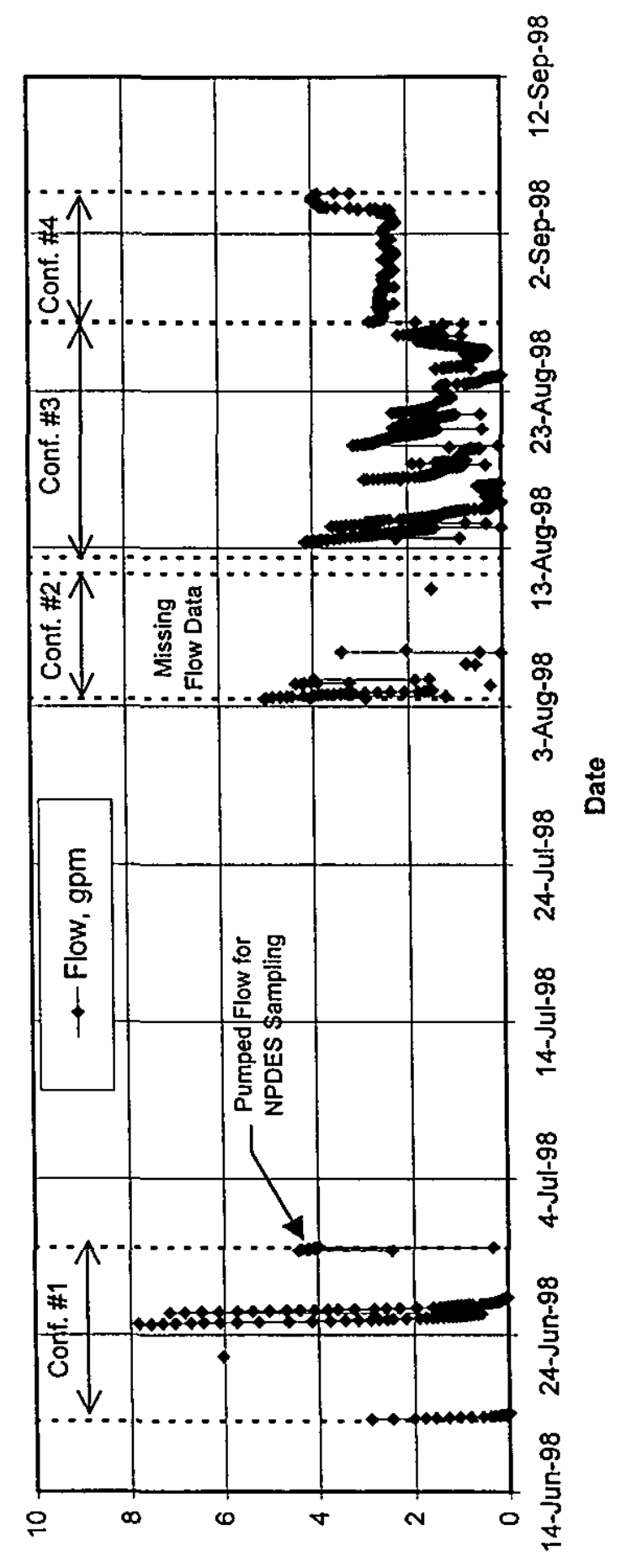

(ud6) MOF-

Page 61 of 92 


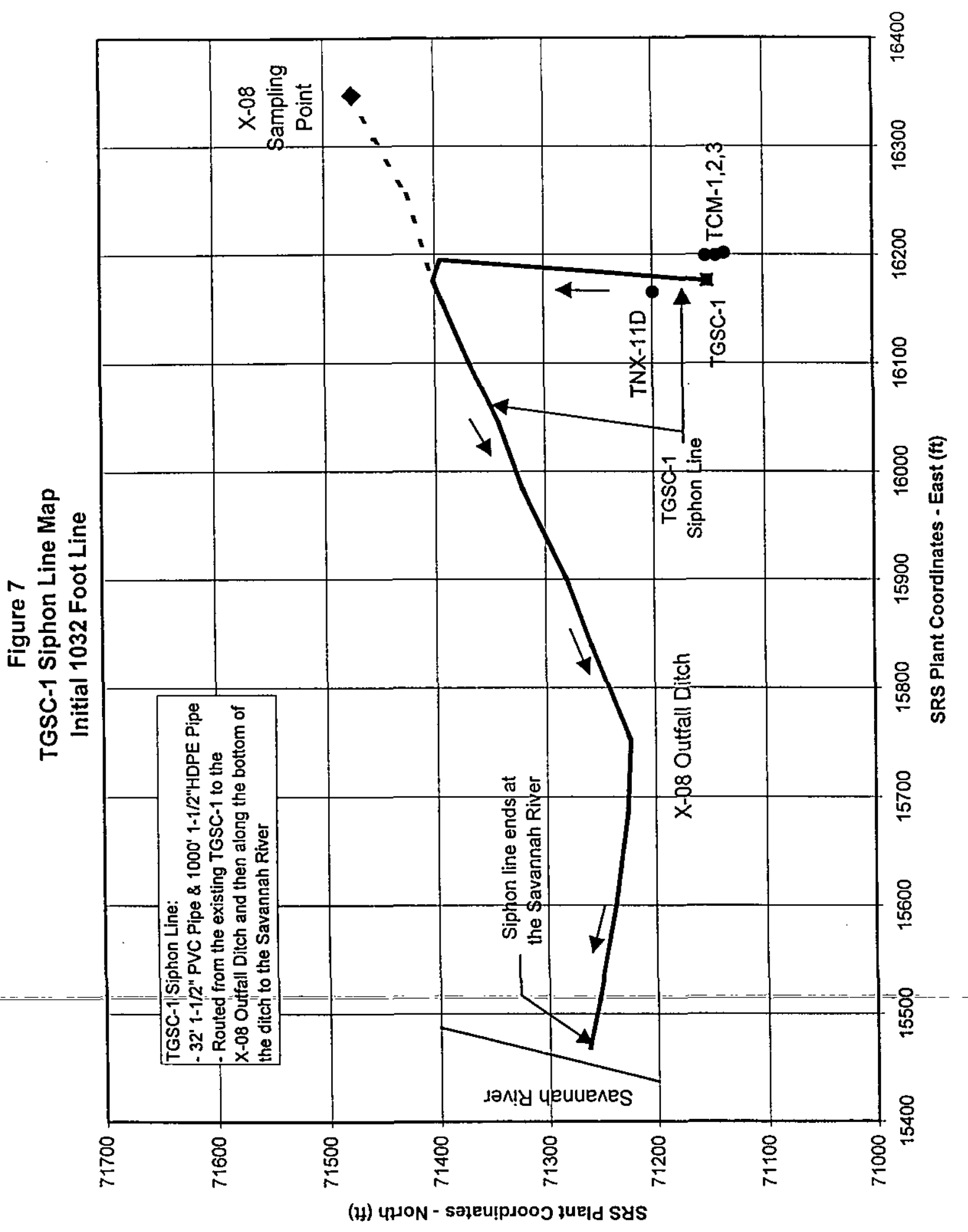

Page 62 of 92 


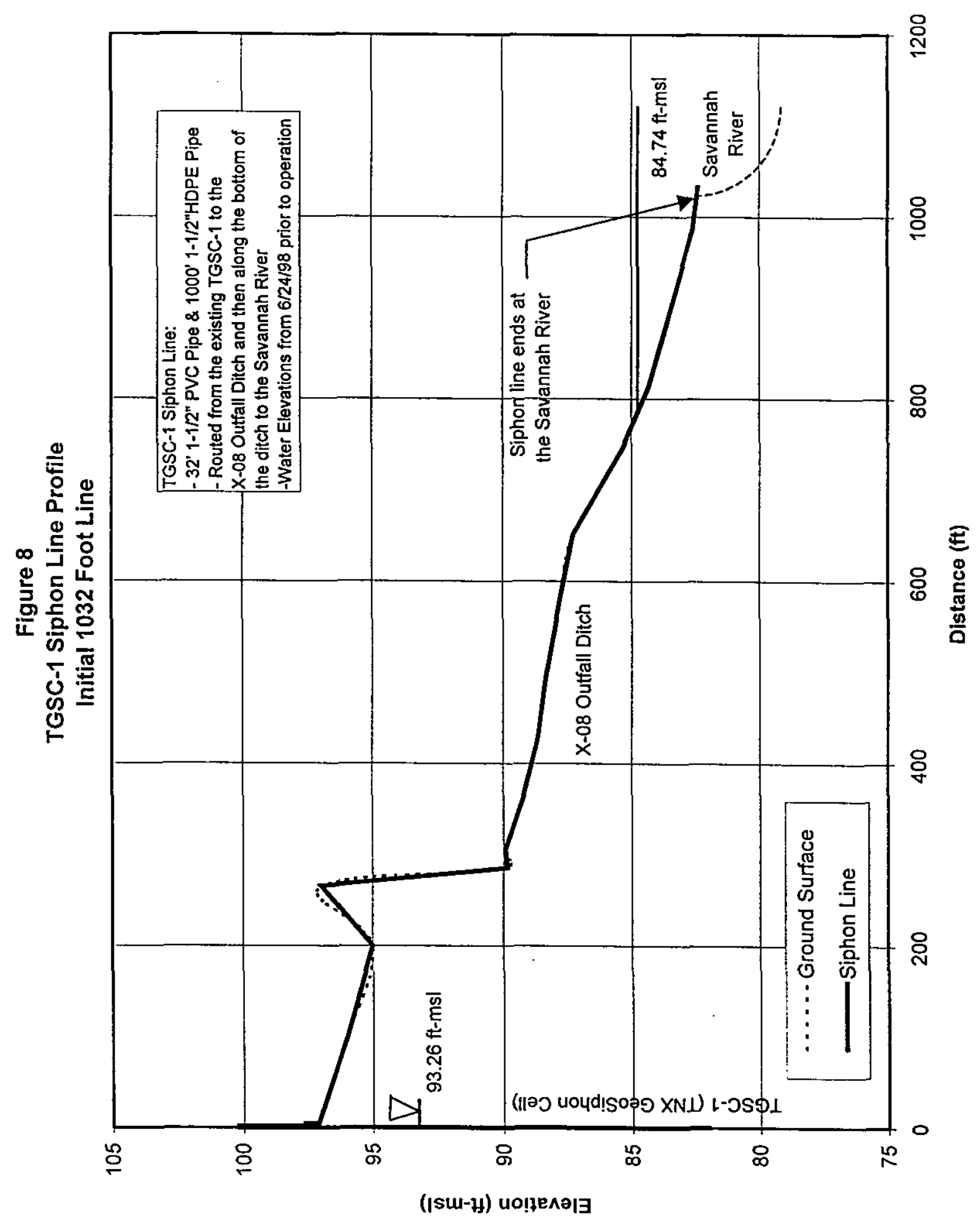

Page 63 of 92 


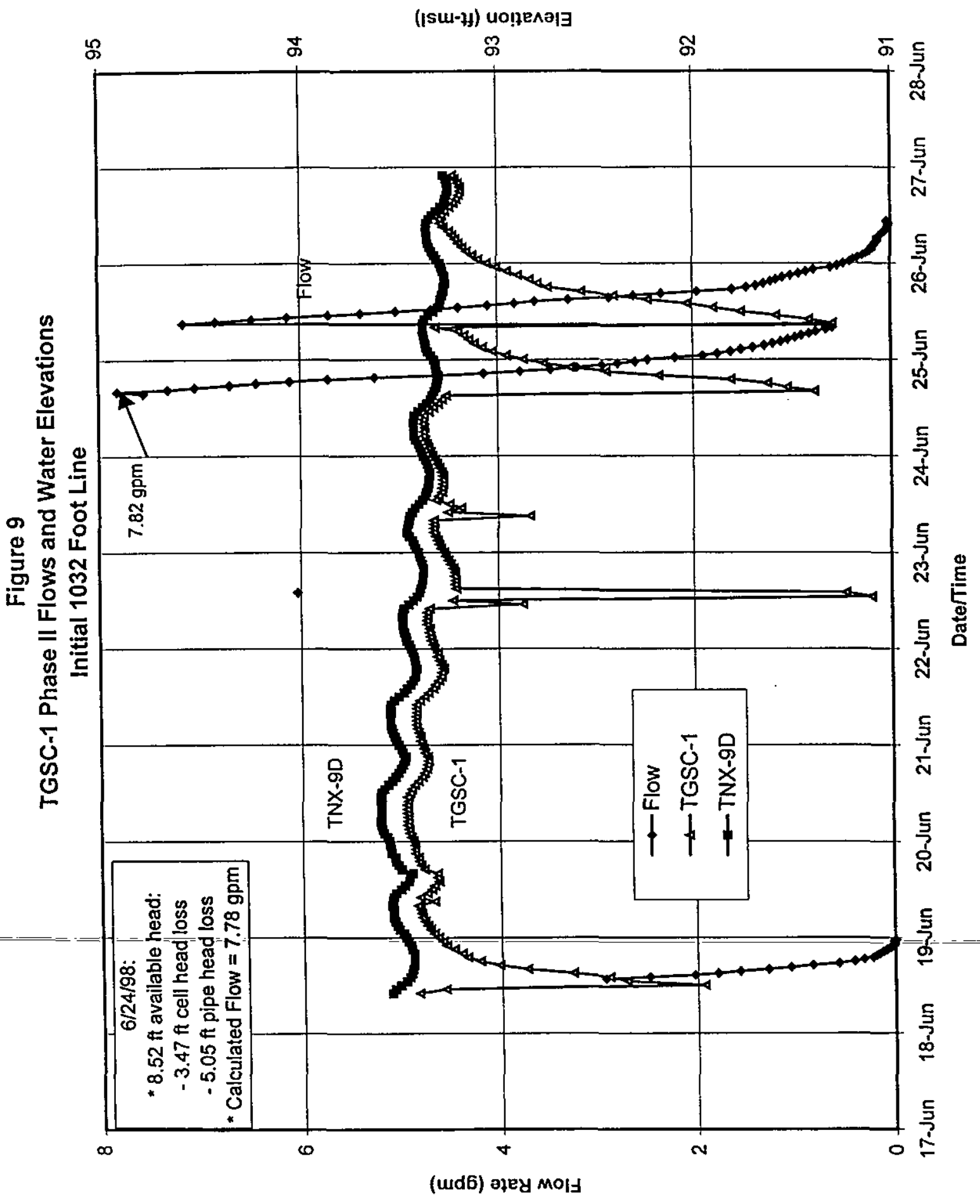

Page 64 of 92 


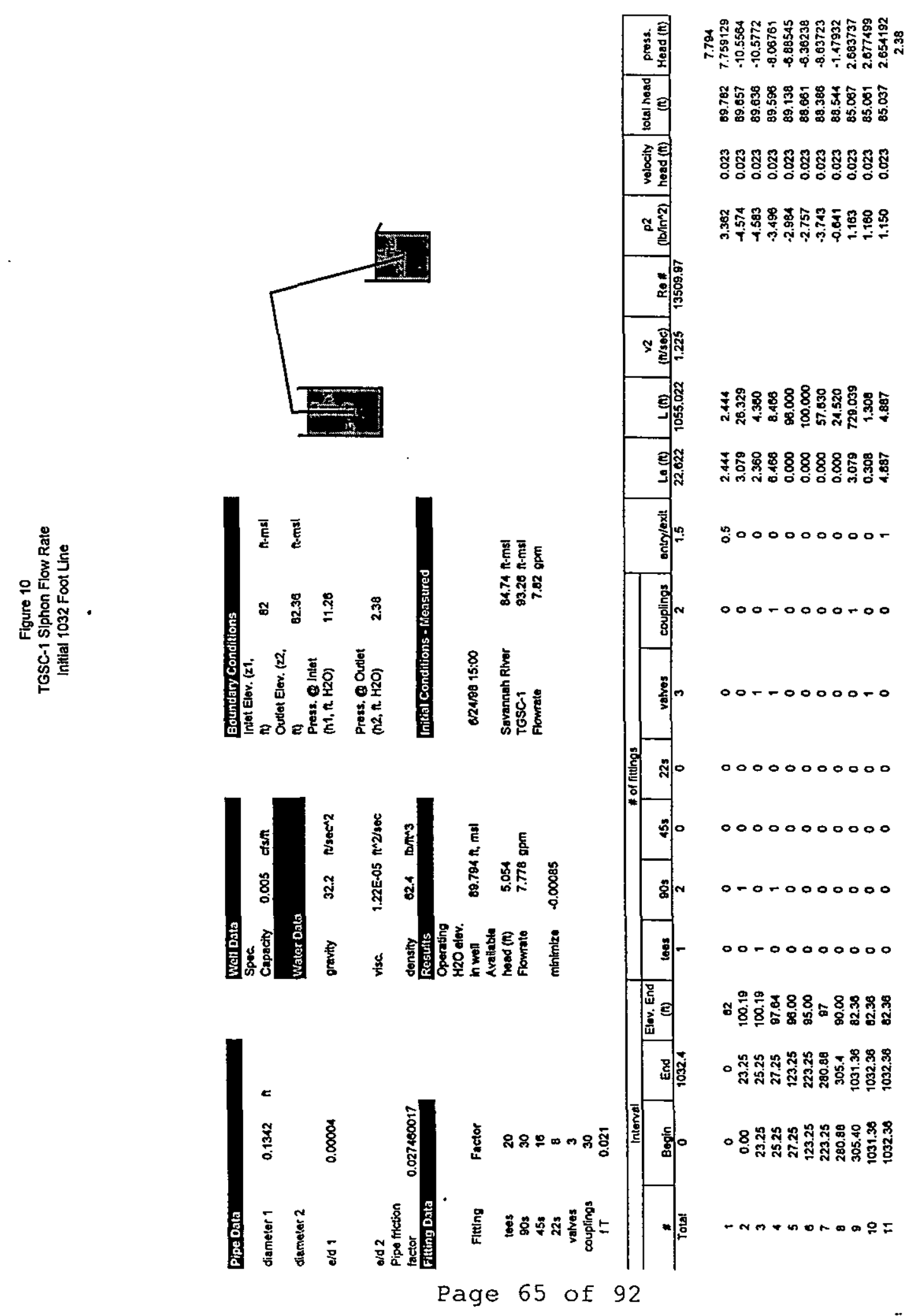




TGSC-1 Phase II Report WSRC-TR-98-00432, Rev. $0 \quad$ January 12, 1999

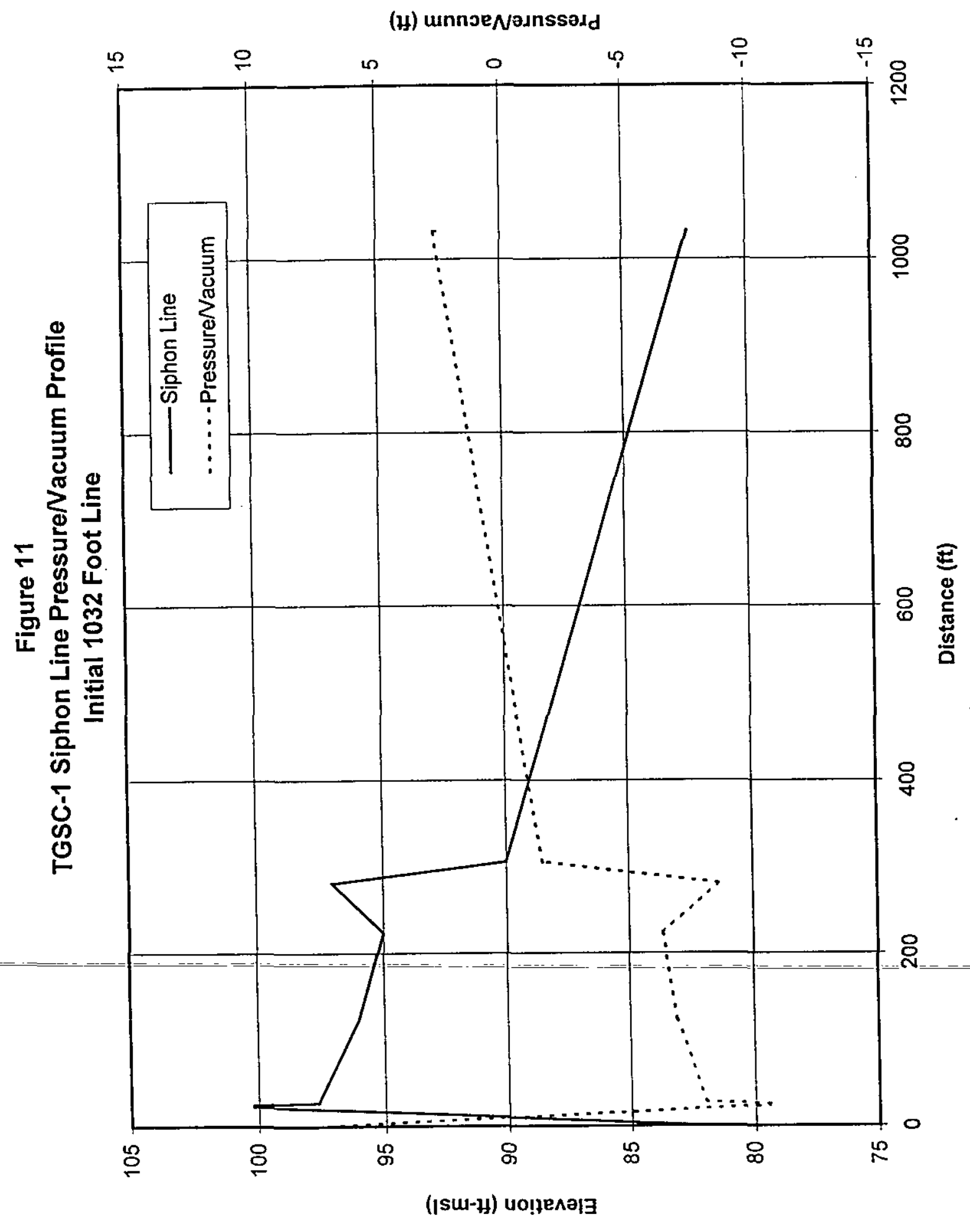

Page 66 of 92 
Figure 12

\section{AIR CHAMBER}

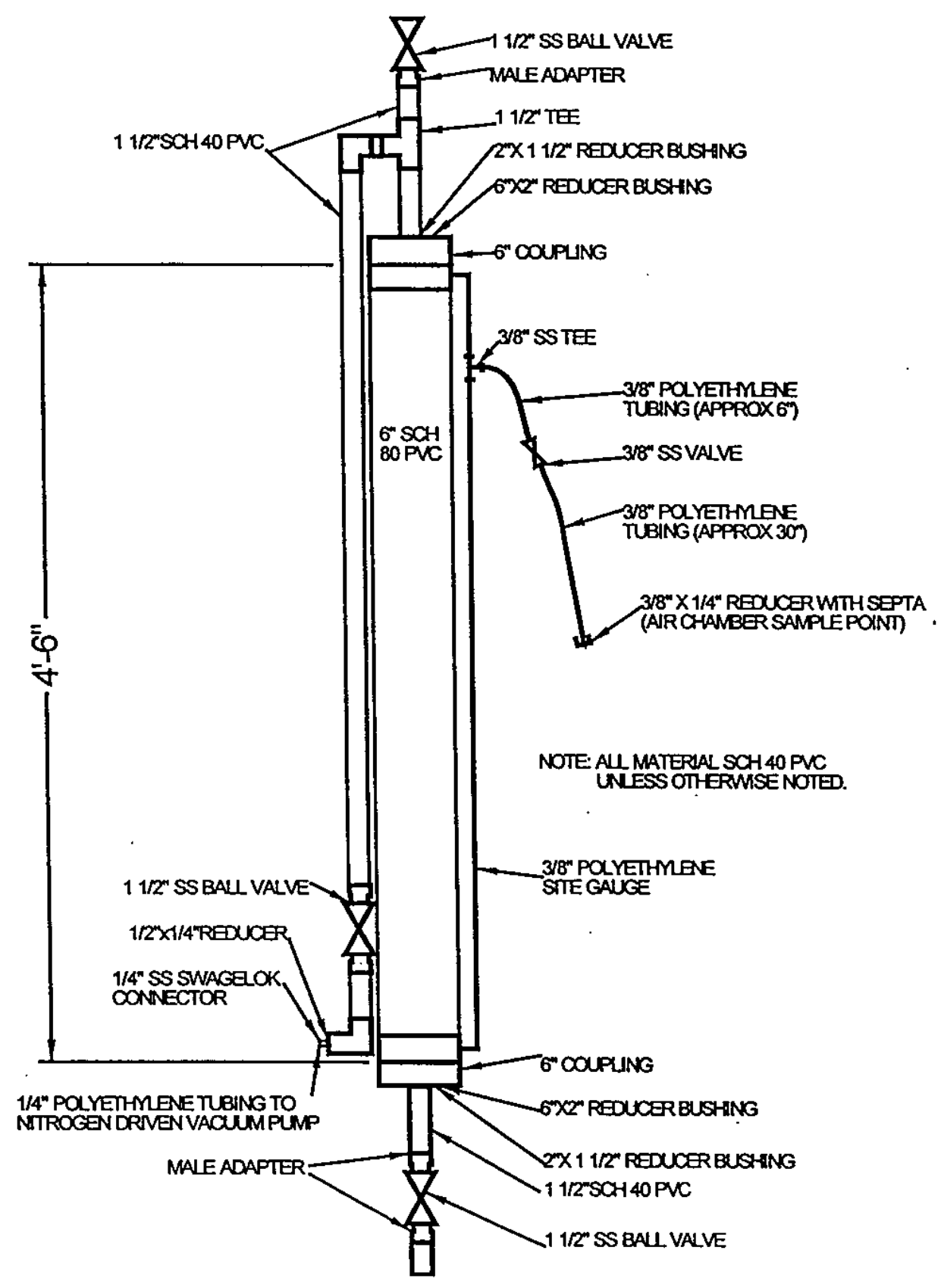

Page 67 of 92 


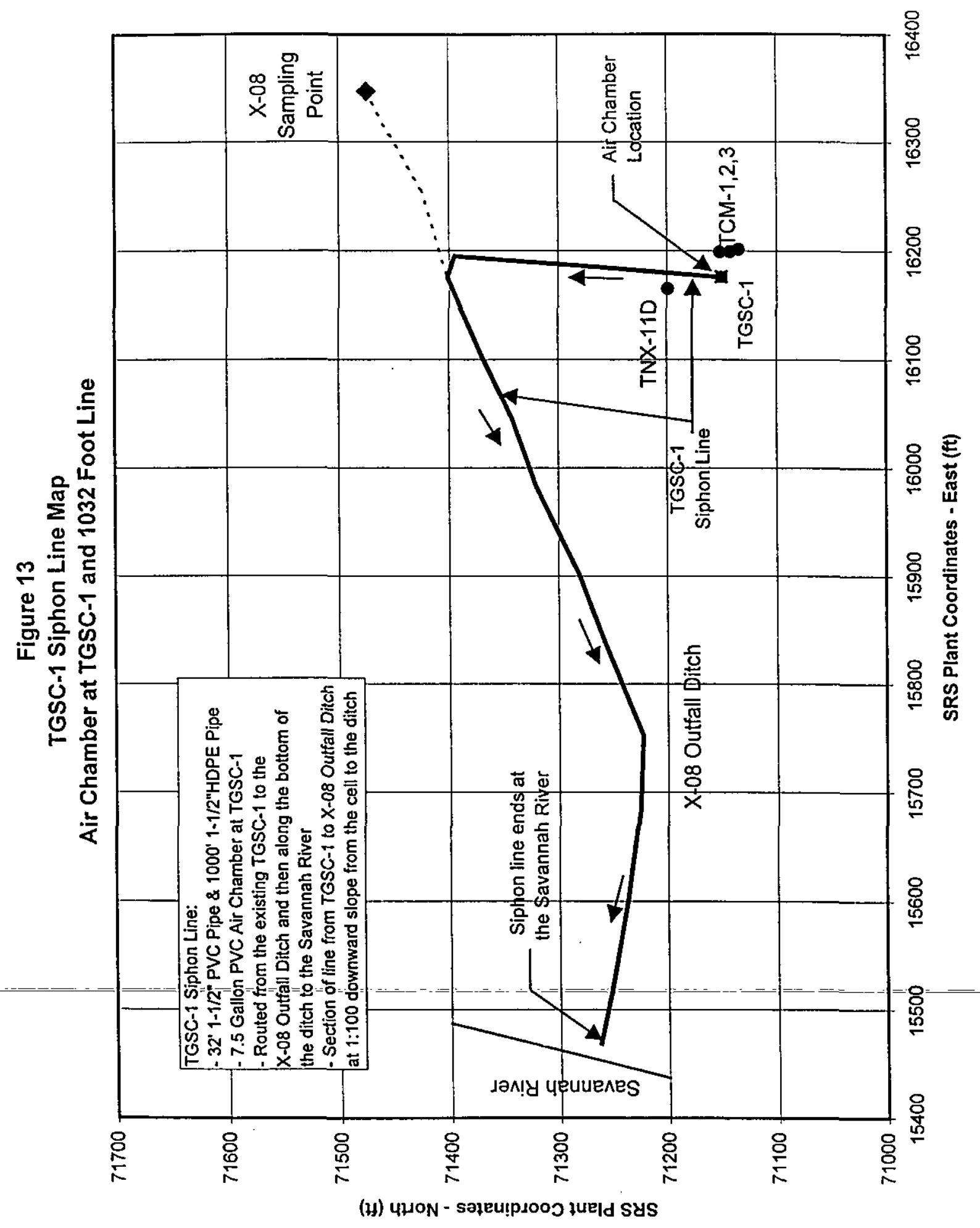

Page 68 of 92 


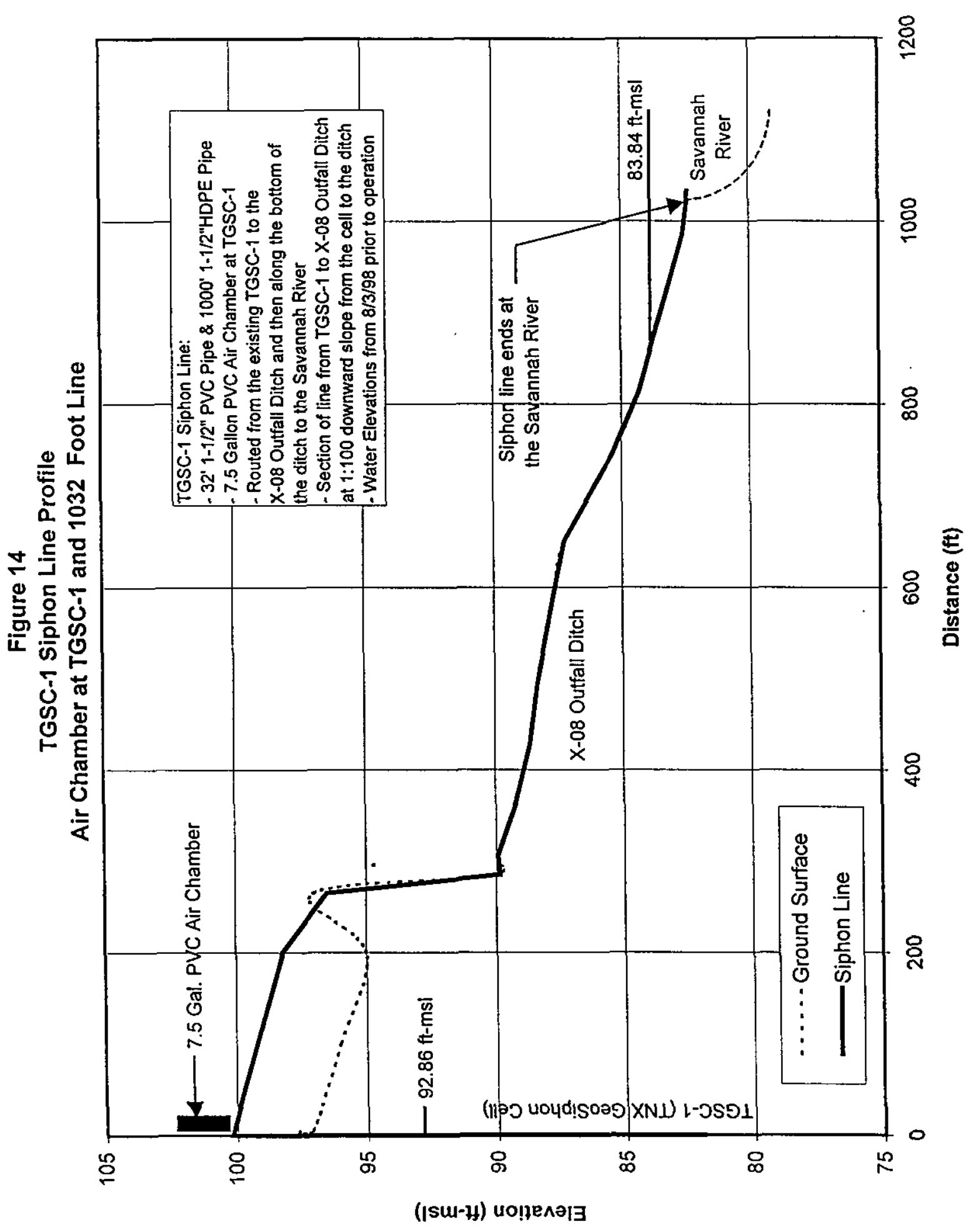

Page 69 of 92 


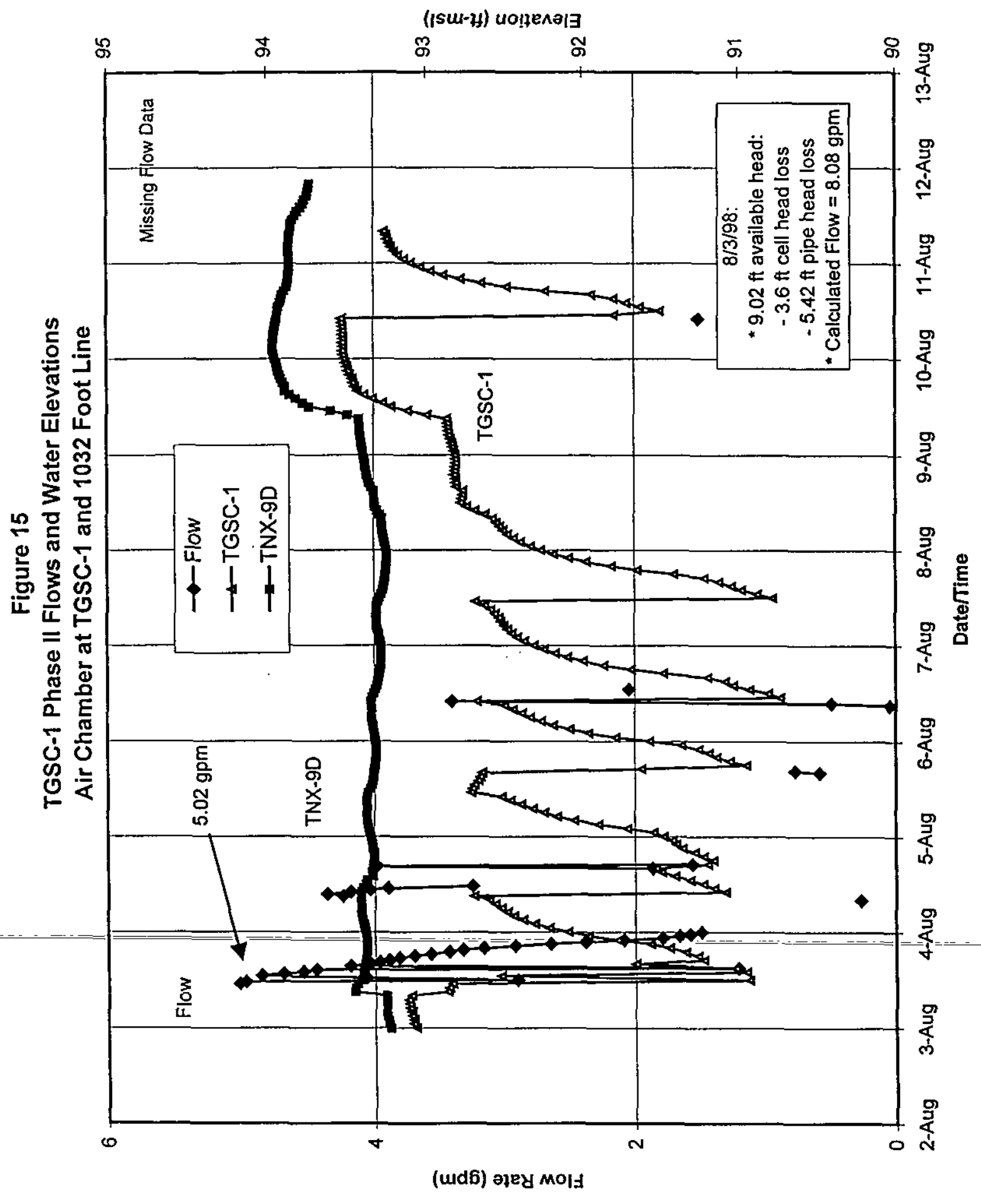

Page 70 of 92 


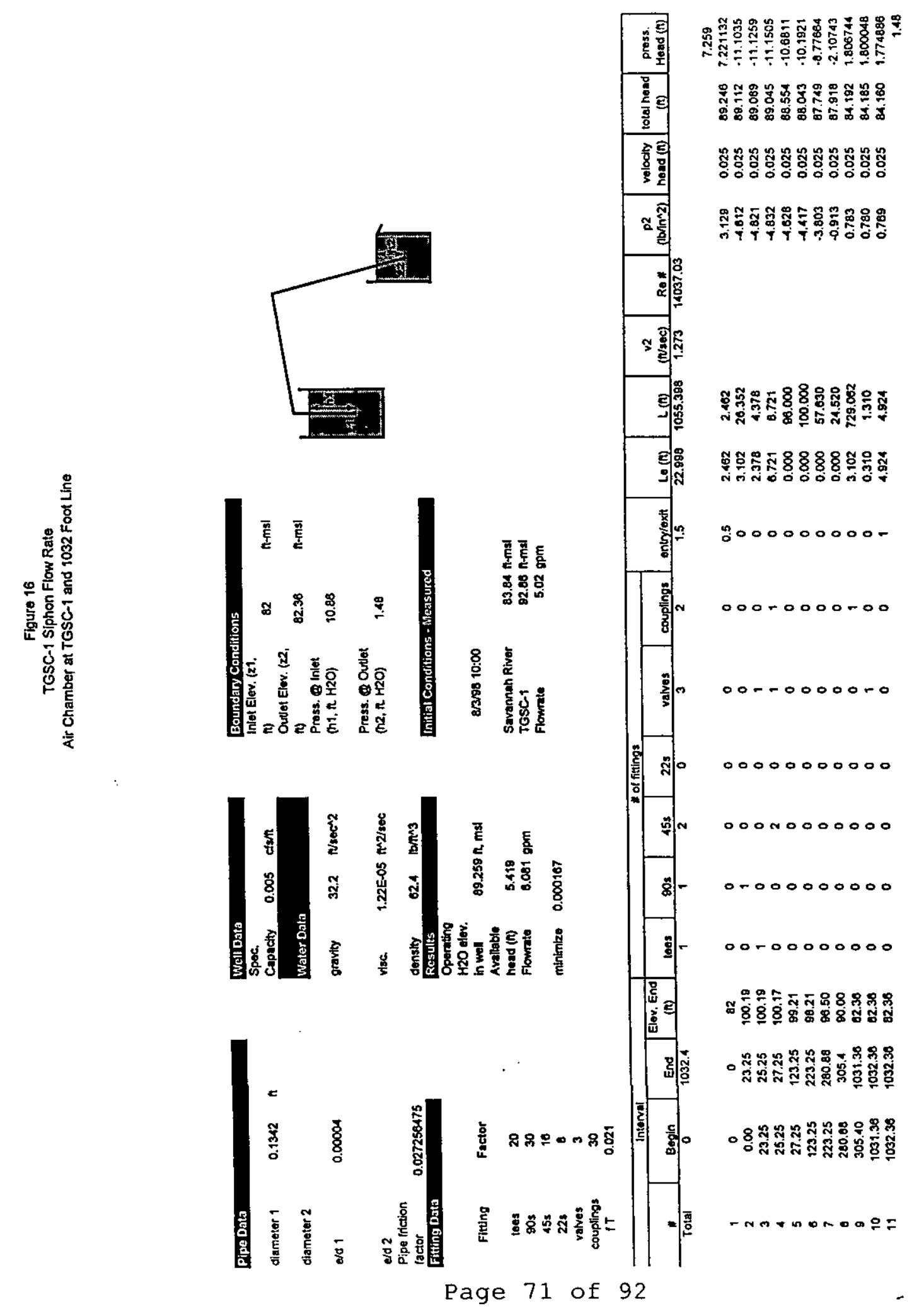




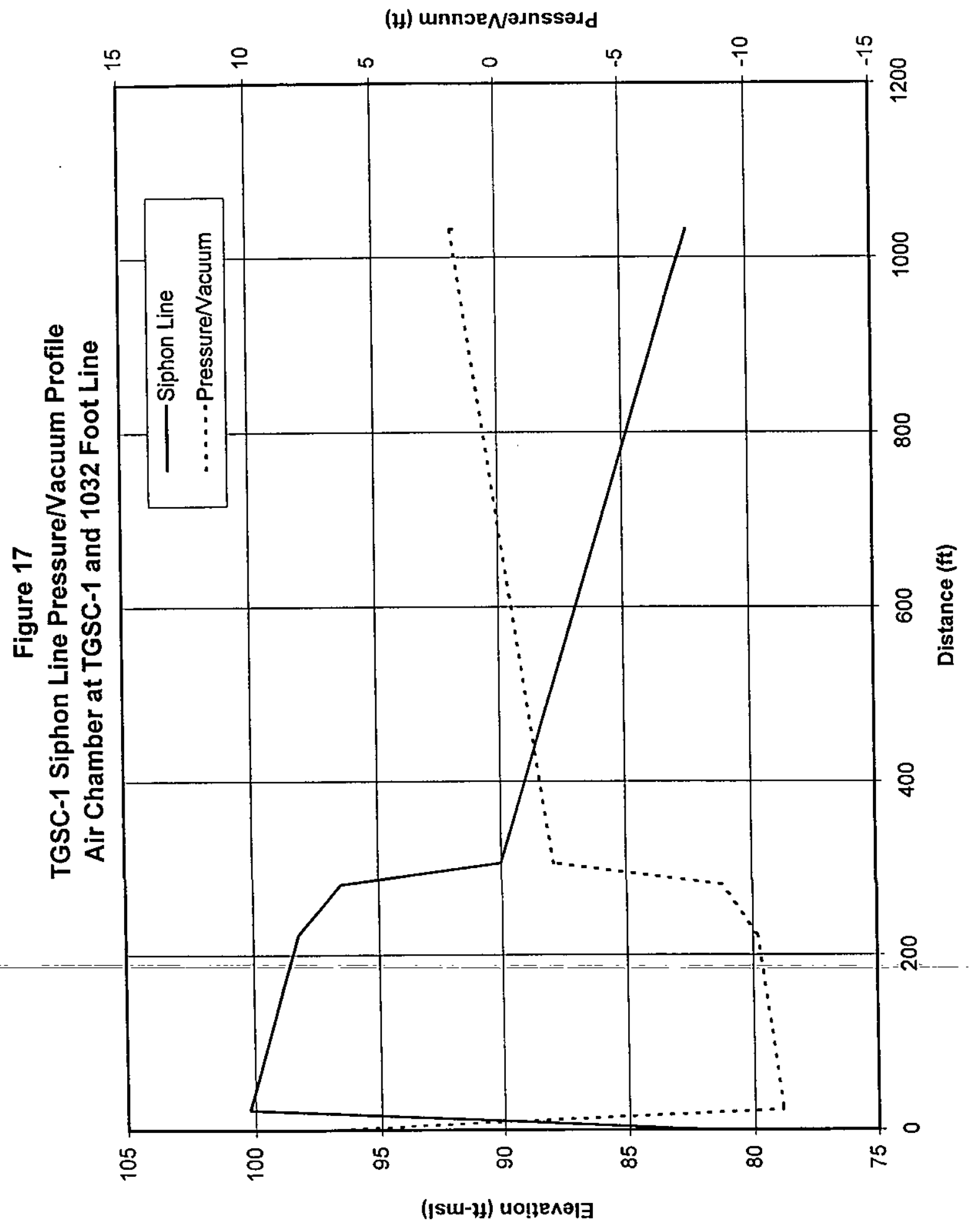

Page 72 of 92 


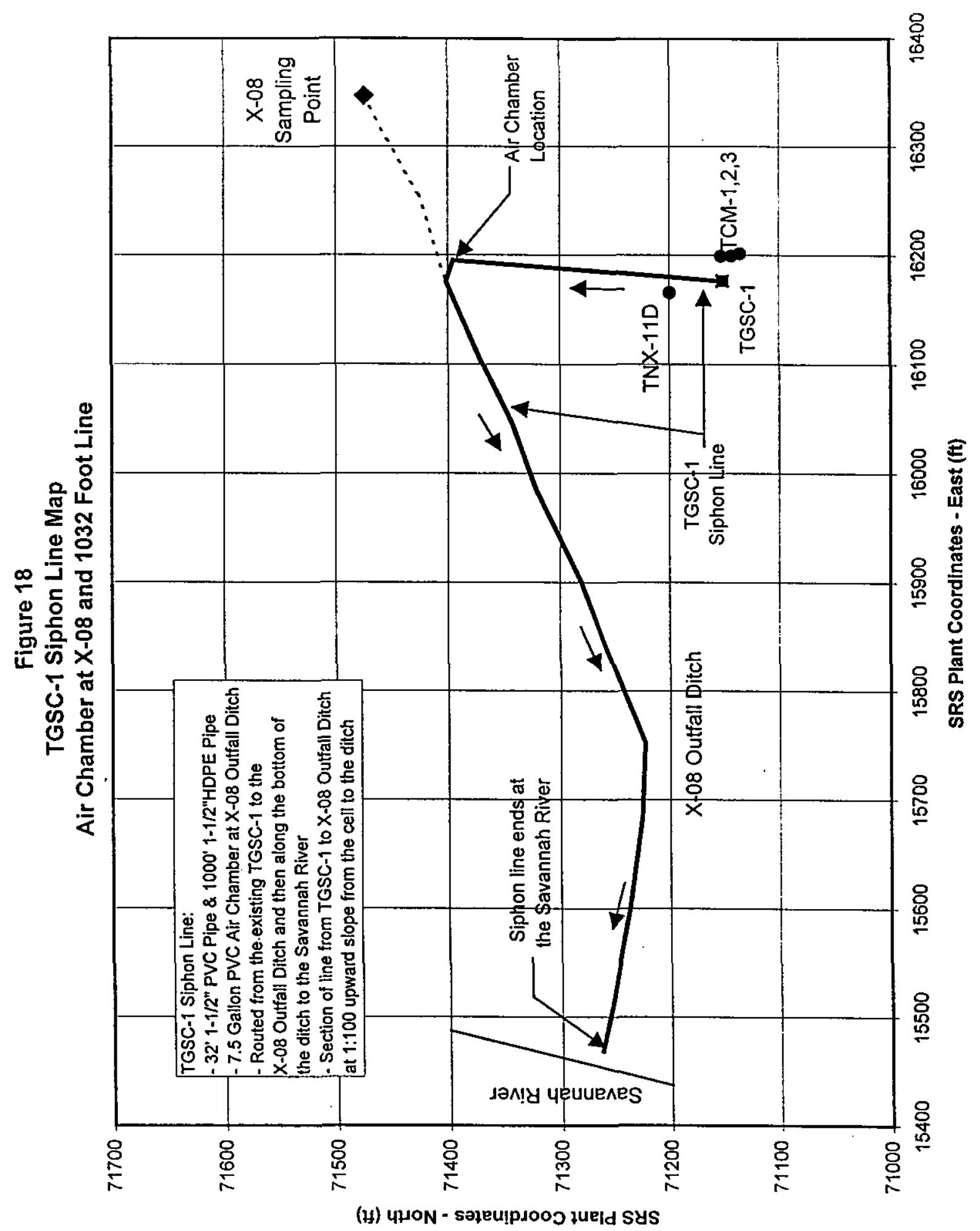

Page 73 of 92 


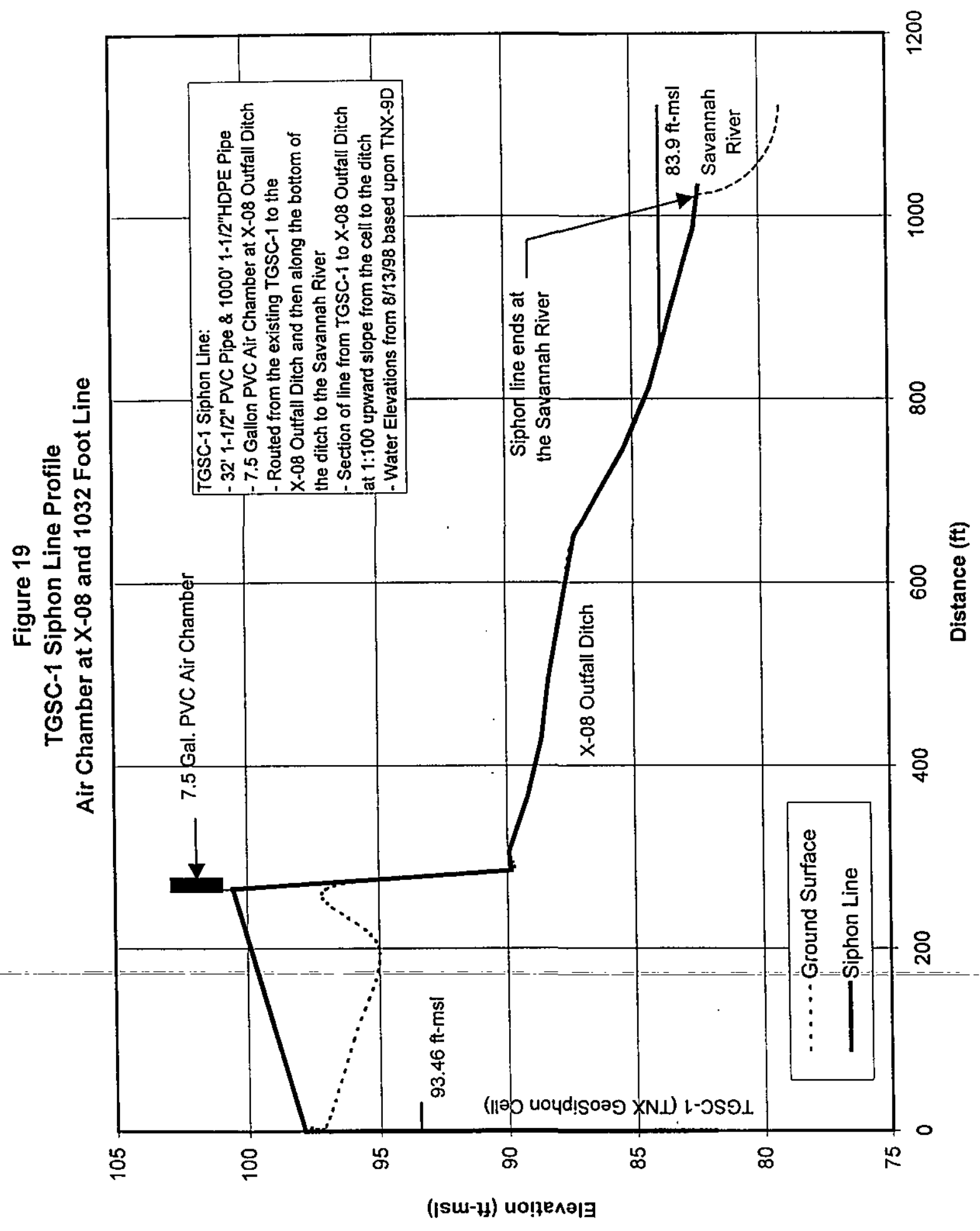

Page 74 of 92 


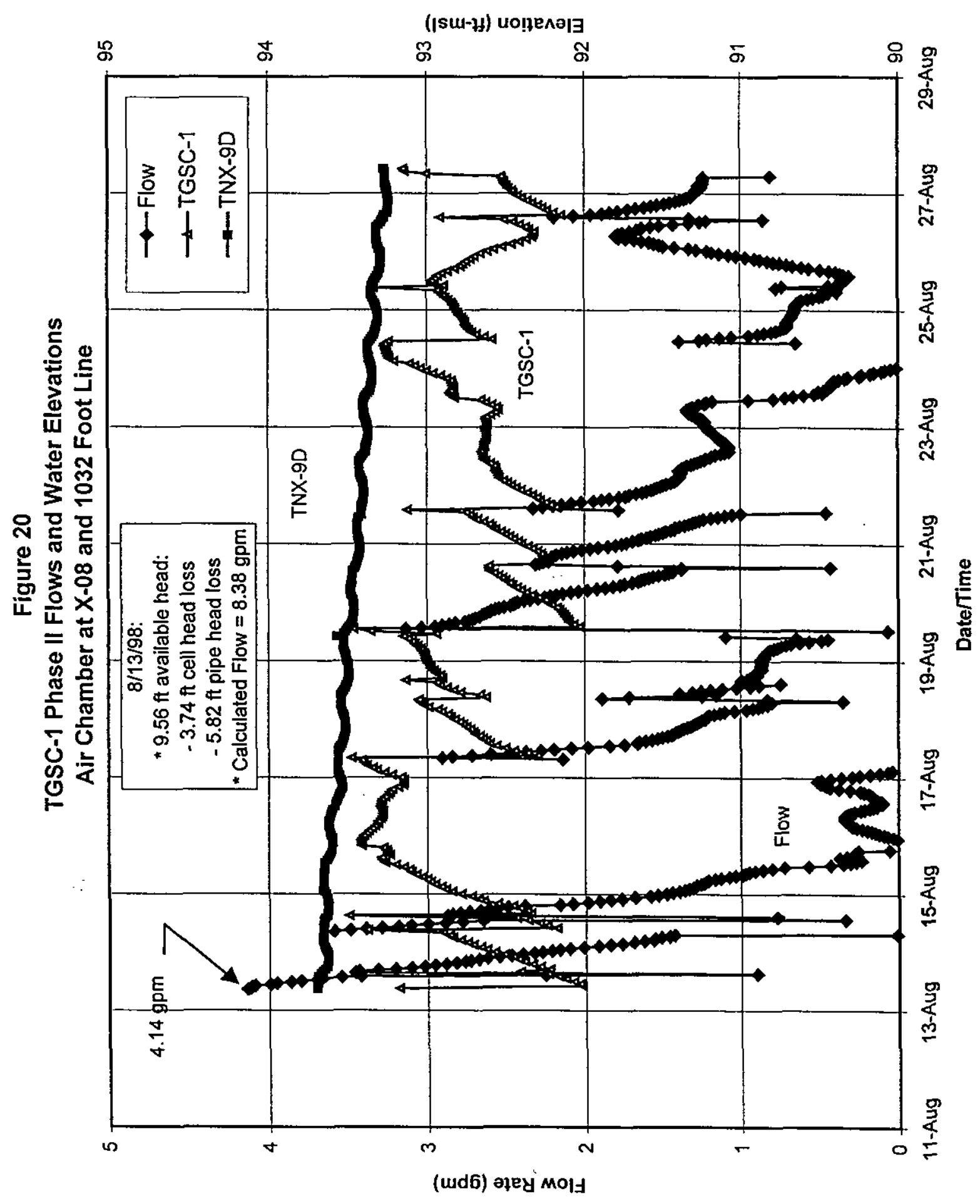

Page 75 of 92 


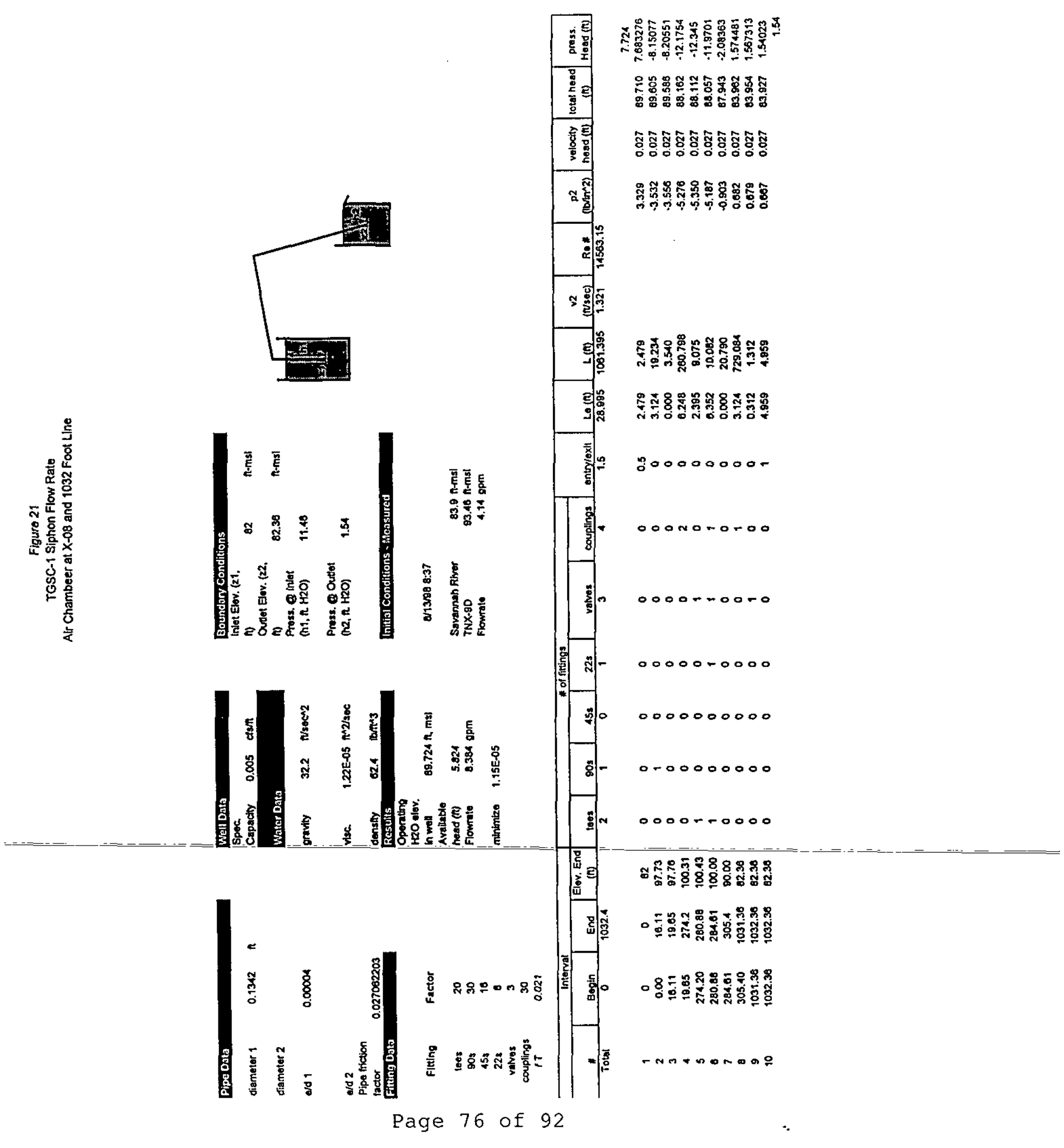




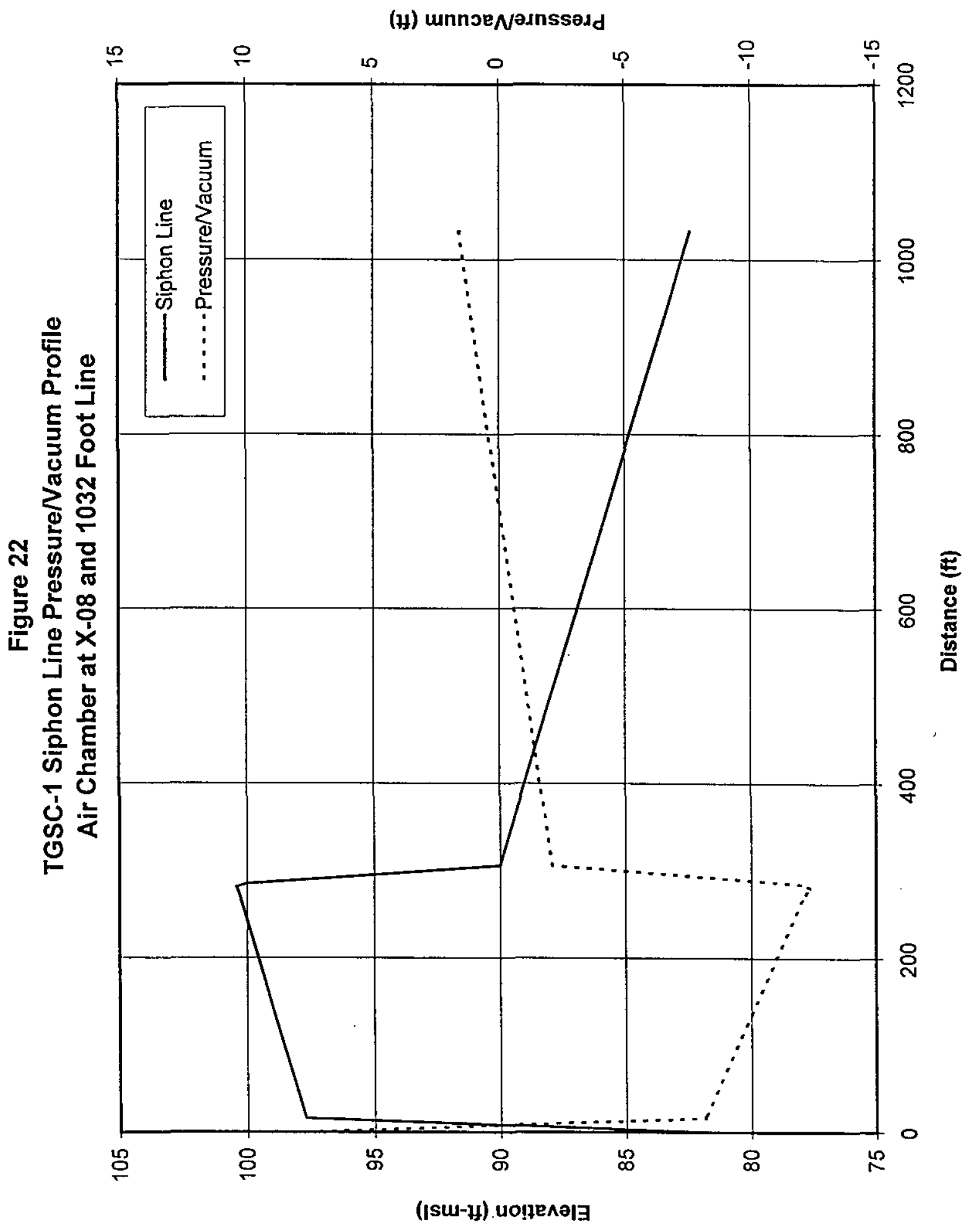

Page 77 of 92 


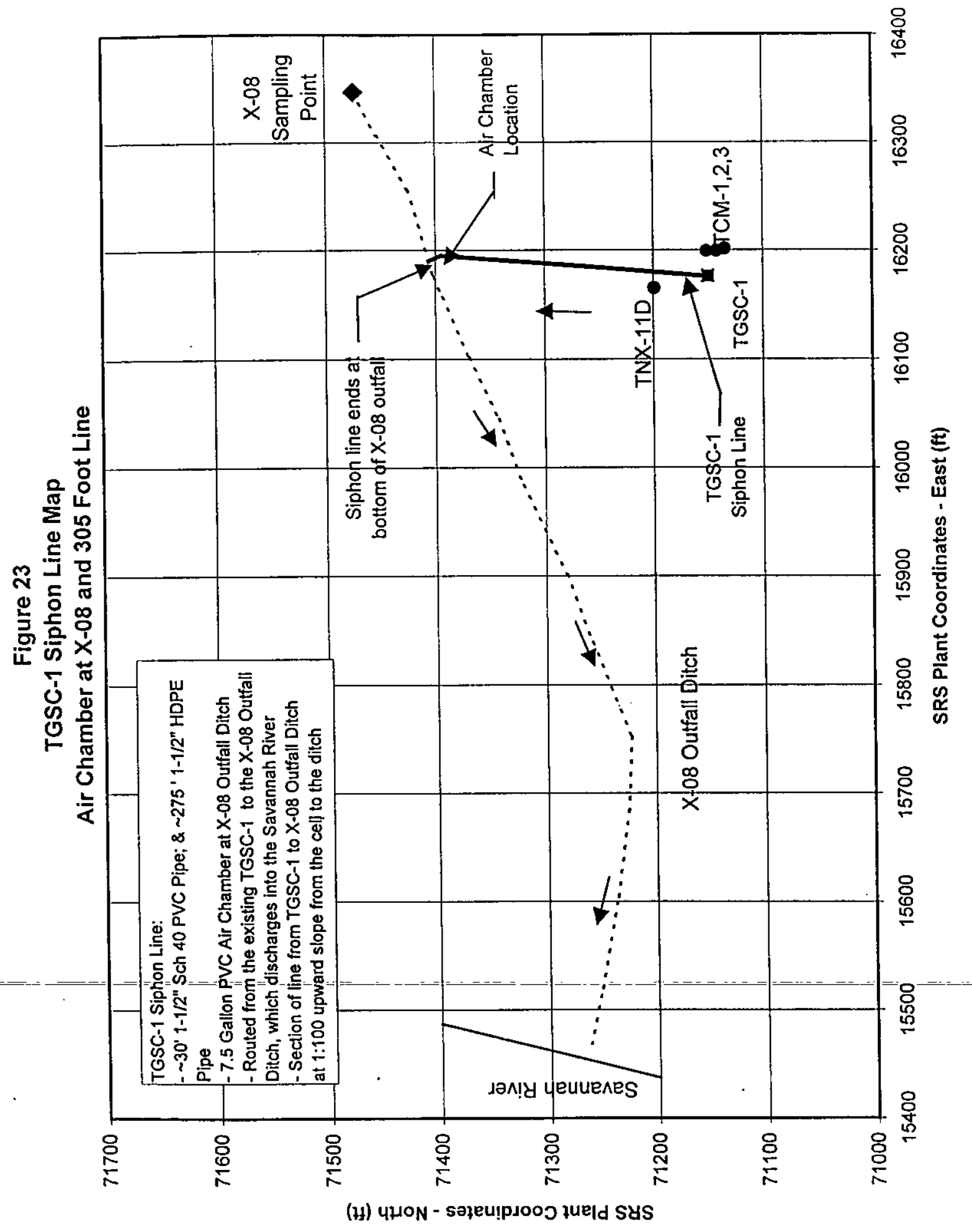

Page 78 of 92 


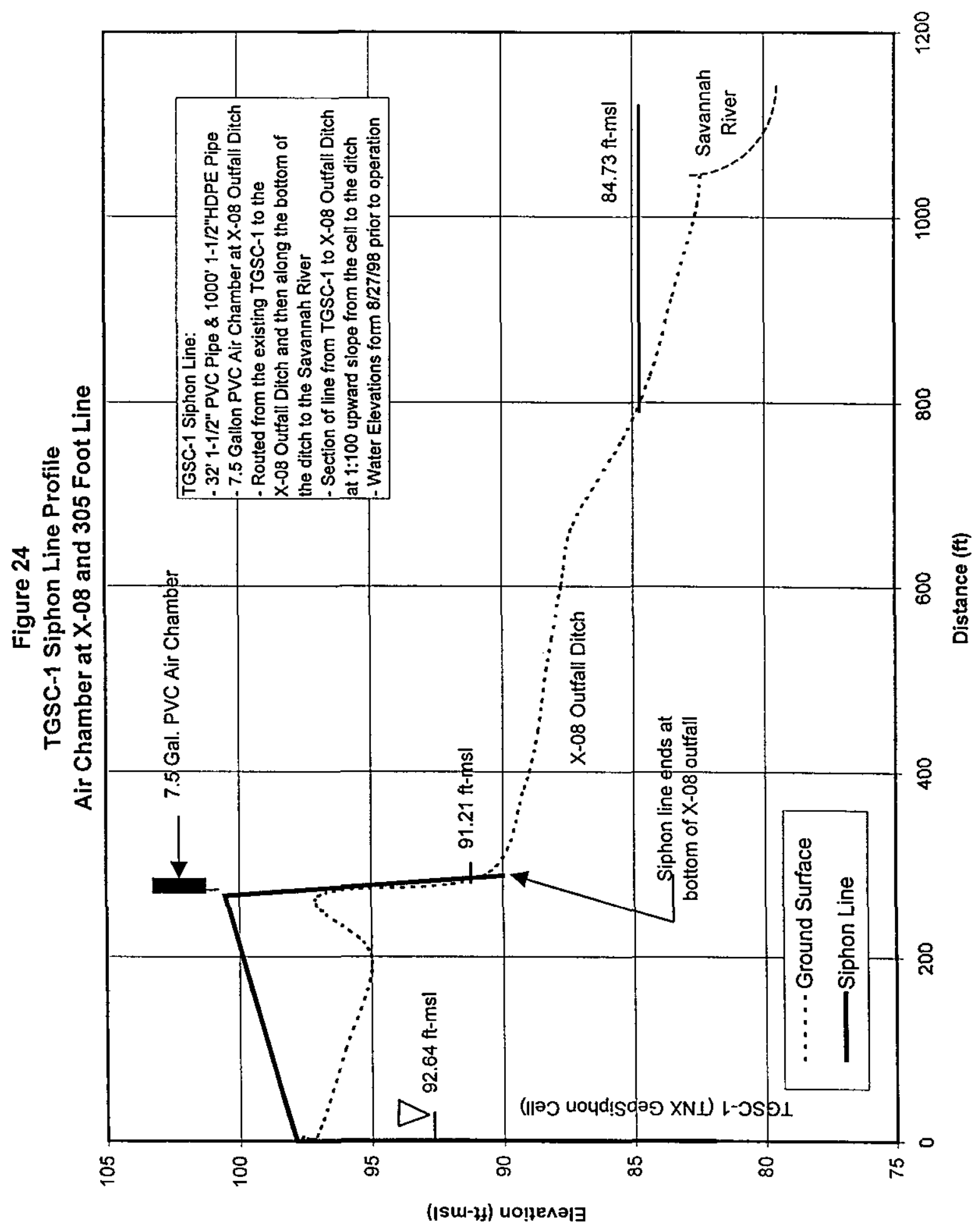

Page 79 of 92 


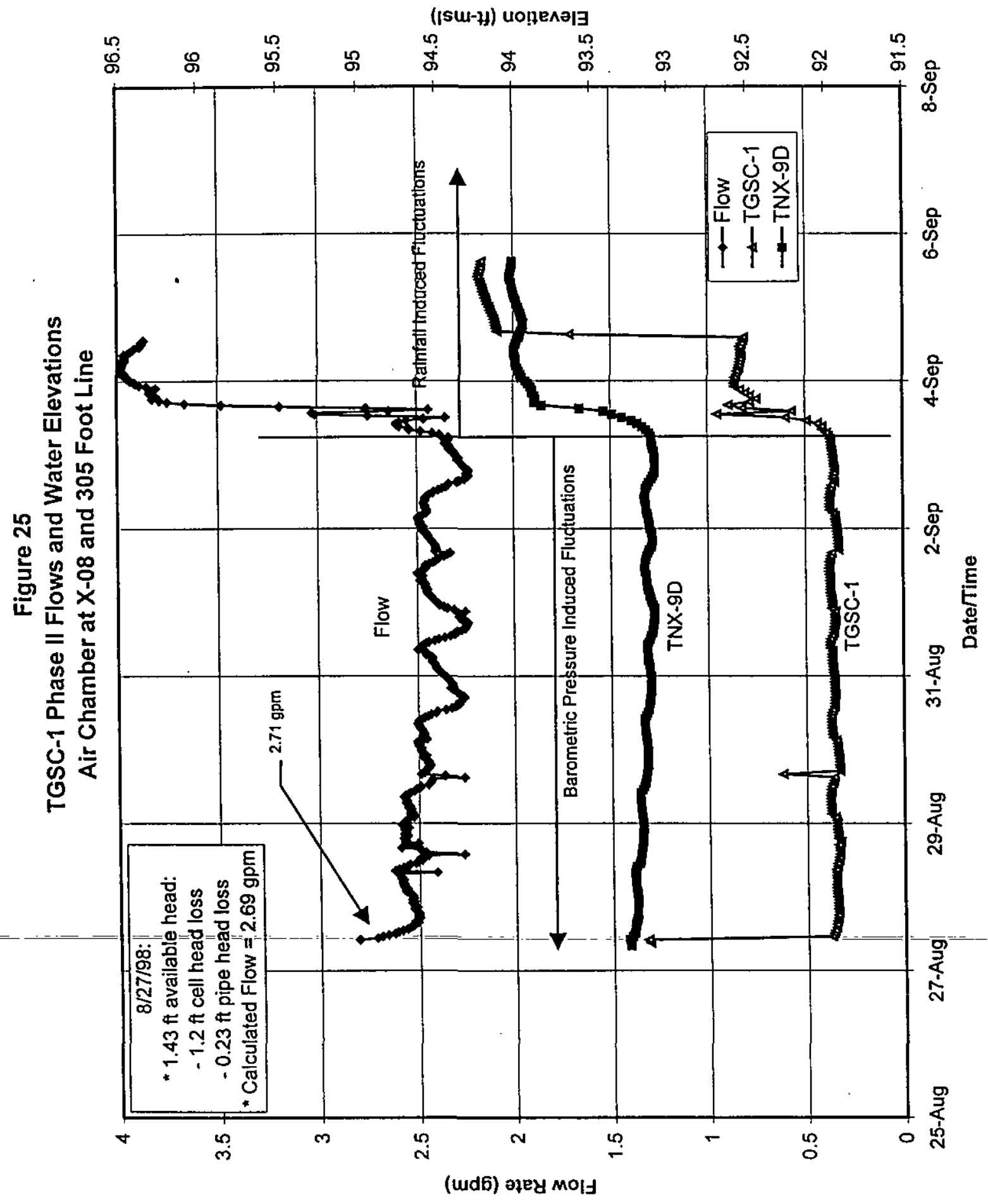

Page 80 of 92 


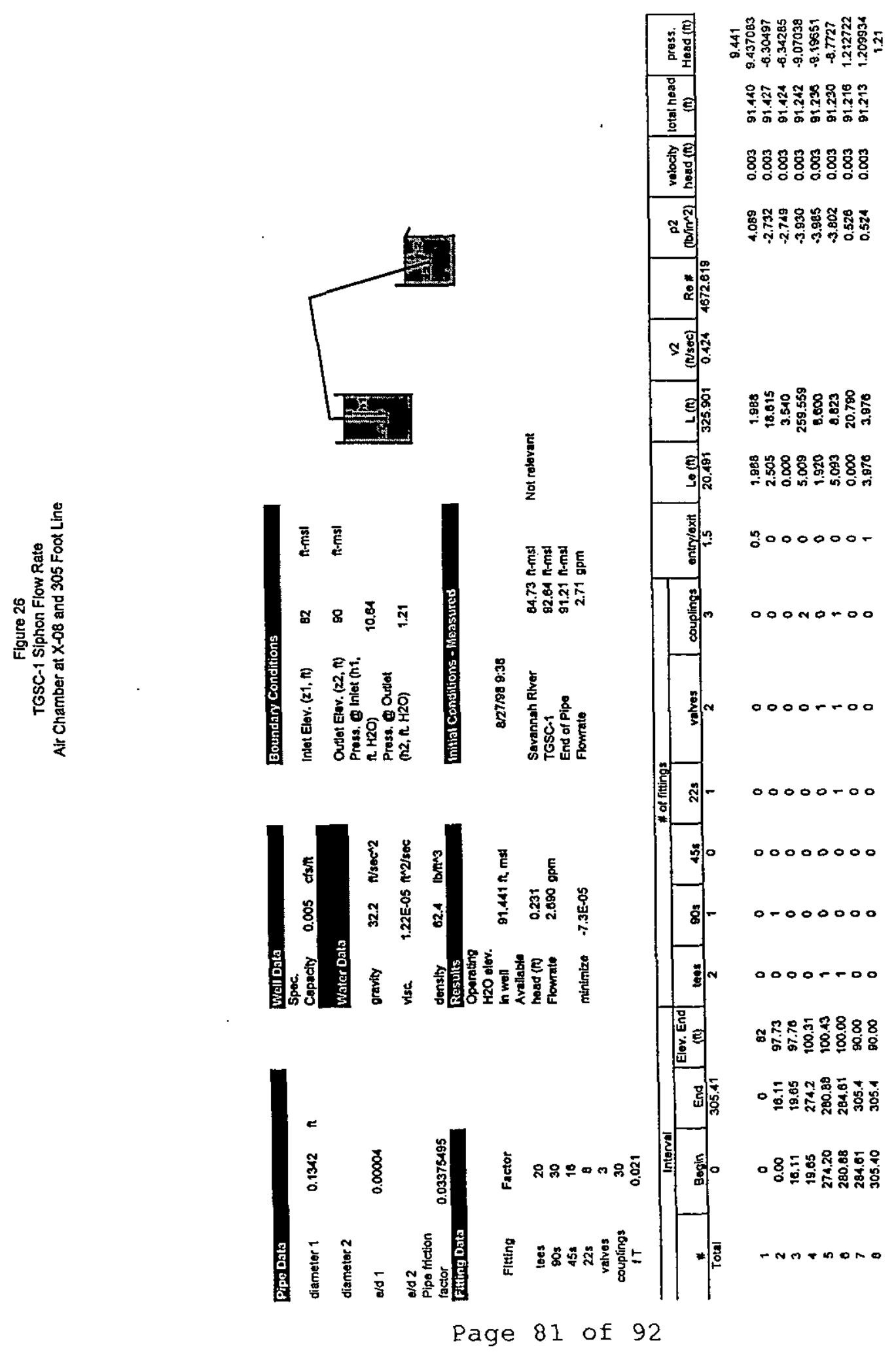




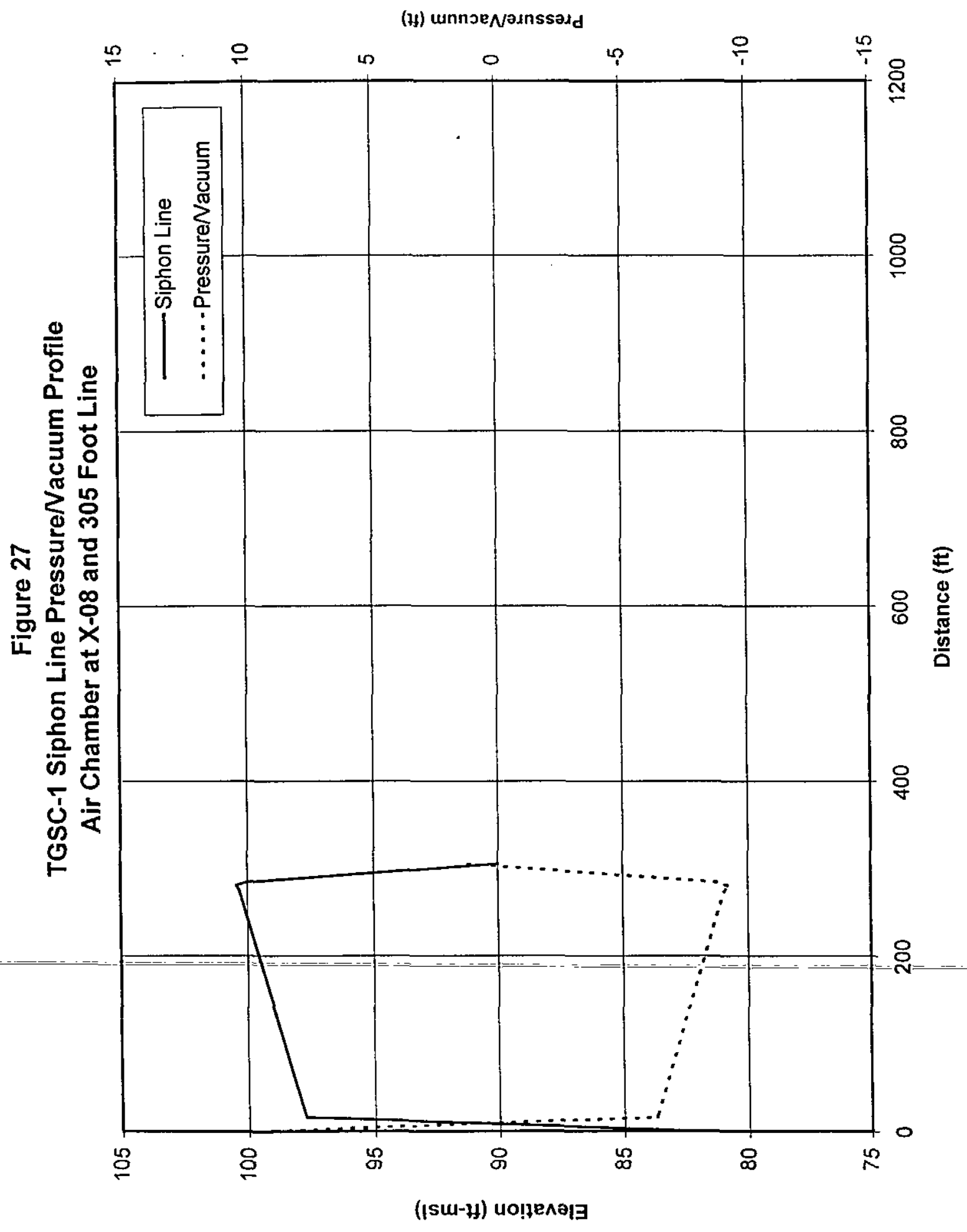

Page 82 of 92 


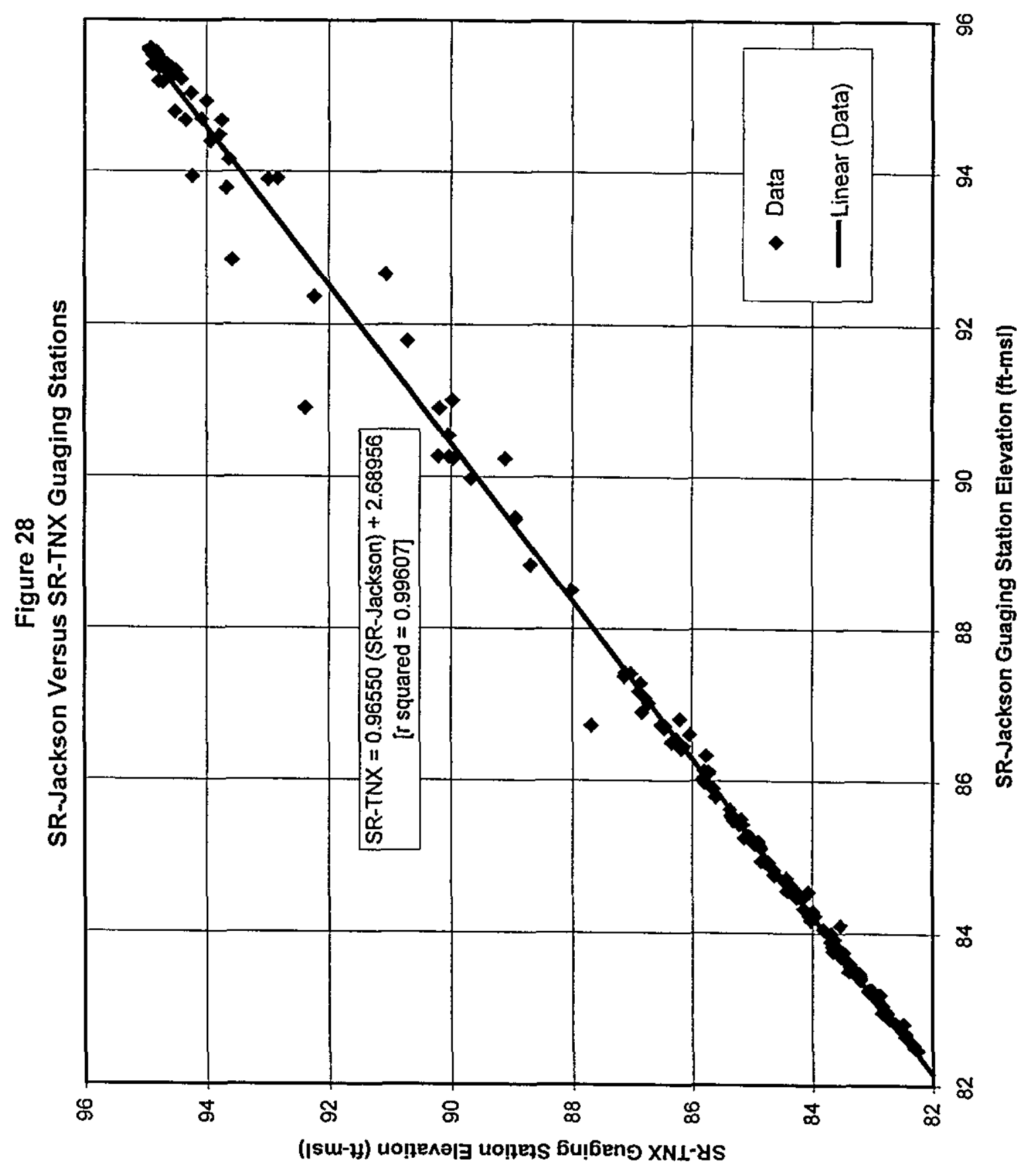

Page 83 of 92 


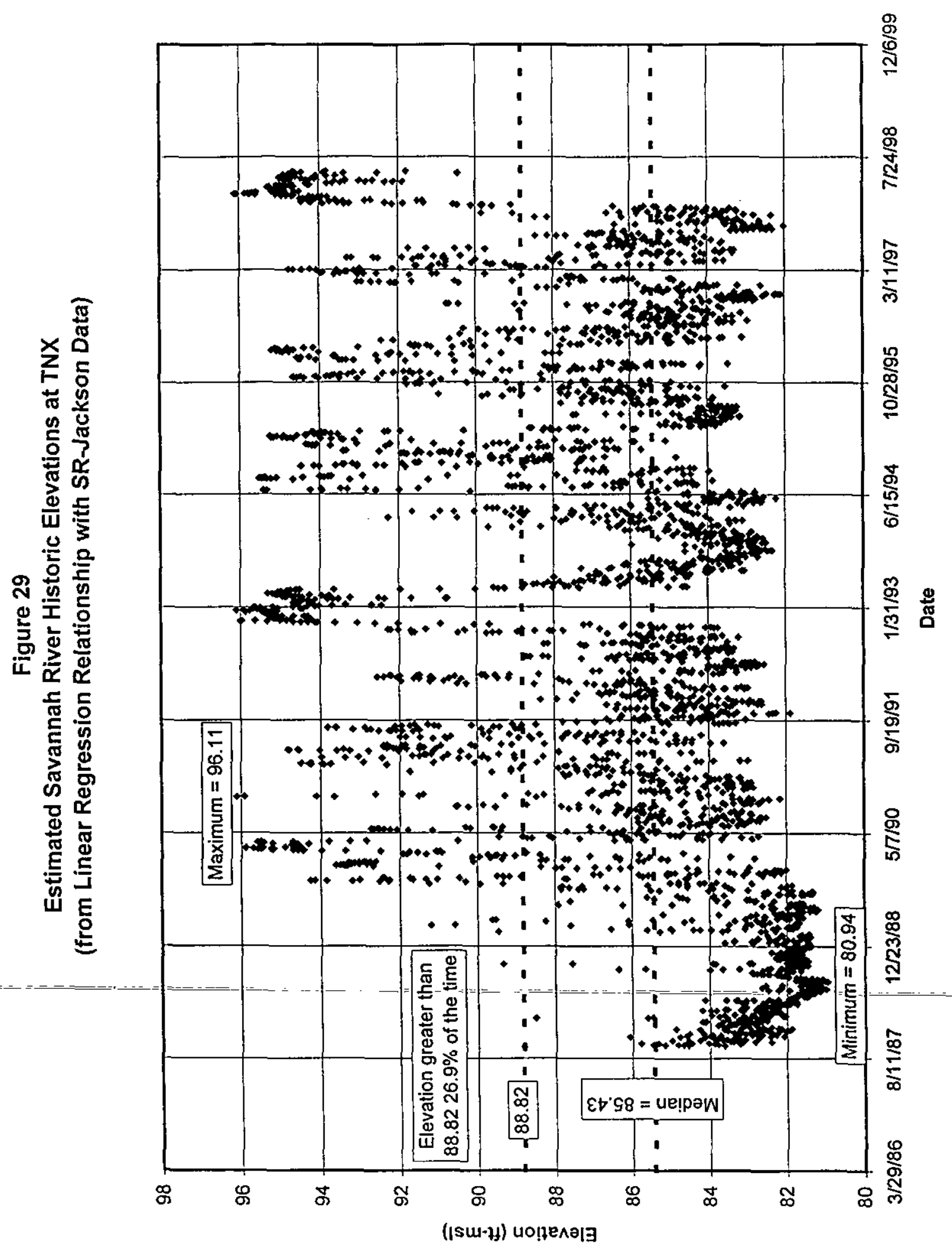

Page 84 of 92 


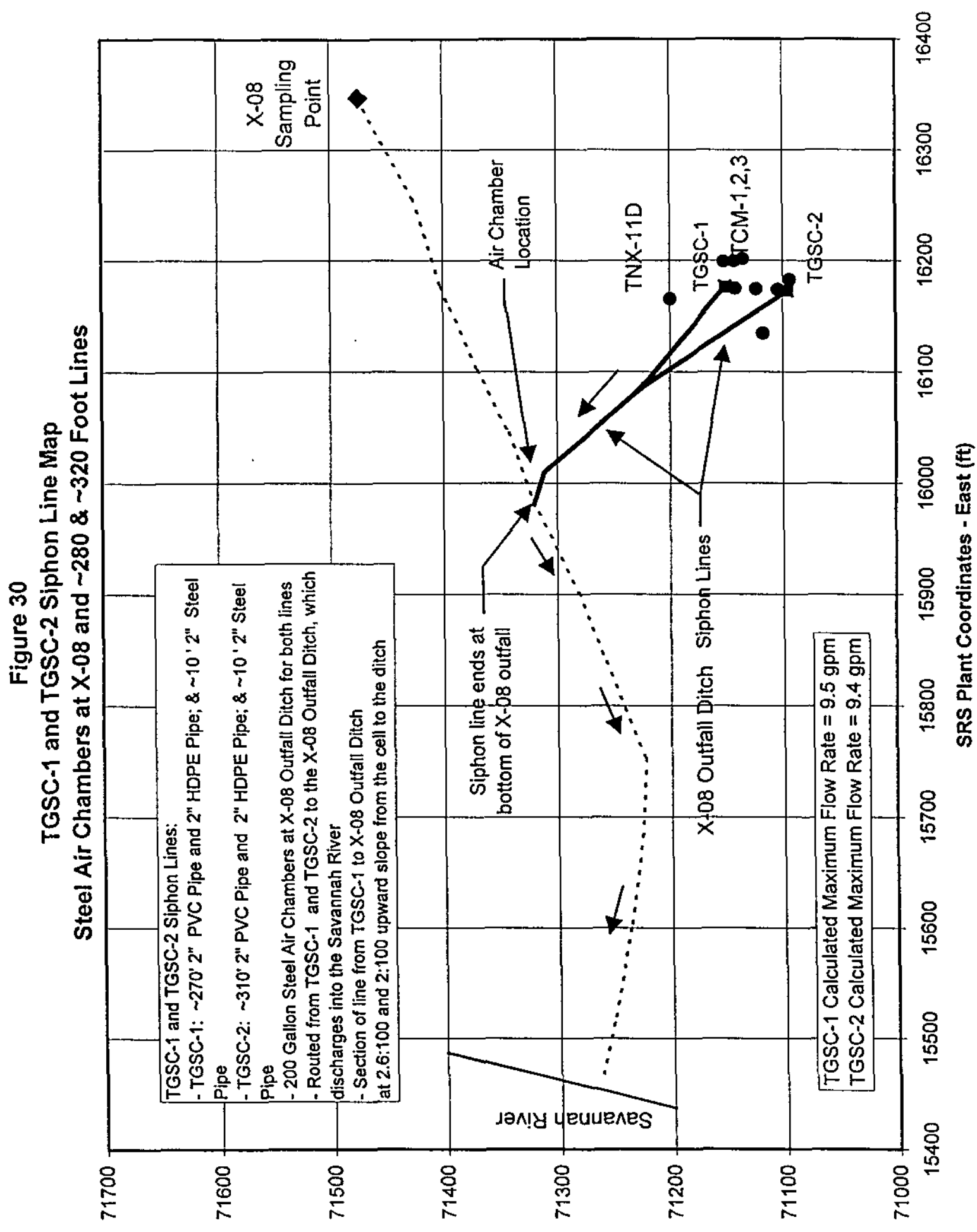

(H) 4นON - sә7еu!p.oOJ jueld SYS

Page 85 of 92 


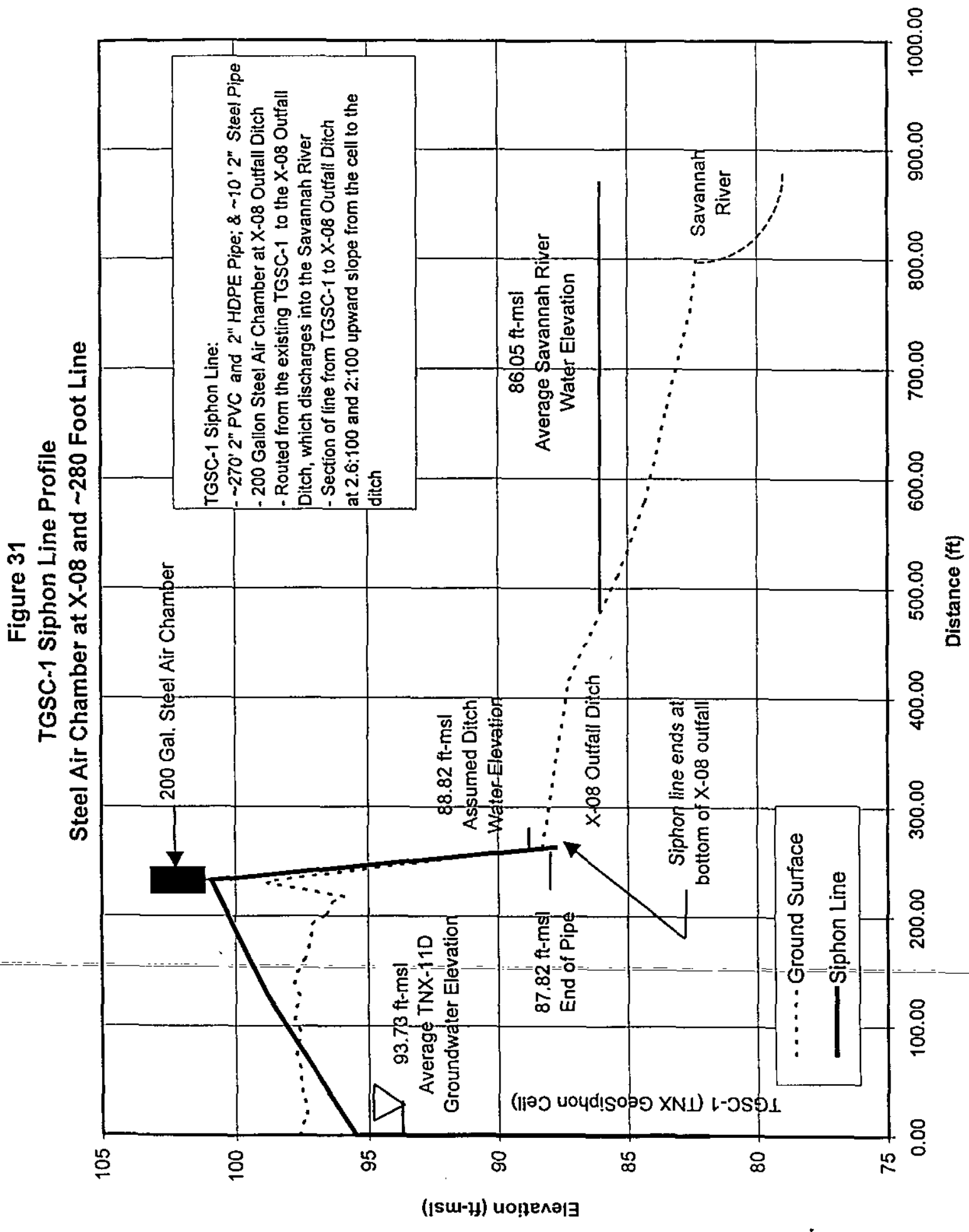

Page 86 of 92 


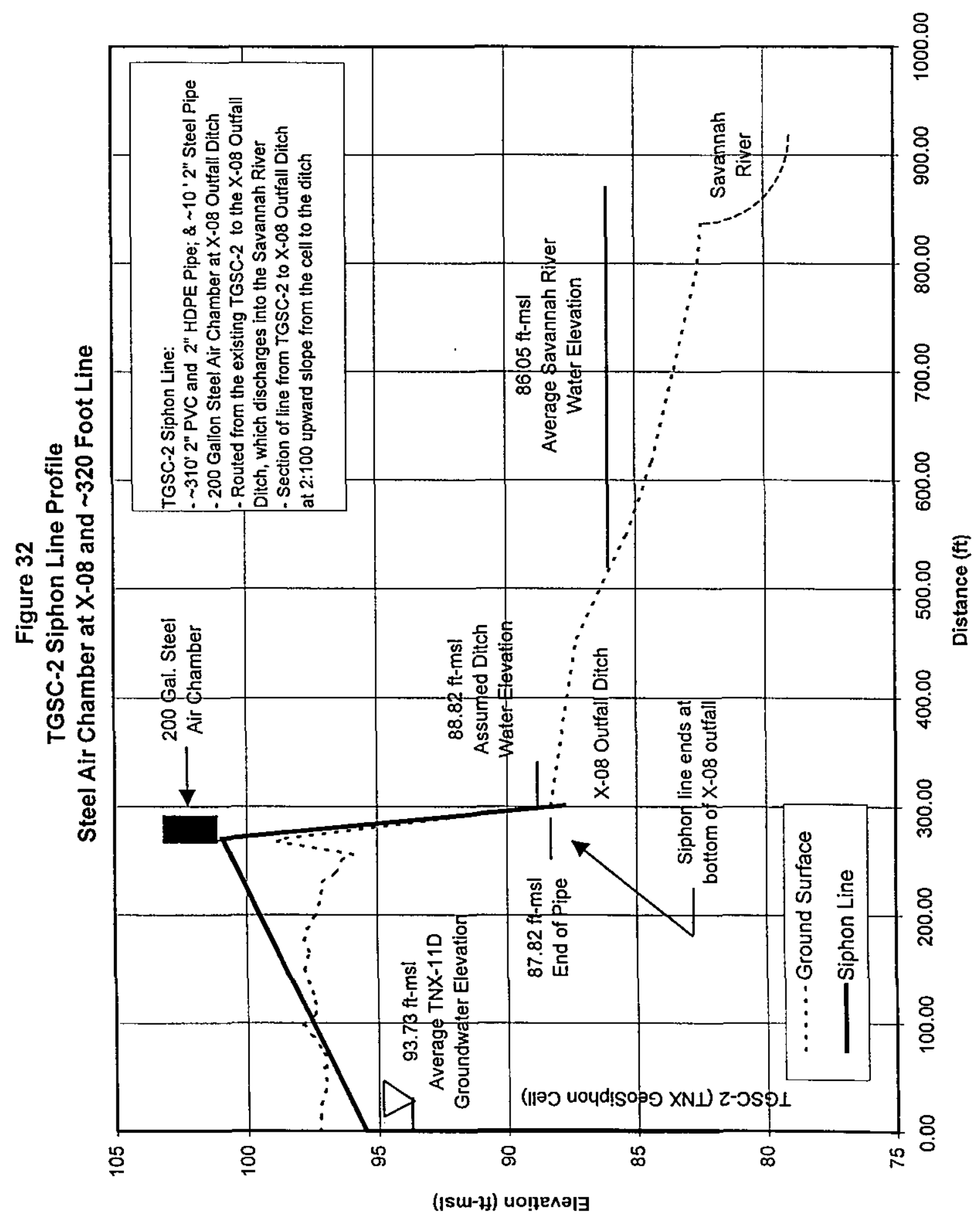

Page 87 of 92 


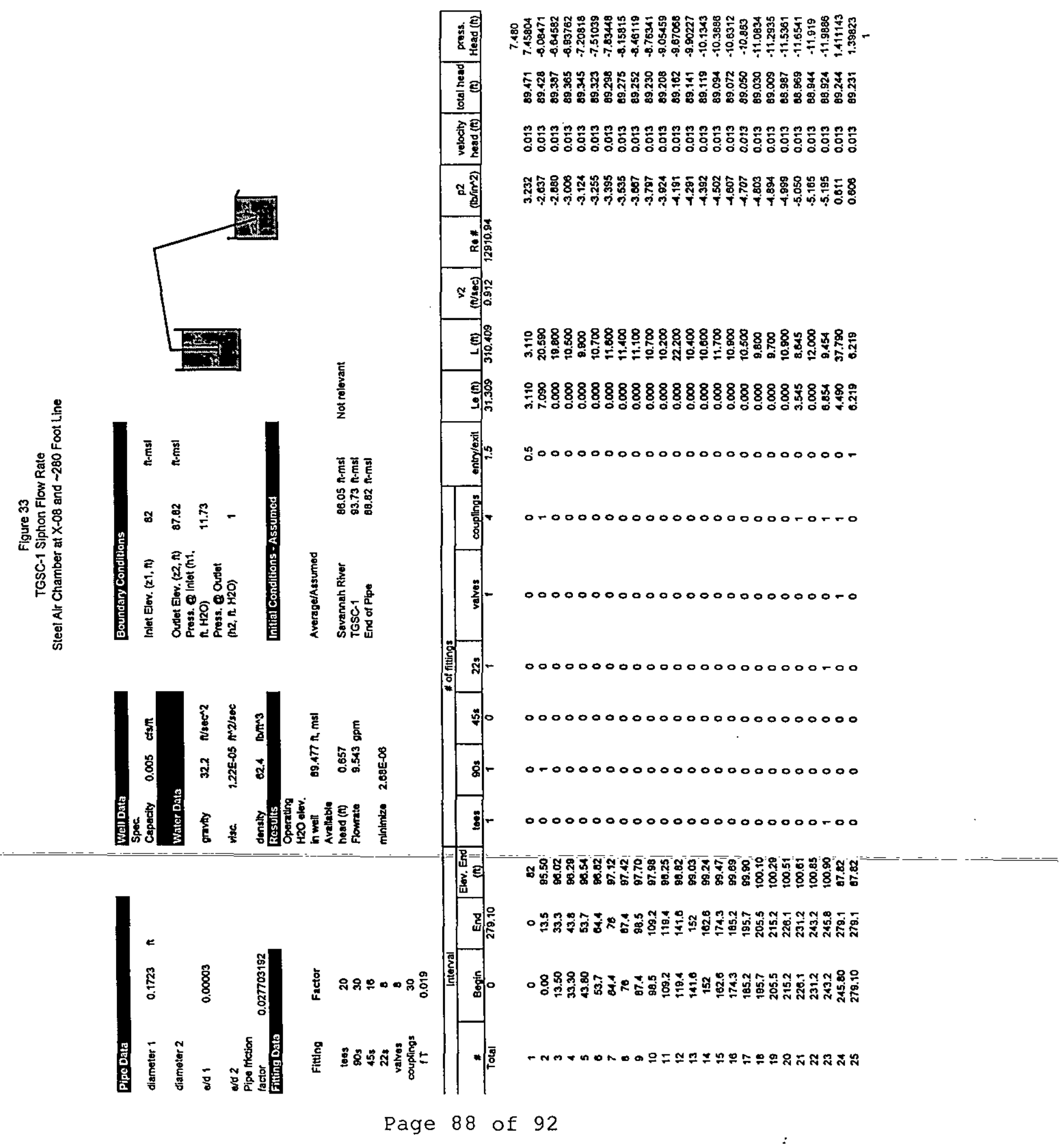



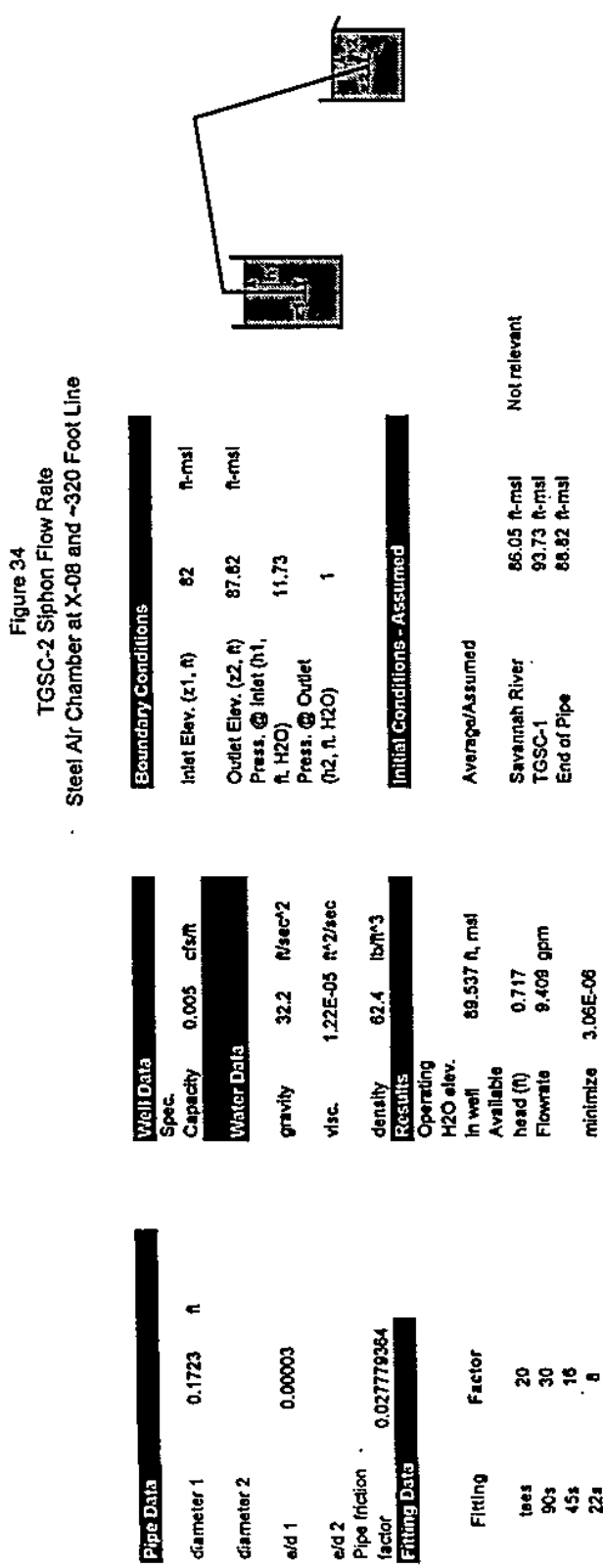

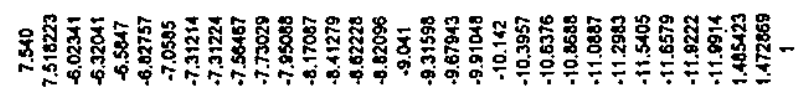

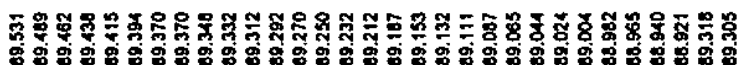

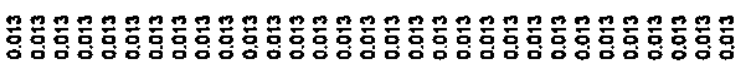

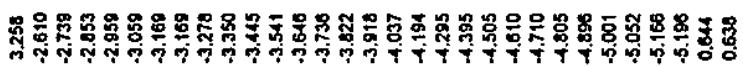

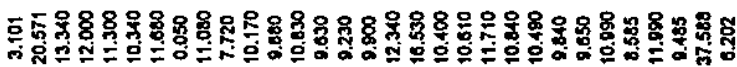

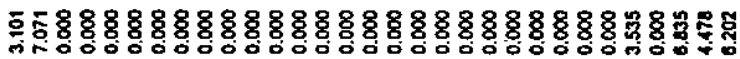

:0000000000000000000000000000000

$0-000000000000000000000000-0-00$

0000000000000000000000000000000 0000000000000000000000000000000 0000000000000000000000000000000 $0-00000000000000000000000000000$ $0000000000000000000000000000-00$

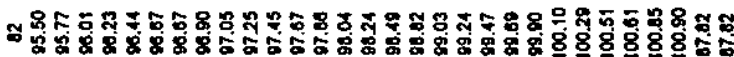

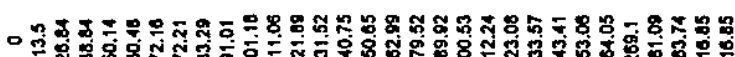

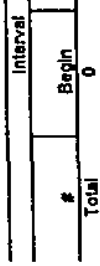

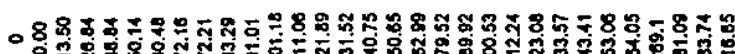

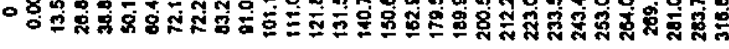

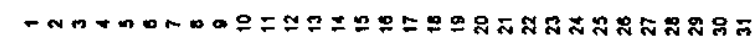




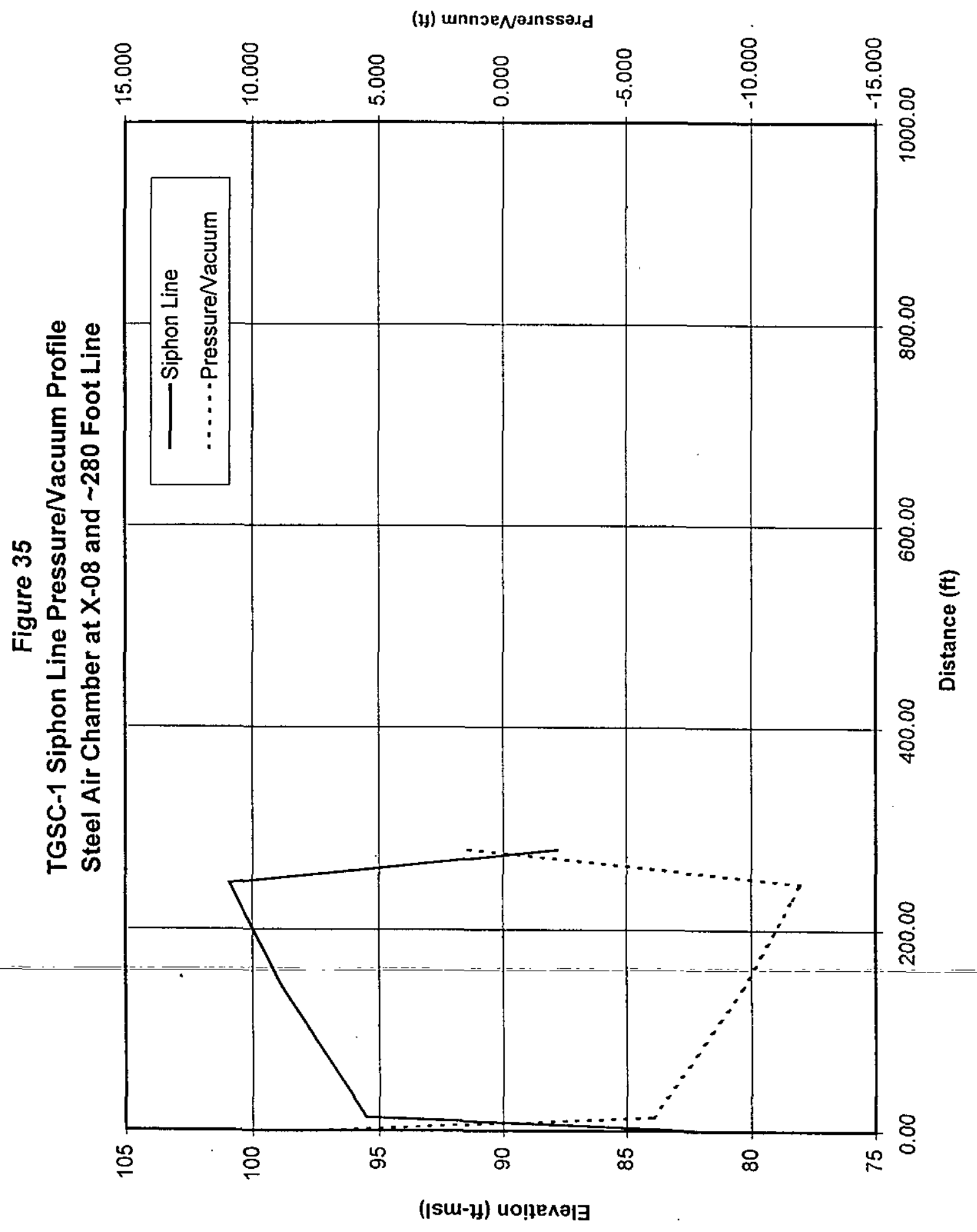

Page 90 of 92 


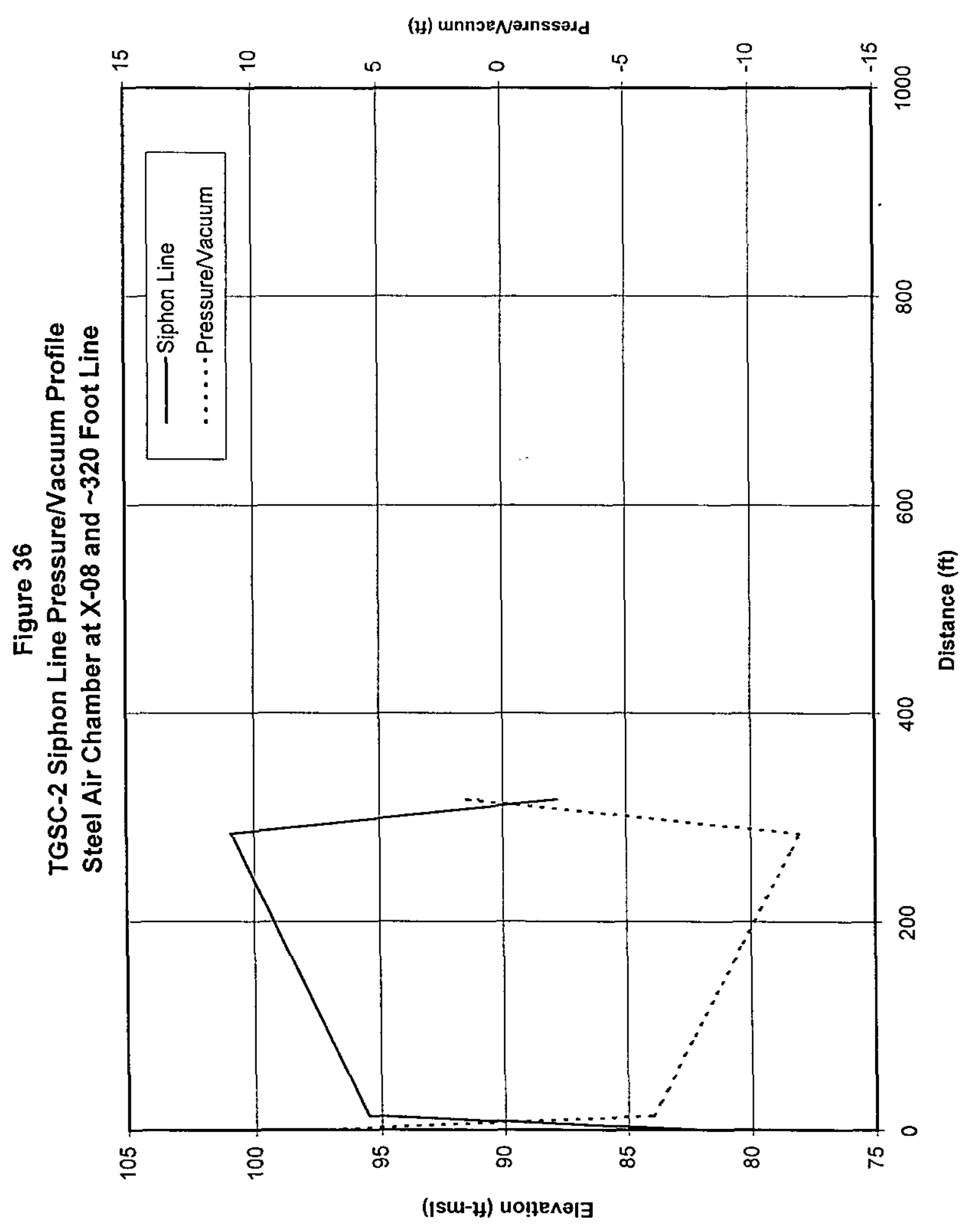

Page 91 of 92 
Left Blank Intentionally 


\begin{abstract}
APPENDICES
Appendix A, Phase II Hand Recorded Hydraulic Data Appendix B, SR-Jackson and SR-TNX Gauging Station Linear Regression Relationship Appendix C, SR-TNX Estimated Historic Daily Mean Elevation Appendix D, TNX GeoSiphon Cell Detailed Organic Data Appendix E, TNX GeoSiphon Cell Detailed Field Data Appendix F, TNX GeoSiphon Cell Detailed Inorganic Data Appendix G, TNX GeoSiphon Cell Detailed Gas Analyses
\end{abstract}


Appendix A

Phase II Hand Recorded Hydraulic Data

Appendix A-1, Siphon Line Configuration \# 1 With One Valve At TGSC-1 Crest Appendix A-2, Siphon Line Configuration \# 1 With Two Valves At TGSC-1 Crest Appendix A-3, Siphon Line Configuration \# 2

Appendix A-4, Siphon Line Configuration \# 3

Appendix A-5, Siphon Line Configuration \# 4 

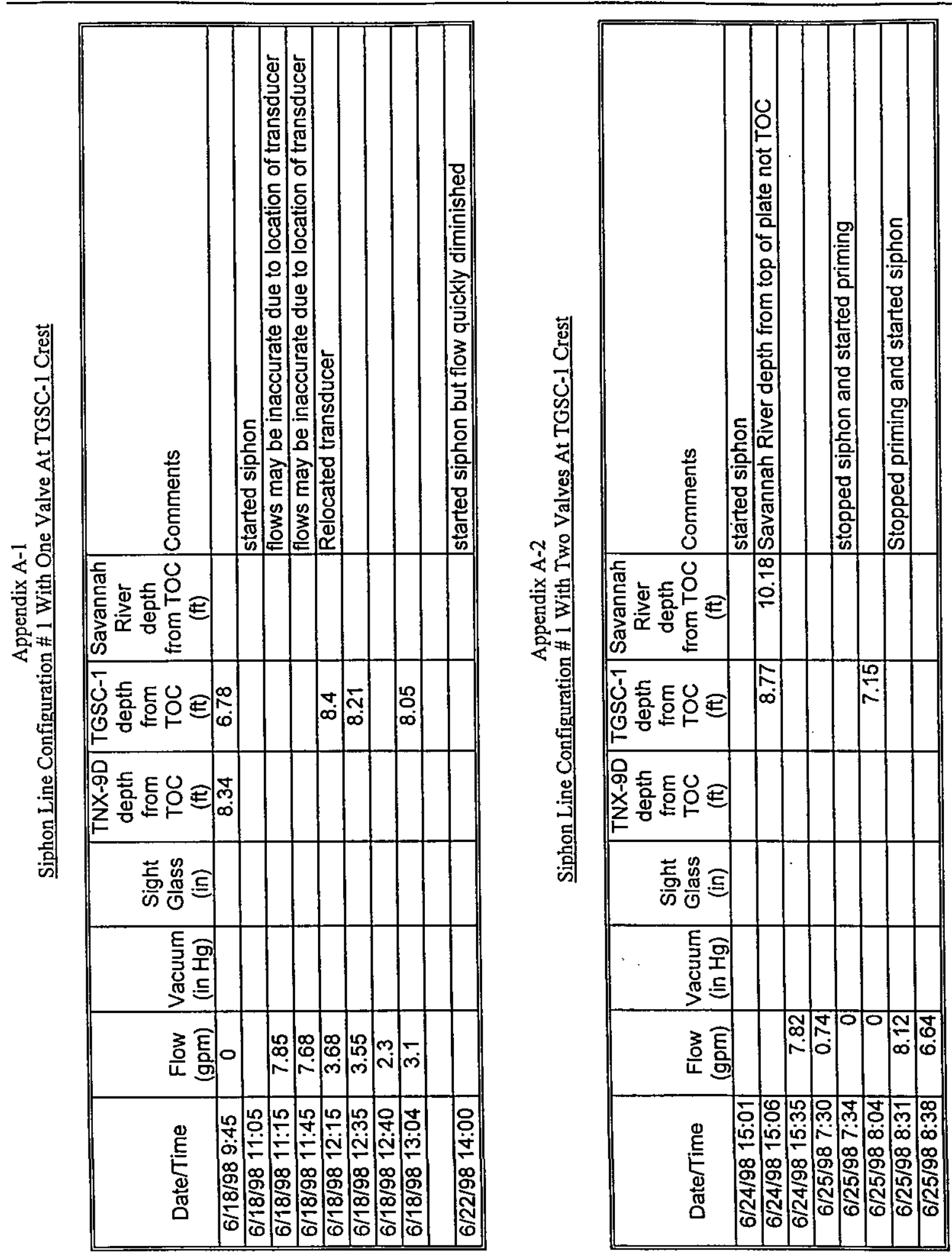


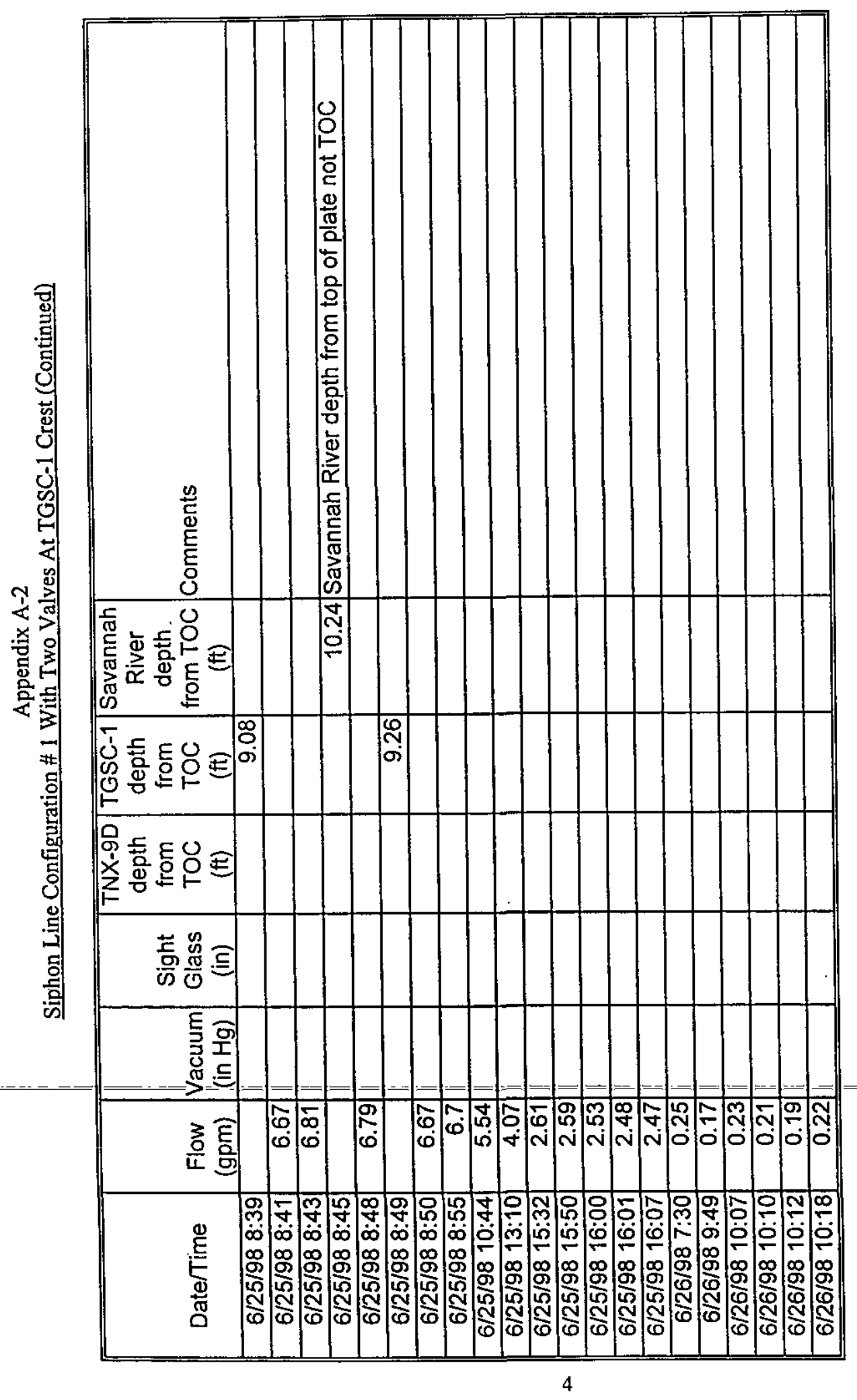




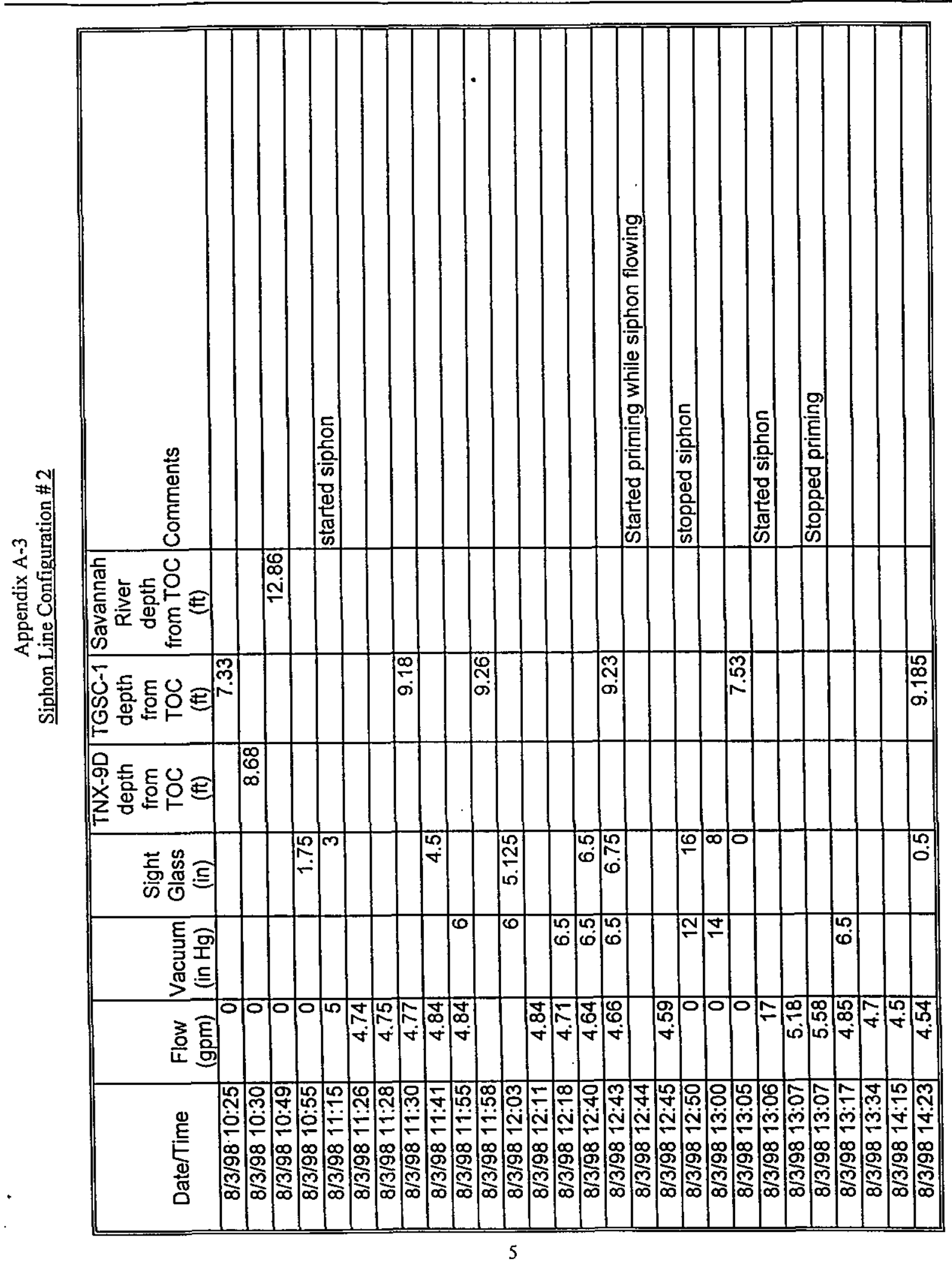




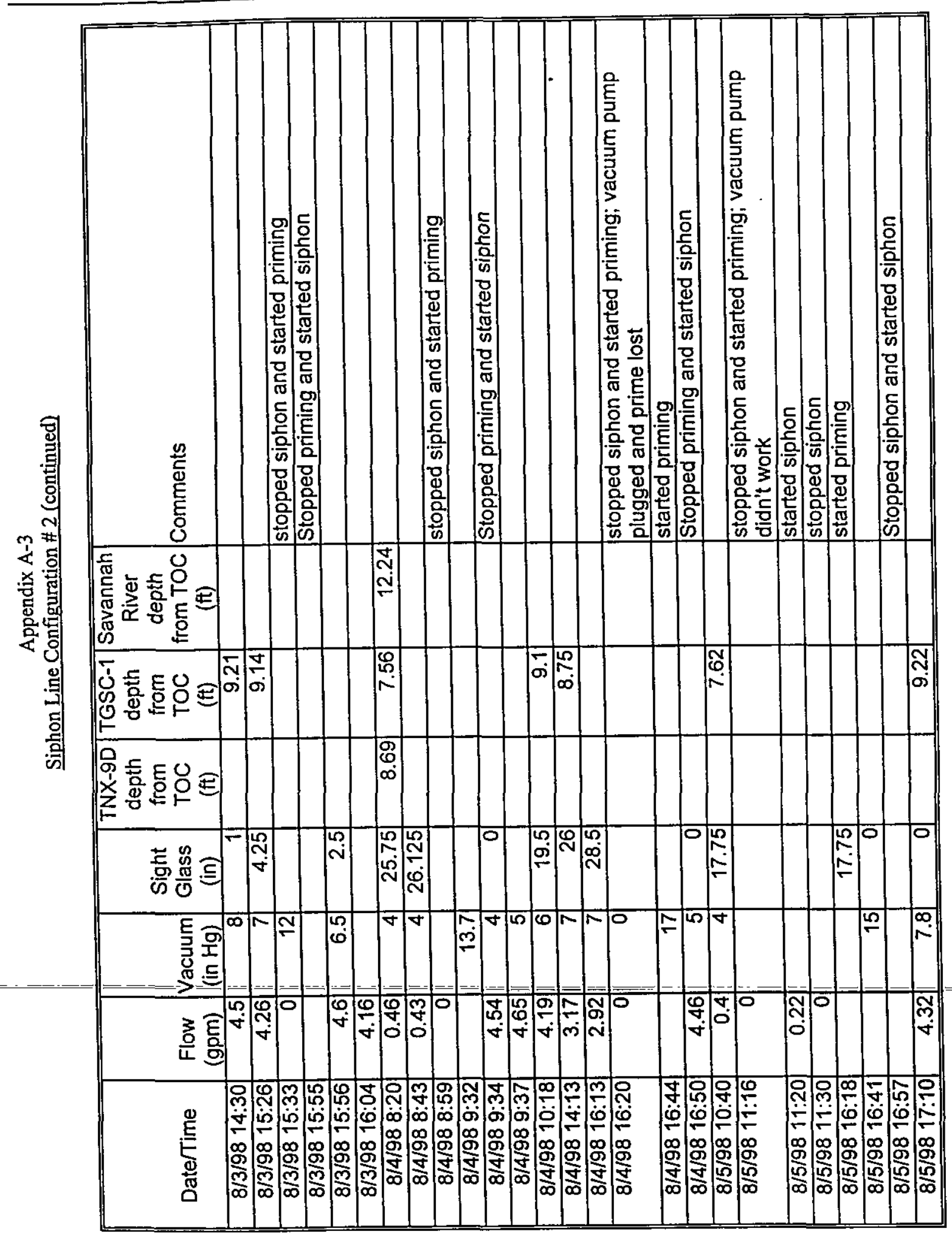




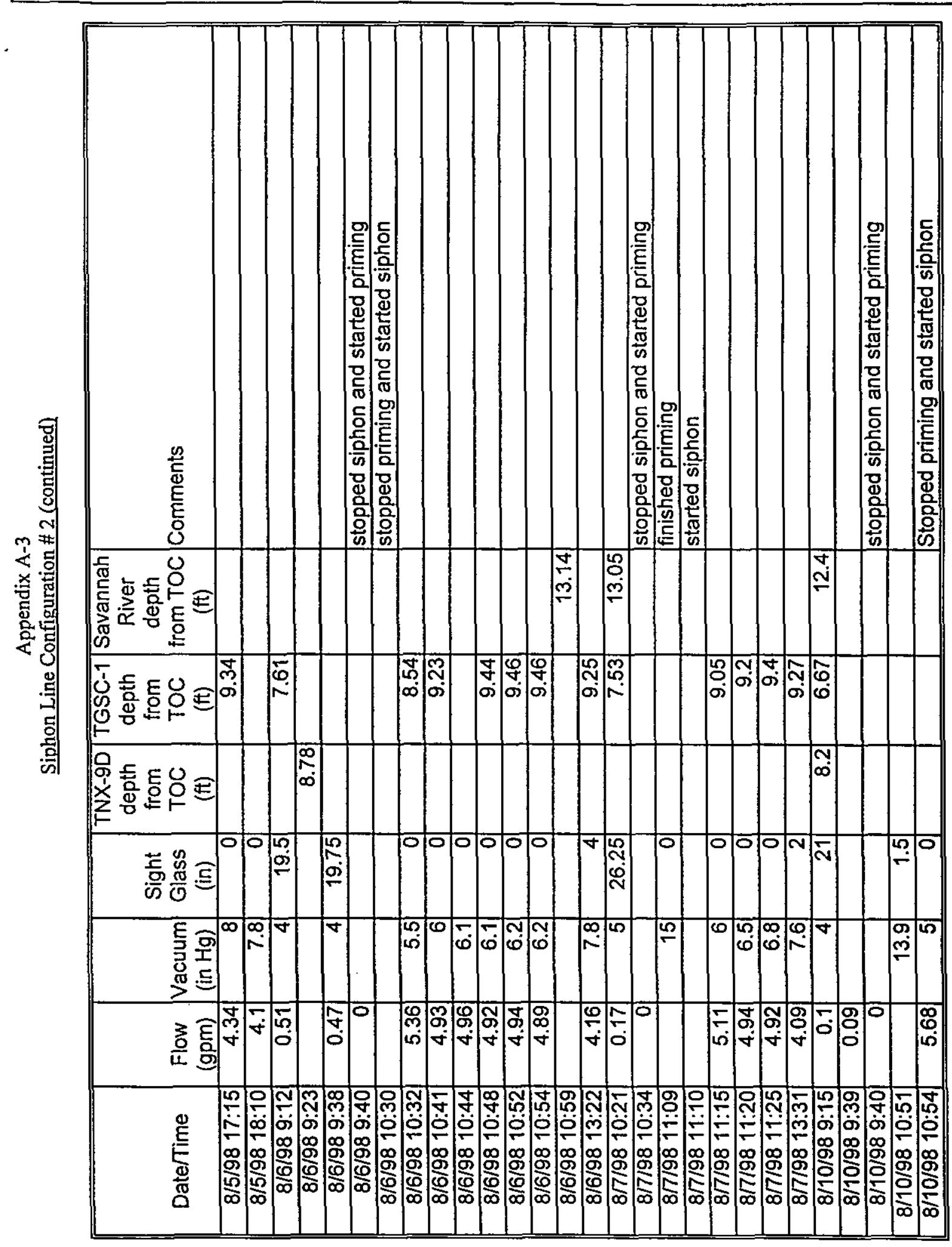



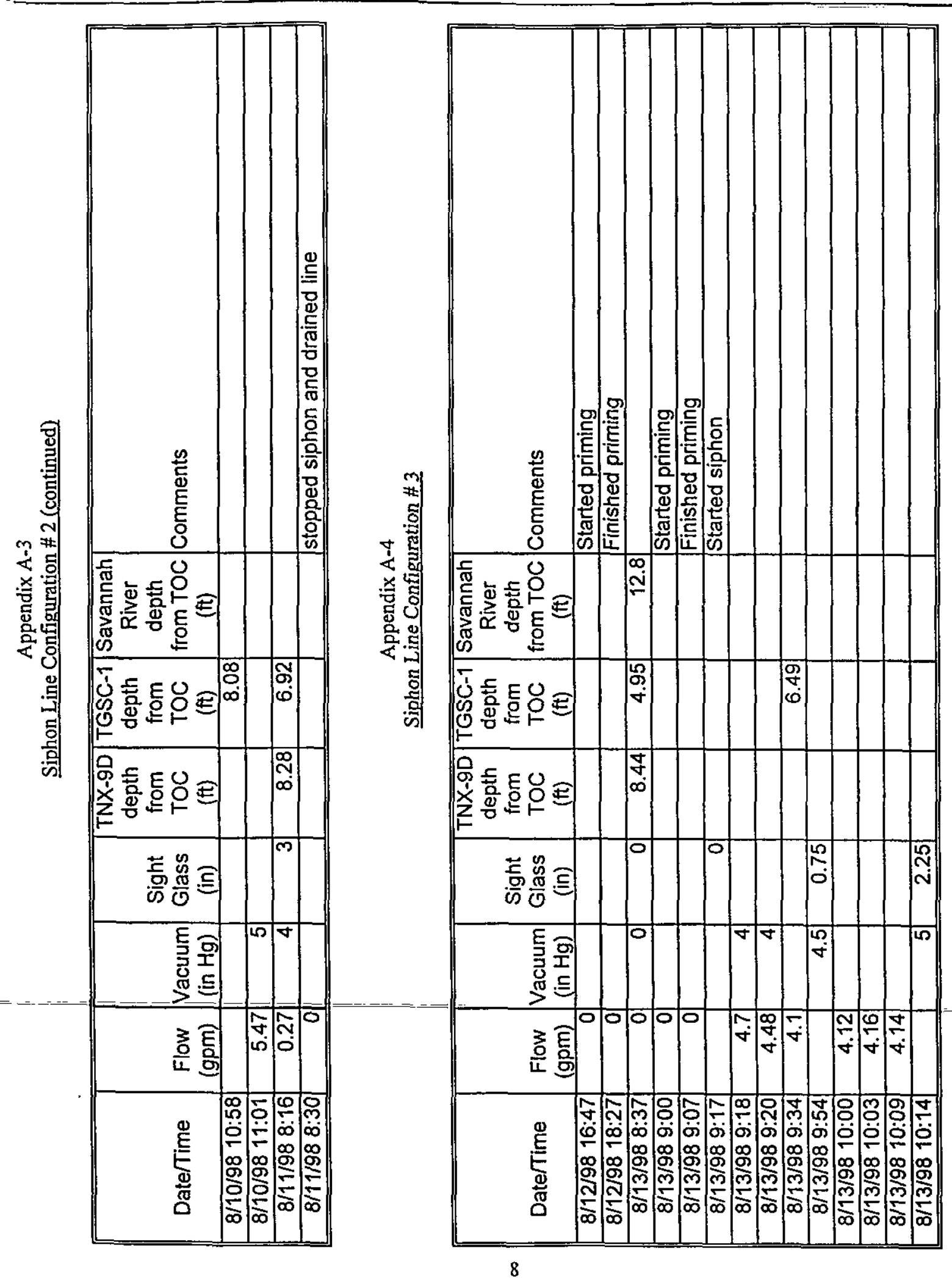


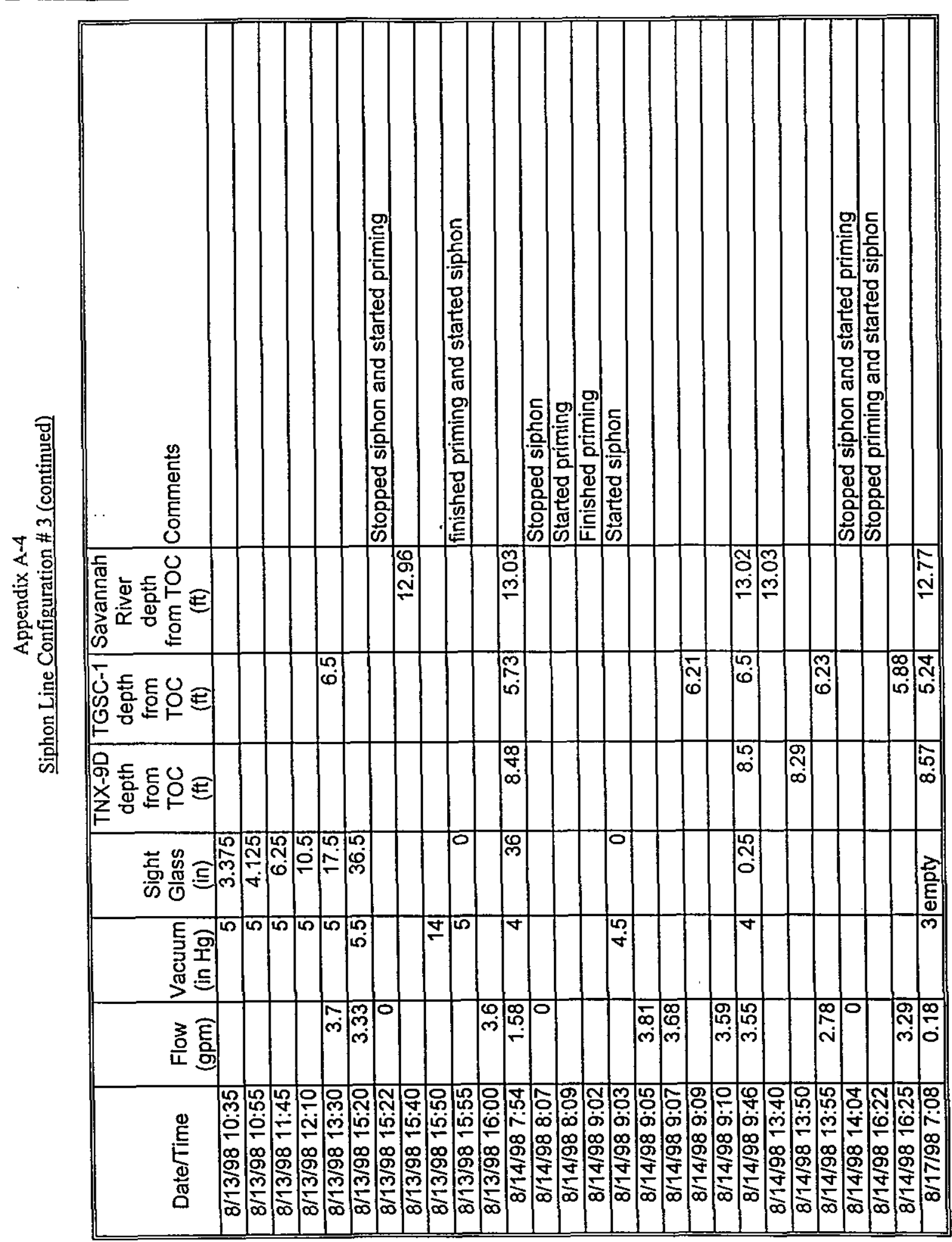




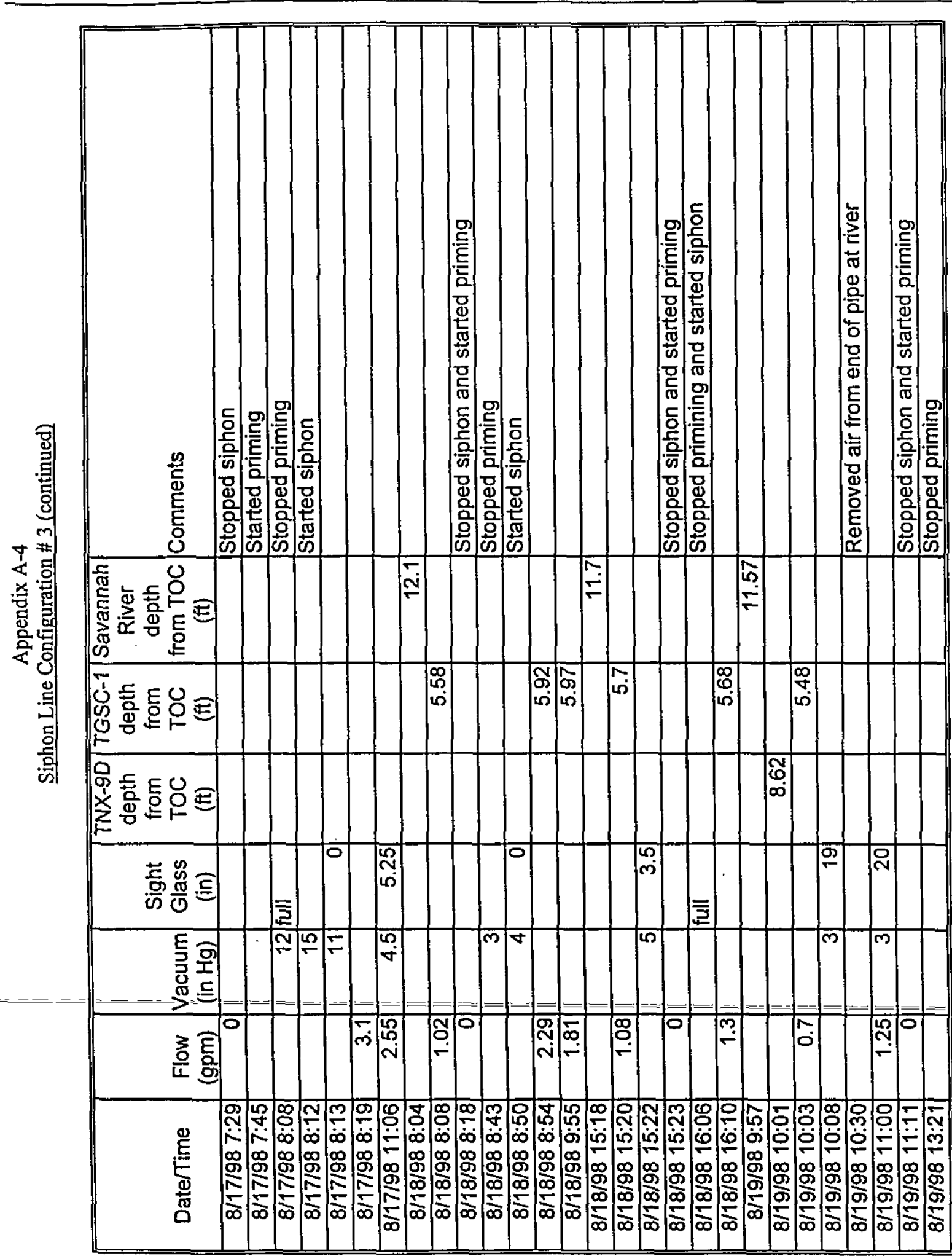




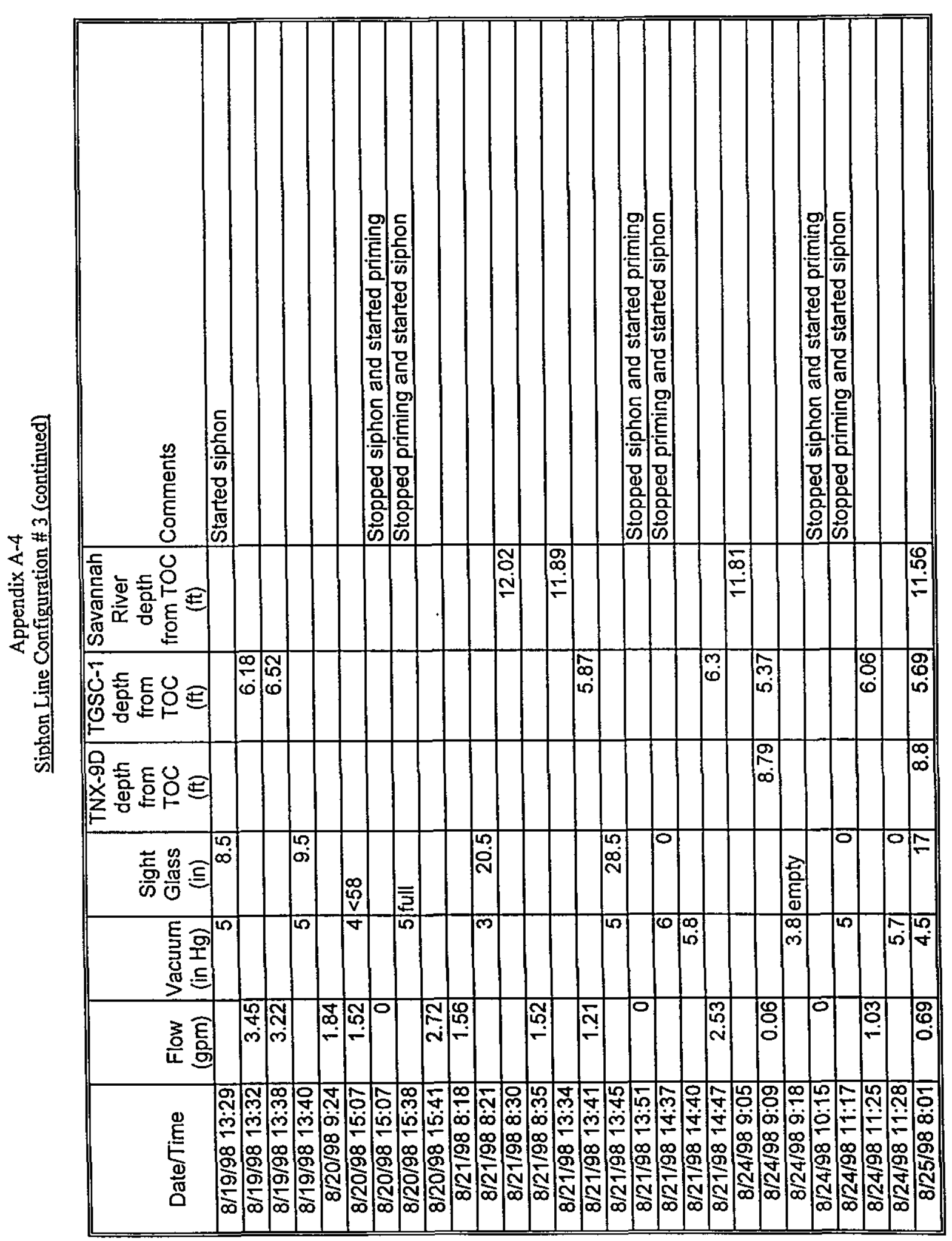




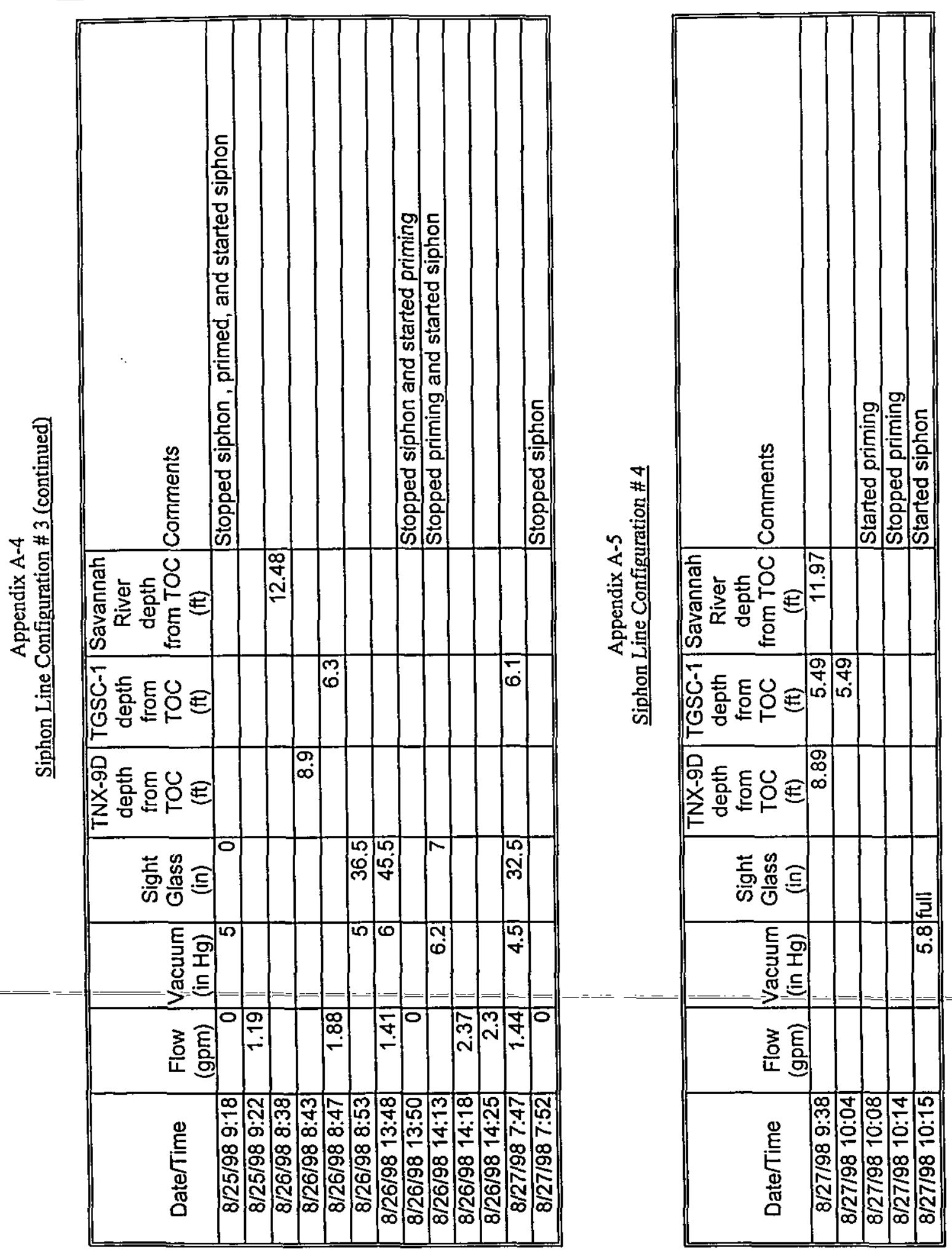




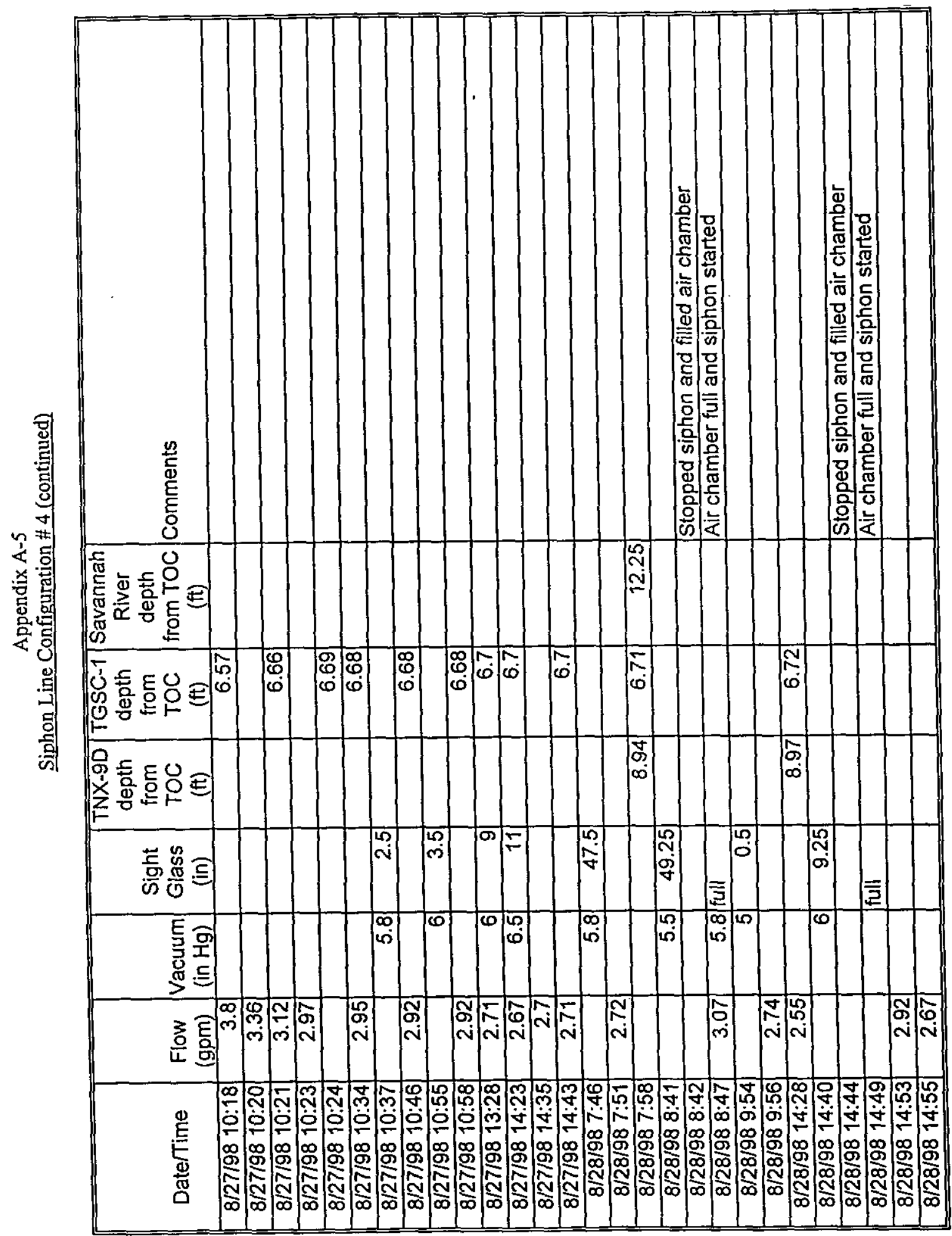




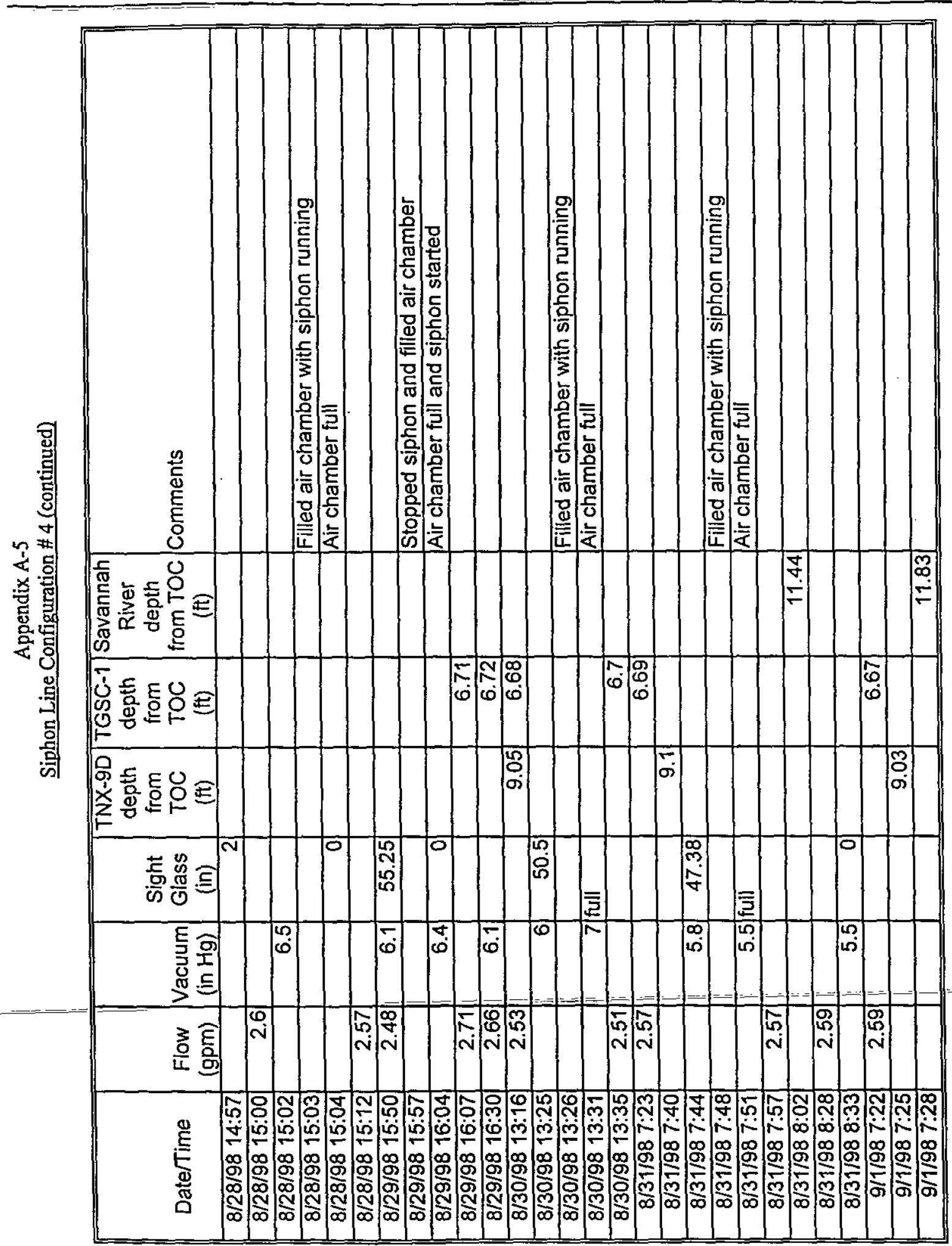




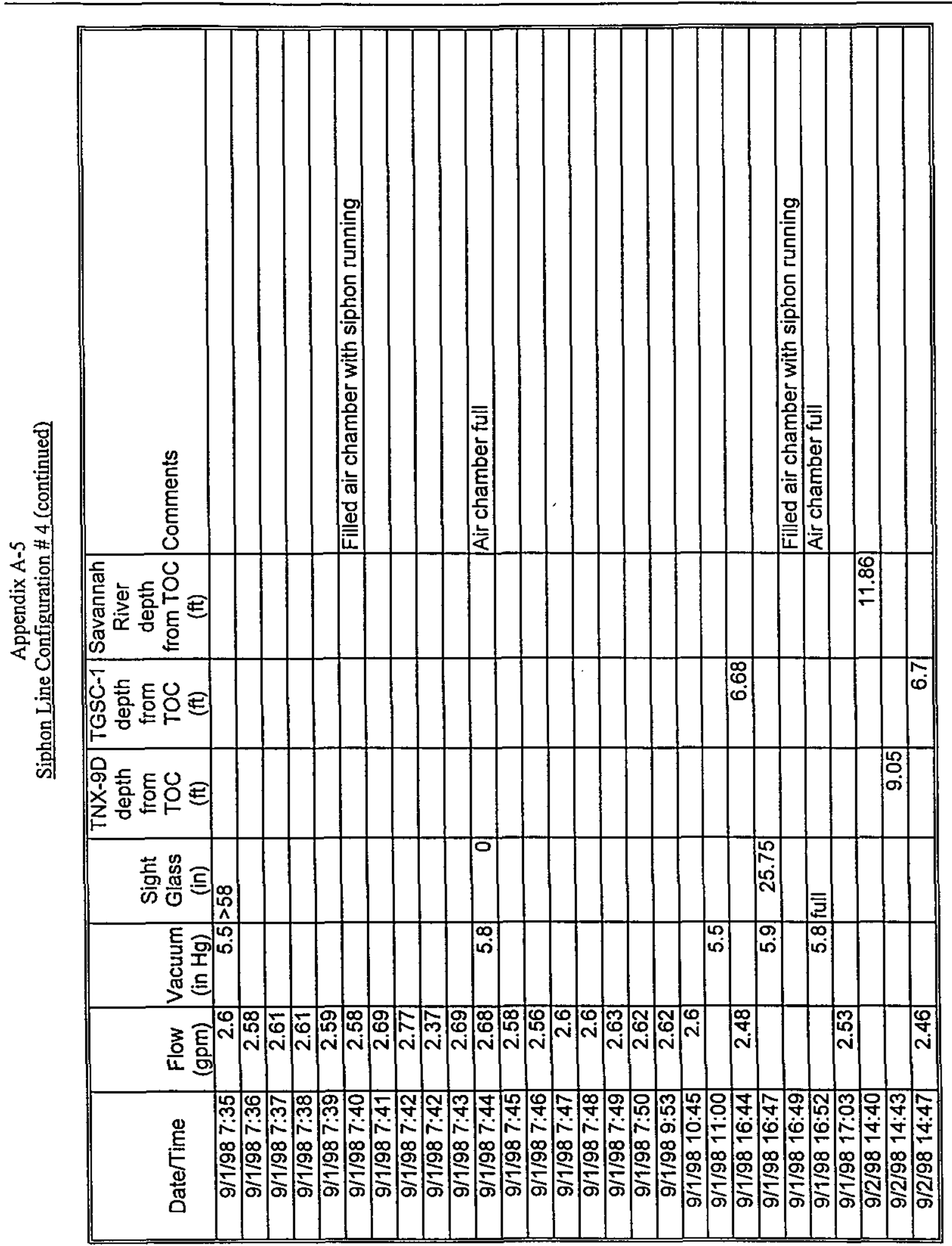




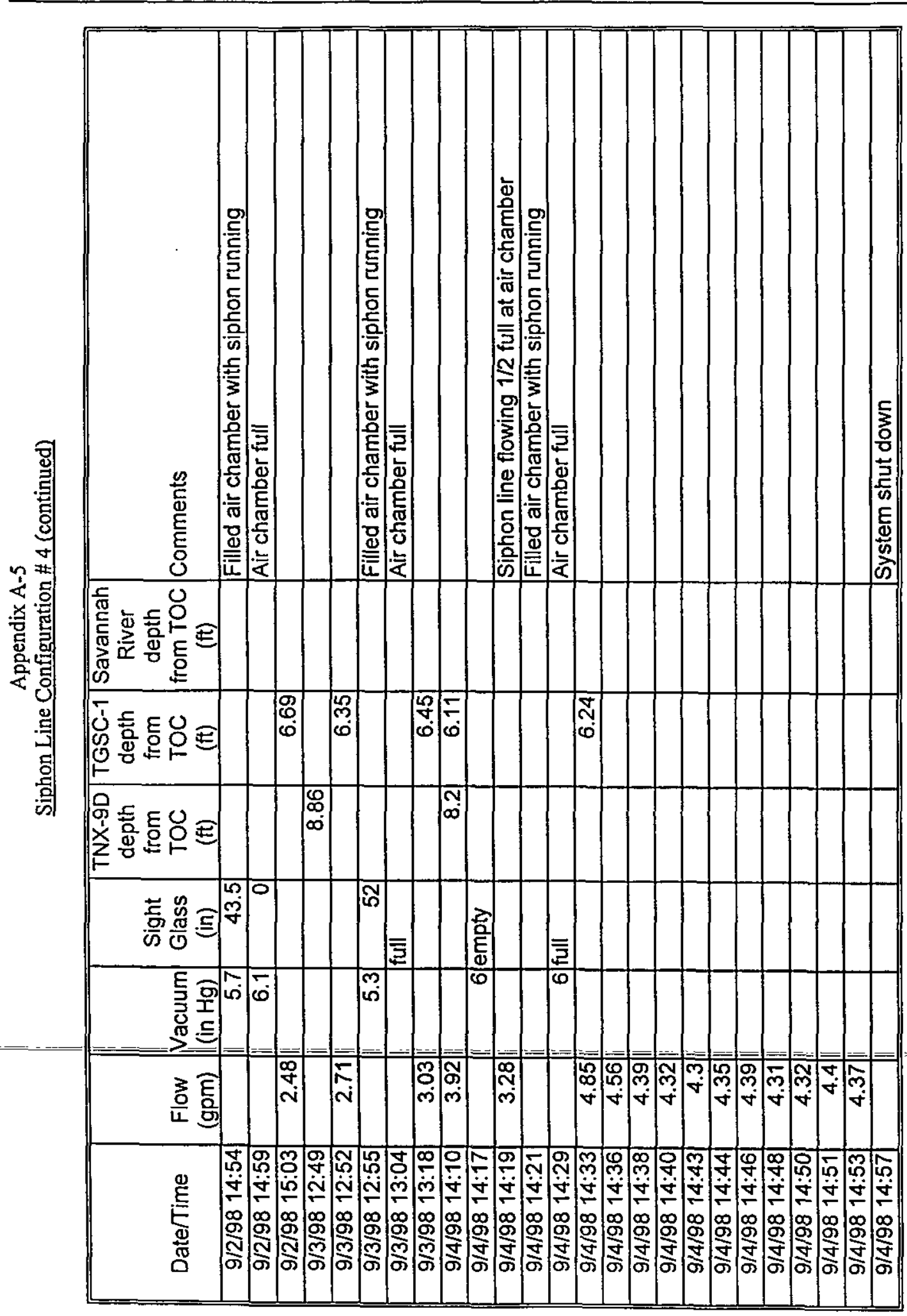


Appendix B

SR-Jackson and SR-TNX Gauging Station Linear Regression Relationship

\begin{tabular}{|c|c|c|c|c|c|c|c|c|c|c|c|}
\hline Date & \begin{tabular}{|c|} 
SR- \\
Jackson \\
Gauging \\
Station \\
Daily \\
Mean \\
Elevation \\
(ft-ms!) \\
\end{tabular} & \begin{tabular}{|l} 
SR-TNX \\
Gauging \\
Station \\
Daily \\
Mean \\
Elevation \\
(ft-msl)
\end{tabular} & Date & \begin{tabular}{|c|} 
SR- \\
Jackson \\
Gauging \\
Station \\
Daily \\
Mean \\
Elevation \\
(ft-msl) \\
\end{tabular} & $\begin{array}{l}\text { SR-TNX } \\
\text { Gauging } \\
\text { Station } \\
\text { Daily } \\
\text { Mean } \\
\text { Elevation } \\
\text { (ft-msl) }\end{array}$ & Date & \begin{tabular}{|c|} 
SR- \\
Jackson \\
Gauging \\
Station \\
Daily \\
Mean \\
Elevation \\
(ft-msl) \\
\end{tabular} & \begin{tabular}{|l} 
SR-TNX \\
Gauging \\
Station \\
Daily \\
Mean \\
Elevation \\
(ft-msi) \\
\end{tabular} & Date & \begin{tabular}{|c|} 
SR- \\
Jackson \\
Gauging \\
Station \\
Daily \\
Mean \\
Elevation \\
(ft-msl) \\
\end{tabular} & \begin{tabular}{|l|} 
SR-TNX \\
Gauging \\
Station \\
Daily \\
Mean \\
Elevation \\
(ft-msl) \\
\end{tabular} \\
\hline $7 / 17 / 97$ & 86.81 & 86.20 & $9 / 22 / 97$ & 82.16 & 81.97 & 11/5/97 & 85.27 & 85.04 & $12 / 20 / 97$ & 90.90 & 90.19 \\
\hline $7 / 18 / 97$ & 86.61 & 86.04 & $9 / 23 / 97$ & 82.53 & 82.31 & $11 / 6 / 97$ & 84.93 & 84.78 & $12 / 21 / 97$ & 90.27 & 90.21 \\
\hline $7 / 19 / 97$ & 86.33 & 85.77 & $9 / 24 / 97$ & 82.76 & 82.54 & $11 / 7 / 97$ & 82.96 & 82.83 & $12 / 22 / 97$ & 89.46 & 88.94 \\
\hline $7 / 20 / 97$ & 84.54 & 84.06 & $9 / 25 / 97$ & 83.19 & 82.87 & $11 / 8 / 97$ & 82.50 & 82.30 & $12 / 23 / 97$ & 90.24 & 89.11 \\
\hline $7 / 21 / 97$ & 84.10 & 83.54 & $9 / 26 / 97$ & 86.12 & 85.73 & $11 / 9197$ & 84.00 & 83.69 & $12 / 24 / 97$ & 91.01 & 89.98 \\
\hline $8 / 14 / 97$ & 87.41 & 87.03 & 9/27/97 & 86.69 & 86.46 & $11 / 10 / 97$ & 83.23 & 83.05 & $12 / 25 / 97$ & 92.65 & 91.07 \\
\hline $8 / 15 / 97$ & 87.42 & 87.12 & $9 / 28 / 97$ & 84.94 & 84.84 & $11 / 11 / 97$ & 83.92 & 83.64 & $12 / 26 / 97$ & 93.91 & 92.84 \\
\hline $8 / 16 / 97$ & 87.17 & 86.90 & $9 / 29 / 97$ & 83.73 & 83.55 & $11 / 12 / 97$ & 83.86 & 83.64 & $12 / 27 / 97$ & 94.48 & 93.80 \\
\hline $8 / 17 / 97$ & 86.03 & 85.82 & $9 / 30 / 97$ & 83.68 & 83.49 & $11 / 13 / 97$ & 84.54 & 84.25 & $12 / 28 / 97$ & 93.78 & 93.68 \\
\hline $8 / 18 / 97$ & 85.42 & 85.14 & $10 / 1 / 97$ & 83.50 & 83.34 & $11 / 14 / 97$ & 86.09 & 85.74 & $12 / 29 / 97$ & 92.36 & 92.25 \\
\hline $8 / 19 / 97$ & 87.28 & 86.87 & $10 / 2 / 97$ & 84.49 & 84.28 & $11 / 15 / 97$ & 89.43 & 88.94 & $12 / 30 / 97$ & 91.79 & 90.72 \\
\hline $8 / 20 / 97$ & 87.37 & 87.14 & $10 / 3 / 97$ & 84.28 & 84.00 & $11 / 16 / 97$ & 90.27 & 90.04 & $12 / 31 / 97$ & 92.84 & 93.58 \\
\hline $8 / 21 / 97$ & 87.02 & 86.73 & $10 / 4 / 97$ & 83.74 & 83.48 & $11 / 17 / 97$ & 86.90 & 86.84 & $4 / 10 / 98$ & 93.89 & 93.00 \\
\hline $8 / 22 / 97$ & 87.09 & 86.79 & $10 / 5 / 97$ & 83.26 & 83.01 & $11 / 18 / 97$ & 85.47 & 85.31 & $4 / 11 / 98$ & 94.93 & 94.00 \\
\hline $8 / 23 / 97$ & 86.73 & 86.52 & $10 / 6 / 97$ & 82.81 & 82.61 & $11 / 19 / 97$ & 86.55 & 86.27 & $4 / 12 / 98$ & 95.34 & 94.51 \\
\hline $8 / 24 / 97$ & 84.93 & 84.71 & $10 / 7 / 97$ & 84.72 & 84.42 & $11 / 20 / 97$ & 85.79 & 85.61 & $4 / 13 / 98$ & 95.48 & 94.79 \\
\hline $8 / 25 / 97$ & 85.49 & 85.17 & $10 / 8 / 97$ & 85.42 & 85.20 & $11 / 21 / 97$ & 84.83 & 84.63 & $4 / 14 / 98$ & 95.50 & 94.86 \\
\hline $8 / 26 / 97$ & 86.45 & 86.15 & 10/9/97 & 85.53 & 85.36 & $11 / 22 / 97$ & 84.32 & 84.15 & $4 / 15 / 98$ & 95.41 & 94.89 \\
\hline $8 / 27 / 97$ & 86.72 & 86.45 & $10 / 10 / 97$ & 84.55 & 84.41 & $11 / 23 / 97$ & 83.77 & 83.57 & $4 / / 6 / 98$ & 94.79 & 94.53 \\
\hline $8 / 28 / 97$ & 86.42 & 86.19 & $10 / 11 / 97$ & 84.23 & 84.06 & $11 / 24 / 97$ & 83.81 & 83.60 & $4 / 17 / 98$ & 94.69 & 94.08 \\
\hline $8 / 29 / 97$ & 85.17 & 84.97 & $10 / 12 / 97$ & 83.50 & 83.40 & $11 / 25 / 97$ & 83.42 & 83.22 & $4 / 18 / 98$ & 95.03 & 94.26 \\
\hline $8 / 30 / 97$ & 84.47 & 84.26 & $10 / 13 / 97$ & 82.81 & 82.48 & $11 / 26 / 97$ & 84.23 & 83.97 & $4 / 19 / 98$ & 95.37 & 94.59 \\
\hline $8 / 31 / 97$ & 83.57 & 83.38 & $10 / 14 / 97$ & 84.46 & 84.16 & $11 / 28 / 97$ & 83.67 & 83.47 & $4 / 20 / 98$ & 95.58 & 94.84 \\
\hline $9 / 1 / 97$ & 83.41 & 83.19 & $10 / 15 / 97$ & 83.70 & 83.54 & $11 / 29 / 97$ & 83.43 & 83.25 & $4 / 21 / 98$ & 95.60 & 94.93 \\
\hline $9 / 2 / 97$ & 83.23 & 83.02 & $10 / 16 / 97$ & 84.69 & 84.46 & $11 / 30 / 97$ & 83.45 & 83.24 & $4 / 22 / 98$ & 95.63 & $\overline{94.93}$ \\
\hline $9 / 3 / 97$ & 83.25 & 83.04 & $10 / 17 / 97$ & 83.76 & 83.67 & $12 / 1 / 97$ & 83.99 & 83.73 & $4 / 23 / 98$ & 95.61 & 94.94 \\
\hline $9 / 4 / 97$ & 83.44 & 83.20 & $10 / 18 / 97$ & 83.42 & 83.23 & $12 / 2 / 97$ & 86.13 & 85.80 & $4 / 24 / 98$ & 95.59 & 94.94 \\
\hline $9 / 5 / 97$ & 83.12 & 82.90 & $10 / 19 / 97$ & 83.79 & 83.61 & $12 / 3 / 97$ & 85.24 & 85.13 & $4 / 25 / 98$ & 95.53 & 94.89 \\
\hline $9 / 6 / 97$ & 82.96 & 82.76 & $10 / 20 / 97$ & 83.39 & 83.20 & $12 / 4 / 97$ & 85.11 & 84.84 & $4 / 26 / 98$ & 95.19 & 94.80 \\
\hline $9 / 7 / 97$ & 82.62 & 82.42 & $10 / 21 / 97$ & 83.65 & 83.45 & $12 / 5 / 97$ & 86.01 & 85.84 & $4 / 27 / 98$ & 94.68 & 94.35 \\
\hline $9 / 8 / 97$ & 82.47 & 82.26 & $10 / 22 / 97$ & 83.39 & 83.19 & $12 / 6 / 97$ & 85.98 & 85.80 & $4 / 28 / 98$ & 94.40 & 93.95 \\
\hline $9 / 9 / 97$ & 82.78 & 82.55 & $10 / 23 / 97$ & 83.77 & 83.53 & $12 / 7 / 97$ & 84.48 & 84.21 & $4 / 29 / 98$ & 94.15 & 93.64 \\
\hline $9 / 10 / 97$ & 83.25 & 83.06 & $10 / 24 / 97$ & 85.20 & 84.88 & $12 / 8 / 97$ & 83.60 & 83.38 & $4 / 30 / 98$ & 94.67 & 93.75 \\
\hline $9 / 11 / 97$ & 82.68 & 82.45 & $10 / 25 / 97$ & 85.26 & 85.08 & $12 / 9 / 97$ & 84.64 & 84.36 & $5 / 1 / 98$ & 95.22 & 94.42 \\
\hline
\end{tabular}


Appendix B (continued)

SR-Jackson and SR-TNX Gauging Station Linear Regression Relationship

\begin{tabular}{|c|c|c|c|c|c|c|c|c|c|c|c|}
\hline Date & \begin{tabular}{|c|} 
SR- \\
Jackson \\
Gauging \\
Station \\
Daily \\
Mean \\
Elevation \\
(ft-msl) \\
\end{tabular} & $\begin{array}{l}\text { SR-TNX } \\
\text { Gauging } \\
\text { Station } \\
\text { Daily } \\
\text { Mean } \\
\text { Elevation } \\
\text { (ft-msl) }\end{array}$ & Date & \begin{tabular}{|c|} 
SR- \\
Jackson \\
Gauging \\
Station \\
Daily \\
Mean \\
Elevation \\
(ft-msI) \\
\end{tabular} & \begin{tabular}{|l} 
SR-TNX \\
Gauging \\
Station \\
Daily \\
Mean \\
Elcvation \\
(ft-msl) \\
\end{tabular} & Date & \begin{tabular}{|c|} 
SR- \\
Jackson \\
Gauging \\
Station \\
Daily \\
Mean \\
Elevation \\
(ft-msl) \\
\end{tabular} & $\begin{array}{l}\text { SR-TNX } \\
\text { Gauging } \\
\text { Station } \\
\text { Daily } \\
\text { Mean } \\
\text { Elevation } \\
(\mathrm{ft}-\mathrm{msl}) \\
\end{array}$ & Date & \begin{tabular}{|c|} 
SR- \\
Jackson \\
Gauging \\
Station \\
Daily \\
Mean \\
Elevation \\
(ft-msl) \\
\end{tabular} & $\begin{array}{l}\text { SR-TNX } \\
\text { Gauging } \\
\text { Station } \\
\text { Daily } \\
\text { Mean } \\
\text { Elevation } \\
\text { (ft-msl) }\end{array}$ \\
\hline $9 / 12 / 97$ & 83.05 & 82.83 & $10 / 26 / 97$ & 83.83 & 83.67 & $12 / 10 / 97$ & 84.21 & 83.99 & $5 / 2 / 98$ & 95.42 & 94.67 \\
\hline $9 / 13 / 97$ & 82.95 & 82.76 & $10 / 27 / 97$ & 85.14 & 84.86 & $12 / 11 / 97$ & 84.76 & 84.62 & $5 / 3 / 98$ & 95.53 & 94.80 \\
\hline $9 / 14 / 97$ & 82.64 & 82.45 & $10 / 28 / 97$ & 88.50 & 88.02 & $12 / 12 / 97$ & 85.55 & 85.32 & $5 / 4 / 98$ & 95.52 & 94.87 \\
\hline 9/15/97 & 82.72 & 82.50 & $10 / 29 / 97$ & 88.83 & 88.68 & $12 / 13 / 97$ & 85.17 & 84.95 & $5 / 5 / 98$ & 95.37 & 94.79 \\
\hline 9/16/97 & 83.47 & 83.22 & $10 / 30 / 97$ & 86.50 & 86.35 & $12 / 14 / 97$ & 85.62 & 85.36 & $5 / 6 / 98$ & 95.26 & 94.64 \\
\hline 9/17/97 & 83.46 & 83.25 & $10 / 31 / 97$ & 85.52 & 85.34 & $12 / 15 / 97$ & 85.90 & 85.65 & $5 / 7 / 98$ & 95.25 & 94.58 \\
\hline $9 / 18 / 97$ & 83.50 & 83.28 & $11 / 1 / 97$ & 84.17 & 84.03 & $12 / 16 / 97$ & 86.73 & 87.69 & $5 / 8 / 98$ & 95.38 & 94.63 \\
\hline $9 / 19 / 97$ & 83.24 & 83.07 & $11 / 2 / 97$ & 83.89 & 83.70 & $12 / 17 / 97$ & 89.98 & 89.68 & $5 / 9 / 98$ & 95.18 & 94.73 \\
\hline $9 / 20 / 97$ & 82.99 & 82.79 & $11 / 3 / 97$ & 84.05 & 83.83 & $12 / 18 / 97$ & 90.24 & 89.97 & $5 / 10 / 98$ & 93.93 & 94.24 \\
\hline $9 / 21 / 97$ & 82.88 & 82.72 & $11 / 4 / 97$ & 84.62 & 84.36 & $12 / 19 / 97$ & 90.54 & 90.05 & $5 / 11 / 98$ & 90.90 & 92.39 \\
\hline
\end{tabular}

\begin{tabular}{||c|c|c|}
\hline \multicolumn{3}{|c|}{ Linear Regression } \\
\hline Slope & Intercept & r Square \\
\hline 0.96550 & 2.68956 & 0.99607 \\
\hline
\end{tabular}

\begin{tabular}{|c|}
\hline Best Fit Equation \\
\hline SR-TNX $=0.96550$ (SR-Jackson) +2.68 \\
\hline
\end{tabular}

\begin{tabular}{||c|c|c|c||}
\hline \multicolumn{4}{|c|}{ SR-TNX Daily Mean Elevation Statistics } \\
\hline Mean & Median & Minimum & Maximum \\
\hline 86.81 & 85.06 & 81.97 & 94.94 \\
\hline
\end{tabular}


Appendix C

SR-TNX Estimated Historic Daily Mean Elevation

\begin{tabular}{|c|c|c|c|c|c|c|c|c|c|c|c|}
\hline Date & \begin{tabular}{|c|} 
SR- \\
Jackson \\
Gauging \\
Station \\
Daily \\
Mean \\
Elevation \\
(ft-ms!)
\end{tabular} & $\begin{array}{l}\text { SR-TNX } \\
\text { Estimated } \\
\text { Daily } \\
\text { Mean } \\
\text { Elevation } \\
\text { (ft-ms!) }\end{array}$ & Date & \begin{tabular}{|c|} 
SR- \\
Jackson \\
Gauging \\
Station \\
Daily \\
Mean \\
Elevation \\
(ft-msl) \\
\end{tabular} & $\begin{array}{c}\text { SR-TNX } \\
\text { Estimated } \\
\text { Daily } \\
\text { Mean } \\
\text { Elevation } \\
\text { (ft-msl) }\end{array}$ & Date & \begin{tabular}{|c|} 
SR- \\
Jackson \\
Gauging \\
Station \\
Daily \\
Mean \\
Elevation \\
(ft-msl)
\end{tabular} & $\begin{array}{l}\text { SR-TNX } \\
\text { Estimated } \\
\text { Daily } \\
\text { Mean } \\
\text { Elevation } \\
\text { (ft-msl) }\end{array}$ & Date & $\begin{array}{c}\text { SR- } \\
\text { Jackson } \\
\text { Gauging } \\
\text { Station } \\
\text { Daily } \\
\text { Mean } \\
\text { Elevation } \\
\text { (ft-msl) }\end{array}$ & $\begin{array}{c}\text { SR-TNX } \\
\text { Estimated } \\
\text { Daily } \\
\text { Mean } \\
\text { Elevation } \\
\text { (ft-msl) }\end{array}$ \\
\hline 10/1/87 & 89.21 & 88.82 & $5 / 29 / 90$ & \begin{tabular}{l|}
87.07 \\
\end{tabular} & 86.76 & $1 / 24 / 93$ & 95.01 & 94.42 & $9 / 22 / 95$ & 85.30 & 85.05 \\
\hline $10 / 2 / 87$ & & & $5 / 30 / 90$ & 89.98 & 89.56 & $1 / 25 / 93$ & 95.69 & 95.08 & $9 / 23 / 95$ & 86.92 & 86.61 \\
\hline $10 / 3 / 87$ & & & $5 / 31 / 90$ & 90.74 & 90.30 & $1 / 26 / 93$ & 96.14 & 95.51 & $9 / 24 / 95$ & 88.17 & 87.82 \\
\hline $10 / 4 / 87$ & & & $6 / 1 / 90$ & 90.02 & 89.60 & $1 / 27 / 93$ & 96.30 & 95.67 & $9 / 25 / 95$ & 89.39 & 89.00 \\
\hline $10 / 5 / 87$ & 83.83 & 83.63 & $6 / 2 / 90$ & 89.76 & 89.35 & $1 / 28 / 93$ & 96.31 & 95.68 & $9 / 26 / 95$ & 89.50 & 89.10 \\
\hline $10 / 6 / 87$ & 84.81 & 84.57 & $6 / 3 / 90$ & 87.43 & 87.10 & $1 / 29 / 93$ & 96.30 & 95.67 & $9 / 27 / 95$ & 88.76 & 88.39 \\
\hline $10 / 7 / 87$ & 85.75 & 85.48 & $6 / 4 / 90$ & 84.75 & 84.52 & $1 / 30 / 93$ & 96.27 & 95.64 & 9/28/95 & 87.33 & 87.01 \\
\hline \begin{tabular}{|l|}
$10 / 8 / 87$ \\
\end{tabular} & 85.44 & \begin{tabular}{l|l}
85.18 \\
\end{tabular} & $6 / 5 / 90$ & 84.20 & 83.98 & $1 / 31 / 93$ & 95.81 & 95.19 & $9 / 29 / 95$ & 86.86 & 86.53 \\
\hline 10/9/87 & 84.95 & 84.71 & $6 / 6 / 90$ & 83.81 & 83.61 & $2 / 193$ & 95.28 & 94.68 & $9 / 30 / 95$ & 87.04 & 86.73 \\
\hline $10 / 10 / 87$ & 85.09 & 84.84 & $6 / 7 / 90$ & 83.69 & 83.49 & $2 / 2 / 93$ & 94.91 & 94.32 & $10 / 1 / 95$ & 86.61 & 86.31 \\
\hline $10 / 11 / 87$ & 84.01 & 83.80 & $6 / 8 / 90$ & 83.45 & 83.26 & $2 / 3 / 93$ & 94.71 & 94.13 & $10 / 2 / 95$ & 85.24 & 84.99 \\
\hline $10 / 12 / 87$ & 83.42 & \begin{tabular}{l|l}
83.23 \\
\end{tabular} & $6 / 9 / 90$ & 84.73 & 84.50 & $2 / 4 / 93$ & 94.61 & 94.04 & $10 / 3 / 95$ & 84.46 & 84.24 \\
\hline $10 / 13 / 87$ & 84.11 & 83.90 & $6 / 10 / 90$ & 84.99 & 84.75 & $2 / 5 / 93$ & 94.71 & 94.13 & $10 / 4 / 95$ & 86.96 & 86.65 \\
\hline $10 / 14 / 87$ & 85.67 & 85.40 & $6 / 11 / 90$ & 84.57 & 84.34 & $2 / 6 / 93$ & 94.89 & 94.31 & $10 / 5 / 95$ & 88.10 & 87.75 \\
\hline $10 / 15 / 87$ & 86.07 & 85.79 & $6 / 12 / 90$ & 83.86 & 83.66 & $2 / 7 / 93$ & 94.26 & 93.70 & $10 / 6 / 95$ & 88.07 & 87.72 \\
\hline $10 / 16 / 87$ & 85.61 & 85.35 & $6 / 13 / 90$ & 83.27 & 83.09 & $2 / 8 / 93$ & 92.96 & 92.44 & $10 / 7 / 95$ & 87.93 & 87.59 \\
\hline $10 / 17 / 87$ & 84.72 & 84.49 & $6 / 14 / 90$ & 83.29 & 83.11 & $2 / 9 / 93$ & 93.22 & 92.69 & $10 / 8 / 95$ & 86.36 & 86.07 \\
\hline $10 / 18 / 87$ & 84.27 & 84.05 & $6 / 15 / 90$ & 84.92 & 84.68 & $2 / 10 / 93$ & 93.91 & 93.36 & 10/9/95 & 84.67 & 84.44 \\
\hline $10 / 19 / 87$ & 83.36 & 83.17 & $6 / 16 / 90$ & 84.48 & 84.25 & $2 / 11 / 93$ & 94.75 & 94.17 & $10 / 10 / 95$ & 83.73 & 83.53 \\
\hline $10 / 20 / 87$ & 83.46 & 83.27 & $6 / 17 / 90$ & 83.35 & 83.16 & $2 / 12 / 93$ & 95.15 & 94.56 & $10 / 11 / 95$ & 84.92 & 84.68 \\
\hline $10 / 21 / 87$ & 83.46 & 83.27 & $6 / 18 / 90$ & 83.40 & 83.21 & $2 / 13 / 93$ & 95.21 & 94.61 & $10 / 12 / 95$ & 84.90 & 84.66 \\
\hline $10 / 22 / 87$ & 82.57 & 82.41 & $6 / 19 / 90$ & 84.28 & 84.06 & $2 / 14 / 93$ & 95.25 & 94.65 & $10 / 13 / 95$ & 85.86 & 85.59 \\
\hline $10 / 23 / 87$ & 83.60 & 83.41 & $6 / 20 / 90$ & 85.46 & 85.20 & $2 / 15 / 93$ & 95.23 & 94.63 & $10 / 14 / 95$ & 86.49 & 86.20 \\
\hline $10 / 24 / 87$ & 84.82 & 84.58 & $6 / 21 / 90$ & 85.92 & 85.65 & $2 / 16 / 93$ & 95.18 & 94.59 & $10 / 15 / 95$ & 85.96 & 85.68 \\
\hline $10 / 25 / 87$ & 83.68 & 83.48 & $6 / 22190$ & 86.11 & 85.83 & $2 / 17 / 93$ & 95.17 & 94.58 & $10 / 16 / 95$ & 85.31 & 85.06 \\
\hline $10 / 26 / 87$ & 83.01 & 82.84 & $6 / 23 / 90$ & 84.38 & 84.16 & 2/18/93 & 95.24 & 94.64 & $10 / 17 / 95$ & 85.74 & 85.47 \\
\hline $10 / 27 / 87$ & 83.47 & 83.28 & $6 / 24 / 90$ & 83.18 & 83.00 & $2 / 19 / 93$ & 95.28 & 94.68 & $10 / 18 / 95$ & 87.47 & 87.14 \\
\hline $10 / 28 / 87$ & 84.80 & 84.56 & $6 / 25 / 90$ & 83.32 & 83.13 & $2 / 20 / 93$ & 95.23 & 94.63 & $10 / 19 / 95$ & 89.20 & 88.81 \\
\hline $10 / 29 / 87$ & 85.25 & 85.00 & $6 / 26 / 90$ & 84.73 & 84.50 & $2 / 21 / 93$ & 95.15 & 94.56 & $10 / 20 / 95$ & 91.57 & $\overline{91.10}$ \\
\hline $10 / 30 / 87$ & 84.49 & 84.26 & $6 / 27 / 90$ & 85.28 & 85.03 & $2 / 22 / 93$ & 95.11 & 94.52 & $10 / 21 / 95$ & 92.26 & 91.77 \\
\hline $10 / 31 / 87$ & 83.89 & 83.69 & $6 / 28 / 90$ & 84.12 & 83.91 & $2 / 23 / 93$ & 95.13 & 94.54 & $10 / 22 / 95$ & 91.89 & 91.41 \\
\hline T1/1/87 & 83.31 & 83.13 & $6 / 29 / 90$ & 83.58 & 83.39 & $2 / 24 / 93$ & 95.22 & 94.62 & $10 / 23 / 95$ & 92.02 & 91.53 \\
\hline $11 / 2 / 87$ & 83.29 & 83.11 & $6 / 30 / 90$ & 83.10 & 82.92 & $2 / 25 / 93$ & 95.07 & 94.48 & $10 / 24 / 95$ & 91.96 & 91.48 \\
\hline $11 / 3 / 87$ & 83.78 & 83.58 & $7 / 1 / 90$ & 82.86 & 82.69 & $2 / 26 / 93$ & 94.85 & 94.27 & $10 / 25 / 95$ & 92.29 & 91.80 \\
\hline $11 / 4 / 87$ & 84.11 & 83.90 & $7 / 2 / 90$ & 82.95 & 82.78 & $2 / 27 / 93$ & 94.91 & 94.32 & $10 / 26 / 95$ & 91.52 & 91.05 \\
\hline 11/5/87 & 84.03 & 83.82 & $7 / 3 / 90$ & 84.02 & 83.81 & $2 / 28 / 93$ & 95.03 & 94.44 & $10 / 27 / 95$ & 90.65 & 90.21 \\
\hline $11 / 6 / 87$ & 83.46 & 83.27 & $7 / 4 / 90$ & 84.14 & 83.93 & $3 / 1 / 93$ & 95.10 & 94.51 & $10 / 28 / 95$ & 89.59 & 89.19 \\
\hline $11 / 7 / 87$ & 83.91 & 83.70 & $7 / 5 / 90$ & 83.74 & 83.54 & $3 / 2 / 93$ & 95.11 & 94.52 & $10 / 29 / 95$ & 87.87 & 87.53 \\
\hline $11 / 8 / 87$ & 83.58 & 83.39 & $7 / 6 / 90$ & 85.28 & 85.03 & $3 / 3 / 93$ & 95.11 & 94.52 & $10 / 30 / 95$ & 86.56 & 86.26 \\
\hline
\end{tabular}


Appendix C (continued)

SR-TNX Estimated Historic Daily Mean Elevation

\begin{tabular}{|c|c|c|c|c|c|c|c|c|c|c|c|}
\hline Date & \begin{tabular}{|c|} 
SR- \\
Jackson \\
Elevation \\
$(\mathrm{f}-\mathrm{ms})$ \\
\end{tabular} & \begin{tabular}{c|} 
SR-TNX \\
Estimated \\
Elevation \\
(ft-msl)
\end{tabular} & Date & \begin{tabular}{|c|} 
SR- \\
Jackson \\
Elevation \\
(ft-mst) \\
\end{tabular} & $\begin{array}{l}\text { SR-TNX } \\
\text { Estimated } \\
\text { Elevation } \\
\text { (ft-msl) } \\
\end{array}$ & Datc & \begin{tabular}{|c|} 
SR- \\
Jackson \\
Elevation \\
(ft-msl)
\end{tabular} & $\begin{array}{l}\text { SR-TNX } \\
\text { Estimated } \\
\text { Elevation } \\
\text { (ft-msl) }\end{array}$ & Date & \begin{tabular}{|c|} 
SR- \\
Jackson \\
Elevation \\
(f-msl)
\end{tabular} & \begin{tabular}{|c|} 
SR-TNXX \\
Estimated \\
Elevation \\
(ft-msl)
\end{tabular} \\
\hline $11 / 9 / 87$ & 82.92 & 82.75 & $7 / 7 / 90$ & 85.55 & 85.29 & $3 / 4 / 93$ & 94.71 & 94.13 & $10 / 31 / 95$ & 85.17 & 84.92 \\
\hline $11 / 10 / 87$ & 82.91 & 82.74 & $7 / 8 / 90$ & 83.41 & 83.22 & $3 / 5 / 93$ & \begin{tabular}{|c|}
94.23 \\
\end{tabular} & 93.67 & $11 / 1 / 95$ & 85.97 & 85.69 \\
\hline $11 / 11 / 87$ & 83.46 & 83.27 & 719190 & 83.08 & 82.90 & $3 / 6 / 93$ & 94.37 & 93.80 & $11 / 2 / 95$ & 86.92 & 86.61 \\
\hline $11 / 12 / 87$ & 84.36 & 84.14 & $7 / 10 / 90$ & 84.79 & 84.55 & $3 / 7 / 93$ & 94.10 & 93.54 & $11 / 3 / 95$ & 86.94 & 86.63 \\
\hline $11 / 13 / 87$ & 86.37 & 86.08 & $7 / 11 / 90$ & 85.83 & 85.56 & $3 / 8 / 93$ & 92.88 & 92.36 & $11 / 4 / 95$ & 87.45 & 87.12 \\
\hline $11 / 14 / 87$ & 85.04 & 84.80 & $7 / 12 / 90$ & 86.13 & 85.85 & $3 / 9 / 93$ & 91.24 & 90.78 & $11 / 5 / 95$ & 85.74 & 85.47 \\
\hline $11 / 15 / 87$ & 83.53 & 83.34 & $7 / 13 / 90$ & 85.75 & 85.48 & $3 / 10 / 93$ & 91.20 & 90.74 & $11 / 6 / 95$ & 86.82 & 86.51 \\
\hline $11 / 16 / 87$ & 82.60 & 82.44 & $7 / 14 / 90$ & 83.96 & 83.75 & $3 / 11 / 93$ & 92.16 & 91.67 & $11 / 7 / 95$ & 87.54 & 87.21 \\
\hline $11 / 17 / 87$ & 82.24 & 82.09 & $7 / 15 / 90$ & 82.80 & 82.63 & $3 / 12 / 93$ & \begin{tabular}{l|l|}
93.03 \\
\end{tabular} & 92.51 & $11 / 8 / 95$ & 88.63 & 88.26 \\
\hline $111 / 18 / 87$ & 84.23 & 84.01 & $7 / 16 / 90$ & 82.69 & 82.53 & $3 / 13 / 93$ & 93.79 & 93.24 & $11 / 9 / 95$ & 89.87 & 89.46 \\
\hline $11 / 19 / 87$ & 84.87 & 84.63 & $7 / 17 / 90$ & 82.85 & 82.68 & $3 / 14 / 93$ & 94.42 & 93.85 & $11 / 10 / 95$ & 91.34 & 90.88 \\
\hline $11 / 20 / 87$ & 83.48 & 83.29 & $7 / 18 / 90$ & 83.99 & 83.78 & $3 / 15 / 93$ & 95.04 & 94.45 & $11 / 11 / 95$ & 91.86 & 91.38 \\
\hline $11 / 21 / 87$ & 83.94 & 83.73 & $7 / 19 / 90$ & 85.68 & 85.41 & $3 / 16 / 93$ & 95.48 & 94.88 & $11 / 12 / 95$ & 92.29 & 91.80 \\
\hline $11 / 22 / 87$ & 84.16 & 83.95 & $7 / 20 / 90$ & 84.41 & 84.19 & $3 / 17 / 93$ & 95.56 & 94.95 & $11 / 13 / 95$ & 93.04 & 92.52 \\
\hline $11 / 23 / 87$ & 83.10 & 82.92 & $7 / 21 / 90$ & 83.46 & 83.27 & $3 / 18 / 93$ & 95.44 & 94.84 & $11 / 14 / 95$ & 93.57 & 93.03 \\
\hline $11 / 24 / 87$ & 82.44 & 82.29 & $7 / 22 / 90$ & 83.85 & 83.65 & $3 / 19 / 93$ & 95.31 & 94.71 & $11 / 15 / 95$ & 94.04 & $\begin{array}{l}93.48 \\
\end{array}$ \\
\hline $11 / 25 / 87$ & 82.82 & 82.65 & $7 / 23 / 90$ & 83.82 & 83.62 & $3 / 20 / 93$ & 95.23 & 94.63 & $11 / 16 / 95$ & 94.58 & 94.01 \\
\hline $11 / 26 / 87$ & 83.26 & 83.08 & $7 / 24 / 90$ & 85.64 & 85.37 & $3 / 21 / 93$ & 95.12 & 94.53 & $11 / 17 / 95$ & 94.97 & 94.38 \\
\hline $11 / 27 / 87$ & 83.44 & 83.25 & $7 / 25 / 90$ & 86.43 & 86.14 & $3 / 22293$ & 94.53 & 93.96 & $11 / 18 / 95$ & 95.15 & 94.56 \\
\hline $11 / 28 / 87$ & 84.40 & 84.18 & $7 / 26 / 90$ & 85.78 & 85.51 & $3 / 23 / 93$ & 94.33 & 93.76 & $11 / 19 / 95$ & 95.23 & 94.63 \\
\hline $11 / 29 / 87$ & 84.78 & 84.54 & $7 / 27 / 90$ & 85.45 & 85.19 & $3 / 24 / 93$ & 94.85 & 94.27 & $11 / 20 / 95$ & 95.25 & 94.65 \\
\hline $11 / 30 / 87$ & 83.42 & 83.23 & $7 / 28 / 90$ & 84.37 & 84.15 & $3 / 25 / 93$ & 95.42 & 94.82 & $11 / 21 / 95$ & 95.25 & 94.65 \\
\hline $12 / 1 / 87$ & 82.53 & 82.37 & $7 / 29 / 90$ & 83.07 & 82.89 & $3 / 26 / 93$ & 95.70 & 95.09 & $11 / 22 / 95$ & 95.06 & $\begin{array}{l}94.47 \\
\end{array}$ \\
\hline $12 / 2 / 87$ & 83.00 & 82.83 & $7 / 30 / 90$ & 83.10 & 82.92 & $3 / 27 / 93$ & 95.75 & 95.14 & $11 / 23 / 95$ & 94.67 & 94.09 \\
\hline $12 / 3 / 87$ & 83.59 & 83.40 & $7 / 31 / 90$ & 85.49 & 85.23 & $3 / 28 / 93$ & 95.65 & 95.04 & $11 / 24 / 95$ & 94.39 & 93.82 \\
\hline $12 / 4 / 87$ & 83.37 & 83.18 & $8 / 190$ & 85.97 & 85.69 & $3 / 29 / 93$ & 95.76 & 95.15 & $11 / 25 / 95$ & 94.30 & 93.74 \\
\hline $12 / 5 / 87$ & 83.12 & 82.94 & $8 / 2 / 90$ & 86.38 & 86.09 & $3 / 30 / 93$ & 95.94 & 95.32 & $11 / 26 / 95$ & 94.26 & 93.70 \\
\hline $12 / 6 / 87$ & 83.00 & 82.83 & $8 / 3 / 90$ & 86.73 & 86.43 & $3 / 31 / 93$ & 95.82 & 95.20 & $11 / 27 / 95$ & 94.24 & 93.68 \\
\hline $12 / 7 / 87$ & 82.63 & 82.47 & $8 / 4 / 90$ & 86.04 & 85.76 & $4 / 1 / 93$ & 95.72 & 95.11 & $11 / 28 / 95$ & 94.25 & 93.69 \\
\hline $12 / 8 / 87$ & 82.18 & 82.03 & $8 / 5 / 90$ & 83.63 & 83.43 & $4 / 2 / 93$ & 95.71 & 95.10 & $11 / 29 / 95$ & 94.19 & 93.63 \\
\hline $12 / 9 / 87$ & 82.37 & 82.22 & $8 / 6 / 90$ & 83.35 & 83.16 & $4 / 3 / 93$ & 95.66 & 95.05 & $11 / 30 / 95$ & 94.06 & 93.50 \\
\hline $12 / 10 / 87$ & 82.85 & 82.68 & $8 / 7 / 90$ & 84.85 & 84.61 & $4 / 4 / 93$ & 95.50 & 94.89 & $12 / 1 / 95$ & 94.02 & $\begin{array}{l}93.47 \\
\end{array}$ \\
\hline $12 / 11 / 87$ & 83.42 & 83.23 & $8 / 8 / 90$ & 86.04 & 85.76 & $4 / 5 / 93$ & 95.40 & 94.80 & $12 / 2195$ & 93.82 & 93.27 \\
\hline $12 / 12 / 87$ & 83.75 & 83.55 & $8 / 9190$ & 86.71 & 86.41 & $4 / 6 / 93$ & 95.42 & 94.82 & $12 / 3 / 95$ & 91.64 & 91.17 \\
\hline $12 / 13 / 87$ & 83.10 & 82.92 & $8 / 10 / 90$ & 87.18 & 86.86 & $4 \pi / 93$ & 95.61 & 95.00 & $12 / 4 / 95$ & 88.69 & 88.33 \\
\hline \begin{tabular}{|l|l|l|l|} 
\\
\end{tabular} & 82.16 & 82.01 & $8 / 11 / 90$ & 85.48 & $85 . \overline{22}$ & $4 / 8 / 93$ & $\overline{95.68}$ & 95.07 & $12 / 5 / 95$ & 90.24 & 89.82 \\
\hline $12 / 15 / 87$ & 82.08 & 81.94 & $8 / 12 / 90$ & 83.53 & 83.34 & $4 / 9 / 93$ & 95.59 & 94.98 & $12 / 6 / 95$ & 92.09 & 91.60 \\
\hline $12 / 16 / 87$ & 82.70 & 82.54 & $8 / 13 / 90$ & 83.33 & 83.14 & $4 / 10 / 93$ & 95.46 & 94.86 & $12 / 7 / 95$ & 92.91 & 92.39 \\
\hline \begin{tabular}{|l}
$12 / 17 / 87$ \\
\end{tabular} & 83.84 & 83.64 & $8 / 14 / 90$ & 85.45 & 85.19 & $4 / 11 / 93$ & 95.41 & 94.81 & $12 / 8 / 95$ & 93.44 & 92.91 \\
\hline $12 / 18 / 87$ & 84.49 & 84.26 & $8 / 15 / 90$ & 86.31 & 86.02 & $4 / 12 / 93$ & 95.44 & 94.84 & $12 / 9 / 95$ & 93.70 & 93.16 \\
\hline $\mid 12 / 19 / 87$ & 85.14 & 84.89 & $8 / 1690$ & 86.36 & 86.07 & $4 / 13 / 93$ & 95.42 & 94.82 & $12 / 10 / 95$ & 92.62 & 92.11 \\
\hline $12 / 20 / 87$ & 83.40 & 83.21 & $8 / 17 / 90$ & 86.01 & 85.73 & $4 / 14 / 93$ & 95.34 & 94.74 & $12 / 11 / 95$ & 90.38 & 89.95 \\
\hline $12 / 21 / 87$ & 82.30 & 82.15 & $8 / 18 / 90$ & 86.18 & 83.90 & $4 / 15 / 93$ & 95.22 & 94.62 & $12 / 12 / 95$ & 90.99 & 90.54 \\
\hline
\end{tabular}


Appendix $\mathrm{C}$ (continued)

SR-TNX Estimated Historic Daily Mean Elevation

\begin{tabular}{|c|c|c|c|c|c|c|c|c|c|c|c|}
\hline Date & $\begin{array}{c}\text { SR- } \\
\text { Jackson } \\
\text { Elevation } \\
\text { (ft-msl) }\end{array}$ & $\begin{array}{c}\text { SR-TNX } \\
\text { Estimated } \\
\text { Elevation } \\
\text { (ft-msl) } \\
\end{array}$ & Date & $\begin{array}{c}\text { SR- } \\
\text { Jackson } \\
\text { Elevation } \\
\text { (ft-msl) }\end{array}$ & $\begin{array}{c}\text { SR-TNX } \\
\text { Estimated } \\
\text { Elevation } \\
\text { (ft-msl) }\end{array}$ & Date & $\begin{array}{c}\text { SR- } \\
\text { Jackson } \\
\text { Elevation } \\
\text { (ft-msi) }\end{array}$ & $\begin{array}{c}\text { SR-TNX } \\
\text { Estimated } \\
\text { Elevation } \\
\text { (ft-msl) }\end{array}$ & Date & $\begin{array}{c}\text { SR- } \\
\text { Jackson } \\
\text { Elevation } \\
\text { (ft-msl) }\end{array}$ & \begin{tabular}{|c||} 
SR-TNX \\
Estimated \\
Elevation \\
(ft-msi)
\end{tabular} \\
\hline $12 / 22 / 87$ & 82.03 & 81.89 & $8 / 19 / 90$ & 84.04 & 83.83 & $4 / 16 \sqrt{93}$ & 95.18 & 94.59 & $12 / 13 / 95$ & 91.90 & 91.42 \\
\hline $12 / 23 / 87$ & 82.38 & 82.23 & $8 / 20 / 90$ & 83.92 & 83.71 & $4 / 17 / 93$ & 95.10 & 94.51 & $12 / 14 / 95$ & 92.21 & 91.72 \\
\hline $12 / 24 / 87$ & 82.90 & 82.73 & $8 / 21 / 90$ & 85.78 & 85.51 & $4 / 18 / 93$ & 94.21 & 93.65 & $12 / 15 / 95$ & 92.36 & 91.86 \\
\hline $12 / 25 / 87$ & 83.15 & 82.97 & $8 / 22 / 90$ & 86.65 & 86.35 & $4 / 19 / 93$ & 92.46 & 91.96 & $12 / 16 / 95$ & 92.19 & 91.70 \\
\hline $12 / 26 / 87$ & 83.35 & 83.16 & $8 / 23 / 90$ & 87.98 & 87.63 & $4 / 20 / 93$ & 91.40 & 90.94 & $12 / 17 / 95$ & 90.49 & 90.06 \\
\hline $12 / 27 / 87$ & 83.37 & 83.18 & $8 / 24 / 90$ & 87.71 & 87.37 & $4 / 21 / 93$ & 90.46 & 90.03 & $12 / 18 / 95$ & 87.91 & 87.57 \\
\hline $12 / 28 / 87$ & 82.80 & 82.63 & $8 / 25 / 90$ & 86.57 & 86.27 & $4 / 22193$ & 89.67 & 89.27 & $12 / 19 / 95$ & 88.29 & 87.93 \\
\hline $12 / 29 / 87$ & 82.57 & 82.41 & $8 / 26 / 90$ & 84.32 & 84.10 & $4 / 23 / 93$ & 89.84 & 89.43 & $12 / 20 / 95$ & 89.52 & 89.12 \\
\hline $12 / 30 / 87$ & 83.32 & 83.13 & $8 / 27 / 90$ & 84.09 & 83.88 & $4 / 24 / 93$ & 89.20 & 88.81 & $12 / 21 / 95$ & 90.51 & 90.08 \\
\hline $12 / 31 / 87$ & 83.75 & 83.55 & $8 / 28 / 90$ & 87.34 & 87.02 & $4 / 25 / 93$ & 87.66 & 87.33 & $12 / 22 / 95$ & 89.72 & 89.31 \\
\hline $1 / 1 / 88$ & 83.72 & 83.52 & $8 / 29 / 90$ & 89.94 & 89.53 & $4 / 26 / 93$ & 88.39 & 88.03 & $12 / 23 / 95$ & 88.46 & 88.10 \\
\hline $1 / 2 / 88$ & 83.31 & 83.13 & $8 / 30 / 90$ & 90.67 & 90.23 & $4 / 27 / 93$ & 89.68 & 89.28 & $12 / 24 / 95$ & 87.13 & 86.81 \\
\hline $1 / 3 / 88$ & 83.31 & 83.13 & $8 / 31 / 90$ & 90.99 & 90.54 & $4 / 28 / 93$ & 89.96 & 89.55 & $12 / 25 / 95$ & 86.53 & 86.23 \\
\hline $1 / 4 / 88$ & 83.20 & 83.02 & 9/1/90 & 90.94 & 90.49 & $4 / 29 / 93$ & 87.69 & 87.35 & $12 / 26 / 95$ & 86.29 & 86.00 \\
\hline 1/5/88 & 83.28 & 83.10 & 9/2/90 & 88.18 & 87.83 & $4 / 30 / 93$ & 85.27 & 85.02 & $12 / 27 / 95$ & 87.57 & 87.24 \\
\hline $1 / 6 / 88$ & 84.00 & 83.79 & $9 / 3 / 90$ & 85.64 & 85.37 & $5 / 1 / 93$ & 84.78 & 84.54 & $12 / 28 / 95$ & 87.76 & 87.42 \\
\hline $1 / 7 / 88$ & 83.91 & 83.70 & $9 / 4 / 90$ & 85.97 & 85.69 & $5 / 2 / 93$ & 84.90 & 84.66 & $12 / 29 / 95$ & 87.69 & 87.3 \\
\hline $1 / 8 / 88$ & 83.64 & 83.44 & 9/5/90 & 86.06 & 85.78 & $5 / 3 / 93$ & 84.84 & 84.60 & $12 / 30 / 95$ & 87.72 & 87.38 \\
\hline $1 / 9 / 88$ & 83.53 & 83.34 & $9 / 6 / 90$ & 86.67 & 86.37 & $5 / 4 / 93$ & 86.57 & 86.27 & $12 / 31 / 95$ & 87.30 & 86.98 \\
\hline $1 / 10 / 88$ & 83.30 & 83.12 & $9 / 7 / 90$ & 89.11 & 88.72 & $5 / 5 / 93$ & 87.95 & 87.61 & $1 / 1 / 96$ & 86.12 & 85.8 \\
\hline $1 / 11 / 88$ & 83.01 & 82.84 & $9 / 8 / 90$ & 90.27 & 89.84 & $5 / 6 \times 3$ & 88.05 & 87.70 & $1 / 2 / 96$ & 86.38 & 86.09 \\
\hline $1 / 12 / 88$ & 83.51 & 83.32 & 9/9/90 & 87.71 & 87.37 & $5 / 7 / 93$ & 88.08 & 87.73 & $1 / 3 / 96$ & 87.79 & 87.45 \\
\hline $1 / 13 / 88$ & 83.58 & 83.39 & $9 / 10 / 90$ & 84.96 & 84.72 & $5 / 8 / 93$ & 88.63 & 88.26 & $1 / 4 / 96$ & 88.48 & 88.12 \\
\hline $1 / 14 / 88$ & 83.18 & 83.00 & $9 / 11 / 90$ & 83.77 & 83.57 & $5 / 9 / 93$ & 89.12 & 88.73 & $1 / 5 / 96$ & 88.35 & 87.99 \\
\hline $1 / 15 / 88$ & 83.16 & 82.98 & $9 / 12 / 90$ & 83.27 & 83.09 & $5 / 10 / 93$ & 89.12 & 88.73 & $1 / 6 / 96$ & 88.24 & 87.89 \\
\hline $1 / 16 / 88$ & 83.34 & 83.15 & $9 / 13 / 90$ & 83.09 & 82.91 & $5 / 11 / 93$ & 88.90 & 88.52 & $1 / 7 / 96$ & 87.06 & 86.75 \\
\hline $1 / 17 / 88$ & 83.01 & 82.84 & $9 / 14 / 90$ & 83.10 & 82.92 & $5 / 12 / 93$ & 88.36 & 88.00 & $1 / 8 / 96$ & 84.43 & 84.21 \\
\hline $1 / 18 / 88$ & 82.92 & 82.75 & $9 / 15 / 90$ & 83.55 & 83.36 & $5 / 13 / 93$ & 88.33 & 87.97 & $1 / 9 / 96$ & 87.78 & 87.44 \\
\hline $1 / 19 / 88$ & 83.45 & 83.26 & $9 / 16 / 90$ & 83.84 & 83.64 & $5 / 14 / 93$ & 88.80 & 88.43 & $1 / 10 / 96$ & 88.60 & 88.23 \\
\hline $1 / 20 / 88$ & 83.88 & 83.68 & $9 / 17 / 90$ & 83.19 & 83.01 & $5 / 15 / 93$ & 88.34 & 87.98 & $1 / 11 / 96$ & 87.07 & 86.76 \\
\hline $1 / 21 / 88$ & 84.35 & 84.13 & $9 / 18 / 90$ & 82.89 & 82.72 & $5 / 16 / 93$ & 86.95 & 86.64 & $1 / 12 / 96$ & 85.83 & 85.56 \\
\hline $1 / 22 / 88$ & 84.42 & 84.20 & $9 / 19 / 90$ & 82.86 & 82.69 & $5 / 17 / 93$ & 86.43 & 86.14 & $1 / 13 / 96$ & 85.85 & 85.58 \\
\hline $1 / 23 / 88$ & 84.32 & 84.10 & $9 / 20190$ & 82.84 & 82.67 & $5 / 18 / 93$ & 87.04 & 86.73 & $1 / 14 / 96$ & 85.39 & 85.13 \\
\hline $1 / 24 / 88$ & 83.37 & 83.18 & $9 / 21 / 90$ & 83.34 & 83.15 & $5 / 19193$ & 87.80 & 87.46 & $1 / 15 / 96$ & 86.23 & 85.94 \\
\hline $1 / 25 / 88$ & 82.83 & 82.66 & $9 / 22 / 90$ & 84.89 & 84.65 & $5 / 20 / 93$ & 88.51 & 88.15 & $1 / 16 / 96$ & 84.40 & 84.18 \\
\hline $1 / 26 / 88$ & 82.69 & 82.53 & $9 / 23 / 90$ & 83.21 & 83.03 & $5 / 21 / 93$ & 88.19 & 87.84 & $1 / 17 / 96$ & 84.87 & 84.63 \\
\hline $1 / 27 / 88$ & 82.97 & 82.80 & $9 / 24 / 90$ & & & $5 / 22 / 93$ & 86.89 & 86.58 & $1 / 18 / 96$ & 84.93 & 84.69 \\
\hline $1 / 28 / 88$ & 83.15 & 82.97 & $9 / 25 / 90$ & & & $5 / 23 / 93$ & 85.95 & 85.67 & $1 / 19 / 96$ & 83.67 & 83.47 \\
\hline $1 / 29 / 88$ & 83.32 & 83.13 & $9 / 26 / 90$ & & & $5 / 24 / 93$ & 85.86 & 85.59 & $1 / 20 / 96$ & 85.07 & 84.82 \\
\hline $1 / 30 / 88$ & 83.73 & 83.53 & $9 / 27 / 90$ & & & $5 / 25 / 93$ & 87.55 & 87.22 & $1 / 21 / 96$ & 86.77 & 86.47 \\
\hline $1 / 31 / 88$ & 83.45 & 83.26 & $9 / 28 / 90$ & & & $5 / 26 / 93$ & 87.67 & 87.33 & $1 / 22196$ & 86.47 & 86.18 \\
\hline $2 / 1 / 88$ & 82.91 & 82.74 & $9 / 29 / 90$ & & & $5 / 27 / 93$ & 87.28 & 86.96 & $1 / 23 / 96$ & 85.19 & 84.94 \\
\hline $2 / 2 / 88$ & 82.89 & 82.72 & $9 / 30 / 90$ & & & $5 / 28 / 93$ & 87.62 & 87.29 & $1 / 24 / 96$ & 85.74 & 85.47 \\
\hline
\end{tabular}


Appendix C (continued)

SR-TNX Estimated Historic Daily Mean Elevation

\begin{tabular}{|c|c|c|c|c|c|c|c|c|c|c|c|}
\hline Date & $\begin{array}{c}\mathrm{SR}- \\
\text { Jackson } \\
\text { Elevation } \\
\text { (ft-msl) }\end{array}$ & $\begin{array}{c}\text { SR-TNX } \\
\text { Estimated } \\
\text { Elevation } \\
\text { (ft-msl) }\end{array}$ & Date & $\begin{array}{c}\text { SR. } \\
\text { Jackson } \\
\text { Elevation } \\
\text { (ft-msl) }\end{array}$ & $\begin{array}{c}\text { SR-TNX } \\
\text { Estimated } \\
\text { Elevation } \\
\text { (ft-msi) }\end{array}$ & Date & $\begin{array}{c}\text { SR- } \\
\text { Jackson } \\
\text { Elevation } \\
\text { (ft-msl) } \\
\end{array}$ & $\begin{array}{c}\text { SR-TNX } \\
\text { Estimated } \\
\text { Elevation } \\
\text { (ft-msl) }\end{array}$ & Date & $\begin{array}{c}\text { SR- } \\
\text { Jackson } \\
\text { Elevation } \\
\text { (ft-msl) }\end{array}$ & \begin{tabular}{c|} 
SR-TNX \\
Estimated \\
Elevation \\
(ft-msl)
\end{tabular} \\
\hline $2 / 3 / 88$ & 82.90 & 82.73 & $10 / 1 / 90$ & 82.77 & 82.60 & $5 / 29 / 93$ & 86.95 & 86.64 & $1 / 25 / 96$ & 85.40 & 85.14 \\
\hline $2 / 4 / 88$ & 83.26 & 83.08 & $10 / 2 / 90$ & 82.60 & 82.44 & $5 / 30 / 93$ & 85.64 & 85.37 & $1 / 26 / 96$ & 86.35 & 86.06 \\
\hline $2 / 5 / 88$ & 85.88 & 85.61 & $10 / 3 / 90$ & 83.03 & 82.85 & $5 / 31 / 93$ & 85.48 & 85.22 & $1 / 27 / 96$ & 86.86 & $\overline{86.55}$ \\
\hline $2 / 6 / 88$ & 88.89 & 88.51 & $10 / 4 / 90$ & 83.57 & 83.38 & $6 / 1 / 93$ & 86.33 & 86.04 & $1 / 28 / 96$ & 87.07 & 86.76 \\
\hline $2 / 7 / 88$ & 85.74 & 85.47 & $10 / 5 / 90$ & 83.39 & 83.20 & $6 / 2 / 93$ & 87.37 & 87.05 & $1 / 29 / 96$ & 90.06 & 89.64 \\
\hline $2 / 8 / 88$ & 83.76 & 83.56 & $10 / 6 / 90$ & 82.63 & 82.47 & $6 / 3 / 93$ & 86.63 & 86.33 & $1 / 30 / 96$ & 90.99 & 90.54 \\
\hline $2 / 9 / 88$ & 82.71 & 82.55 & $10 / 7 / 90$ & 82.30 & 82.15 & $6 / 4 / 93$ & 85.91 & 85.64 & $1 / 31 / 96$ & 92.31 & 91.81 \\
\hline $2 / 10 / 88$ & 82.77 & 82.60 & $10 / 8 / 90$ & 82.31 & 82.16 & $6 / 5 / 93$ & 86.06 & 85.78 & $2 / 1 / 96$ & 93.03 & 92.51 \\
\hline $2 / 11 / 88$ & 83.28 & 83.10 & $10 / 9 / 90$ & 83.14 & 82.96 & $6 / 6 / 93$ & 85.46 & 85.20 & $2 / 2 / 96$ & 93.68 & 93.14 \\
\hline $2 / 12 / 88$ & 83.00 & 82.83 & $10 / 10 / 90$ & 84.43 & 84.21 & $6 / 793$ & 85.11 & 84.86 & $2 / 3 / 96$ & 94.06 & 93.50 \\
\hline $2 / 13 / 88$ & 83.97 & 83.76 & $10 / 11 / 90$ & 85.27 & 85.02 & $6 / 8 / 93$ & 85.55 & 85.29 & $2 / 4 / 96$ & 93.98 & 93.43 \\
\hline $2 / 14 / 88$ & 83.32 & 83.13 & $10 / 12 / 90$ & 88.85 & 88.47 & $6 / 9 / 93$ & 86.97 & 86.66 & $2 / 5 / 96$ & 93.88 & 93.33 \\
\hline $2 / 15 / 88$ & 82.25 & 82.10 & $10 / 13 / 90$ & 94.22 & 93.66 & $6 / 10 / 93$ & 88.35 & 87.99 & $2 / 6 / 96$ & 94.67 & 94.09 \\
\hline $2 / 16 / 88$ & 82.19 & 82.04 & $10 / 14 / 90$ & 96.76 & 96.11 & $6 / 11 / 93$ & 88.33 & 87.97 & $2 / 7 / 96$ & 95.08 & 94.49 \\
\hline $2 / 17 / 88$ & 82.61 & 82.45 & $10 / 15 / 90$ & 96.56 & 95.92 & $6 / 12 / 93$ & 86.55 & 86.25 & $2 / 8 / 96$ & \begin{tabular}{l|l}
95.13 \\
\end{tabular} & 94.54 \\
\hline $2 / 18 / 88$ & 83.09 & 82.91 & $10 / 16 / 90$ & 94.69 & 94.11 & $6 / 13 / 93$ & 86.27 & 85.98 & $2 / 9 / 96$ & 95.13 & 94.54 \\
\hline $2 / 19 / 88$ & 83.83 & 83.63 & $10 / 17 / 90$ & 91.97 & 91.49 & $6 / 14 / 93$ & 85.69 & 85.42 & $2 / 10 / 96$ & 95.12 & 94.53 \\
\hline $2 / 20 / 88$ & 84.18 & 83.97 & $10 / 18 / 90$ & 89.69 & 89.28 & $6 / 15 / 93$ & 84.81 & 84.57 & $2 / 11 / 96$ & 95.12 & 94.53 \\
\hline $2 / 21 / 88$ & 83.56 & 83.37 & $10 / 19 / 90$ & 87.09 & 86.77 & $6 / 16 / 93$ & 84.74 & 84.51 & $2 / 12 / 96$ & 95.12 & 94.53 \\
\hline $2 / 22 / 88$ & 83.04 & 82.86 & $10 / 20 / 90$ & 84.46 & 84.24 & $6 / 17 / 93$ & 85.61 & 85.35 & $2 / 13 / 96$ & 95.15 & 94.56 \\
\hline $2 / 23 / 88$ & 82.80 & 82.63 & $10 / 21 / 90$ & 83.59 & 83.40 & $6 / 18 / 93$ & 87.39 & 87.06 & $2 / 14 / 96$ & 95.16 & 94.57 \\
\hline $2 / 24 / 88$ & 82.84 & 82.67 & $10 / 22 / 90$ & 84.23 & 84.01 & $6 / 19 / 93$ & 87.23 & 86.91 & $2 / 15 / 96$ & 95.17 & 94.58 \\
\hline $2 / 25 / 88$ & 82.79 & 82.62 & $10 / 23 / 90$ & 88.65 & 88.28 & $6 / 20 / 93$ & 85.50 & 85.24 & $2 / 16 / 96$ & 95.06 & 94.47 \\
\hline $2 / 26 / 88$ & 82.73 & 82.57 & $10 / 24 / 90$ & 91.86 & 91.38 & $6 / 21 / 93$ & 84.84 & 84.60 & $2 / 17 / 96$ & 94.84 & 94.26 \\
\hline $2 / 27 / 88$ & 82.65 & 82.49 & $10 / 25 / 90$ & 93.14 & 92.62 & $6 / 22193$ & 86.30 & 86.01 & $2 / 18 / 96$ & & \\
\hline $2 / 28 / 88$ & 82.55 & 82.39 & $10 / 26 / 90$ & 92.43 & 91.93 & $6 / 23 / 93$ & 87.13 & 86.81 & $2 / 19 / 96$ & & \\
\hline $2 / 29 / 88$ & 82.30 & 82.15 & $10 / 27 / 90$ & 89.07 & 88.69 & $6 / 24 / 93$ & 87.19 & 86.87 & $2 / 20 / 96$ & 94.20 & 93.64 \\
\hline $3 / 1 / 88$ & 82.34 & 82.19 & $10 / 28 / 90$ & 85.67 & 85.40 & $6 / 25 / 93$ & 87.22 & 86.90 & $2 / 21 / 96$ & 94.17 & 93.61 \\
\hline $3 / 2 / 88$ & 82.66 & 82.50 & $10 / 29 / 90$ & 84.81 & 84.57 & $6 / 26 / 93$ & 87.10 & 86.78 & $2 / 22 / 96$ & 94.18 & 93.62 \\
\hline $3 / 3 / 88$ & 82.71 & 82.55 & $10 / 30 / 90$ & 86.91 & 86.60 & $6 / 27 / 93$ & 85.76 & 85.49 & $2 / 23196$ & 94.21 & 93.65 \\
\hline 3/4/88 & 82.60 & 82.44 & $10 / 31 / 90$ & 87.44 & 87.11 & $6 / 28 / 93$ & 84.68 & 84.45 & $2 / 24 / 96$ & 94.18 & 93.62 \\
\hline $3 / 5 / 88$ & 82.68 & 82.52 & $11 / 1 / 90$ & 86.98 & 86.67 & $6 / 29 / 93$ & 84.85 & 84.61 & $2 / 25 / 96$ & 93.09 & 92.57 \\
\hline $3 / 6 / 88$ & 82.72 & 82.56 & $11 / 2 / 90$ & 86.65 & 86.35 & $6 / 30 / 93$ & 85.45 & 85.19 & $2 / 26 / 96$ & 90.51 & 90.08 \\
\hline $3 / 7 / 88$ & 82.44 & 82.29 & $11 / 3 / 90$ & 85.33 & 85.08 & $7 / 1 / 93$ & 84.81 & 84.57 & $2 / 27 / 96$ & 91.06 & 90.61 \\
\hline$=3 / 8 / 88$ & $=82.35$ & 82.20 & $=11 / 4 / 90$ & 83.84 & 83.64 & $7 / 2 / 93$ & 85.50 & 85.24 & $2 / 28 / 96$ & 92.01 & 91.52 \\
\hline $3 / 9 / 88$ & 83.32 & 83.13 & $11 / 5 / 90$ & 84.48 & 84.25 & $7 / 3 / 93$ & 85.03 & 84.79 & $2 / 29 / 96$ & 92.46 & 91.96 \\
\hline $3 / 10 / 88$ & 84.05 & 83.84 & $11 / 6 / 90$ & 85.66 & 85.39 & $7 / 4 / 93$ & 84.93 & 84.69 & $3 / 1196$ & 92.73 & 92.22 \\
\hline $3 / 11 / 88$ & 84.20 & 83.98 & $11 / 7 / 90$ & 85.91 & 85.64 & $7 / 5 / 93$ & 84.18 & 83.97 & $3 / 2 / 96$ & 92.77 & 92.26 \\
\hline $3 / 12 / 88$ & 84.42 & 84.20 & $11 / 8 / 90$ & 86.03 & 85.75 & $7 / 6 / 93$ & 84.26 & 84.04 & $3 / 3 / 96$ & 91.र्मी & 90.97 \\
\hline $3 / 13 / 88$ & 83.39 & 83.20 & II/9/90 & 85.49 & 85.23 & $7 / 7 / 93$ & 86.04 & 85.76 & $3 / 4 / 96$ & 88.38 & 88.02 \\
\hline $3 / 14 / 88$ & 82.93 & 82.76 & $11 / 10 / 90$ & 85.34 & 85.09 & $7 / 8 / 93$ & 87.20 & 86.88 & $3 / 5 / 96$ & 88.18 & 87.83 \\
\hline $3 / 15 / 88$ & 82.74 & 82.57 & $11 / 11 / 90$ & 86.79 & 86.49 & $7 / 9 / 93$ & 85.83 & 85.56 & $3 / 6 / 96$ & 88.57 & 88.20 \\
\hline $3 / 16 / 88$ & 83.74 & 83.54 & $11 / 12 / 90$ & 87.34 & 87.02 & $7 / 10 / 93$ & 84.21 & 83.99 & $3 / 7 / 96$ & 89.74 & 89.33 \\
\hline
\end{tabular}


Appendix C (continued)

SR-TNX Estimated Historic Daily Mean Elevation

\begin{tabular}{|c|c|c|c|c|c|c|c|c|c|c|c|}
\hline Date & $\begin{array}{c}\text { SR- } \\
\text { Jackson } \\
\text { Elevation } \\
\text { (ft-msl) }\end{array}$ & $\begin{array}{c}\text { SR-TNX } \\
\text { Estimated } \\
\text { Elevation } \\
\text { (ft-msl) }\end{array}$ & Date & \begin{tabular}{|c|} 
SR- \\
Jackson \\
Elevation \\
(ft-msl)
\end{tabular} & $\begin{array}{c}\text { SR-TNX } \\
\text { Estimated } \\
\text { Elevation } \\
\text { (ft-msl) }\end{array}$ & Date & $\begin{array}{c}\text { SR- } \\
\text { Jackson } \\
\text { Eicvation } \\
\text { (ft-msl) }\end{array}$ & $\begin{array}{l}\text { SR-TNX } \\
\text { Estimated } \\
\text { Elevation } \\
\text { (ft-msl) }\end{array}$ & Date & $\begin{array}{c}\text { SR- } \\
\text { Jackson } \\
\text { Elevation } \\
\text { (ft-msl) }\end{array}$ & \begin{tabular}{c|} 
SR-TNX \\
Estimated \\
Elevation \\
(ft-msl)
\end{tabular} \\
\hline $3 / 17 / 88$ & 83.81 & 83.61 & $11 / 13 / 90$ & 85.78 & 85.51 & $7 / 11 / 93$ & 83.23 & 83.05 & $3 / 8 / 96$ & 92.69 & 92.18 \\
\hline $3 / 18 / 88$ & 82.98 & 82.81 & $11 / 14 / 90$ & 85.04 & 84.80 & $7 / 12 / 93$ & 83.30 & 83.12 & $3 / 9196$ & 94.60 & 94.03 \\
\hline $3 / 19 / 88$ & 82.95 & 82.78 & $11 / 15 / 90$ & 85.35 & 85.09 & $7 / 13 / 93$ & 85.01 & 84.77 & $3 / 10 / 96$ & 95.37 & 94.77 \\
\hline $3 / 20 / 88$ & 82.50 & 82.34 & $11 / 16 / 90$ & 85.00 & 84.76 & $7 / 14 / 93$ & 84.98 & 84.74 & $3 / 11 / 96$ & 95.54 & 94.93 \\
\hline $3 / 21 / 88$ & 82.39 & 82.24 & $11 / 17 / 90$ & 83.26 & 83.08 & $7 / 15 / 93$ & 84.81 & 84.57 & $3 / 12 / 96$ & 95.59 & 94.98 \\
\hline $3 / 22 / 88$ & 82.44 & 82.29 & $11 / 18 / 90$ & 83.28 & 83.10 & $7 / 16 / 93$ & 84.25 & 84.03 & $3 / 13 / 96$ & 95.60 & 94.99 \\
\hline $3 / 23 / 88$ & 82.91 & 82.74 & $11 / 19 / 90$ & & & $7 / 17 / 93$ & 84.08 & 83.87 & $3 / 14 / 96$ & 95.58 & 94.97 \\
\hline $3 / 24 / 88$ & 83.33 & 83.14 & $11 / 20 / 90$ & & & $7 / 18 / 93$ & 83.82 & 83.62 & $3 / 15 / 96$ & 95.70 & 95.09 \\
\hline $3 / 25 / 88$ & 83.24 & 83.06 & $11 / 21 / 90$ & 83.70 & 83.50 & $7 / 19 / 93$ & 84.08 & 83.87 & $3 / 16196$ & 95.83 & 95.21 \\
\hline $3 / 26 / 88$ & 82.93 & 82.76 & $11 / 22 / 90$ & 83.19 & 83.01 & $7 / 20 / 93$ & 86.87 & 86.56 & $3 / 17 / 96$ & 95.71 & 95.10 \\
\hline $3 / 27 / 88$ & 82.87 & 82.70 & $11 / 23 / 90$ & 83.99 & 83.78 & $7 / 21 / 93$ & 87.62 & 87.29 & $3 / 18 / 96$ & 95.47 & 94.87 \\
\hline $3 / 28 / 88$ & 82.84 & 82.67 & $11 / 24 / 90$ & 83.57 & 83.38 & $7 / 22 / 93$ & 86.80 & 86.49 & $3 / 19 / 96$ & 95.32 & 94.72 \\
\hline $3 / 29 / 88$ & 82.60 & 82.44 & $11 / 25 / 90$ & 83.15 & 82.97 & $7 / 23 / 93$ & 86.81 & 86.50 & $3 / 20 / 96$ & 95.25 & 94.65 \\
\hline $3 / 30 / 88$ & 82.40 & 82.25 & $11 / 26 / 90$ & 83.02 & 82.85 & $7 / 24 / 93$ & 85.18 & 84.93 & $3 / 21 / 96$ & 95.26 & 94.66 \\
\hline $3 / 31 / 88$ & 82.45 & 82.29 & $11 / 27 / 90$ & 84.86 & 84.62 & $7 / 25 / 93$ & 85.11 & 84.86 & $3 / 22 / 96$ & 95.47 & 94.87 \\
\hline $4 / 1 / 88$ & 82.43 & 82.28 & $11 / 28 / 90$ & 84.30 & 84.08 & $7 / 26 / 93$ & 84.74 & 84.51 & $3 / 23 / 96$ & 95.65 & 95.04 \\
\hline $4 / 2 / 88$ & 82.68 & 82.52 & $11 / 29 / 90$ & 83.10 & 82.92 & $7 / 27 / 93$ & 84.25 & 84.03 & $3 / 24 / 96$ & 95.70 & 95.09 \\
\hline $4 / 3 / 88$ & 82.53 & \begin{tabular}{l|l|}
82.37 \\
\end{tabular} & $11 / 30 / 90$ & 83.66 & 83.46 & $7 / 28 / 93$ & 84.80 & 84.56 & $3 / 25 / 96$ & 95.73 & 95.12 \\
\hline $4 / 4 / 88$ & 82.14 & 82.00 & $12 / 1 / 90$ & 84.35 & 84.13 & $7 / 29 / 93$ & 84.88 & 84.64 & $3 / 26 / 96$ & 95.74 & 95.13 \\
\hline $4 / 5 / 88$ & 82.31 & 82.16 & $12 / 2 / 90$ & 83.22 & 83.04 & $7 / 30 / 93$ & 85.85 & 85.58 & $3 / 27 / 96$ & 95.73 & 95.12 \\
\hline $4 / 6 / 88$ & 82.45 & 82.29 & $12 / 3 / 90$ & 83.59 & 83.40 & $7 / 31 / 93$ & 84.21 & 83.99 & $3 / 28 / 96$ & 95.42 & 94.82 \\
\hline $4 / 7 / 88$ & 82.33 & 82.18 & $12 / 4 / 90$ & 85.52 & 85.26 & $8 / 1 / 93$ & 83.66 & 83.46 & $3 / 29 / 96$ & 94.98 & 94.39 \\
\hline $4 / 8 / 88$ & 82.23 & 82.08 & $12 / 5 / 90$ & 86.56 & 86.26 & $8 / 2 / 93$ & 83.58 & 83.39 & $3 / 30 / 96$ & 94.74 & 94.16 \\
\hline $4 / 9 / 88$ & 82.24 & 82.09 & $12 / 6 / 90$ & 86.50 & 86.21 & $8 / 3 / 93$ & 85.50 & 85.24 & $3 / 31 / 96$ & 93.56 & 93.02 \\
\hline $4 / 10 / 88$ & 81.88 & 81.74 & $12 / 7 / 90$ & 86.75 & 86.45 & $8 / 4 / 93$ & 86.37 & 86.08 & $4 / 1 / 96$ & 91.04 & 90.59 \\
\hline $4 / 11 / 88$ & 82.06 & 81.92 & $12 / 8 / 90$ & 85.48 & 85.22 & $8 / 5 / 93$ & 86.48 & 86.19 & $4 / 2 / 96$ & 90.54 & 90.11 \\
\hline $4 / 12 / 88$ & 82.48 & 82.32 & $12 / 9 / 90$ & 83.65 & 83.45 & $8 / 6 / 93$ & 86.46 & 86.17 & $4 / 3 / 96$ & 91.62 & 91.15 \\
\hline $4 / 13 / 88$ & 83.27 & 83.09 & $12 / 10 / 90$ & 83.77 & 83.57 & $8 / 7 / 93$ & 86.35 & 86.06 & $4 / 4 / 96$ & 92.08 & 91.59 \\
\hline $4 / 14 / 88$ & 83.36 & 83.17 & $12 / 11 / 90$ & 86.53 & 86.23 & $8 / 8 / 93$ & 84.61 & 84.38 & $4 / 5 / 96$ & 92.05 & 91.56 \\
\hline $4 / 15 / 88$ & 82.80 & 82.63 & $12 / 12 / 90$ & 85.49 & 85.23 & $8 / 9 / 93$ & 83.93 & 83.72 & $4 / 6 / 96$ & 91.93 & 91.45 \\
\hline $4 / 16 / 88$ & 82.41 & 82.26 & $12 / 13 / 90$ & 83.30 & 83.12 & $8 / 10 / 93$ & 84.79 & 84.55 & $4 / 7 / 96$ & 90.53 & 90.10 \\
\hline $4 / 17 / 88$ & 81.95 & 81.81 & $12 / 14 / 90$ & 83.30 & 83.12 & $8 / 11 / 93$ & 84.72 & 84.49 & $4 / 8 \% 6$ & 88.17 & 87.82 \\
\hline $4 / 18 / 88$ & 81.88 & 81.74 & $12 / 15 / 90$ & 83.58 & 83.39 & $8 / 12 / 93$ & 85.59 & 85.33 & $4 / 9 / 96$ & 90.18 & 89.76 \\
\hline $4 / 19 / 88$ & 82.16 & 82.01 & $12 / 16 / 90$ & 83.17 & 82.99 & $8 / 13 / 93$ & 86.40 & 86.11 & $4 / 10 / 96$ & 91.72 & 91.24 \\
\hline $4 / 20 / 88$ & 82.34 & 82.19 & $12 / 17 / 90$ & 83.08 & 82.90 & $8 / 14 / 93$ & 85.28 & 85.03 & $4 / 11 / 96$ & 92.03 & 91.54 \\
\hline $4 / 21 / 88$ & 82.40 & 82.25 & $12 / 18 / 90$ & 85.43 & 85.17 & $8 / 15 / 93$ & 83.71 & 83.51 & $4 / 12 / 96$ & 92.16 & 91.67 \\
\hline $4 / 22 / 88$ & 82.53 & 82.37 & $12 / 19 / 90$ & 84.86 & 84.62 & $8 / 16 / 93$ & 83.36 & 83.17 & $4 / 13 / 96$ & 92.18 & 91.69 \\
\hline $4 / 23 / 88$ & 82.69 & 82.53 & $12 / 20 / 90$ & 84.23 & 84.01 & $8 / 17 / 93$ & 85.14 & 84.89 & $4 / 14 / 96$ & 90.73 & 90.29 \\
\hline $4 / 24 / 88$ & 83.24 & 83.06 & $12 / 21 / 90$ & 85.76 & 85.49 & $8 / 18 / 93$ & 86.02 & 85.74 & $4 / 15 / 96$ & 87.70 & 87.36 \\
\hline $4 / 25 / 88$ & 83.51 & 83.32 & $12 / 22 / 90$ & 84.85 & 84.61 & $8 / 19193$ & 85.91 & 85.64 & $4 / 16 / 96$ & 87.60 & 87.27 \\
\hline $4 / 26 / 88$ & 83.77 & 83.57 & $12 / 23 / 90$ & 84.17 & 83.96 & $8 / 20 / 93$ & 85.32 & 85.07 & $4 / 17 / 96$ & 87.89 & 87.55 \\
\hline $4 / 27 / 88$ & 84.34 & 84.12 & $12 / 24 / 90$ & 84.94 & 84.70 & $8 / 21 / 93$ & 84.10 & 83.89 & $4 / 18 / 96$ & 87.60 & 87.27 \\
\hline $4 / 28 / 88$ & 83.48 & 83.29 & $12 / 25 / 90$ & 85.96 & 85.68 & $8 / 22 / 93$ & 83.63 & 83.43 & $4 / 19 / 96$ & 87.13 & 86.81 \\
\hline
\end{tabular}


Appendix C (continued)

SR-TNX Estimated Historic Daily Mean Elevation

\begin{tabular}{|c|c|c|c|c|c|c|c|c|c|c|c|}
\hline Date & \begin{tabular}{|c|} 
SR- \\
Jackson \\
Elevation \\
(ti-msl) \\
\end{tabular} & \begin{tabular}{|l|} 
SR-TNX \\
Estimated \\
Elevation \\
(ft-msl)
\end{tabular} & Date & \begin{tabular}{|c|} 
SR- \\
Jackson \\
Elevation \\
(ft-msi) \\
\end{tabular} & \begin{tabular}{|c|} 
SR-TNX \\
Estimated \\
Elevation \\
(ft-msl) \\
\end{tabular} & Date & \begin{tabular}{|c|} 
SR- \\
Jackson \\
Elevation \\
(ft-msi) \\
\end{tabular} & \begin{tabular}{|c|} 
SR-TNX \\
Estimated \\
Elevation \\
(ft-msl) \\
\end{tabular} & Date & \begin{tabular}{|c|} 
SR- \\
Jackson \\
Elevation \\
(ft-msl)
\end{tabular} & \begin{tabular}{|c|} 
SR-TNX \\
Estimated \\
Elevation \\
(ft-msl)
\end{tabular} \\
\hline $4 / 29 / 88$ & 83.04 & 82.86 & $12 / 26 / 90$ & 85.99 & 85.71 & $8 / 23 / 93$ & 83.57 & 83.38 & $4 / 20 / 96$ & 86.58 & 86.28 \\
\hline $4 / 30 / 88$ & 82.63 & 82.47 & $12 / 27 / 90$ & 85.07 & 84.82 & $8 / 24 / 93$ & 83.71 & 83.51 & $4 / 21 / 96$ & 85.26 & 85.01 \\
\hline $5 / 1 / 88$ & $\begin{array}{l}82.38 \\
\end{array}$ & 82.23 & $12 / 28 / 90$ & 85.54 & 85.28 & $8 / 25 / 93$ & 84.61 & 84.38 & $4 / 22 / 96$ & 85.19 & 84.94 \\
\hline $5 / 2 / 88$ & 82.10 & 81.96 & $12 / 29 / 90$ & 84.91 & $\begin{array}{l}84.67 \\
\end{array}$ & $8 / 26 / 93$ & 85.75 & 85.48 & $4 / 23 / 96$ & 85.96 & 85.68 \\
\hline $5 / 3 / 88$ & \begin{tabular}{l|l}
82.08 \\
\end{tabular} & \begin{tabular}{|l|}
81.94 \\
\end{tabular} & $12 / 30 / 90$ & 84.05 & 83.84 & $8 / 27 / 93$ & 85.51 & 85.25 & $4 / 24 / 96$ & 86.55 & 86.25 \\
\hline $5 / 4 / 88$ & 82.06 & 81.92 & $12 / 31 / 90$ & 83.68 & 83.48 & $8 / 28 / 93$ & 83.96 & 83.75 & $4 / 25 / 96$ & 86.05 & 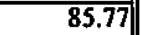 \\
\hline $5 / 5 / 88$ & \begin{tabular}{|c|}
82.03 \\
\end{tabular} & 81.89 & $1 / 1 / 91$ & 83.92 & 83.71 & $8 / 29 / 93$ & 83.56 & 83.37 & $4 / 26 / 96$ & 85.17 & 84.92 \\
\hline $5 / 6 / 88$ & 81.96 & 81.82 & $1 / 2 / 91$ & 83.68 & 83.48 & $8 / 30 / 93$ & 83.44 & 83.25 & $4 / 27 / 96$ & 84.72 & 84.49 \\
\hline $5 / 7 / 88$ & 81.90 & 81.76 & $1 / 3 / 91$ & 84.16 & 83.95 & $8 / 31 / 93$ & 83.83 & 83.63 & $4 / 28 / 96$ & 84.61 & $\overline{84.38}$ \\
\hline $5 / 8 / 88$ & 82.00 & $\begin{array}{l}81.86 \\
\end{array}$ & $1 / 4 / 91$ & 84.79 & 84.55 & $9 / 1 / 93$ & 84.21 & 83.99 & $4 / 29 / 96$ & \begin{tabular}{|l|l|}
84.69 \\
\end{tabular} & 84.46 \\
\hline $59 / 88$ & \begin{tabular}{|l|}
81.97 \\
\end{tabular} & 81.83 & $1 / 5 / 91$ & 84.56 & 84.33 & $9 / 2 / 93$ & 84.36 & 84.14 & $4 / 30 / 96$ & 86.85 & 86.54 \\
\hline $5 / 10 / 88$ & 81.89 & 81.75 & $1 / 6 / 91$ & 83.39 & 83.20 & $9 / 3 / 93$ & 84.24 & 84.02 & $5 / 1 / 96$ & 90.57 & 90.13 \\
\hline $5 / 11 / 88$ & 81.87 & 81.73 & $1 / 7 / 91$ & 83.36 & 83.17 & $9 / 4 / 93$ & 83.93 & 83.72 & $5 / 2 / 96$ & 92.95 & 92.43 \\
\hline $5 / 12 / 88$ & $\begin{array}{l}81.68 \\
\end{array}$ & 81.55 & $1 / 8 / 91$ & & & $9 / 5 / 93$ & 83.49 & 83.30 & $5 / 3 / 96$ & 92.63 & 92.12 \\
\hline $5 / 13 / 88$ & 81.61 & 81.48 & $1 / 9 / 91$ & & & $9 / 6 / 93$ & 83.62 & 83.42 & $5 / 4 / 96$ & 89.29 & 88.90 \\
\hline $5 / 14 / 88$ & \begin{tabular}{|l|l|}
81.59 \\
\end{tabular} & 81.46 & $1 / 10 / 91$ & & & $9 / 7 / 93$ & 83.76 & 83.56 & $5 / 5 / 96$ & 87.33 & 87.01 \\
\hline $5 / 15 / 88$ & 81.59 & 81.46 & $1 / 11 / 91$ & 83.73 & 83.53 & $9 / 8 / 93$ & 84.32 & 84.10 & $5 / 6 / 96$ & 88.09 & 87.74 \\
\hline $5 / 16 / 88$ & 81.64 & 81.51 & $1 / 12 / 91$ & 83.66 & 83.46 & $9 / 9 / 93$ & \begin{tabular}{|c|}
84.44 \\
\end{tabular} & 84.22 & $5 / 7 / 96$ & 91.12 & 90.67 \\
\hline $5 / 17 / 88$ & 81.55 & \begin{tabular}{|l|}
81.43 \\
\end{tabular} & $1 / 13 / 91$ & 86.88 & 86.57 & $9 / 10 / 93$ & 84.39 & 84.17 & $5 / 8 / 96$ & 89.56 & 89.16 \\
\hline$S / 18 / 88$ & \begin{tabular}{|c|}
81.57 \\
\end{tabular} & 81.45 & $\overline{1 / 14 / 91}$ & $\begin{array}{l}88.07 \\
\end{array}$ & 87.72 & $9 / 11 / 93$ & 83.21 & 83.03 & $5 / 9 / 96$ & 85.86 & 85.59 \\
\hline $5 / 19 / 88$ & \begin{tabular}{|l|}
81.58 \\
\end{tabular} & 81.45 & $1 / 15 / 91$ & 85.84 & 85.57 & $9 / 12 / 93$ & 82.89 & 82.72 & $5 / 10 / 96$ & 85.32 & 85.07 \\
\hline $5 / 20 / 88$ & 81.73 & 81.60 & $1 / 16 / 91$ & 84.28 & 84.06 & $9 / 13 / 93$ & 82.91 & 82.74 & $5 / 11 / 96$ & \begin{tabular}{l|l|}
84.22 \\
\end{tabular} & 84.00 \\
\hline $5 / 21 / 88$ & 81.81 & 81.68 & $1 / 17 / 91$ & 85.75 & 85.48 & $9 / 14 / 93$ & 83.68 & 83.48 & $5 / 12 / 96$ & 84.36 & 84.14 \\
\hline $5 / 22 / 88$ & 81.56 & 81.44 & $1 / 18 / 91$ & 87.25 & 86.93 & $9 / 15 / 93$ & 83.88 & 83.68 & $5 / 13 / 96$ & 84.18 & 83.97 \\
\hline $5 / 23 / 88$ & 81.511 & 81.39 & $\overline{1 / 19 / 91}$ & 84.98 & 84.74 & $9 / 16 / 93$ & 83.34 & 83.15 & $5 / 14 / 96$ & 83.88 & 83.68 \\
\hline $5 / 24 / 88$ & 81.66 & 81.53 & $1 / 20 / 91$ & 85.66 & 85.39 & $9 / 17 / 93$ & & & $5 / 15 / 96$ & 84.80 & 84.56 \\
\hline $5 / 25 / 88$ & \begin{tabular}{|l|}
81.87 \\
\end{tabular} & 81.73 & $1 / 21 / 91$ & 87.46 & 87.13 & $9 / 18 / 93$ & & & $5 / 16 / 96$ & 83.80 & 83.60 \\
\hline $5 / 26 / 88$ & 81.78 & 81.65 & $1 / 22 / 91$ & 87.96 & 87.61 & $9 / 19 / 93$ & & & $5 / 17 / 96$ & 83.29 & 83.11 \\
\hline $5 / 27 / 88$ & 81.65 & 81.52 & $1 / 23 / 91$ & 85.94 & 85.66 & $9 / 20 / 93$ & & & $5 / 18 / 96$ & 85.31 & 85.06 \\
\hline $5 / 28 / 88$ & 81.51 & 81.39 & $1 / 24 / 91$ & 85.20 & 84.95 & $9 / 21 / 93$ & & & $5 / 19 / 96$ & 87.04 & 86.73 \\
\hline $5 / 29 / 88$ & 81.45 & 81.33 & $1 / 25 / 91$ & 86.05 & 85.77 & $9 / 22 / 93$ & & & $5 / 20 / 96$ & 86.70 & 86.40 \\
\hline $5 / 30 / 88$ & 81.40 & 81.28 & $1 / 26 / 91$ & 88.13 & 87.78 & $9 / 23 / 93$ & & & $5 / 21 / 96$ & 86.62 & 86.32 \\
\hline $5 / 31 / 88$ & 81.49 & 81.37 & $1 / 27 / 91$ & 87.14 & 86.82 & $9 / 24 / 93$ & & & $5 / 22196$ & 86.07 & 85.75 \\
\hline $6 / 1 / 88$ & 81.41 & 81.29 & $1 / 28 / 91$ & 86.32 & 86.03 & $9 / 25 / 93$ & 83.24 & 83.06 & $5 / 23 / 96$ & 85.21 & 84.96 \\
\hline$=6 / 2 / 88$ & $=81: 48$ & $81: 36$ & $1 / 2991$ & 86.29 & 86.00 & $9 / 26193$ & 83.59 & 83.40 & $=5 / 24 / 96$ & 85.78 & 85.51 \\
\hline $6 / 3 / 88$ & 81.50 & 81.38 & $1 / 30 / 91$ & 86.48 & 86.19 & $9 / 27 / 93$ & 83.06 & 82.88 & $5 / 25 / 96$ & 86.37 & 86.08 \\
\hline $6 / 4 / 88$ & 81.46 & 81.34 & $1 / 31 / 91$ & 90.03 & 89.61 & $9 / 28 / 93$ & 83.03 & 82.85 & $5 / 26 / 96$ & 85.84 & 85.57 \\
\hline $6 / 5 / 88$ & \begin{tabular}{|l|}
81.42 \\
\end{tabular} & 81.30 & $2 / 1 / 91$ & 92.20 & 91.71 & $9 / 29 / 93$ & 83.41 & 83.22 & $5 / 27 / 96$ & $84 . \overline{5}$ & 84.32 \\
\hline $6 / 6 / 88$ & 81.34 & 81.22 & $2 / 2 / 91$ & 92.22 & 91.73 & $9 / 30 / 93$ & 83.02 & 82.85 & $5 / 28 / 96$ & 85.28 & 85.03 \\
\hline $6 / 7 / 88$ & 81.26 & 81.15 & $2 / 3 / 91$ & 89.52 & 89.12 & $10 / 1 / 93$ & $82 . \overline{94}$ & 82.77 & $5 / 29196$ & 88.49 & 88.13 \\
\hline $6 / 8 / 88$ & 81.24 & \begin{tabular}{|l|l|}
81.13 \\
\end{tabular} & $2 / 4 / 9 !$ & $\begin{array}{l}87.51 \\
\end{array}$ & 87.18 & $10 / 2 / 93$ & $82 . \overline{85}$ & 82.68 & $5 / 30 / 96$ & 90.84 & 90.40 \\
\hline $6 / 9 / 88$ & 81.54 & 81.42 & $2 / 5 / 91$ & 87.74 & 87.40 & $10 / 3 / 93$ & 83.03 & 82.85 & $5 / 31 / 96$ & 90.16 & 89.7 \\
\hline $6 / 10 / 88$ & 82.08 & 81.94 & $2 / 6 / 91$ & 86.79 & 86.49 & $10 / 4 / 93$ & $83 . \overline{02}$ & 82.85 & $6 / 1196$ & 89.52 & 89.12 \\
\hline
\end{tabular}


Appendix C (continued)

$\underline{\text { SR-TNX Estimated Historic Daily Mean Elevation }}$

\begin{tabular}{|c|c|c|c|c|c|c|c|c|c|c|c|}
\hline Date & $\begin{array}{c}\text { SR- } \\
\text { Jackson } \\
\text { Elevation } \\
\text { (ft-msl) }\end{array}$ & $\begin{array}{c}\text { SR-TNX } \\
\text { Estimated } \\
\text { Elevation } \\
\text { (ft-msl) }\end{array}$ & Date & $\begin{array}{c}\text { SR- } \\
\text { Jackson } \\
\text { Elevation } \\
\text { (ft-msi) }\end{array}$ & $\begin{array}{l}\text { SR-TNX } \\
\text { Estimated } \\
\text { Elevation } \\
\text { (ft-msl) }\end{array}$ & Date & \begin{tabular}{|c|} 
SR- \\
Jackson \\
Elevation \\
(ft-msl) \\
\end{tabular} & $\begin{array}{c}\text { SR-TNX } \\
\text { Estimated } \\
\text { Elevation } \\
\text { (ft-msl) }\end{array}$ & Date & $\begin{array}{c}\text { SR- } \\
\text { Jackson } \\
\text { Elevation } \\
\text { (f-msl) }\end{array}$ & $\begin{array}{c}\text { SR-TNX } \\
\text { Estimated } \\
\text { Elevation } \\
(\mathrm{ft}-\mathrm{msl})\end{array}$ \\
\hline $6 / 11 / 88$ & 82.64 & 82.48 & $2 / 7 / 91$ & & & $10 / 5 / 93$ & 84.40 & 84.18 & $6 / 2 / 96$ & 87.48 & 87.15 \\
\hline $6 / 12 / 88$ & 82.37 & 82.22 & 2/8/91 & & & $10 / 6 / 93$ & 84.84 & 84.60 & $6 / 3 / 96$ & 85.55 & 85.29 \\
\hline $6 / 13 / 88$ & 81.75 & 81.62 & $2 / 9 / 91$ & & & $10 / 7 / 93$ & 83.74 & 83.54 & $6 / 4 / 96$ & 86.22 & 85.93 \\
\hline $6 / 14 / 88$ & 81.45 & 81.33 & $2 / 10 / 91$ & & & $10 / 8 / 93$ & 82.94 & 82.77 & $6 / 5 / 96$ & 87.56 & 87.23 \\
\hline $6 / 15 / 88$ & 81.19 & 81.08 & $2 / 11 / 91$ & 85.60 & 85.34 & 10/9/93 & 82.63 & 82.47 & $6 / 6196$ & 87.23 & 86.91 \\
\hline $6 / 16 / 88$ & 81.09 & 80.98 & $2 / 12 / 91$ & 86.97 & 86.66 & $10 / 10 / 93$ & 82.50 & 82.34 & $6 / 796$ & 86.84 & 86.53 \\
\hline $6 / 17 / 88$ & 81.31 & 81.19 & $2 / 13 / 91$ & 87.77 & 87.43 & $10 / 11 / 93$ & 82.54 & 82.38 & $6 / 8 / 96$ & 86.59 & 86.29 \\
\hline $6 / 18 / 88$ & 81.58 & 81.45 & $2 / 14 / 91$ & 89.28 & 88.89 & $10 / 12 / 93$ & 82.78 & 82.61 & $6 / 9 / 96$ & 86.85 & 86.54 \\
\hline $6 / 19 / 88$ & 81.52 & 81.40 & $2 / 15 / 91$ & 89.51 & 89.11 & $10 / 13 / 93$ & 82.91 & 82.74 & $6 / 10 / 96$ & 84.67 & 84.44 \\
\hline $6 / 20 / 88$ & 81.31 & 81.19 & $2 / 16 / 91$ & 88.25 & 87.89 & $10 / 14 / 93$ & 82.97 & 82.80 & $6 / 11 / 96$ & 85.03 & 84.79 \\
\hline $6 / 21 / 88$ & 81.16 & 81.05 & $2 / 17 / 91$ & 87.75 & 87.41 & $10 / 15 / 93$ & 82.85 & 82.68 & $6 / 12 / 96$ & 86.70 & 86.40 \\
\hline $6 / 22 / 88$ & 82.28 & 82.13 & $2 / 18 / 91$ & 84.79 & 84.55 & $10 / 16 / 93$ & 82.69 & 82.53 & $6 / 13 / 96$ & 87.28 & 86.96 \\
\hline $6 / 23 / 88$ & 82.81 & 82.64 & $2 / 19 / 91$ & 85.33 & 85.08 & $10 / 17 / 93$ & 82.85 & 82.68 & $6 / 14 / 96$ & 88.27 & 87.91 \\
\hline $6 / 24 / 88$ & 81.52 & 81.40 & $2 / 20 / 91$ & 86.50 & 86.21 & $10 / 18 / 93$ & 82.91 & 82.74 & $6 / 15 / 96$ & 89.79 & 89.38 \\
\hline $6 / 25 / 88$ & 81.21 & 81.10 & $2 / 21 / 91$ & 87.07 & 86.76 & $10 / 19 / 93$ & 83.36 & 83.17 & $6 / 16 / 96$ & 88.89 & 88.51 \\
\hline $6 / 26 / 88$ & 81.20 & 81.09 & $2 / 22 / 91$ & 86.93 & 86.62 & $10 / 20 / 93$ & 83.03 & 82.85 & $6 / 17 / 96$ & 86.73 & 86.43 \\
\hline $6 / 27 / 88$ & 81.33 & 81.21 & $2 / 23 / 91$ & 86.03 & 85.75 & $10 / 21 / 93$ & 82.89 & 82.72 & $6 / 18 / 96$ & 88.07 & 87.72 \\
\hline $6 / 28 / 88$ & 81.45 & 81.33 & $2 / 24 / 91$ & 86.05 & 85.77 & $10 / 22 / 93$ & 82.90 & 82.73 & $6 / 19 / 96$ & 89.41 & 89.01 \\
\hline $6 / 29 / 88$ & 81.31 & 81.19 & $2 / 25 / 91$ & 86.09 & 85.81 & $10 / 23 / 93$ & 83.00 & 82.83 & $6 / 20 / 96$ & 89.61 & 89.21 \\
\hline $6 / 30 / 88$ & 81.30 & 81.18 & $2 / 26 / 91$ & 87.39 & 87.06 & $10 / 24 / 93$ & 83.34 & 83.15 & $6 / 21 / 96$ & 90.35 & 89.92 \\
\hline $7 / 1 / 88$ & 81.79 & 81.66 & $227 / 91$ & 88.08 & 87.73 & $10 / 25 / 93$ & 83.10 & 82.92 & $6 / 22 \sqrt{96}$ & 90.74 & 90.30 \\
\hline $7 / 2 / 88$ & 82.71 & 82.55 & $2 / 28 / 91$ & 88.02 & 87.67 & $10 / 26 / 93$ & 84.56 & 84.33 & $6 / 23 / 96$ & 89.14 & 88.75 \\
\hline $7 / 3 / 88$ & 82.27 & 82.12 & $3 / 1 / 91$ & 87.81 & 87.47 & $10 / 27 / 93$ & 84.13 & 83.92 & $6 / 24 / 96$ & 86.89 & 86.58 \\
\hline $7 / 4 / 88$ & 81.77 & 81.64 & $3 / 2 / 91$ & 87.23 & 86.91 & $10 / 28 / 93$ & 83.72 & 83.52 & $6 / 25 / 96$ & 87.20 & 86.88 \\
\hline $7 / 5 / 88$ & 81.51 & 81.39 & $3 / 3 / 91$ & 89.20 & 88.81 & $10 / 29 / 93$ & 82.97 & 82.80 & $6 / 26 / 96$ & 87.97 & 87.62 \\
\hline $7 / 6 / 88$ & 81.59 & 81.46 & $3 / 4 / 91$ & 92.84 & 92.33 & $10 / 30 / 93$ & & & $6 / 27 / 96$ & 87.45 & 87.12 \\
\hline $7 / 7 / 88$ & 81.69 & 81.56 & $3 / 5 / 91$ & 94.49 & 93.92 & $10 / 31 / 93$ & & & $6 / 28196$ & 87.09 & 86.77 \\
\hline 7/8/88 & 81.54 & 81.42 & $3 / 6 / 91$ & 94.83 & 94.25 & $11 / 1 / 93$ & & & $6 / 29 / 96$ & 86.88 & 86.57 \\
\hline $7 / 9 / 88$ & 81.52 & 81.40 & $3 / 7 / 91$ & 94.31 & 93.75 & $11 / 293$ & 86.26 & 85.97 & $6 / 30 / 96$ & 86.41 & 86.12 \\
\hline $7 / 10 / 88$ & 81.39 & 81.27 & $3 / 8 / 91$ & 94.33 & 93.76 & $11 / 3 / 93$ & 84.84 & 84.60 & $7 / 1 / 96$ & 85.48 & 85.22 \\
\hline $7 / 11 / 88$ & 81.26 & 81.15 & $3 / 9 / 91$ & 94.54 & 93.97 & $11 / 4 / 93$ & 83.76 & 83.56 & $7 / 2 / 96$ & 85.79 & 85.52 \\
\hline $7 / 12 / 88$ & 81.28 & 81.17 & $3 / 10 / 91$ & 94.88 & 94.30 & $11 / 5 / 93$ & 83.37 & 83.18 & $7 / 3 / 96$ & 85.89 & 85.62 \\
\hline $7 / 13 / 88$ & 81.31 & 81.19 & $3 / 11 / 91$ & 95.09 & 94.50 & $11 / 6 / 93$ & 83.11 & 82.93 & $7 / 4 / 96$ & 84.83 & 84.59 \\
\hline $7 / 14 / 88$ & 81.32 & 81.20 & $3 / 12 / 91$ & 94.84 & 94.26 & $11 / 7 / 93$ & 83.12 & 82.94 & $7 / 5 / 96$ & 84.45 & 84.23 \\
\hline $7 / 15 / 88$ & 81.43 & 81.31 & $3 / 13 / 91$ & 93.46 & 92.92 & $11 / 8 / 93$ & 83.63 & 83.43 & $7 / 6 / 96$ & 84.97 & 84.73 \\
\hline $7 / 16 / 88$ & 81.41 & 81.29 & $3 / 14 / 91$ & 91.59 & 91.12 & $11 / 9 / 93$ & 84.30 & 84.08 & $7 / 7 / 96$ & 85.36 & 85.10 \\
\hline $7 / 17 / 88$ & 81.37 & 81.25 & $3 / 15 / 91$ & 90.49 & 90.06 & $11 / 10 / 93$ & 84.15 & 83.94 & $7 / 8 / 96$ & 84.45 & 84.23 \\
\hline $7 / 18 / 88$ & 81.26 & 81.15 & $3 / 16 / 91$ & 88.83 & 88.45 & $11 / 11 / 93$ & 83.97 & 83.76 & 719196 & 85.07 & 84.82 \\
\hline $7 / 19 / 88$ & 81.05 & 80.94 & $3 / 17 / 91$ & 86.43 & 86.14 & $11 / 12 / 93$ & 83.46 & 83.27 & $7 / 10 / 96$ & 84.59 & 84.36 \\
\hline $7 / 20 / 88$ & 81.06 & 80.95 & $3 / 18 / 91$ & 85.55 & 85.29 & $11 / 13 / 93$ & 82.76 & 82.59 & $7 / 11 / 96$ & 84.56 & 84.33 \\
\hline $7 / 21 / 88$ & 81.11 & 81.00 & $3 / 19 / 91$ & 84.42 & 84.20 & $11 / 14 / 93$ & 82.67 & 82.51 & $7 / 12 / 96$ & 84.64 & 84.41 \\
\hline $7 / 22 / 88$ & 81.53 & 81.41 & $3 / 20 / 91$ & 84.54 & 84.31 & $11 / 15 / 93$ & 82.69 & 82.53 & $7 / 13 / 96$ & 84.57 & 84.34 \\
\hline $7 / 23 / 88$ & 81.81 & 81.68 & $3 / 21 / 91$ & 84.55 & 84.32 & $11 / 16 / 93$ & 83.14 & 82.96 & $7 / 14 / 96$ & 84.25 & 84.03 \\
\hline
\end{tabular}


Appendix C (continued)

$\underline{\text { SR-TNX Estimated Historic Daily Mean Elevation }}$

\begin{tabular}{|c|c|c|c|c|c|c|c|c|c|c|c|}
\hline Date & $\begin{array}{c}\text { SR- } \\
\text { Jackson } \\
\text { Elevation } \\
\text { (ft-msl) }\end{array}$ & $\begin{array}{c}\text { SR-TNX } \\
\text { Estimated } \\
\text { Elevation } \\
\text { (ft-msl) }\end{array}$ & Date & $\begin{array}{c}\text { SR- } \\
\text { Jackson } \\
\text { Elevation } \\
\text { (ft-msl) }\end{array}$ & $\begin{array}{c}\text { SR-TNX } \\
\text { Estimated } \\
\text { Elcvation } \\
\text { (ft-msl) }\end{array}$ & Date & \begin{tabular}{|c|} 
SR. \\
Jackson \\
Elevation \\
(ft-msl) \\
\end{tabular} & $\begin{array}{l}\text { SR-TNX } \\
\text { Estimated } \\
\text { Elevation } \\
\text { (ft-msl) }\end{array}$ & Date & $\begin{array}{c}\text { SR- } \\
\text { Jackson } \\
\text { Elevation } \\
\text { (ft-msl) }\end{array}$ & $\begin{array}{c}\text { SR-TNX } \\
\text { Estimated } \\
\text { Elcvation } \\
(\mathrm{ft}-\mathrm{msl}) \\
\end{array}$ \\
\hline $7 / 24 / 88$ & 81.91 & 81.77 & $3 / 22 / 91$ & 84.09 & 83.88 & T1/17/93 & 83.13 & 82.95 & $7 / 15 / 96$ & 85.02 & 84.78 \\
\hline $7 / 25 / 88$ & 81.66 & 81.53 & $3 / 23 / 91$ & 83.37 & 83.18 & $11 / 18 / 93$ & 82.96 & 82.79 & $7 / 16 / 96$ & 85.36 & 85.10 \\
\hline $7 / 26 / 88$ & 81.30 & 81.18 & $3 / 24 / 91$ & 83.17 & 82.99 & $11 / 19 / 93$ & 83.01 & 82.84 & $7 / 17 / 96$ & 84.31 & $\overline{84.09}$ \\
\hline $7 / 27 / 88$ & 81.16 & 81.05 & $3 / 25 / 91$ & 83.38 & 83.19 & $11 / 20 / 93$ & 83.30 & 83.12 & $7 / 18 / 96$ & 84.82 & 84.58 \\
\hline $7 / 28 / 88$ & 81.20 & 81.09 & $3 / 26191$ & 85.53 & 85.27 & $11 / 21 / 93$ & 83.06 & 82.88 & $7 / 19 / 96$ & 83.89 & 83.69 \\
\hline $7 / 29 / 88$ & 81.33 & 81.21 & $3 / 27 / 91$ & 87.07 & 86.76 & $11 / 22 / 93$ & 83.34 & 83.15 & $7 / 20 / 96$ & 85.32 & 85.07 \\
\hline $7 / 30 / 88$ & 81.78 & 81.65 & $3 / 28 / 91$ & 86.95 & 86.64 & $11 / 23 / 93$ & 83.79 & 83.59 & $7 / 21 / 96$ & 85.54 & 85.28 \\
\hline $7 / 31 / 88$ & 81.71 & 81.58 & $3 / 29 / 91$ & 87.23 & 86.91 & $11 / 24 / 93$ & 83.14 & 82.96 & $7 / 22 / 96$ & 83.77 & 83.57 \\
\hline $8 / 1 / 88$ & 81.63 & 81.50 & $3 / 30 / 9]$ & 87.87 & 87.53 & $11 / 25 / 93$ & 83.33 & 83.14 & $7 / 23 / 96$ & 83.54 & 83.35 \\
\hline $8 / 2 / 88$ & 81.47 & 81.35 & $3 / 31 / 91$ & 90.15 & 89.73 & {$[1 / 26 / 93$} & 83.65 & 83.45 & $7 / 24 / 96$ & 84.29 & 84.07 \\
\hline $8 / 3 / 88$ & & & $4 / 1 / 91$ & 90.91 & 90.46 & $11 / 27 / 93$ & 83.57 & 83.38 & $7 / 25 / 96$ & 83.52 & 83.33 \\
\hline $8 / 4 / 88$ & & & $4 / 2 / 91$ & 89.43 & 89.03 & $11 / 28 / 93$ & 83.53 & 83.34 & $7 / 26 \sqrt{96}$ & 85.20 & 84.95 \\
\hline $8 / 5 / 88$ & 81.78 & 81.65 & $4 / 3 / 91$ & 91.35 & 90.89 & $11 / 29 / 93$ & 84.29 & 84.07 & $7 / 27 / 96$ & 83.92 & 83.71 \\
\hline $8 / 6 / 88$ & 81.78 & 81.65 & $4 / 4 / 91$ & 92.97 & 92.45 & $11 / 30 / 93$ & 85.54 & 85.28 & $7 / 28 / 96$ & 83.71 & 83.51 \\
\hline $8 / 7 / 88$ & 81.89 & 81.75 & $4 / 5 / 91$ & 93.95 & 93.40 & $12 / 1 / 93$ & 84.48 & 84.25 & $7 / 29196$ & 83.14 & 82.96 \\
\hline $8 / 8 / 88$ & 82.10 & 81.96 & $4 / 6 / 91$ & 94.56 & 93.99 & $12 / 2 / 93$ & 83.41 & 83.22 & $7 / 30 / 96$ & 85.54 & 85.28 \\
\hline $8 / 9 / 88$ & 82.11 & 81.97 & $4 / 7 / 91$ & 93.60 & 93.06 & $12 / 3 / 93$ & 82.89 & 82.72 & $7 / 31 / 96$ & 85.74 & 85.47 \\
\hline $8 / 10 / 88$ & 82.11 & 81.97 & $4 / 8 / 91$ & 90.32 & 89.89 & $12 / 4 / 93$ & 82.75 & 82.58 & $8 / 1 / 96$ & 86.02 & 85.74 \\
\hline $8 / 11 / 88$ & 82.11 & 81.97 & $4 / 9 / 91$ & 87.31 & 86.99 & $12 / 5 / 93$ & 82.96 & 82.79 & $8 / 2 / 96$ & 85.60 & 85.34 \\
\hline $8 / 12 / 88$ & 82.11 & 81.97 & $4 / 10 / 91$ & 88.68 & 88.31 & $12 / 6 / 93$ & 83.37 & 83.18 & $8 / 3 / 96$ & 85.10 & 84.85 \\
\hline $8 / 13 / 88$ & 82.12 & 81.98 & $4 / 11 / 91$ & 90.67 & 90.23 & $12 / 7 / 93$ & 84.13 & 83.92 & $8 / 4 / 96$ & 84.25 & 84.03 \\
\hline $8 / 14 / 88$ & 82.21 & 82.06 & $4 / 12 / 91$ & 91.97 & 91.49 & $12 / 8 / 93$ & 84.25 & 84.03 & $8 / 5 / 96$ & 83.88 & 83.68 \\
\hline $8 / 15 / 88$ & 82.28 & 82.13 & $4 / 13 / 91$ & 92.16 & 91.67 & $12 / 9 / 93$ & 83.79 & 83.59 & $8 / 6 / 96$ & 85.16 & 84.91 \\
\hline $8 / 16 / 88$ & 82.30 & 82.15 & $4 / 14 / 91$ & 90.29 & 89.86 & $12 / 10 / 93$ & 84.17 & 83.96 & $8 / 7 / 96$ & 85.49 & 85.23 \\
\hline $8 / 17 / 88$ & $82 . \overline{31}$ & 82.16 & $4 / 15 / 91$ & 86.67 & 86.37 & $12 / 11 / 93$ & 83.30 & 83.12 & $8 / 8 / 96$ & 86.24 & 85.95 \\
\hline $8 / 18 / 88$ & 82.38 & 82.23 & $4 / 16 / 91$ & 89.45 & 89.05 & $12 / 12 / 93$ & 82.90 & 82.73 & $8 / 9 / 96$ & 86.01 & 85.73 \\
\hline $8 / 19 / 88$ & 82.37 & 82.22 & $4 / 17 / 91$ & 91.22 & 90.76 & $12 / 13 / 93$ & 83.84 & 83.64 & $8 / 10 / 96$ & 85.90 & 85.63 \\
\hline $8 / 20 / 88$ & 82.42 & 82.27 & $4 / 18 / 91$ & 91.79 & 91.31 & $12 / 14 / 93$ & 84.81 & 84.57 & $8 / 11 / 96$ & 85.28 & 85.03 \\
\hline $8 / 21 / 88$ & 82.60 & 82.44 & $4 / 19 / 91$ & 91.84 & 91.36 & $12 / 15 / 93$ & 85.15 & 84.90 & $8 / 12 / 96$ & 84.24 & 84.02 \\
\hline $8 / 22 / 88$ & 82.65 & 82.49 & $4 / 20 / 91$ & 91.66 & 91.19 & $12 / 16 / 93$ & 84.86 & 84.62 & $8 / 13 / 96$ & 84.61 & 84.38 \\
\hline $8 / 23 / 88$ & 82.77 & 82.60 & $4 / 21 / 91$ & 89.86 & 89.45 & $12 / 17 / 93$ & 84.68 & 84.45 & $8 / 14 / 96$ & 85.56 & 85.30 \\
\hline $8 / 24 / 88$ & 82.83 & 82.66 & $4 / 22 / 91$ & 85.95 & 85.67 & $12 / 18 / 93$ & 84.12 & 83.91 & $8 / 15 / 96$ & 85.49 & 85.23 \\
\hline $8 / 25 / 88$ & 82.95 & 82.78 & $4 / 23 / 91$ & 86.09 & 85.81 & $12 / 19 / 93$ & 83.41 & 83.22 & $8 / 16 / 96$ & 85.15 & 84.90 \\
\hline $8 / 26 / 88$ & 83.03 & 82.85 & $4 / 24 / 91$ & 86.93 & 86.62 & $12 / 20 / 93$ & 83.10 & 82.92 & $8 / 17 / 96$ & 84.68 & 84.45 \\
\hline$=8 / 27 / 88$ & $=83.07$ & 82.89 & $=4 / 25 / 91$ & 86.83 & 86.52 & $=12 / 21 / 93$ & 84.55 & 84.32 & $8 / 18 / 96$ & 83.71 & 83.51 \\
\hline $8 / 28 / 88$ & 83.06 & 82.88 & $4 / 26 / 91$ & 86.83 & 86.52 & $12 / 22 / 93$ & 83.83 & 83.63 & $8 / 19 / 96$ & 83.54 & 83.35 \\
\hline $8 / 29 / 88$ & 83.05 & 82.87 & $4 / 27191$ & 85.74 & 85.47 & $12 / 23 / 93$ & 84.27 & 84.05 & $8 / 20 / 96$ & 84.98 & 84.74 \\
\hline $8 / 30 / 88$ & & & $4 / 28 / 91$ & 84.98 & 84.74 & $12 / 24 / 93$ & 84.41 & 84.19 & $8 / 21 / 96$ & 86.26 & 85.97 \\
\hline $8 / 31 / 88$ & & & $4 / 29191$ & 84.68 & 84.45 & $12 / 25 / 93$ & 84.03 & 83.82 & $8 \longdiv { 2 2 / 9 6 }$ & 86.43 & 86.14 \\
\hline $9 / 1 / 88$ & 82.08 & 81.94 & $4 / 30 / 91$ & 88.26 & 87.90 & $12 / 26 / 93$ & 83.50 & 83.31 & $8 / 23 / 96$ & 86.26 & 85.97 \\
\hline $9 / 2 / 88$ & 82.34 & 82.19 & $5 / 1 / 91$ & 90.87 & 90.42 & $12 / 27 / 93$ & 83.47 & 83.28 & $8 / 24 / 96$ & 85.95 & 85.67 \\
\hline $9 / 3 / 88$ & 81.98 & 81.84 & $5 / 2 / 91$ & 91.62 & 91.15 & $12 / 28 / 93$ & 84.13 & 83.92 & $8 / 25 / 96$ & 85.08 & 84.83 \\
\hline $9 / 4 / 88$ & 81.76 & 81.63 & $5 / 3 / 91$ & 92.54 & 92.04 & $12 / 29 / 93$ & 83.86 & 83.66 & $8 / 26 / 96$ & 84.05 & 83.84 \\
\hline
\end{tabular}


Appendix C (continued)

SR-TNX Estimated Historic Daily Mean Elevation

\begin{tabular}{|c|c|c|c|c|c|c|c|c|c|c|c|}
\hline Date & \begin{tabular}{|c|} 
SR- \\
Jackson \\
Elevation \\
(f-ms') \\
\end{tabular} & $\begin{array}{l}\text { SR-TNX } \\
\text { Estimated } \\
\text { Elevation } \\
\text { (ft-msl) } \\
\end{array}$ & Date & \begin{tabular}{|c|} 
SR- \\
Jackson \\
Elevation \\
(ft-msi) \\
\end{tabular} & $\begin{array}{l}\text { SR-TiNX } \\
\text { Estimated } \\
\text { Elevation } \\
\text { (ft-msl) }\end{array}$ & Date & \begin{tabular}{c|} 
SR- \\
Jackson \\
Elevation \\
$(\mathrm{ft}-\mathrm{msl})$ \\
\end{tabular} & $\begin{array}{c}\text { SR-TNX } \\
\text { Estimated } \\
\text { Elevation } \\
\text { (ft-msl) } \\
\end{array}$ & Date & $\begin{array}{c}\text { SR- } \\
\text { Jackson } \\
\text { Elevation } \\
\text { (ft-msl) }\end{array}$ & $\begin{array}{l}\text { SR-TNX } \\
\text { Estimated } \\
\text { Elevation } \\
\text { (ft-msl) }\end{array}$ \\
\hline $9 / 5 / 88$ & 82.15 & 82.01 & $5 / 4 / 91$ & 93.33 & 92.80 & $12 \sqrt{30 / 93}$ & 83.05 & 82.87 & $8 / 27 / 96$ & 85.25 & 85.00 \\
\hline $9 / 6 / 88$ & 82.34 & 82.19 & $5 / 5 / 91$ & 93.83 & 93.28 & $12 / 31 / 93$ & \begin{tabular}{|l|l|}
85.03 \\
\end{tabular} & $\overline{84.79}$ & $8 / 28 / 96$ & 86.34 & 86.05 \\
\hline $9 / 7 / 88$ & 82.79 & 82.62 & $5 / 6 / 91$ & 94.17 & 93.61 & $1 / 1 / 94$ & 84.28 & 84.06 & $8 / 29 / 96$ & 86.38 & 86.09 \\
\hline $9 / 8 / 88$ & 82.61 & 82.45 & $5 / 7 / 91$ & 94.61 & 94.04 & $1 / 294$ & 83.51 & 83.32 & $8 / 30 / 96$ & 85.88 & 85.61 \\
\hline $9 / 9 / 88$ & 84.20 & 83.98 & $5 / 8 / 91$ & 95.15 & 94.56 & $1 / 3 / 94$ & 84.53 & 84.30 & $8 / 31 / 96$ & 85.81 & 85.54 \\
\hline $9 / 10 / 88$ & 86.65 & 86.35 & $5 / 9 / 91$ & 95.41 & 94.81 & $1 / 4 / 94$ & 85.36 & 85.10 & $9 / 1 / 96$ & 84.16 & 83.95 \\
\hline $9 / 11 / 88$ & 85.93 & 85.65 & $5 / 10 / 91$ & 95.45 & $\overline{94.85}$ & $1 / 5 / 94$ & 86.31 & 86.02 & $9 \longdiv { 2 / 9 6 }$ & 83.31 & 83.13 \\
\hline $9 / 12 / 88$ & 83.86 & 83.66 & $5 / 11 / 91$ & 95.19 & 94.60 & $1 / 6 / 94$ & 86.44 & 86.15 & $9 / 3 / 96$ & 84.34 & 84.12 \\
\hline $9 / 13 / 88$ & 83.41 & 83.22 & $5 / 12 / 91$ & 93.99 & 93.44 & $1 / 7 / 94$ & 85.94 & 85.66 & $9 / 4 / 96$ & 85.14 & 84.89 \\
\hline $9 / 14 / 88$ & 82.66 & 82.50 & $5 / 13 / 91$ & 91.96 & 91.48 & $1 / 8 / 94$ & 84.66 & 84.43 & $9 / 5 / 96$ & 86.29 & 86.00 \\
\hline 9/15/88 & 82.30 & 82.15 & $5 / 14 / 91$ & 91.54 & 91.07 & $19 / 94$ & 83.79 & 83.59 & $9 / 6 \sqrt[96]{ }$ & 86.84 & 86.53 \\
\hline $9 / 16 / 88$ & 82.57 & 82.41 & $5 / 15 / 91$ & 92.32 & 91.82 & $1 / 10 / 94$ & 85.26 & 85.01 & $9 / 7196$ & 86.91 & 86.6 \\
\hline $9 / 17 / 88$ & 82.27 & 82.12 & $5 / 16 / 91$ & 92.61 & 92.10 & $1 / 11 / 94$ & 86.08 & 85.80 & 9/8/96 & 85.48 & 85.22 \\
\hline $9 / 18 / 88$ & 82.15 & 82.01 & $5 / 17 / 91$ & 92.68 & 92.17 & $1 / 12 / 94$ & 84.69 & 84.46 & $9 / 9 / 96$ & \begin{tabular}{|l|l|}
84.33 \\
\end{tabular} & 84.11 \\
\hline $9 / 19 / 88$ & 82.06 & 81.92 & $5 / 18 / 91$ & 92.85 & 92.34 & $1 / 13 / 94$ & 84.44 & 84.22 & $9 / 10 / 96$ & 89.25 & 88.86 \\
\hline $9 / 20 / 88$ & 81.96 & 81.82 & $5 / 19 / 91$ & 92,47 & 91.97 & $1 / 1 / 4 / 94$ & 85.85 & 85.58 & $9 / 11 / 96$ & 89.24 & 88.85 \\
\hline $9 / 2 \mathrm{~V} / 88$ & 82.03 & 81.89 & $5 / 20 / 91$ & 91.85 & 91.37 & $1 / 15 / 94$ & 85.78 & 85.51 & $9 / 12796$ & 87.35 & $\overline{87.03}$ \\
\hline $9 / 22 / 88$ & 82.07 & 81.93 & $5 / 21 / 91$ & \begin{tabular}{|c|}
92.38 \\
\end{tabular} & 91.88 & $1 / 16 / 94$ & 84.60 & 84.37 & $9 / 13 / 96$ & 86.22 & 85.93 \\
\hline $9 / 23 / 88$ & 81.92 & 81.78 & $5 / 22 / 91$ & 92.82 & 92.31 & $1 / 17 / 94$ & 84.80 & 84.56 & $9 / 14 / 96$ & 85.39 & 85.13 \\
\hline $9 / 24 / 88$ & \begin{tabular}{|c|}
81.83 \\
\end{tabular} & 81.70 & $5 / 23 / 91$ & 92.92 & 92.40 & $1 / 18 / 94$ & 85.31 & 85.06 & $9 / 15 / 96$ & 84.91 & 84.67 \\
\hline $9 / 25 / 88$ & 81.74 & 81.61 & $5 / 24 / 91$ & 92.92 & 92.40 & $1 / 19 / 94$ & 86.85 & 86.54 & $9 / 16 / 96$ & 84.19 & 83.97 \\
\hline $9 / 26 / 88$ & 81.78 & 81.65 & $5 / 25 / 91$ & 92.78 & 92.27 & $1 / 20 / 94$ & 89.46 & 89.06 & $9 / 17 / 96$ & 84.50 & 84.27 \\
\hline $9 / 27 / 88$ & 81.71 & 81.58 & $5 / 26 / 91$ & 91.95 & 91.47 & $1 / 21 / 94$ & 90.10 & \begin{tabular}{|c|}
89.68 \\
\end{tabular} & $9 / 18 / 96$ & 84.88 & 84.64 \\
\hline $9 / 28 / 88$ & 81.67 & 81.54 & $5 / 27 / 91$ & 90.50 & 90.07 & $1 / 22 / 94$ & 88.71 & 88.34 & $9 / 19 / 96$ & 85.24 & 84.99 \\
\hline $9 / 29 / 88$ & 81.57 & 81.45 & $5 / 28 / 91$ & 91.41 & 90.95 & $1 / 23 / 94$ & 86.65 & 86.35 & $9 / 20 / 96$ & 85.27 & 85.02 \\
\hline $9 / 30 / 88$ & 81.80 & 81.67 & $5 / 29 / 91$ & 92.45 & 91.95 & $1 / 24 / 94$ & 84.10 & 83.89 & $9 / 21 / 96$ & 84.59 & 84.36 \\
\hline $10 / 1 / 88$ & 81.74 & 81.61 & $5 / 30 / 91$ & 92.93 & 92.41 & $1 / 25 / 94$ & 84.37 & 84.15 & $9 / 22 / 96$ & 84.47 & 84.25 \\
\hline $10 / 2 / 88$ & 81.66 & 81.53 & $5 / 31 / 91$ & 92.84 & 92.33 & $1 / 26 / 94$ & 84.77 & 84.53 & $9 / 23 / 96$ & 83.81 & 83.61 \\
\hline $10 / 3 / 88$ & 81.62 & 81.49 & $6 / 1 / 91$ & 92.36 & 91.86 & $1 / 27 / 94$ & \begin{tabular}{|c|}
83.93 \\
\end{tabular} & 83.72 & $9 / 24 / 96$ & 84.51 & 84.28 \\
\hline $10 / 4 / 88$ & 84.05 & 83.84 & $6 / 2 / 91$ & 90.60 & 90.16 & $1 / 28 / 94$ & 83.99 & 83.78 & $9 / 25 / 96$ & 85.74 & 85.47 \\
\hline $10 / 5 / 88$ & 89.74 & 89.33 & $6 / 3 / 91$ & 89.51 & 89.11 & $1 / 29 / 94$ & 84.35 & \begin{tabular}{|l|}
84.13 \\
\end{tabular} & $9 / 26 \sqrt{96}$ & 85.57 & 85.31 \\
\hline $10 / 6 / 88$ & $\begin{array}{l}87.90 \\
\end{array}$ & 87.56 & $6 / 4 / 91$ & 89.79 & 89.38 & $1 / 30 / 94$ & 84.66 & 84.43 & $9 / 27 / 96$ & 85.53 & 85.27 \\
\hline $10 / 7 / 88$ & 84.12 & 83.91 & $6 / 5 / 91$ & 88.64 & 88.27 & $1 / 31 / 94$ & 86.57 & 86.27 & $9 / 28 / 96$ & 85.70 & 85.43 \\
\hline $10 / 8 / 88$ & 83.13 & 82.95 & $6 / 6 / 91$ & 87.13 & 86.81 & $2 / 194$ & 85.27 & $\begin{array}{l}85.02 \\
\end{array}$ & $9 / 29196$ & 84.80 & 84.56 \\
\hline $10 / 9 / 88$ & 83.06 & 82.88 & $6 / 7 / 91$ & 85.29 & 85.04 & $2 \sqrt[2]{94}$ & 84.83 & $\begin{array}{l}84.59 \\
\end{array}$ & $9 \longdiv { 9 0 / 9 6 }$ & 83.90 & 83.69 \\
\hline $10 / 10 / 88$ & 82.14 & 82.00 & $6 / 8 / 91$ & 85.09 & 84.84 & $2 \sqrt{3 / 94}$ & 84.86 & 84.62 & $10 / 1 / 96$ & & \\
\hline $10 / 11 / 88$ & 81.92 & 81.78 & $6 / 9 / 91$ & 84.17 & 83.96 & $2 / 4 / 94$ & 84.78 & 84.54 & $10 / 2 / 96$ & 86.51 & 86.21 \\
\hline $10 / 12 / 88$ & \begin{tabular}{|l|}
81.74 \\
\end{tabular} & 81.61 & $6 / 10 / 91$ & 83.82 & 83.62 & $2 / 5 / 94$ & & & $10 / 3 / 96$ & 87.45 & 87.12 \\
\hline $10 / 13 / 88$ & $81.61 \mid$ & 81.48 & $6 / 11 / 91$ & 84.89 & 84.65 & $2 / 6 / 94$ & 83.62 & 83.42 & $10 / 4 / 96$ & \begin{tabular}{|c|}
87.36 \\
\end{tabular} & 87.04 \\
\hline $10 / 14 / 88$ & 82.10 & 81.96 & $6 / 12 / 91$ & 84.68 & 84.45 & $2 / 7 / 94$ & 86.18 & 85.90 & $10 / 5 / 96$ & 87.18 & 86.86 \\
\hline $10 / 15 / 88$ & 81.99 & 81.85 & $6 / 13 / 91$ & 85.64 & 85.37 & $2 / 8 / 94$ & 86.07 & 85.79 & $10 / 6 / 96$ & 86.73 & 86.43 \\
\hline $10 / 16 / 88$ & 81.72 & 81.59 & $6 / 14 / 91$ & 85.63 & 85.37 & $2 / 9 / 94$ & 86.29 & 86.00 & $10 / 7 / 96$ & 86.16 & 85.88 \\
\hline $10 / 17 / 88$ & 81.61 & 81.48 & $6 / 15 / 91$ & 86.33 & 86.04 & $2 / 10 / 94$ & 87.28 & 86.96 & $10 / 8 / 96$ & \begin{tabular}{|c|}
87.97 \\
\end{tabular} & $\overline{87.62}$ \\
\hline
\end{tabular}


Appendix C (continued)

SR-TNX Estimated Historic Daily Mean Elevation

\begin{tabular}{|c|c|c|c|c|c|c|c|c|c|c|c|}
\hline Date & $\begin{array}{c}\text { SR- } \\
\text { Jackson } \\
\text { Elevation } \\
\text { (ft-msl) }\end{array}$ & $\begin{array}{c}\text { SR-TNX } \\
\text { Estimated } \\
\text { Elevation } \\
(f t-m s l)\end{array}$ & Date & $\begin{array}{c}\text { SR- } \\
\text { Jackson } \\
\text { Elevation } \\
\text { (f-msl) }\end{array}$ & $\begin{array}{c}\text { SR-TNX } \\
\text { Estimated } \\
\text { Elevation } \\
(f t-m s l)\end{array}$ & Date & $\begin{array}{c}\text { SR- } \\
\text { Jackson } \\
\text { Elevation } \\
\text { (ft-msl) }\end{array}$ & $\begin{array}{c}\text { SR-TNX } \\
\text { Estimated } \\
\text { Elevation } \\
\text { (ft-msl) }\end{array}$ & Date & $\begin{array}{c}\text { SR- } \\
\text { Jackson } \\
\text { Elevation } \\
\text { (f-msl) }\end{array}$ & \begin{tabular}{c|} 
SR-TNX \\
Estimated \\
Elevation \\
(ft-msl)
\end{tabular} \\
\hline $10 / 18 / 88$ & 81.55 & 81.43 & $6 / 16 / 91$ & 87.49 & 87.16 & $2 / 11 / 94$ & 88.16 & 87.81 & $10 / 9 / 96$ & 89.36 & 88.97 \\
\hline $10 / 19 / 88$ & 81.83 & 81.70 & $6 / 17 / 91$ & 86.11 & 85.83 & $2 / 12 / 94$ & 89.24 & 88.85 & $10 / 10 / 96$ & 90.87 & 90.42 \\
\hline $10 / 20 / 88$ & 81.70 & 81.57 & $6 / 18 / 91$ & 86.13 & 85.85 & $2 / 13 / 94$ & 88.16 & 87.81 & $10 / 11 / 96$ & 91.13 & 90.68 \\
\hline $10 / 21 / 88$ & 81.82 & 81.69 & $6 / 19 / 91$ & 87.01 & 86.70 & $2 / 14 / 94$ & 86.90 & 86.59 & $10 / 12 / 96$ & 91.20 & 90.74 \\
\hline $10 / 22 / 88$ & 81.93 & 81.79 & $6 / 20 \% 1$ & 86.64 & 86.34 & $2 / 15 / 94$ & 86.49 & 86.20 & $10 / 13 / 96$ & 89.11 & 88.72 \\
\hline $10 / 23 / 88$ & 81.94 & 81.80 & $6 / 21 / 91$ & 87.53 & 87.20 & $2 / 16 / 94$ & 85.91 & 85.64 & $10 / 14 / 96$ & 85.73 & 85.46 \\
\hline $10 / 24 / 88$ & 81.80 & 81.67 & $6 / 22 / 91$ & 85.77 & 85.50 & $2 / 17 / 94$ & 84.92 & 84.68 & $10 / 15 / 96$ & 84.89 & 84.65 \\
\hline $10 / 25 / 88$ & 81.59 & 81.46 & $6 / 23 / 91$ & 85.07 & 84.82 & $2 / 18 / 94$ & 83.46 & 83.27 & $10 / 16 / 96$ & 86.19 & 85.91 \\
\hline $10 / 26 / 88$ & 82.09 & 81.95 & $6 / 24 / 91$ & 85.11 & 84.86 & $2 / 19 / 94$ & 83.29 & 83.11 & $10 / 17 / 96$ & 86.14 & 85.86 \\
\hline $10 / 27 / 88$ & 82.33 & 82.18 & $6 / 25 / 91$ & 84.66 & 84.43 & $2 / 20 / 94$ & 83.48 & 83.29 & $10 / 18 / 96$ & 86.31 & 86.02 \\
\hline $10 / 28 / 88$ & 82.40 & 82.25 & $6 / 26 / 91$ & 84.84 & 84.60 & $2 / 21 / 94$ & 83.65 & 83.45 & $10 / 19 / 96$ & 86.39 & 86.10 \\
\hline $10 / 29 / 88$ & 81.91 & 81.77 & $6 / 27 / 91$ & 88.97 & 88.59 & $2 / 22 / 94$ & 84.14 & 83.93 & $10 / 20 / 96$ & 84.33 & 84.11 \\
\hline $10 / 30 / 88$ & 81.73 & 81.60 & $6 / 28 / 91$ & 91.23 & 90.77 & $2 / 2364$ & 85.12 & 84.87 & $10 / 21 / 96$ & 85.00 & 84.76 \\
\hline $10 / 31 / 88$ & 81.67 & 81.54 & $6 / 29 / 91$ & 91.61 & 91.14 & $2 / 24 / 94$ & 86.28 & 85.99 & $10 / 22 / 96$ & 84.59 & 84.36 \\
\hline $11 / 1 / 88$ & 81.92 & 81.78 & $6 / 30 / 91$ & 90.11 & 89.69 & $2 / 25 / 94$ & 88.02 & 87.67 & $10 / 23 / 96$ & 84.14 & 83.93 \\
\hline $11 / 2 / 88$ & 82.43 & 82.28 & 7/191 & $88, \overline{16}$ & 87.81 & $2 / 26 / 94$ & 88.34 & 87.98 & $10 / 24 / 96$ & 84.33 & 84.11 \\
\hline $11 / 3 / 88$ & 82.24 & 82.09 & $7 / 2 / 91$ & 89.32 & 88.93 & $2 / 27 / 94$ & 85.72 & 85.45 & $10 / 25 / 96$ & 82.98 & 82.81 \\
\hline $11 / 4 / 88$ & 82.27 & 82.12 & $7 / 3 / 91$ & 91.29 & 90.83 & $2 / 28 / 94$ & 85.63 & 85.37 & $10 / 26 / 96$ & 83.49 & 83.30 \\
\hline $11 / 5 / 88$ & 82.21 & 82.06 & $7 / 4 / 91$ & 91.94 & 91.46 & $3 / 1 / 94$ & 86.05 & 85.77 & $10 / 27 / 96$ & 83.37 & $\overline{83.18}$ \\
\hline $11 / 6 / 88$ & 82.29 & 82.14 & $7 / 5 / 91$ & 92.34 & 91.84 & $3 / 2 / 94$ & 87.13 & 86.81 & $10 / 28 / 96$ & 83.18 & 83.00 \\
\hline $11 / 7 / 88$ & 82.10 & 81.96 & $7 / 6 / 91$ & 92.49 & 91.99 & $3 / 3 / 94$ & 90.93 & 90.48 & $10 / 29 / 96$ & 83.76 & $\overline{83.56}$ \\
\hline $11 / 8 / 88$ & 81.96 & 81.82 & $7 / 7 / 91$ & 91.14 & 90.68 & $3 / 4 / 94$ & 92.78 & 92.27 & $10 / 30 / 96$ & 83.84 & 83.64 \\
\hline $11 / 9 / 88$ & 81.90 & 81.76 & $7 / 8 / 91$ & 89.04 & 88.66 & $3 / 5 / 94$ & 91.55 & 91.08 & $10 / 31 / 96$ & 83.29 & 83.11 \\
\hline $11 / 10 / 88$ & 81.92 & 81.78 & 7/9/91 & 87.09 & 86.77 & $3 / 6 / 94$ & 87.59 & 87.26 & $11 / 1 / 96$ & 83.31 & 83.13 \\
\hline $11 / 11 / 88$ & 81.92 & 81.78 & $7 / 10 / 91$ & 87.33 & 87.01 & $3 / 7 / 94$ & 86.24 & 85.95 & $11 / 2 / 96$ & 82.91 & 82.74 \\
\hline $11 / 12 / 88$ & 81.97 & 81.83 & $7 / 11 / 91$ & 87.79 & 87.45 & $3 / 8 / 94$ & 86.21 & 85.93 & $11 / 3 / 96$ & 83.22 & 83.04 \\
\hline $11 / 13 / 88$ & 81.95 & 81.81 & $7 / 12 / 91$ & 87.46 & 87.13 & $3 / 9 / 94$ & 84.27 & 84.05 & $11 / 4 / 96$ & 83.67 & $\overline{83.47}$ \\
\hline $11 / 14 / 88$ & 81.82 & 81.69 & $7 / 13 / 91$ & 85.98 & 85.70 & $3 / 10 / 94$ & 86.91 & 86.60 & $11 / 5 / 96$ & 83.75 & 83.55 \\
\hline $11 / 15 / 88$ & 81.73 & 81.60 & $7 / 14 / 91$ & 85.10 & 84.85 & $3 / 11 / 94$ & 89.49 & 89.09 & $11 / 6 / 96$ & 83.12 & 82.94 \\
\hline $11 / 16 / 88$ & 81.84 & 81.71 & $7 / 15 / 91$ & 84.42 & 84.20 & $3 / 12 / 94$ & 89.16 & 88.77 & $11 / 7 / 96$ & 83.57 & 83.38 \\
\hline $11 / 17 / 88$ & 82.23 & 82.08 & $7 / 16 / 91$ & 86.57 & 86.27 & $3 / 13 / 94$ & 86.02 & 85.74 & $11 / 8 / 96$ & 83.65 & 83.45 \\
\hline $11 / 18 / 88$ & 82.39 & 82.24 & $7 / 17 / 91$ & 88.76 & 88.39 & $3 / 14 / 94$ & 85.20 & 84.95 & $11 / 9 / 96$ & 83.88 & 83.68 \\
\hline $11 / 19 / 88$ & 82.25 & 82.10 & $7 / 18 / 91$ & 89.57 & 89.17 & $3 / 15 / 94$ & 86.66 & 86.36 & $11 / 10 / 96$ & 84.40 & 84.18 \\
\hline $11 / 20 / 88$ & 82.18 & 82.03 & $7 / 19 / 91$ & 90.27 & 89.84 & $3 / 16 / 94$ & 87.33 & 87.01 & $11 / 11 / 96$ & 84.89 & 84.65 \\
\hline$=11 / 21 / 88$ & $=82.08$ & 81.94 & $=7 / 20191$ & $=90.27$ & 89.84 & $=3 / 17 / 94$ & 87.85 & 87.51 & $=11 / 12 / 96$ & 83.94 & 83.73 \\
\hline $11 / 22 / 88$ & 81.84 & 81.71 & $721 / 91$ & 88.07 & 87.72 & $3 / 18 / 94$ & 87.90 & 87.56 & $11 / 13 / 96$ & 83.62 & 83.42 \\
\hline $11 / 23 / 88$ & 81.85 & 81.72 & 722191 & 86.95 & 86.64 & $3 / 19 / 94$ & 86.37 & 86.08 & $11 / 14 / 96$ & 83.57 & 83.38 \\
\hline $11 / 24 / 88$ & 82.01 & 81.87 & $7 / 23 / 91$ & 87.69 & 87.35 & $3 / 20 / 94$ & 85.51 & 85.25 & $11 / 15 / 96$ & 83.32 & 83.13 \\
\hline $11 / 25 / 88$ & 82.03 & 81.89 & $7 / 24 / 91$ & 86.77 & $86 . \overline{47}$ & $3 / 21 / 94$ & 84.60 & 84.37 & $11 / 16 / 96$ & 83.00 & 82.83 \\
\hline $11 / 26 / 88$ & 82.56 & 82.40 & $7 / 25191$ & 87.24 & 86.92 & $3 / 22 / 94$ & 84.47 & 84.25 & $11 / 17 / 96$ & 82.72 & 82.56 \\
\hline $11 / 27 / 88$ & 82.31 & 82.16 & $7 / 26 / 91$ & 88.00 & 87.65 & $3 / 23 / 94$ & 84.60 & 84.37 & $11 / 18 / 96$ & 83.44 & 83.25 \\
\hline $11 / 28 / 88$ & 81.87 & 81.73 & $7 / 27 / 91$ & 86.21 & 85.93 & $3 / 24 / 94$ & 84.64 & 84.41 & $11 / 19 / 96$ & 83.81 & 83.61 \\
\hline $11 / 29 / 88$ & 81.76 & 81.63 & $7 / 28 / 91$ & 85.42 & 85.16 & $3 / 25 / 94$ & 86.41 & 86.12 & $11 / 20 / 96$ & 83.45 & 83.26 \\
\hline
\end{tabular}


Appendix C (continued)

\section{SR-TNX Estimated Historic Daily Mean Elevation}

\begin{tabular}{|c|c|c|c|c|c|c|c|c|c|c|c|}
\hline Date & \begin{tabular}{|c|} 
SR- \\
Jackson \\
Elevation \\
(ft-msl) \\
\end{tabular} & $\begin{array}{c}\text { SR-TNX } \\
\text { Estimated } \\
\text { Elevation } \\
\text { (ft-msl) } \\
\end{array}$ & Date & $\begin{array}{c}\text { SR- } \\
\text { Jackson } \\
\text { Elevation } \\
(\mathrm{ft}-\mathrm{ms}) \\
\end{array}$ & $\begin{array}{c}\text { SR-TNX } \\
\text { Estimated } \\
\text { Elcvation } \\
\text { (fi-msl) } \\
\end{array}$ & Date & $\begin{array}{c}\text { SR- } \\
\text { Jackson } \\
\text { Elevation } \\
\text { (ft-msl) }\end{array}$ & $\begin{array}{c}\text { SR-TNX } \\
\text { Estimated } \\
\text { Elevation } \\
\text { (ft-msl) }\end{array}$ & Date & \begin{tabular}{|c|} 
SR- \\
Jackson \\
Elevation \\
(ft-msi)
\end{tabular} & $\begin{array}{c}\text { SR-TNX } \\
\text { Estimated } \\
\text { Elevation } \\
\text { (ft-msl) }\end{array}$ \\
\hline $11 / 30 / 88$ & 82.01 & 81.87 & $7 / 29 / 91$ & 86.57 & 86.27 & $3 / 26 / 94$ & 89.27 & 88.88 & $11 / 21 / 96$ & 82.66 & 82.50 \\
\hline $12 / 1 / 88$ & 82.07 & 81.93 & $7 / 30 / 91$ & 90.10 & 89.68 & $3 / 27 / 94$ & 89.64 & 89.24 & $11 / 22 / 96$ & 82.40 & 82.25 \\
\hline $12 / 2 / 88$ & 82.14 & 82.00 & $7 / 31 / 91$ & 92.13 & 91.64 & $3 / 28 / 94$ & 87.81 & 87.47 & $11 / 23 / 96$ & 82.38 & 82.23 \\
\hline $12 / 3 / 88$ & 82.15 & 82.01 & $8 / 1 / 91$ & 92.44 & 91.94 & $3 / 29 / 94$ & 89.07 & 88.69 & $11 / 24 / 96$ & 82.24 & 82.09 \\
\hline $12 / 4 / 88$ & 82.05 & 81.91 & $8 / 2 / 91$ & 92.74 & 92.23 & $3 / 30 / 94$ & 91.01 & 90.56 & $11 / 25 / 96$ & 82.30 & 82.15 \\
\hline $12 / 5 / 88$ & 81.91 & 81.77 & $8 / 3 / 91$ & 93.06 & 92.54 & $3 / 31 / 94$ & 92.13 & 91.64 & $11 / 26 / 96$ & 82.37 & 82.22 \\
\hline $12 / 6 / 88$ & 81.82 & 81.69 & $8 / 4 / 91$ & 92.78 & 92.27 & $4 / 1 / 94$ & 91.39 & 90.93 & $11 / 27 / 96$ & 82.62 & $\overline{82.46}$ \\
\hline $12 / 7 / 88$ & 81.80 & 81.67 & $8 / 5 / 91$ & 91.96 & 91.48 & $4 / 2 / 94$ & 90.48 & 90.05 & $11 / 28 / 96$ & 83.21 & 83.03 \\
\hline $12 / 8 / 88$ & 81.77 & 81.64 & $8 / 6 / 91$ & 92.60 & 92.09 & $4 / 3 / 94$ & 87.86 & 87.52 & $11 / 29 / 96$ & 83.15 & 82.97 \\
\hline $12 / 9 / 88$ & 81.69 & 81.56 & $8 / 7 / 91$ & 93.38 & 92.85 & $4 / 4 / 94$ & 84.76 & 84.53 & $11 / 30 / 96$ & 83.11 & 82.93 \\
\hline $12 / 10 / 88$ & 81.85 & 81.72 & $8 / 8 / 91$ & 93.74 & 93.20 & $4 / 5 / 94$ & 86.74 & 86.44 & $12 / 1 / 96$ & 83.05 & 82.87 \\
\hline $12 / 11 / 88$ & 81.90 & 81.76 & $8 / 9 / 91$ & 93.27 & 92.74 & $4 / 6 / 94$ & 87.37 & 87.05 & $12 / 2 / 96$ & 83.47 & 83.28 \\
\hline $12 / 12 / 88$ & 81.84 & 81.71 & $8 / 10 / 91$ & 91.99 & 91.51 & $4 / 7 / 94$ & 87.33 & 87.01 & $12 / 3 / 96$ & 85.37 & 85.11 \\
\hline $12 / 13 / 88$ & 81.81 & 81.68 & $8 / 11 / 91$ & 90.32 & 89.89 & $4 / 8 / 94$ & 86.55 & 86.25 & $12 / 4 / 96$ & 85.91 & $\overline{85.64}$ \\
\hline $12 / 14 / 88$ & 81.88 & 81.74 & $8 / 12 / 91$ & 89.32 & 88.93 & $4 / 9 / 94$ & 85.79 & 85.52 & $12 / 5 / 96$ & 84.82 & 84.58 \\
\hline $12 / 15 / 88$ & 81.94 & 81.80 & $8 / 13 / 91$ & \begin{tabular}{l|}
89.41 \\
\end{tabular} & 89.01 & $4 / 10 / 94$ & 84.85 & 84.61 & $12 / 6 / 96$ & 84.95 & 84.71 \\
\hline $12 / 16 / 88$ & 82.10 & 81.96 & $8 / 14 / 91$ & 92.00 & 91.52 & $4 / 11 / 94$ & 85.32 & 85.07 & $12 / 7 / 96$ & 85.43 & 85.17 \\
\hline $12 / 17 / 88$ & 82.06 & 81.92 & $8 / 15 / 91$ & 93.42 & 92.89 & $4 / 12 / 94$ & 88.28 & 87.92 & $12 / 8 / 96$ & 85.49 & 85.23 \\
\hline $12 / 18 / 88$ & 81.73 & 81.60 & $8 / 16 / 91$ & 94.18 & 93.62 & $4 / 13 / 94$ & 89.42 & 89.02 & $12 / 9 / 96$ & 84.94 & 84.70 \\
\hline $12 / 19 / 88$ & 81.64 & 81.51 & $8 / 17 / 91$ & 94.40 & 93.83 & $4 / 14 / 94$ & 89.98 & 89.56 & $12 / 10 / 96$ & 85.57 & 85.31 \\
\hline $12 / 20 / 88$ & 81.55 & 81.43 & $8 / 18 / 91$ & 94.19 & 93.63 & $4 / 15 / 94$ & 89.86 & 89.45 & $12 / 11 / 96$ & 85.76 & 85.49 \\
\hline $12 / 21 / 88$ & 81.65 & 81.52 & $8 / 19 / 91$ & 92.64 & 92.13 & $4 / 16 / 94$ & 90.14 & 89.72 & $12 / 12 / 96$ & 84.50 & 84.27 \\
\hline $12 / 22 / 88$ & 81.66 & 81.53 & $8 / 20 / 91$ & 89.84 & 89.43 & 4/17/94 & 88.30 & 87.94 & $12 / 13 / 96$ & 84.67 & 84.44 \\
\hline $12 / 23 / 88$ & 81.65 & 81.52 & $8 / 21 / 91$ & 89.99 & 89.57 & $4 / 18 / 94$ & 85.26 & 85.01 & $12 / 14 / 96$ & 84.67 & 84.44 \\
\hline $12 / 24 / 88$ & 81.50 & 81.38 & $8 / 22 / 91$ & 91.46 & 90.99 & $4 / 19 / 94$ & 83.61 & 83.41 & $12 / 5 / 96$ & 85.27 & 85.02 \\
\hline $12 / 25 / 88$ & 81.51 & 81.39 & $8 / 23 / 91$ & 92.62 & 92.11 & $4 / 20 / 94$ & 84.92 & 84.68 & $12 / 16 / 96$ & 85.24 & 84.99 \\
\hline $12 / 26 / 88$ & 81.50 & 81.38 & $8 / 24 / 91$ & 92.46 & 91.96 & $4 / 21 / 94$ & 84.48 & 84.25 & $12 / 17 / 96$ & 85.46 & 85.20 \\
\hline $12 / 27 / 88$ & 81.56 & 81.44 & $8 \longdiv { 2 5 / 9 1 }$ & 92.22 & 91.73 & $4 / 22 / 94$ & 86.26 & 85.97 & $12 / 18 / 96$ & 85.52 & 85.26 \\
\hline $12 / 28 / 88$ & 81.58 & 81.45 & $8 / 26 / 91$ & 91.58 & 91.11 & $4 / 23 / 94$ & 84.80 & 84.56 & $12 / 19 / 96$ & 85.02 & 84.78 \\
\hline $12 / 29 / 88$ & 81.53 & 81.41 & $8 / 27 / 91$ & 90.58 & 90.14 & $4 / 24 / 94$ & 83.25 & 83.07 & $12 / 20 / 96$ & 85.86 & 85.59 \\
\hline $12 / 30 / 88$ & 81.93 & 81.79 & $8 / 28 / 91$ & 89.24 & 88.85 & $4 / 25 / 94$ & 84.81 & 84.57 & $12 / 21 / 96$ & 88.50 & 88.14 \\
\hline $12 / 31 / 88$ & 81.88 & 81.74 & $8 / 29191$ & 88.86 & 88.48 & $4 / 26 / 94$ & 87.00 & 86.69 & $12 / 22 / 96$ & 88.76 & 88.39 \\
\hline $1 / 1 / 89$ & 82.22 & 82.07 & $8 / 30 / 91$ & 91.74 & 91.26 & $4 / 27 / 94$ & 87.48 & 87.15 & $12 / 23 / 96$ & 88.24 & 87.89 \\
\hline $1 / 2 / 89$ & 82.41 & 82.26 & $8 / 31 / 91$ & 92.09 & 91.60 & $4 / 28 / 94$ & 87.23 & 86.91 & $12 / 24 / 96$ & 85.47 & 85.21 \\
\hline $1 / 3 / 89$ & 82.24 & 82.09 & $9 / 191$ & 89.48 & 89.08 & $4 / 29 / 94$ & 85.76 & 85.49 & $12 / 25 / 96$ & 84.15 & 83.94 \\
\hline $1 / 4 / 89$ & 82.22 & 82.07 & $9 / 2 / 91$ & 85.28 & 85.03 & $4 / 30 / 94$ & 86.28 & 85.99 & $12 / 26 \times 96$ & 84.43 & 84.21 \\
\hline $1 / 5 / 89$ & 83.06 & 82.88 & $9 / 3 / 91$ & 83.94 & 83.73 & $5 / 194$ & 84.83 & 84.59 & $12 / 27 / 96$ & 84.43 & 84.21 \\
\hline $1 / 6 / 89$ & 83.81 & 83.61 & $9 / 4 / 91$ & 83.65 & 83.45 & $5 / 2 / 94$ & 83.23 & 83.05 & $12 / 28 / 96$ & 84.33 & 84.11 \\
\hline $1 / 7 / 89$ & 82.25 & 82.10 & $9 / 5 / 91$ & 84.06 & 83.85 & $5 / 3 / 94$ & 85.51 & 85.25 & $12 / 29 / 96$ & 84.24 & $8 \overline{4.02}$ \\
\hline $1 / 8 / 89$ & 81.58 & 81.45 & $9 / 6 / 91$ & 83.82 & 83.62 & $5 / 4 / 94$ & 85.04 & 84.80 & $12 / 30 / 96$ & 84.18 & 83.97 \\
\hline $19 / 89$ & 81.56 & 81.44 & $9 / 7 / 91$ & 83.49 & 83.30 & $5 / 5194$ & 85.35 & 85.09 & $12 / 31 / 96$ & 84.02 & 83.81 \\
\hline $1 / 10 / 89$ & 81.58 & 81.45 & $9 / 8 / 91$ & 83.70 & 83.50 & $5 / 6 / 94$ & 84.70 & 84.47 & $1 / 1 / 97$ & 83.38 & 83.19 \\
\hline $1 / 11 / 89$ & 82.63 & 82.47 & $9 / 9 / 91$ & 84.72 & 84.49 & $5 / 7 / 94$ & 83.41 & 83.22 & $1 / 2 / 97$ & 82.77 & 82.60 \\
\hline
\end{tabular}


Appendix C (continued)

SR-TNX Estimated Historic Daily Mean Elevation

\begin{tabular}{|c|c|c|c|c|c|c|c|c|c|c|c|}
\hline Date & \begin{tabular}{|c|} 
SR- \\
Jackson \\
Elevation \\
(fl-msl)
\end{tabular} & $\begin{array}{c}\text { SR-TNXX } \\
\text { Estimated } \\
\text { Elevation } \\
\text { (ft-msl) }\end{array}$ & Date & \begin{tabular}{c|} 
SR- \\
Jackson \\
Elevation \\
(ft-msl)
\end{tabular} & \begin{tabular}{|c|} 
SR-TNX \\
Estimated \\
Elevation \\
(ft-msl)
\end{tabular} & Date & \begin{tabular}{|c|} 
SR- \\
Jackson \\
Elevation \\
(ft-msl)
\end{tabular} & $\begin{array}{c}\text { SR-TNX } \\
\text { Estimated } \\
\text { Elevation } \\
\text { (ft-msl) }\end{array}$ & Date & \begin{tabular}{|c|} 
SR- \\
Jackson \\
Elevation \\
(ft-msl)
\end{tabular} & \begin{tabular}{c|} 
SR-TNX \\
Estimated \\
Elevation \\
(ft-msl)
\end{tabular} \\
\hline $1 / 12 / 89$ & 83.56 & 83.37 & $9 / 10 / 91$ & 85.46 & 85.20 & $5 / 8 / 94$ & 82.98 & 82.81 & $1 / 3 / 97$ & 83.93 & 83.72 \\
\hline $1 / 13 / 89$ & 83.08 & 82.90 & $9 / 11 / 91$ & 87.28 & 86.96 & $5 / 9 / 94$ & 83.92 & 83.71 & 1/4/97 & 84.89 & 84.65 \\
\hline $1 / 14 / 89$ & 82.45 & 82.29 & $9 / 12 / 91$ & $\begin{array}{l}87.76 \\
\end{array}$ & 87.42 & $5 / 10 / 94$ & $84.17 \mid$ & 83.96 & \begin{tabular}{|l|}
$/ 5 / 97$ \\
\end{tabular} & \begin{tabular}{l|l|}
84.40 \\
\end{tabular} & 84.18 \\
\hline $1 / 15 / 89$ & 83.55 & 83.36 & $9 / 13 / 91$ & 88.14 & \begin{tabular}{|l|l|}
87.79 \\
\end{tabular} & $5 / 11194$ & 84.11 & 83.90 & \begin{tabular}{|l|l|}
$1 / 6 / 97$ \\
\end{tabular} & 84.25 & 84.03 \\
\hline $1 / 16 / 89$ & 82.19 & 82.04 & $9 / 14 / 91$ & 86.86 & $86.55 \mid$ & $5 / 12 / 94$ & 84.31 & 84.09 & $1 / 7 / 97$ & 84.86 & 84.62 \\
\hline $1 / 17 / 89$ & 81.82 & 81.69 & $9 / 15 / 91$ & 85.34 & 85.09 & $5 / 13 / 94$ & 84.00 & 83.79 & \begin{tabular}{|l|}
$1 / 8 / 97$ \\
\end{tabular} & 86.06 & 85.78 \\
\hline $1 / 18 / 89$ & 81.98 & 81.84 & $9 / 16 / 91$ & 84.42 & 84.20 & $5 / 14 / 94$ & 82.81 & 82.64 & $1 / 9 / 97$ & 87.91 & 87.57 \\
\hline $1 / 19 / 89$ & 82.99 & 82.82 & 9/17/91 & 85.52 & 85 & $5 / 15 / 94$ & 82.76 & 82.59 & $1 / 10 / 97$ & 90.86 & $\overline{90.41}$ \\
\hline $1 / 20 / 89$ & 82.46 & 82.30 & $9 / 18 / 91$ & 86.05 & 85.77 & $5 / 16 \sqrt{94}$ & 83.13 & 82.95 & $1 / 11 / 97$ & 92.59 & 92.08 \\
\hline $1 / 21 / 89$ & 82.12 & 81.98 & $9 / 19 / 91$ & 86.09 & 85.81 & $5 / 17 \overline{94}$ & 84.08 & 83.87 & $1 / 1297$ & 92.54 & 92.04 \\
\hline $1 / 22 / 89$ & 81.61 & 81.48 & $9 / 20 / 91$ & 85.92 & 85.65 & $5 / 18 / 94$ & 84.23 & 84.01 & $1 / 13 / 97$ & 92.69 & 92.18 \\
\hline $1 / 23 / 89$ & 81.57 & 81.45 & $9 / 21 / 91$ & $\begin{array}{l}84.65 \\
\end{array}$ & 84.42 & $5 / 19 / 94$ & $83.97 \mid$ & 83.76 & $1 / 14 / 97$ & 93.20 & 92.67 \\
\hline $1 / 24 / 89$ & 81.58 & 81.45 & $9 / 22 / 91$ & 83.22 & 83.04 & $5 / 20 / 94$ & 84.02 & 83.81 & $1 / 15 / 97$ & 93.46 & 92.92 \\
\hline $1 / 25 / 89$ & 81.61 & 81.48 & $9 / 23 / 91$ & 84.22 & 84.00 & $5 / 21 / 94$ & 83.04 & 82.86 & $1 / 16 / 97$ & 93.57 & 93.03 \\
\hline $1 / 26 / 89$ & 82.61 & 82.45 & $9 / 24 / 91$ & 86.95 & \begin{tabular}{|l|}
86.64 \\
\end{tabular} & $5 / 22 / 94$ & 82.90 & 82.73 & $1 / 17 / 97$ & 92.98 & 92.46 \\
\hline $1 / 27 / 89$ & 82.92 & 82.75 & $9 / 25 / 91$ & 86.21 & \begin{tabular}{|l|}
85.93 \\
\end{tabular} & $5 / 23 / 94$ & 83.35 & 83.16 & $1 / 18 / 97$ & 92.12 & 91.63 \\
\hline $1 / 28 / 89$ & 82.37 & 82.22 & $9 / 26 / 91$ & 86.60 & 86.30 & $5 / 24 / 94$ & 85.55 & 85.29 & $1 / 19 / 97$ & 90.97 & 90.52 \\
\hline $1 / 29 / 89$ & 81.74 & 81.61 & $9 / 27 / 91$ & 85.81 & 85.54 & $5 / 25 / 94$ & 85.80 & 85.53 & $1 / 20 / 97$ & 89.42 & 89.02 \\
\hline $1 / 30 / 89$ & 81.67 & 81.54 & $9 / 28 / 91$ & \begin{tabular}{|l|l|}
84.48 \\
\end{tabular} & 84.25 & $5 / 26 / 94$ & 84.23 & 84.01 & $1 / 21 / 97$ & 88.14 & 87.79 \\
\hline $1 / 31 / 89$ & 81.59 & 81.46 & $9 / 29 / 91$ & 84.11 & 83.90 & $5 / 27 / 94$ & 83.84 & 83.64 & $1 / 22 / 97$ & 87.59 & $\overline{87.26}$ \\
\hline $2 / 1 / 89$ & 81.54 & 81.42 & $9 / 30 / 91$ & 84.30 & 84.08 & $5 / 28 / 94$ & 82.75 & 82.58 & $1 / 23 / 97$ & 87.49 & 87.16 \\
\hline $2 \sqrt{2 / 89}$ & 81.56 & 81.44 & $10 / 1 / 91$ & $\begin{array}{l}85.18 \\
\end{array}$ & \begin{tabular}{|l|}
84.93 \\
\end{tabular} & $5 / 29 / 94$ & 82.38 & 82.23 & $1 / 24 / 97$ & 86.71 & 86.41 \\
\hline $2 / 3 / 89$ & 81.51 & 81.39 & $10 / 2 / 91$ & \begin{tabular}{|c|}
85.98 \\
\end{tabular} & 85.70 & $5 / 30 / 94$ & & & $1 / 25 / 97$ & 86.61 & 86.31 \\
\hline $2 / 4 / 89$ & 81.60 & 81.47 & $10 / 3 / 91$ & 86.57 & 86.27 & $5 / 31 / 94$ & & & $1 / 26 / 97$ & 85.10 & 84.85 \\
\hline $2 / 5 / 89$ & 81.62 & 81.49 & $10 / 4 / 91$ & 85.60 & 85.34 & $6 / 1 / 94$ & 83.53 & 83.34 & $1 / 27 / 97$ & 86.31 & 86.02 \\
\hline $2 / 6 / 89$ & 81.62 & 81.49 & $10 / 5 / 91$ & 85.04 & 84.80 & $6 / 2 / 94$ & 82.88 & 82.71 & $1 / 28 / 97$ & 86.97 & 86.66 \\
\hline $2 / 7 / 89$ & $\begin{array}{l}81.72 \\
\end{array}$ & 81.59 & $10 / 6 / 91$ & 84.69 & 84.46 & $6 / 3 / 94$ & 84.31 & 84.09 & $1 / 29 / 97$ & 86.19 & 85.91 \\
\hline $2 / 8 / 89$ & 81.80 & 81.67 & $10 / 7 / 91$ & \begin{tabular}{l|}
84.37 \\
\end{tabular} & 84.15 & $6 / 4 / 94$ & 83.82 & 83.62 & $1 / 30 / 97$ & 86.43 & 86.14 \\
\hline $219 / 89$ & 82.26 & 82.11 & $10 / 8 / 91$ & 84.90 & 84.66 & $6 / 5 / 94$ & 82.72 & 82.56 & $1 / 31 / 97$ & 87.89 & 87.55 \\
\hline $2 / 10 / 89$ & 82.67 & 82.51 & 10/9/91 & 86.55 & 86.25 & $6 / 6 / 94$ & 82.91 & 82.74 & $2 / 1 / 97$ & 87.57 & $\overline{87.24}$ \\
\hline $2 / 11 / 89$ & 82.29 & 82.14 & $10 / 10 / 91$ & 85.91 & 85.64 & $6 / 794$ & 83.62 & 83.42 & $2 / 2 / 97 \mid$ & 85.22 & 84.97 \\
\hline $2 / 12 / 89$ & \begin{tabular}{|l|}
81.74 \\
\end{tabular} & 81.61 & $10 / 11 / 91$ & 85.57 & 85.31 & 6/8/94 & 83.57 & 83.38 & $2 / 3 / 97$ & 85.18 & 84.93 \\
\hline $2 / 13 / 89$ & 81.57 & 81.45 & $10 / 12 / 91$ & 83.97 & 83.76 & 6/9/94 & 84.15 & 83.94 & $2 / 4 / 97$ & 86.49 & 86.20 \\
\hline $2 / 14 / 89$ & 81.54 & 81.42 & $10 / 13 / 91$ & 83.54 & 83.35 & $6 / 10 / 94$ & \begin{tabular}{|l|l|}
84.73 \\
\end{tabular} & 84.50 & $2 / 5 / 97$ & 87.78 & \begin{tabular}{|l|l|}
87.44 \\
\end{tabular} \\
\hline$=2 / 15 / 89$ & $=81.54$ & 81,42 & $=10 / 14 / 91$ & 83.67 & 83.47 & $=6 / 1 / 194$ & 83.71 & 83.51 & $=2 / 6997$ & 87.59 & 87.26 \\
\hline $2 / 16 / 89$ & & & $10 / 15 / 91$ & 84.13 & 83.92 & $6 / 12 / 94$ & 83.28 & 83.10 & $2 / 797$ & 87.62 & 87.25 \\
\hline $2 / 17 / 89$ & & & $10 / 16 / 91$ & 84.17 & 83.96 & $6 / 13 / 94$ & & & $2 / 8 / 97$ & 87.92 & 87.58 \\
\hline $2 / 18 / 89$ & & & $10 / 17 / 91$ & 83.67 & 83.47 & $6 / 14 / 94$ & & & 2/9/97| & 87.83 & 87.49 \\
\hline $2 / 19 / 89$ & & & $10 / 18 / 91$ & 83.00 & 82.83 & $6 / 15 / 94$ & 84.87 & 84.63 & $2 / 10 / 97$ & 87.99 & \begin{tabular}{|c|}
87.64 \\
\end{tabular} \\
\hline $2 / 20 / 89$ & & & $70 / 19 / 91$ & 82.60 & 82.44 & $6 / 16 / 94$ & 84.04 & 83.83 & $2 / 11 / 97$ & $87 . \overline{98}$ & 87.6 \\
\hline $2 / 21 / 89$ & & & $10 / 20 / 91$ & 82.50 & 82.34 & $6 / 17 / 94$ & 83.58 & 83.39 & $2 / 12 / 97$ & 87.85 & 87.5 \\
\hline $2 / 22 / 89$ & & & $10 / 21 / 91$ & 82.50 & 82.34 & $6 / 18 / 94$ & 83.21 & 83.03 & $2 / 13 / 97$ & 87.86 & 87.52 \\
\hline $2 / 23 / 89$ & & & $10 / 22 / 91$ & 82.03 & 81.89 & $6 / 19 / 94$ & 82.96 & 82.79 & $2 / 14 / 97$ & $\overline{89.20}$ & 88.81 \\
\hline
\end{tabular}


Appendix C (continued)

SR-TNX Estimated Historic Daily Mean Elevation

\begin{tabular}{|c|c|c|c|c|c|c|c|c|c|c|c|}
\hline Date & $\begin{array}{c}\text { SR- } \\
\text { Jackson } \\
\text { Elevation } \\
\text { (ft-msl) }\end{array}$ & $\begin{array}{c}\text { SR-TNX } \\
\text { Estimated } \\
\text { Elevation } \\
\text { (ft-msi) }\end{array}$ & Date & $\begin{array}{c}\text { SR- } \\
\text { Jackson } \\
\text { Elevation } \\
\text { (ft-msl) }\end{array}$ & $\begin{array}{c}\text { SR-TNX } \\
\text { Estimated } \\
\text { Elevation } \\
\text { (ft-msl) }\end{array}$ & Date & $\begin{array}{c}\text { SR- } \\
\text { Jackson } \\
\text { Elevation } \\
\text { (ft-msl) }\end{array}$ & $\begin{array}{c}\text { SR-TNX } \\
\text { Estimated } \\
\text { Elevation } \\
\text { (ft-msl) }\end{array}$ & Date & $\begin{array}{c}\text { SR- } \\
\text { Jackson } \\
\text { Elevation } \\
\text { (ft-msl) }\end{array}$ & \begin{tabular}{c|} 
SR-TNX \\
Estimated \\
Elevation \\
(ft-msi)
\end{tabular} \\
\hline $2 / 24 / 89$ & 89.88 & 89.47 & $10 / 23 / 91$ & 82.41 & 82.26 & $6 / 20 / 94$ & 83.30 & 83.12 & $2 / 15 / 97$ & 92.19 & 91.70 \\
\hline $2 / 25 / 89$ & 85.55 & 85.29 & $10 / 24 / 91$ & 83.45 & 83.26 & $6 / 21 / 94$ & 84.15 & 83.94 & $2 / 16 / 97$ & 93.56 & 93.02 \\
\hline $2 / 26 / 89$ & 83.87 & 83.67 & $10 / 25 / 91$ & 83.74 & 83.54 & $6 / 22 / 94$ & 85.61 & 85.35 & $2 / 17 / 97$ & 94.18 & 93.62 \\
\hline $2 / 27 / 89$ & 82.84 & 82.67 & $10 / 26 / 91$ & 84.26 & 84.04 & $6 / 23 / 94$ & 85.79 & 85.52 & $2 / 18 / 97$ & 93.41 & $\overline{92.88}$ \\
\hline $228 / 89$ & 82.45 & 82.29 & $10 / 27 / 91$ & 83.81 & 83.61 & $6 / 24 / 94$ & 84.75 & 84.52 & $2 / 19 / 97$ & 91.58 & 91.11 \\
\hline $3 / 1 / 89$ & 82.72 & 82.56 & $10 / 28 / 91$ & 83.88 & 83.68 & $6 / 25 / 94$ & 83.63 & 83.43 & $2 / 20 / 97$ & 90.18 & $\overline{89.76}$ \\
\hline $3 / 2 / 89$ & 85.89 & 85.62 & $10 / 29 / 91$ & 84.88 & 84.64 & $6 / 26 / 94$ & 82.94 & 82.77 & $2 / 21 / 97$ & 91.46 & 90.99 \\
\hline $3 / 3 / 89$ & 85.23 & 84.98 & $10 / 30 / 91$ & 85.11 & 84.86 & $6 / 27 / 94$ & 83.31 & 83.13 & $2 / 22 / 97$ & 93.07 & 92.55 \\
\hline $3 / 4 / 89$ & 84.17 & 83.96 & $10 / 31 / 91$ & 85.65 & 85.38 & $6 / 28 / 94$ & 85.56 & 85.30 & $2 / 23 / 97$ & 94.03 & 93.48 \\
\hline $3 / 5 / 89$ & 83.73 & 83.53 & $11 / 1 / 91$ & 85.11 & 84.86 & $6 / 29194$ & 90.57 & 90.13 & $2 / 24 / 97$ & 94.52 & 93.95 \\
\hline $3 / 6 / 89$ & 84.47 & 84.25 & $11 / 291$ & 85.58 & 85.32 & $6 / 30 / 94$ & 93.10 & 92.58 & $2 / 25 / 97$ & 94.56 & 93.99 \\
\hline $3 / 7 / 89$ & 84.65 & 84.42 & $11 / 3 / 1$ & 85.04 & 84.80 & $7 / 1 / 94$ & 94.51 & 93.94 & $2 / 26 / 97$ & 94.49 & 93.92 \\
\hline $3 / 8 / 89$ & 86.86 & 86.55 & $11 / 4 / 91$ & 84.26 & 84.04 & $7 / 2 / 94$ & 95.95 & $\begin{array}{l}95.33 \\
\end{array}$ & $2 / 27 / 97$ & 94.14 & 93.58 \\
\hline $3 / 9 / 89$ & 85.26 & 85.01 & $11 / 5 / 91$ & 86.14 & 85.86 & $7 / 3 / 94$ & 96.04 & 95.42 & $2 / 28 / 97$ & 93.90 & 93.35 \\
\hline $3 / 10 / 89$ & 83.27 & 83.09 & $11 / 6 / 91$ & 86.45 & 86.16 & $7 / 4 / 94$ & 94.81 & 94.23 & 3/1197 & 93.85 & 93.30 \\
\hline $3 / 11 / 89$ & 82.52 & 82.36 & $11 / 7 / 91$ & 86.70 & 86.40 & $7 / 5 / 94$ & 93.09 & 92.57 & $3 / 2 / 97$ & 93.89 & 93.34 \\
\hline $3 / 12 / 89$ & 82.07 & 81.93 & $11 / 8191$ & 86.31 & 86.02 & $7 / 6 / 94$ & 92.47 & 91.97 & $3 / 3 / 97$ & 93.86 & 93.31 \\
\hline $3 / 13 / 89$ & 81.98 & 81.84 & $11 / 9 / 91$ & 84.24 & 84.02 & $7 / 7 / 94$ & 93.36 & 92.83 & 3/4/97 & 93.59 & 93.05 \\
\hline $3 / 14 / 89$ & 81.99 & 81.85 & $11 / 10 / 91$ & 85.90 & 85.63 & $7 / 8 / 94$ & 93.84 & 93.29 & $3 / 5 / 97$ & 93.46 & 92.92 \\
\hline $3 / 15 / 89$ & 82.38 & 82.23 & $11 / 11 / 91$ & 84.98 & 84.74 & $7 / 9 / 94$ & 94.53 & 93.96 & $3 / 6 / 97$ & 93.68 & 93.14 \\
\hline $3 / 16 / 89$ & 82.11 & 81.97 & $11 / 12 / 91$ & 86.12 & 85.84 & $7 / 10 / 94$ & 94.02 & 93.47 & $3 / 7 / 97$ & 94.12 & 93.56 \\
\hline $3 / 17 / 89$ & 82.14 & 82.00 & $11 / 13 / 91$ & 85.38 & 85.12 & $7 / 11 / 94$ & 91.95 & 91.47 & $3 / 8 / 97$ & 94.66 & 94.08 \\
\hline $3 / 18 / 89$ & 82.40 & 82.25 & $11 / 14 / 91$ & 85.32 & 85.07 & $7 / 12 / 94$ & 89.03 & 88.65 & $3 / 9 / 97$ & 95.03 & 94.44 \\
\hline $3 / 19 / 89$ & 82.01 & 81.87 & $11 / 15 / 91$ & 85.03 & 84.79 & $7 / 13 / 94$ & 86.73 & 86.43 & $3 / 10 / 97$ & 95.26 & 94.66 \\
\hline $3 / 20 / 89$ & 81.88 & 81.74 & $11 / 16 / 91$ & 84.60 & 84.37 & $7 / 14 / 94$ & 85.26 & 85.01 & $3 / 11 / 97$ & 95.38 & 94.78 \\
\hline $3 / 21 / 89$ & 81.97 & 81.83 & $11 / 17 / 91$ & 84.38 & 84.16 & $7 / 15 / 94$ & 86.54 & 86.24 & $3 / 12 / 97$ & 95.38 & $\overline{94.78}$ \\
\hline $3 / 22 / 89$ & 82.08 & 81.94 & $11 / 18 / 91$ & 83.64 & 83.44 & $7 / 16 / 94$ & 87.85 & 87.51 & $3 / 13 / 97$ & 94.82 & 94.24 \\
\hline $3 / 23 / 89$ & 83.24 & 83.06 & $11 / 19 / 91$ & 84.83 & 84.59 & $7 / 17 / 94$ & 88.63 & 88.26 & $3 / 14 / 97$ & 93.53 & 92.99 \\
\hline $3 / 24 / 89$ & 87.95 & 87.61 & $11 / 20 / 91$ & 84.19 & 83.97 & $7 / 18 / 94$ & 89.00 & 88.62 & $3 / 15 / 97$ & 92.65 & 92.14 \\
\hline $3 / 25 / 89$ & 91.67 & 91.20 & $11 / 21 / 91$ & 83.73 & 83.53 & $7 / 19 / 94$ & 89.45 & 89.05 & $3 / 16 / 97$ & 91.66 & 91.19 \\
\hline $3 / 26 / 89$ & 91.03 & 90.58 & $11 / 22 / 91$ & 83.98 & 83.77 & $7 / 20 / 94$ & 89.36 & 88.97 & $3 / 17 / 97$ & 90.83 & 90.39 \\
\hline $3 / 27 / 89$ & 86.38 & 86.09 & $11 / 23 / 91$ & 84.13 & 83.92 & $7 / 21 / 94$ & 89.56 & 89.16 & $3 / 18 / 97$ & 89.31 & 88.92 \\
\hline $3 / 28 / 89$ & 83.69 & 83.49 & $11 / 24 / 91$ & 83.57 & 83.38 & $7 / 22194$ & 89.14 & 88.75 & $3 / 19197$ & 88.55 & 88.18 \\
\hline $3 / 29 / 89$ & 83.10 & 82.92 & $11 / 25 / 91$ & 83.58 & 83.39 & $7 / 23 / 94$ & 87.50 & 87.17 & $3 / 20 / 97$ & 88.54 & 88.17 \\
\hline $3 / 30 / 89$ & 82.74 & 82.57 & $11 / 26 / 91$ & 85.45 & 85.19 & $7 / 24 / 94$ & 87.41 & 87.08 & $3 / 21 / 97$ & 88.77 & 88.40 \\
\hline $3 / 31 / 89$ & 82.82 & 82.65 & $11 / 27 / 91$ & 86.95 & 86.64 & $7 / 25194$ & 86.96 & 86.65 & $3 / 22 / 97$ & 89.13 & 88.74 \\
\hline $4 / 1 / 89$ & 83.19 & 83.01 & $11 / 28 / 91$ & 86.65 & 86.35 & $7 / 26 / 94$ & 85.97 & 85.69 & $3 / 23 / 97$ & 87.23 & 86.91 \\
\hline $4 / 2 / 89$ & 82.77 & 82.60 & $11 / 29 / 91$ & 83.78 & 83.58 & 7/27/94 & 84.61 & 84.38 & $3 / 24 / 97$ & 86.96 & 86.65 \\
\hline $4 / 3 / 89$ & & & $11 / 30 / 91$ & 82.79 & 82.62 & $7 \sqrt{28194}$ & 84.49 & 84.26 & $3 / 25 / 97$ & 89.49 & 89.09 \\
\hline $4 / 4 / 89$ & 81.92 & 81.78 & $12 / 1 / 91$ & 82.90 & 82.73 & $7 / 29 / 94$ & 84.54 & 84.31 & $3 / 26 / 97$ & 91.23 & 90.77 \\
\hline $4 / 5 / 89$ & 81.85 & 81.72 & $12 / 2 / 91$ & 83.14 & 82.96 & $7 / 30 / 94$ & 87.36 & 87.04 & $3 / 27 / 97$ & 91.59 & 91.12 \\
\hline $4 / 6 / 89$ & $81.8 \mathrm{r}$ & 81.68 & $12 / 3 / 91$ & 84.69 & 84.46 & $7 / 31 / 94$ & 86.59 & 86.29 & $3 / 28 / 97$ & 91.99 & 91.51 \\
\hline $4 / 7 / 89$ & 81.80 & 81.67 & $12 / 4 / 91$ & 84.73 & 84.50 & $8 / 1 / 94$ & 85.02 & 84.78 & $3 / 29 / 97$ & 92.04 & 91.55 \\
\hline
\end{tabular}


Appendix C (continued)

SR-TNX Estimated Historic Daily Mean Elevation

\begin{tabular}{|c|c|c|c|c|c|c|c|c|c|c|c|}
\hline Date & $\begin{array}{c}\text { SR- } \\
\text { Jackson } \\
\text { Elevation } \\
\text { (ft-msl) } \\
\end{array}$ & $\begin{array}{c}\text { SR-TNX } \\
\text { Estimated } \\
\text { Elevation } \\
\text { (ft-msl) }\end{array}$ & Date & \begin{tabular}{|c|} 
SR- \\
Jackson \\
Elevation \\
(ft-msl) \\
\end{tabular} & $\begin{array}{c}\text { SR-TNX } \\
\text { Estimated } \\
\text { Elevation } \\
\text { (ft-msl) }\end{array}$ & Date & \begin{tabular}{|c|} 
SR- \\
Jackson \\
Elevation \\
(ft-msl) \\
\end{tabular} & $\begin{array}{l}\text { SR-TNX } \\
\text { Estimated } \\
\text { Elcvation } \\
\text { (ft-msl) }\end{array}$ & Date & $\begin{array}{c}\text { SR- } \\
\text { Jackson } \\
\text { Elevation } \\
\text { (ft-msl) }\end{array}$ & $\begin{array}{c}\text { SR-TNX } \\
\text { Estimated } \\
\text { Elcvation } \\
\text { (ft-msl) }\end{array}$ \\
\hline $4 / 8 / 89$ & 82.60 & 82.44 & $12 / 5 / 91$ & 84.94 & $84 . \overline{70}$ & $8 / 2 / 94$ & 84.92 & 84.68 & $3 / 30 / 97$ & 89.34 & 88.95 \\
\hline $4 / 9 / 89$ & 82.80 & 82.63 & $12 / 6 / 91$ & 84.52 & 84.29 & $8 / 3 / 94$ & 86.00 & 85.72 & $3 / 31 / 97$ & 86.58 & 86.28 \\
\hline $4 / 10 / 89$ & 84.90 & 84.66 & $12 / 7 / 91$ & 83.00 & $82 . \overline{83}$ & $8 / 4 / 94$ & 86.38 & 86.09 & $4 / 1 / 97$ & 85.69 & 85.42 \\
\hline $4 / 11 / 89$ & 88.62 & 88.25 & $12 / 8 / 91$ & 83.12 & $82 . \overline{94}$ & $8 / 5 / 94$ & 86.73 & 86.43 & $4 / 2 / 97$ & 86.00 & 85.72 \\
\hline $4 / 12 / 89$ & 88.62 & 88.25 & $12 / 9 / 91$ & 83.47 & 83.28 & $8 / 6 / 94$ & 86.45 & 86.16 & $4 / 3 / 97$ & 90.03 & 89.61 \\
\hline $4 / 13 / 89$ & 86.39 & 86.10 & $12 / 10 / 91$ & 83.55 & 83.36 & $8 / 7 / 94$ & 84.76 & 84.53 & $4 / 4 / 97$ & 91.40 & 90.94 \\
\hline $4 / 14 / 89$ & 83.54 & 83.35 & $12 / 11 / 91$ & 83.31 & 83.13 & $8 / 8 / 94$ & 85.04 & 84.80 & $4 / 5 / 97$ & 89.96 & 89.55 \\
\hline $4 / 15 / 89$ & 82.94 & 82.77 & $12 / 2 / 91$ & 83.08 & 82.90 & $8 / 9 / 94$ & 84.84 & 84.60 & $4 / 6 / 97$ & 87.10 & 86.78 \\
\hline $4 / 16 / 89$ & $8 \overline{5.73}$ & 85.46 & $12 / 13 / 91$ & 82.86 & 82.69 & $8 / 10 / 94$ & 86.56 & 86.26 & $4 / 7 / 97$ & 86.34 & 86.05 \\
\hline $4 / 17 / 89$ & 90.04 & 89.62 & $12 / 14 / 91$ & 82.80 & 82.63 & $8 / 11 / 94$ & 86.52 & 86.22 & $4 / 8 / 97$ & 88.14 & 87.79 \\
\hline $4 / 18 / 89$ & 89.95 & 89.54 & $12 / 15 / 91$ & 83.11 & 82.93 & $8 / 12 / 94$ & 86.43 & 86.14 & $4 \times 197$ & 89.63 & 89.23 \\
\hline $4 / 19 / 89$ & 84.69 & 84.46 & $12 / 16 / 91$ & 84.45 & 84.23 & $8 / 13 / 94$ & 86.01 & 85.73 & 4/10/97 & 90.14 & 89.72 \\
\hline $4 / 20 / 89$ & 82.96 & 82.79 & $12 / 17 / 91$ & 85.67 & 85.40 & $8 / 14 / 94$ & 84.63 & 84.40 & $4 / 11 / 97$ & 90.53 & 90.10 \\
\hline $4 / 21 / 89$ & 83.25 & 83.07 & $12 / 18 / 91$ & 87.87 & 87.53 & $8 / 15 / 94$ & 84.08 & 83.87 & $4 / 12 / 97$ & 91.22 & 90.76 \\
\hline $4 / 22 / 89$ & 82.75 & 82.58 & $12 / 19 / 91$ & 88.73 & 88.36 & $8 / 16 / 94$ & 85.48 & 85.22 & $4 / 13 / 97$ & 88.35 & 87.99 \\
\hline $4 / 23 / 89$ & 82.16 & 82.01 & $12 / 20 / 91$ & 88.29 & 87.93 & $8 / 17 / 94$ & 88.03 & 87.68 & 4/14/97 & 85.20 & 84.95 \\
\hline $4 / 24 / 89$ & 82.07 & 81.93 & $12 / 21 / 91$ & 86.03 & 85.75 & $8 / 18 / 94$ & 91.68 & 91.21 & $4 / 15 / 97$ & 85.27 & 85.02 \\
\hline $4 / 25 / 89$ & 82.39 & 82.24 & $12 / 22 / 91$ & 83.68 & 83.48 & $8 / 19 / 94$ & 93.77 & 93.22 & $4 / 16 / 97$ & 84.83 & 84.59 \\
\hline $4 / 26 / 89$ & 82.41 & 82.26 & $12 / 23 / 91$ & 83.69 & 83.49 & $8 / 20 / 94$ & 95.26 & 94.66 & $4 / 17 / 97$ & 84.52 & 84.29 \\
\hline $4 / 27 / 89$ & 82.11 & 81.97 & $12 / 24 / 91$ & 83.96 & 83.75 & $8 / 21 / 94$ & 95.84 & 95.22 & $4 / 18 / 97$ & 84.30 & 84.08 \\
\hline $4 / 28 / 89$ & 82.09 & 81.95 & $12 / 25 / 91$ & 84.38 & 84.16 & $8 / 22 / 94$ & 95.95 & 95.33 & $4 / 19 / 97$ & 84.43 & 84.21 \\
\hline $4 / 29 / 89$ & 81.86 & 81.73 & $12 / 26 / 91$ & 84.73 & 84.50 & $8 / 23 / 94$ & 96.07 & 95.44 & $4 / 20 / 97$ & 84.39 & 84.17 \\
\hline $4 / 30 / 89$ & 81.70 & 81.57 & $12 / 27 / 91$ & 85.06 & 84.81 & $8 / 24 / 94$ & 96.14 & 95.51 & $4 / 21 / 97$ & 83.77 & 83.57 \\
\hline $5 / 1 / 89$ & 81.78 & 81.65 & $12 / 28 / 91$ & 84.92 & 84.68 & $8 / 25 / 94$ & 96.08 & 95.45 & $4 / 22 / 97$ & 83.98 & 83.77 \\
\hline $5 / 2 / 89$ & 82.24 & 82.09 & $12 / 29 / 91$ & 85.90 & 85.63 & $8 / 26 / 94$ & 96.02 & 95.40 & $4 / 23 / 97$ & 85.25 & 85.00 \\
\hline $5 / 3 / 89$ & 82.72 & 82.56 & $12 / 30 / 91$ & 86.06 & 85.78 & $8 / 27 / 94$ & 95.99 & 95.37 & $4 / 24 / 97$ & 87.74 & 87.40 \\
\hline $5 / 4 / 89$ & 83.11 & 82.93 & $12 / 31 / 91$ & 86.41 & 86.12 & $8 / 28 / 94$ & 95.70 & 95.09 & $4 / 25 / 97$ & 91.22 & 90.76 \\
\hline $5 / 5 / 89$ & 82.75 & 82.58 & $1 / 1 / 92$ & 86.32 & 86.03 & $8 / 29 / 94$ & 95.00 & 94.41 & $4 / 26 / 97$ & 92.10 & 91.61 \\
\hline $5 / 6 / 89$ & 82.38 & 82.23 & $1 / 2 / 92$ & 85.71 & 85.44 & $8 / 30 / 94$ & 94.45 & 93.88 & $4 / 27 / 97$ & 90.43 & 90.00 \\
\hline $5 / 7 / 89$ & 82.09 & 81.95 & $1 / 3 / 92$ & 85.90 & 85.63 & $8 / 31 / 94$ & 94.53 & 93.96 & $4 / 28 / 97$ & 88.46 & 88.10 \\
\hline $5 / 8 / 89$ & 81.88 & 81.74 & $1 / 4 / 92$ & 85.22 & 84.97 & $9 / 1 / 94$ & 94.56 & 93.99 & $4 / 29 / 97$ & 88.28 & 87.92 \\
\hline 5/9/89 & 81.90 & 81.76 & $1 / 5 / 92$ & 85.64 & 85.37 & $9 / 2 / 94$ & 94.34 & 93.77 & $4 / 30 / 97$ & 91.29 & 90.83 \\
\hline $5 / 10 / 89$ & 82.26 & 82.11 & $1 / 6 / 92$ & 84.61 & 84.38 & $9 / 3 / 94$ & 94.26 & 93.70 & $5 / 1 / 97$ & 93.03 & 92.51 \\
\hline $5 / 11 / 89$ & 83.97 & 83.76 & $1 / 7 / 92$ & 86.52 & 86.22 & 9/4/94 & 93.44 & 92.91 & $5 / 2 / 97$ & 93.73 & 93.19 \\
\hline $5 / 12 / 89$ & 85.46 & 85.20 & $1 / 8 / 92$ & 87.08 & 86.77 & $9 / 5 / 94$ & 91.17 & 90.71 & $5 / 3197$ & 93.85 & 93.30 \\
\hline $5 / 13 / 89$ & 82.96 & 82.79 & $1 / 9192$ & 86.19 & 85.91 & $9 / 6 / 94$ & 89.49 & 89.09 & $5 / 4 / 97$ & 93.15 & 92.63 \\
\hline $5 / 14 / 89$ & 82.06 & 81.92 & $1 / 10 / 92$ & 85.04 & 84.80 & $9 / 7 / 94$ & 89.30 & 88.91 & $5 / 5 / 97$ & 92.39 & 91.89 \\
\hline $5 / 15 / 89$ & 82.01 & 81.87 & $1 / 11 / 92$ & 85.64 & 85.37 & $9 / 8 / 94$ & 88.26 & 87.90 & $5 / 6 / 97$ & 91.95 & 91.47 \\
\hline $5 / 16 / 89$ & 82.36 & 82.21 & $1 / 12 / 92$ & 85.74 & 85.47 & $9 / 9 / 94$ & 86.08 & 85.80 & $5 / 7 / 97$ & 91.85 & 91.37 \\
\hline $5 / 17 / 89$ & 82.29 & 82.14 & $1 / 13 / 92$ & 84.19 & 83.97 & $9 / 10 / 94$ & 86.25 & 85.96 & $5 / 8 / 97$ & 91.53 & 91.06 \\
\hline $5 / 18 / 89$ & 82.09 & 81.95 & $1 / 14 / 92$ & 86.87 & 86.56 & $9 / 11 / 94$ & 85.96 & 85.68 & $5 / 9 / 97$ & 91.27 & 90.81 \\
\hline $5 / 19 / 89$ & 82.47 & 82.31 & I/15/92 & 87.75 & 87.41 & $9 / 12 / 94$ & 84.85 & 84.61 & $5 / 10 / 97$ & 90.82 & 90.38 \\
\hline $5 / 20 / 89$ & 82.26 & 82.11 & $1 / 16 / 92$ & 87.15 & 86.83 & $9 / 13 / 94$ & 84.66 & 84.43 & $5 / 11 / 97$ & 88.24 & 87.89 \\
\hline
\end{tabular}


Appendix C (continued)

$\underline{\text { SR-TNX Estimated Historic Daily Mean Elevation }}$

\begin{tabular}{|c|c|c|c|c|c|c|c|c|c|c|c|}
\hline Date & \begin{tabular}{|c|} 
SR- \\
Jackson \\
Elevation \\
(ft-msl)
\end{tabular} & \begin{tabular}{|c|} 
SR-TNX \\
Estimated \\
Elcvation \\
(ft-msl)
\end{tabular} & Date & \begin{tabular}{|c|} 
SR- \\
Jackson \\
Elevation \\
(ft-ms!) \\
\end{tabular} & \begin{tabular}{c|} 
SR-TNX \\
Estimated \\
Elevation \\
(ft-msl)
\end{tabular} & Date & \begin{tabular}{|c|} 
SR- \\
Jackson \\
Elevation \\
(ft-msi) \\
\end{tabular} & \begin{tabular}{|c|} 
SR-TNXX \\
Estimated \\
Elevation \\
(ft-msl)
\end{tabular} & Date & $\begin{array}{c}\text { SR- } \\
\text { Jackson } \\
\text { Elevation } \\
\text { (ft-msl) }\end{array}$ & $\begin{array}{l}\text { SR-TNX } \\
\text { Estimated } \\
\text { Elevation } \\
\text { (ft-msl) }\end{array}$ \\
\hline $5 / 21 / 89$ & 81.88 & 81.74 & $1 / 17 / 92$ & 86.10 & 85.82 & $9 / 14 / 94$ & & & $5 / 12 / 97$ & \begin{tabular}{|r|}
85.55 \\
\end{tabular} & 85.29 \\
\hline $5 / 22 / 89$ & 81.77 & 81.64 & $1 / 18 / 92$ & 85.29 & 85.04 & $9 / 15 / 94$ & & & $5 / 13 / 97$ & 84.55 & 84.32 \\
\hline $5 / 23 / 89$ & 81.71 & 81.58 & $1 / 19 / 92$ & 85.24 & 84.99 & $9 / 16 / 94$ & & & $5 / 14 / 97$ & 86.35 & 86.06 \\
\hline $5 / 24 / 89$ & 81.80 & 81.67 & $1 / 20 / 92$ & 85.75 & 85.48 & $9 / 17 / 94$ & & & $5 / 15 / 97$ & 87.28 & 86.96 \\
\hline $5 / 25 / 89$ & 81.80 & $81.67 \mid$ & $1 / 21 / 92$ & 86.96 & $86.65 \mid$ & $9 / 18 / 94$ & & & $5 / 16 / 97$ & 88.17 & 87.82 \\
\hline $5 / 26 / 89$ & 81.69 & 81.56 & $1 / 22 / 92$ & 86.85 & $86.54 \mid$ & $9 / 19 / 94$ & & & $5 / 17 / 97$ & 87.18 & 86.86 \\
\hline $5 / 27 / 89$ & 81.71 & 81.58 & $1 / 23 / 92$ & 86.74 & 86.44 & $9 / 20 / 94$ & & & $5 / 18 / 97$ & 85.71 & 85.44 \\
\hline $5 / 28 / 89$ & 81.52 & 81.40 & $1 / 24 / 92$ & 86.86 & 86.55 & $9 / 21 / 94$ & 85.73 & 85.46 & $5 / 19 / 97$ & 84.28 & 84.06 \\
\hline $5 / 29 / 89$ & 81.37 & 81.25 & $1 / 25 / 92$ & 85.63 & 85.37 & $9 / 22 / 94$ & 86.93 & 86.62 & $5 / 20 / 97$ & 84.94 & 84.70 \\
\hline $5 / 30 / 89$ & 81.33 & 81.21 & $1 / 26 / 92$ & 86.04 & 85.76 & $9 / 23 / 94$ & 87.30 & 86.98 & $5 / 21 / 97$ & 86.26 & 85.97 \\
\hline $5 / 31 / 89$ & 81.39 & 81.27 & $1 / 27 / 92$ & 85.24 & 84.99 & $9 / 24 / 94$ & 87.09 & 86.77 & $5 / 22 / 97$ & 85.95 & 85.67 \\
\hline $6 / 1 / 89$ & 81.49 & 81.37 & $1 / 28 / 92$ & 86.02 & 85.74 & $9 / 25 / 94$ & 85.28 & 85.03 & $5 / 23 / 97$ & 85.52 & 85.26 \\
\hline $6 / 2 / 89$ & 81.44 & 81.32 & $1 / 29 / 92$ & 85.81 & 85.54 & $9 / 26 / 94$ & 84.17 & 83.96 & $5 / 24 / 97$ & 85.22 & 84.97 \\
\hline $6 / 3 / 89$ & 81.38 & 81.26 & $1 / 30 / 92$ & $85.67 \mid$ & 85.40 & $9 / 27 / 94$ & 85.98 & 85.70 & $5 / 25 / 97$ & 83.87 & 83.67 \\
\hline $6 / 4 / 89$ & 81.30 & 81.18 & $1 / 31 / 92$ & 85.85 & 85.58 & $9 / 28 / 94$ & 87.29 & 86.97 & $5 / 26 / 97$ & 83.53 & $\overline{83.34}$ \\
\hline $6 / 5 / 89$ & 81.31 & 81.19 & $2 / 1 / 92$ & 84.55 & 84.32 & $9 / 29 / 94$ & 87.74 & 87.40 & $5 / 27 / 97$ & 84.39 & 84.17 \\
\hline $6 / 6 / 89$ & 81.40 & 81.28 & $2 / 2792$ & 84.37 & 84.15 & $9 / 30 / 94$ & 87.46 & 87.13 & $5 / 28 / 97$ & 85.19 & 84.94 \\
\hline $6 / 789$ & 81.50 & 81.38 & $2 / 3 / 92$ & 84.08 & $\begin{array}{l}83.87 \\
\end{array}$ & $10 / 1 / 94$ & & & $5 / 29197$ & 85.43 & 85.17 \\
\hline 6/8/89 & 81.43 & 81.31 & $2 / 4 / 92$ & 84.57 & 84.34 & $10 / 2 / 94$ & 85.64 & 85.37 & $5 / 30 / 97$ & 85.52 & 85.26 \\
\hline $6 / 9 / 89$ & 81.84 & \begin{tabular}{|l|}
81.71 \\
\end{tabular} & $2 / 5 / 92$ & 83.79 & 83.59 & $10 / 3 / 94$ & 85.23 & 84.98 & $5 / 31 / 97$ & 85.83 & 85.56 \\
\hline $6 / 10 / 89$ & 82.55 & 82.39 & $2 / 6 / 92$ & 83.25 & 83.07 & $10 / 4 / 94$ & 85.58 & 85.32 & 6/1/97 & 85.13 & 84.88 \\
\hline $6 / 11 / 89$ & 82.47 & 82.31 & $2 / 792$ & 83.76 & 83.56 & $10 / 5 / 94$ & & & $6 / 2 / 97$ & 84.00 & 83.79 \\
\hline $6 / 12 / 89$ & 82.12 & 81.98 & $2 / 8 / 92$ & 83.45 & 83.26 & $10 / 6 / 94$ & & & $6 / 3 / 97$ & 83.79 & 83.59 \\
\hline $6 / 13 / 89$ & 81.69 & 81.56 & $2 / 9 / 92$ & 83.23 & 83.05 & $10 / 7 / 94$ & 85.04 & 84.80 & $6 / 4 / 97$ & \begin{tabular}{|l|}
83.98 \\
\end{tabular} & 83.77 \\
\hline $6 / 14 / 89$ & 81.50 & 81.38 & $2 / 10 / 92$ & 83.16 & 82.98 & $10 / 8 / 94$ & 84.91 & \begin{tabular}{|c|}
84.67 \\
\end{tabular} & $6 / 5197 \mid$ & 83.80 & 83.60 \\
\hline $6 / 15 / 89$ & 81.41 & 81.29 & $2 / 11 / 92$ & 84.70 & 84.47 & $10 / 9 / 94$ & 84.58 & 84.35 & $6 / 6 / 97$ & 83.79 & 83.59 \\
\hline $6 / 16 / 89$ & 81.72 & 81.59 & $2 / 12 / 92$ & 85.31 & 85.06 & $10 / 10 / 94$ & 84.70 & 84.47 & $6 / 7197$ & 83.78 & 83.58 \\
\hline $6 / 17 / 89$ & 82.09 & 81.95 & $2 / 13 / 92$ & 85.27 & 85.02 & $10 / 11 / 94$ & 85.71 & 85.44 & $6 / 8 / 97$ & $83.49 \mid$ & 83.30 \\
\hline $6 / 18 / 89$ & 81.92 & 81.78 & $2 / 14 / 92$ & 84.11 & 83.90 & $10 / 12 / 94$ & $87.01 \mid$ & 86.70 & 6/9197 & 83.58 & 83.39 \\
\hline $6 / 19 / 89$ & 81.65 & 81.52 & $2 / 15 / 92$ & 83.33 & 83.14 & $10 / 13 / 94$ & 89.14 & 88.75 & $6 / 10 / 97$ & 87.36 & 87.04 \\
\hline $6 / 20 / 89$ & 82.05 & 81.91 & $2 / 16992$ & 84.31 & 84.09 & $10 / 14 / 94$ & 90.95 & 90.50 & $6 / 11 / 97$ & 90.17 & 89.75 \\
\hline $6 / 21 / 89$ & 82.80 & 82.63 & $2 / 17 / 92$ & 84.87 & 84.63 & $10 / 15 / 94$ & 92.32 & 91.82 & $6 / 12197$ & 90.97 & 90.52 \\
\hline $6 / 22 / 89$ & 86.54 & 86.24 & $2 / 18 / 92$ & 86.66 & 86.36 & $10 / 16 / 94$ & 93.61 & 93.07 & $6 / 13 / 97$ & 91.73 & 91.25 \\
\hline $6 / 23 / 89$ & 88.28 & 87.92 & $2 / 19 / 92$ & 86.98 & 86.67 & $10 / 17 / 94$ & 94.60 & 94.03 & $6 / 14 / 97$ & 92.23 & 91.74 \\
\hline $6 / 24 / 89$ & 85.22 & 84.97 & $2 / 20 / 92$ & 86.72 & 86.42 & $10 / 18 / 94$ & 95.07 & 94.48 & $6 / 15 / 97$ & 90.59 & 90.15 \\
\hline $6 / 25 / 89$ & 83.78 & 83.58 & $2 / 21 / 92$ & 85.93 & 85.65 & $10 / 19 / 94$ & 94.73 & 94.15 & $6 / 16 / 97$ & 86.20 & 85.92 \\
\hline $6 / 26 / 89$ & 82.56 & 82.40 & $2 / 22 / 92$ & 86.14 & 85.86 & $10 / 20 / 94$ & 94.16 & 93.60 & $6 / 17 / 97$ & 84.53 & 84.30 \\
\hline $6 / 27 / 89$ & 82.01 & 81.87 & $2 / 23 / 92$ & 86.54 & 86.24 & $10 / 21 / 94$ & 93.60 & 93.06 & $6 / 18 / 97$ & 86.47 & 86.18 \\
\hline $6 / 28 / 89$ & 82.06 & 81.92 & $2 / 24 / 92$ & $\begin{array}{l}87.28 \\
\end{array}$ & 86.96 & $10 / 22 / 94$ & 92.88 & 92.36 & $6 / 19 / 97$ & 87.39 & 87.06 \\
\hline $6 / 29 / 89$ & 81.92 & 81.78 & $2 / 25 / 92$ & 86.03 & 85.75 & $10 / 23 / 94$ & 93.10 & 92.58 & $6 / 20 / 97$ & 87.25 & 86.93 \\
\hline $6 / 30 / 89$ & 81.89 & 81.75 & $2 / 26 / 92$ & 88.89 & 88.51 & $10 / 24 / 94$ & 93.60 & 93.06 & $6 / 21 / 97$ & 86.82 & 86.51 \\
\hline $7 / 1 / 89$ & 82.02 & 81.88 & $2 / 2792$ & 90.94 & 90.49 & $10 / 25 / 94$ & 93.95 & 93.40 & $6 / 22 / 97$ & 86.90 & 86.59 \\
\hline $7 / 2 / 89$ & 81.82 & 81.69 & $2 / 28 / 92$ & 90.71 & 90.27 & $10 / 26 / 94$ & 93.99 & 93.44 & $6 / 23 / 97$ & 86.46 & 86.17 \\
\hline
\end{tabular}


Appendix C (continued)

SR-TNX Estimated Historic Daily Mean Elevation

\begin{tabular}{|c|c|c|c|c|c|c|c|c|c|c|c|}
\hline Date & $\begin{array}{c}\text { SR- } \\
\text { Jackson } \\
\text { Elevation } \\
\text { (ft-msl) }\end{array}$ & $\begin{array}{l}\text { SR-TNX } \\
\text { Estimated } \\
\text { Elevation } \\
\text { (ft-msl) }\end{array}$ & Date & $\begin{array}{c}\text { SR- } \\
\text { Jackson } \\
\text { Elevation } \\
\text { (ft-ms!) }\end{array}$ & $\begin{array}{l}\text { SR-TNX } \\
\text { Estimated } \\
\text { Elevation } \\
\text { (ft-msl) }\end{array}$ & Date & $\begin{array}{c}\text { SR- } \\
\text { Jackson } \\
\text { Elevation } \\
\text { (ft-msl) }\end{array}$ & $\begin{array}{c}\text { SR-TNX } \\
\text { Estimated } \\
\text { Elevation } \\
\text { (fi-msl) }\end{array}$ & Date & $\begin{array}{c}\text { SR- } \\
\text { Jackson } \\
\text { Elevation } \\
\text { (ft-msl) }\end{array}$ & \begin{tabular}{c||} 
SR-TNX \\
Estimated \\
Elevation \\
(ft-msl)
\end{tabular} \\
\hline $7 / 3 / 89$ & 81.70 & 81.57 & $2 / 29 / 92$ & 87.48 & 87.15 & $10 / 27 / 94$ & 93.94 & 93.39 & $6 / 24 / 97$ & 86.63 & 86.33 \\
\hline $7 / 4 / 89$ & 81.78 & 81.65 & $3 / 1 / 92$ & 86.00 & 85.72 & $10 / 28 / 94$ & 93.72 & 93.18 & $6 / 25197$ & 86.81 & 86.50 \\
\hline $7 / 5 / 89$ & 83.73 & 83.53 & $3 / 2 / 92$ & 86.31 & 86.02 & $10 / 29 / 94$ & 92.41 & 91.91 & $6 / 26 / 97$ & 86.82 & 86.51 \\
\hline $7 / 6 / 89$ & & & $3 / 3 / 92$ & 86.65 & 86.35 & $10 / 30 / 94$ & 90.38 & 89.95 & $6 / 27 / 97$ & 87.30 & 86.98 \\
\hline $7 / 7 / 89$ & & & $3 / 4 / 92$ & 86.49 & 86.20 & $10 / 31 / 94$ & 87.73 & 87.39 & $6 / 28 / 97$ & 87.67 & 87.33 \\
\hline 7/8/89 & & & $3 / 5 / 92$ & 85.65 & 85.38 & $11 / 1 / 94$ & 89.75 & 89.34 & $6 / 29 / 97$ & 86.31 & 86.02 \\
\hline $7 / 9 / 89$ & & & $3 / 6 / 92$ & 84.94 & 84.70 & $11 / 2 / 94$ & 91.35 & 90.89 & $6 / 30 / 97$ & 85.31 & 85.06 \\
\hline $7 / 10 / 89$ & 87.96 & 87.61 & $3 / 7 / 92$ & 87.96 & 87.61 & $11 / 3 / 94$ & 91.98 & 91.50 & $7 / 1 / 97$ & 85.65 & 85.38 \\
\hline $7 / 11 / 89$ & 83.03 & $82 . \overline{85}$ & $3 / 8 / 92$ & 91.67 & 91.20 & $11 / 4 / 94$ & 92.05 & 91.56 & $7 / 2 / 97$ & 86.42 & 86.13 \\
\hline $7 / 12 / 89$ & 82.48 & $82 . \overline{32}$ & $3 / 9 / 92$ & 92.45 & 91.95 & $11 / 5 / 94$ & 91.94 & 91.46 & $7 / 3 / 97$ & 86.35 & 86.06 \\
\hline $7 / 13 / 89$ & 82.97 & 82.80 & $3 / 10 / 92$ & 91.30 & 90.84 & $11 / 6 / 94$ & 90.59 & 90.15 & $7 / 4 / 97$ & 86.16 & 85.88 \\
\hline $7 / 14 / 89$ & 84.01 & 83.80 & $3 / 11 / 92$ & 88.13 & 87.78 & $11 / 7 / 94$ & 88.88 & 88.50 & $7 / 5 / 97$ & 85.22 & 84.97 \\
\hline $7 / 15 / 89$ & 84.04 & $83 . \overline{83}$ & $3 / 12 / 92$ & 86.49 & 86.20 & $11 / 8 / 94$ & 89.12 & 88.73 & $7 / 6197$ & 84.37 & 84.15 \\
\hline $7 / 16 / 89$ & 83.21 & 83.03 & $3 / 13 / 92$ & 86.26 & 85.97 & $11 / 9194$ & 89.07 & 88.69 & $7 / 7 / 97$ & 83.86 & 83.66 \\
\hline $7 / 17 / 89$ & 83.13 & 82.95 & $3 / 14 / 92$ & 85.11 & 84.86 & $11 / 10 / 94$ & 88.81 & 88.44 & $7 / 8 / 97$ & 84.75 & 84.52 \\
\hline $7 / 18 / 89$ & 84.81 & 84.57 & $3 / 15 / 92$ & 86.05 & 85.77 & $11 / 11 / 94$ & 88.77 & 88.40 & $7 / 9197$ & 85.25 & 85.00 \\
\hline $7 / 19 / 89$ & 85.69 & 85.42 & $3 / 16 / 92$ & 86.28 & 85.99 & $11 / 12 / 94$ & 89.52 & 89.12 & $7 / 10 / 97$ & 85.47 & 85.21 \\
\hline $7 / 20 / 89$ & & & $3 / 17 / 92$ & 88.23 & 87.88 & $11 / 13 / 94$ & 88.45 & 88.09 & $7 / 11 / 97$ & 85.55 & 85.29 \\
\hline $7 / 21 / 89$ & & & $3 / 18 / 92$ & 90.84 & 90.40 & $11 / 14 / 94$ & 87.61 & 87.28 & $7 / 12 / 97$ & 84.83 & 84.59 \\
\hline $7 / 22 / 89$ & & & $3 / 19 / 92$ & 91.59 & 91.12 & $11 / 15 / 94$ & 88.64 & 88.27 & $7 / 13 / 97$ & 83.82 & 83.62 \\
\hline $7 / 23 / 89$ & & & $3 / 20 / 92$ & 91.95 & 91.47 & $11 / 16 / 94$ & 88.49 & 88.13 & $7 / 14 / 97$ & 83.81 & 83.61 \\
\hline $7 / 24 / 89$ & & & $3 / 21 / 92$ & 92.09 & 91.60 & $11 / 17 / 94$ & 88.75 & 88.38 & $7 / 15 / 97$ & 85.81 & 85.54 \\
\hline $7 / 25 / 89$ & 84.94 & 84.70 & $3 / 22 / 92$ & 91.16 & 90.70 & $11 / 18 / 94$ & 88.61 & 88.24 & $7 / 16 / 97$ & 86.54 & 86.24 \\
\hline $7 / 26 / 89$ & 85.88 & 85.61 & $3 / 23 / 92$ & 89.58 & 89.18 & $11 / 19 / 94$ & 88.42 & 88.06 & $7 / 17 / 97$ & 86.81 & 86.50 \\
\hline $7 / 27 / 89$ & 85.03 & 84.79 & $3 / 24 / 92$ & 89.87 & 89.46 & $11 / 20 / 94$ & 87.64 & 87.31 & $7 / 18 / 97$ & 86.61 & 86.31 \\
\hline $7 / 28 / 89$ & 84.12 & 83.91 & $3 / 25 / 92$ & 91.66 & 91.19 & $11 / 21 / 94$ & 87.29 & 86.97 & $7 / 19 / 97$ & 86.33 & 86.04 \\
\hline $7 / 29 / 89$ & & & $3 / 26 / 92$ & 92.56 & 92.06 & $11 / 22 / 94$ & 89.06 & 88.68 & $7 \overline{20 / 97}$ & 84.54 & 84.31 \\
\hline $7 / 30 / 89$ & & & $3 / 27 / 92$ & 93.08 & 92.56 & $11 / 23 / 94$ & 89.97 & 89.56 & $7 / 21 / 97$ & 84.10 & 83.89 \\
\hline $7 / 31 / 89$ & & & $3 / 28 / 92$ & 92.91 & 92.39 & $11 / 24 / 94$ & 90.03 & 89.61 & $7 / 22197$ & 84.95 & 84.71 \\
\hline $8 / 1 / 89$ & & & $3 / 29 / 92$ & 91.65 & 91.18 & $11 / 25 / 94$ & 90.04 & 89.62 & $7 / 23 / 97$ & 86.15 & 85.87 \\
\hline $8 / 2 / 89$ & 85.08 & 84.83 & $3 / 30 / 92$ & 90.17 & 89.75 & $11 / 26 / 94$ & 89.73 & 89.32 & $7 \overline{24 / 97}$ & 85.94 & 85.66 \\
\hline $8 / 3 / 89$ & 84.09 & 83.88 & $3 / 31 / 92$ & 91.01 & 90.56 & $11 / 27 / 94$ & 87.54 & 87.21 & $7 \longdiv { 2 5 / 9 7 }$ & 86.82 & 86.51 \\
\hline $8 / 4 / 89$ & 83.82 & 83.62 & $4 / 1 / 92$ & 92.02 & 91.53 & $11 / 28 / 94$ & 85.07 & 84.82 & $7 \overline{26 / 97}$ & 86.67 & 86.37 \\
\hline $8 / 5 / 89$ & 82.74 & 82.57 & $4 / 2 / 92$ & 92.48 & 91.98 & $11 / 29 / 94$ & 86.98 & 86.67 & $7 \overline{27 / 97}$ & 85.49 & 85.23 \\
\hline$-8 / 6 / 89$ & $=81: 96$ & 81.82 & $=4 / 3 / 92$ & 92.72 & $=92.21$ & $=11 / 30 / 94$ & 88.92 & 88.54 & $7 \overline{28 / 97}$ & 84.69 & 84.46 \\
\hline $8 / 7 / 89$ & 81.74 & 81.61 & $4 / 4 / 92$ & 92.75 & 92.24 & $12 / 1 / 94$ & 90.00 & 89.58 & $7 / 29197$ & 84.87 & 84.63 \\
\hline $8 / 8 / 89$ & 81.66 & 81.53 & $4 / 5 / 92$ & 91.94 & 91.46 & $12 / 2 / 94$ & 90.63 & 90.19 & $7 / 30 / 97$ & 84.84 & 84.60 \\
\hline $8 / 9 / 89$ & 82.12 & 81.98 & $4 / 6 / 92$ & 89.93 & 89.52 & $12 / 3 / 94$ & 89.58 & 89.18 & $7 / 31 / 97$ & 84.57 & 84.34 \\
\hline $8 / 10 / 89$ & 82.36 & 82.21 & $4 / 7 / 92$ & 89.55 & 89.15 & $12 / 4 / 94$ & 88.56 & 88.19 & $8 / 1 / 97$ & 84.87 & 84.63 \\
\hline $8 / 11 / 89$ & 82.32 & 82.17 & $4 / 8 / 92$ & 90.21 & 89.79 & $12 / 5 / 94$ & 88.46 & 88.10 & $8 / 2 / 97$ & 85.88 & 85.61 \\
\hline $8 / 12 / 89$ & 81.69 & 81.56 & $4 / 9 / 92$ & 90.30 & 89.87 & $12 / 6194$ & 90.03 & 89.61 & $8 / 3 / 97$ & 85.49 & 85.23 \\
\hline $8 / 13 / 89$ & 81.50 & 81.38 & $4 / 10 / 92$ & 88.77 & 88.40 & $12 / 7 / 94$ & 90.52 & 90.09 & $8 / 4 / 97$ & 84.27 & 84.05 \\
\hline $8 / 14 / 89$ & 81.44 & 81.32 & $4 / 11 / 92$ & 86.33 & 86.04 & $12 / 8 / 94$ & 90.53 & 90.10 & $8 / 5 / 97$ & 86.35 & 86.06 \\
\hline
\end{tabular}


Appendix C (continued)

SR-TNX Estimated Historic Daily Mean Elevation

\begin{tabular}{|c|c|c|c|c|c|c|c|c|c|c|c|}
\hline Date & \begin{tabular}{c|} 
SR- \\
Jackson \\
Elevation \\
(ft-msl)
\end{tabular} & $\begin{array}{l}\text { SR-TNXX } \\
\text { Estimated } \\
\text { Elevation } \\
\text { (f-msl) } \\
\end{array}$ & Date & \begin{tabular}{|c|} 
SR- \\
Jackson \\
Elevation \\
(ft-msl) \\
\end{tabular} & $\begin{array}{l}\text { SR-TNX } \\
\text { Estimated } \\
\text { Elevation } \\
\text { (ft-msl) } \\
\end{array}$ & Date & \begin{tabular}{|c|} 
SR- \\
Jackson \\
Elevation \\
(ft-msl)
\end{tabular} & $\begin{array}{c}\text { SR-TNX } \\
\text { Estimated } \\
\text { Elevation } \\
\text { (ft-msl) }\end{array}$ & Date & \begin{tabular}{c|} 
SR- \\
Jackson \\
Elevation \\
(ft-msl)
\end{tabular} & \begin{tabular}{c|} 
SR-TNX \\
Estimated \\
Elevation \\
(ft-msl)
\end{tabular} \\
\hline $8 / 15 / 89$ & 81.56 & 81.44 & $4 / 12 / 92$ & 84.08 & 83.87 & $12 / 9 / 94$ & 90.90 & 90.45 & $8 / 6 / 97$ & 88.25 & 87.89 \\
\hline $8 / 16 / 89$ & 82.04 & 81.90 & $4 / 13 / 92$ & 83.92 & 83.71 & $12 / 10 / 94$ & 91.12 & 90.67 & $8 / 7 / 97$ & 88.82 & $\overline{88.45}$ \\
\hline $8 / 17 / 89$ & 82.63 & 82.47 & $4 / 14 / 92$ & \begin{tabular}{|l|}
84.38 \\
\end{tabular} & 84.16 & $12 / 11 / 94$ & 91.65 & 91.18 & $8 / 8 / 97$ & 88.50 & 88.14 \\
\hline $8 / 18 / 89$ & \begin{tabular}{|c|}
82.74 \\
\end{tabular} & 82.57 & $4 / 15 / 92$ & 84.99 & \begin{tabular}{|c|}
84.75 \\
\end{tabular} & $12 / 12 / 94$ & 92.04 & 91.55 & $8 / 9 / 97$ & 88.01 & 87.66 \\
\hline $8 / 19 / 89$ & 82.68 & 82.52 & $4 / 16 / 92$ & 84.66 & 84.43 & $12 / 13 / 94$ & 92.28 & 91.79 & $8 / 10 / 97$ & 86.22 & 85.93 \\
\hline $8 / 20 / 89$ & 81.73 & 81.60 & $4 / 17 / 92$ & 83.85 & 83.65 & $12 / 14 / 94$ & 92.34 & 91.84 & $8 / 11 / 97$ & 85.49 & 85.23 \\
\hline $8 / 21 / 89$ & 81.47 & 81.35 & $4 / 18 / 92$ & 83.45 & 83.26 & $12 / 15 / 94$ & 92.44 & 91.94 & $8 / 12 / 97$ & 86.73 & 86.43 \\
\hline $8 / 22 / 89$ & 81.43 & 81.31 & $4 / 19 / 92$ & 83.80 & 83.60 & $12 / 16 / 94$ & $\begin{array}{l}92.43 \\
\end{array}$ & 91.93 & $8 / 13 / 97$ & 87.19 & 86.87 \\
\hline $8 / 23 / 89$ & \begin{tabular}{l|l|}
82.65 \\
\end{tabular} & 82.49 & $4 / 20 / 92$ & 84.76 & 84.53 & $12 / 17 / 94$ & 92.36 & 91.86 & $8 / 14 / 97$ & $\overline{87.41}$ & 87.08 \\
\hline $8 / 24 / 89$ & 85.78 & 85.51 & $4 / 21 / 92$ & 84.95 & 84.71 & $12 / 18 / 94$ & \begin{tabular}{|l|l}
91.899 \\
\end{tabular} & 91.41 & $8 / 15 / 97$ & 87.42 & 87.09 \\
\hline $8 / 25 / 89$ & 85.55 & 85.29 & $.4 / 22 / 92$ & 86.53 & 86.23 & $12 / 19 / 94$ & 91.40 & 90.94 & $8 / 16 / 97$ & $\begin{array}{l}87.17 \\
\end{array}$ & 86.85 \\
\hline $8 / 26 / 89$ & \begin{tabular}{|l|}
84.23 \\
\end{tabular} & 84.01 & $4 / 23 / 92$ & 87.31 & 86.99 & $12 / 20 / 94$ & 91.26 & 90.80 & $8 / 17 / 97$ & 86.03 & 85.75 \\
\hline $8 / 27 / 89$ & 83.18 & 83.00 & $4 / 24 / 92$ & 87.13 & 86.81 & $12 / 21 / 94$ & 91.11 & 90.66 & $8 / 18 / 97$ & 85.42 & 85.16 \\
\hline $8 / 28 / 89$ & 81.99 & 81.85 & $4 / 25 / 92$ & 86.16 & 8 & $12 / 22 / 94$ & 90.86 & 90.41 & $8 / 19 / 97$ & $\begin{array}{l}87.28 \\
\end{array}$ & 86.96 \\
\hline $8 / 29 / 89$ & 83.60 & 83.41 & $4 / 26 / 92$ & 85.43 & 85.17 & $12 / 23 / 94$ & 91.31 & 90.85 & $8 / 20 / 97$ & $\begin{array}{l}87.37 \\
\end{array}$ & 87.05 \\
\hline $8 / 30 / 89$ & \begin{tabular}{|l|}
87.73 \\
\end{tabular} & 87.39 & $4 / 27 / 92$ & $84.63 \mid$ & 84.40 & $12 / 24 / 94$ & 93.01 & 92.49 & $8 / 21 / 97$ & \begin{tabular}{l|l|}
87.02 \\
\end{tabular} & $\overline{86.71}$ \\
\hline $8 / 31 / 89$ & 88.20 & 87.85 & $4 / 28 / 92$ & 84.94 & 84.70 & $12 / 25 / 94$ & 93.96 & $93.41 \mid$ & $8 / 22 / 97$ & 87.09 & 86.77 \\
\hline \begin{tabular}{|l|}
$9 / 1 / 89$ \\
\end{tabular} & 87.59 & 87.26 & $4 / 29 / 92$ & 84.85 & 84.61 & $12 / 26 / 94$ & 93.88 & 93.33 & $8 / 23 / 97$ & \begin{tabular}{|l|}
86.73 \\
\end{tabular} & 86.43 \\
\hline 9/2/89 & 86.69 & 86.39 & $4 / 30 / 92$ & 84.97 & 84.73 & $12 / 27 / 94$ & 91.96 & 91.48 & $8 / 24 / 97$ & 84.93 & 84.69 \\
\hline $9 / 3 / 89$ & 84.11 & 83.90 & $5 / 1 / 92$ & 84.23 & 84.01 & $12 / 28 / 94$ & 89.48 & 89.08 & $8 / 25 / 97$ & 85.49 & 85.23 \\
\hline $9 / 4 / 89$ & 82.14 & 82.00 & $5 / 2 / 92$ & 83.46 & 83.27 & $12 / 29 / 94$ & 87.87 & 87.53 & $8 / 26 / 97$ & 86.45 & 86.16 \\
\hline $9 / 5 / 89$ & 83.69 & 83.49 & $5 / 3 / 92$ & 83.79 & 83.59 & $12 / 30 / 94$ & 87.5 & 87.24 & $8 / 27 / 97$ & 86.72 & 86.42 \\
\hline $9 / 6 / 89$ & 86.97 & 86.66 & $5 / 4 / 92$ & 83.81 & 83.61 & $12 / 31 / 94$ & 86.00 & 85.72 & $8 / 28 / 97$ & 86.42 & 86.13 \\
\hline $9 / 7 / 89$ & 87.64 & 87.31 & $5 / 5 / 92$ & 84.23 & 84.01 & $1 / 1 / 95$ & 86.61 & 86.31 & $8 / 29 / 97$ & 85.17 & 84.92 \\
\hline \begin{tabular}{l|l|}
$9 / 8 / 89$ &
\end{tabular} & 87.98 & 87.63 & $5 / 6 / 92$ & 84.21 & 83.99 & $1 / 2 / 95$ & 86.91 & 86.60 & $8 / 30 / 97$ & 84.47 & 84.25 \\
\hline $9 / / 89$ & 88.21 & 87.86 & $5 / 7 / 92$ & \begin{tabular}{|l|}
83.97 \\
\end{tabular} & 83.76 & $1 / 3 / 95$ & 87.66 & 87.33 & $8 / 31 / 97$ & 83.57 & 83.38 \\
\hline $9 / 10 / 89$ & 84.81 & \begin{tabular}{|l|}
84.57 \\
\end{tabular} & $5 / 8 / 92$ & 84.00 & 83.79 & $1 / 4 / 95$ & 87.79 & 87.45 & 9/1/97| & 83.41 & 83.22 \\
\hline $9 / 11189$ & 82.28 & 82.13 & $5 / 9 / 92$ & 83.21 & 83.03 & $1 / 5 / 95$ & 88.11 & 87.76 & 92/97 & 83.23 & 83.0 \\
\hline $9 / 12 / 89$ & 84.15 & 83.94 & $5 / 10 / 92$ & 83.06 & 82.88 & $1 / 6 / 95$ & 86.71 & 86.41 & $9 / 3 / 97$ & 83.25 & 83.07 \\
\hline $9 / 13 / 89$ & 87.63 & 87.30 & $5 / 11 / 92$ & 83.49 & 83.30 & $1 / 7 / 95$ & 86.97 & 86.66 & 9/4/97 & 83.44 & 83.25 \\
\hline $9 / 14 / 89$ & 88.16 & 87.81 & $5 / 12 / 92$ & 83.48 & 83.29 & 1/8/95 & 89.00 & 88.62 & 9/5/97 & 83.12 & 82.94 \\
\hline $9 / 15 / 89$ & 85.86 & 85.59 & $5 / 13 / 92$ & 83.77 & 83.57 & $1 / 9 / 95$ & 89.35 & 88.96 & 9/6/97 & 82.96 & 82.79 \\
\hline $9 / 16 / 89$ & 84.80 & 84.56 & $5 / 14 / 92$ & 83.94 & 83.73 & $1 / 10 / 95$ & 88.77 & 88.40 & $9 / 7 / 97$ & 82.62 & 82.46 \\
\hline $9 / 17 / 89$ & 83.79 & 83.59 & $5 / 15 / 92$ & 84.05 & 83.84 & $1 / 11 / 95$ & 88.63 & 88.26 & 9/8/97 & 82.47 & 82.31 \\
\hline $9 / 18 / 89$ & 82.12 & 81.98 & $5 / 16 / 92$ & 83.61 & 83.41 & $1 / 12 / 95$ & 88.52 & 88.16 & 9/9/97 & 82.78 & 82.61 \\
\hline $9 / 19 / 89$ & 82.00 & 81.86 & $5 / 17 / 92$ & 82.92 & 82.75 & $1 / 13 / 95$ & 87.50 & 87.17 & $9 / 10 / 97$ & 83.25 & 83.07 \\
\hline $9 / 20 / 89$ & 84.16 & 83.95 & $5 / 18 / 92$ & 83.79 & 83.59 & $1 / 14 / 95$ & 87.40 & \begin{tabular}{|l|l|}
87.07 \\
\end{tabular} & $9 / 11 / 97$ & 82.68 & 82.52 \\
\hline $9 / 21 / 89$ & 85.04 & 84.80 & $5 / 19 / 92$ & 82.94 & 82.77 & $1 / 15 / 95$ & 90.16 & 89.74 & $9 / 12 / 97$ & 83.05 & 82.87 \\
\hline $9 / 22 / 89$ & 90.36 & 89.93 & $5 / 20 / 92$ & \begin{tabular}{|l|}
83.33 \\
\end{tabular} & 83.14 & $1 / 16 / 95$ & 92.84 & 92.33 & $9 / 13 / 97$ & 82.95 & 82.78 \\
\hline $9 / 23 / 89$ & 91.71 & 91.24 & $5 / 21 / 92$ & 84.21 & 83.99 & $1 / 17 / 95$ & 94.29 & 93.73 & $9 / 14 / 97$ & 82.64 & 82.48 \\
\hline $9 / 24 / 89$ & 89.75 & 89.34 & $5 / 22 / 92$ & 83.68 & 83.48 & $1 / 18 / 95$ & 94.78 & 94.20 & $9 / 15 / 97$ & 82.72 & 82.5 \\
\hline $9 / 25 / 89$ & 84.82 & 84.58 & $5 / 23 / 92$ & 82.8 & 82.69 & $1 / 19 / 95$ & 94.70 & 94.12 & $9 / 16 / 97$ & 83.47 & 83.28 \\
\hline $9 / 26 / 89$ & 83.07 & 82.89 & $5 / 24 / 92$ & 82.90 & 82.73 & $1 / 20 / 95$ & 94.69 & 94.11 & $9 / 17 / 9$ & 83.46 & 83.27 \\
\hline
\end{tabular}


Appendix $C$ (continued)

SR-TNX Estimated Historic Daily Mean Elevation

\begin{tabular}{|c|c|c|c|c|c|c|c|c|c|c|c|}
\hline Date & $\begin{array}{c}\text { SR- } \\
\text { Jackson } \\
\text { Elevation } \\
\text { (ft-msi) } \\
\end{array}$ & \begin{tabular}{c|} 
SR-TNX \\
Estimated \\
Elevation \\
$(\mathrm{ft}-\mathrm{ms}$ ) \\
\end{tabular} & Date & $\begin{array}{c}\text { SR- } \\
\text { Jackson } \\
\text { Elevation } \\
(\mathrm{ft}-\mathrm{msl}) \\
\end{array}$ & $\begin{array}{c}\text { SR-TNX } \\
\text { Estimated } \\
\text { Elevation } \\
\text { (ft-msl) } \\
\end{array}$ & Date & $\begin{array}{c}\text { SR- } \\
\text { Jackson } \\
\text { Elevation } \\
\text { (ft-msl) } \\
\end{array}$ & $\begin{array}{c}\text { SR-TNX } \\
\text { Estimated } \\
\text { Elevation } \\
(\mathrm{ft}-\mathrm{msl}) \\
\end{array}$ & Date & $\begin{array}{c}\text { SR- } \\
\text { Jackson } \\
\text { Elevation } \\
(\mathrm{f}-\mathrm{msl}) \\
\end{array}$ & \begin{tabular}{c|} 
SR-TNX \\
Estimated \\
Elevation \\
$(\mathrm{ft}-\mathrm{msl})$
\end{tabular} \\
\hline $9 / 27 / 89$ & 84.46 & 84.24 & $5 / 25 / 92$ & 82.72 & 82.56 & $1 / 21 / 95$ & 94.77 & 94.19 & 9/18/97 & 83.50 & 83.31 \\
\hline $9 / 28 / 89$ & 85.26 & 85.01 & $5 / 26 / 92$ & 82.92 & 82.75 & $1 / 22 / 95$ & 94.86 & 94.28 & $9 / 19 / 97$ & 83.24 & 83.06 \\
\hline $9 / 29 / 89$ & 84.34 & 84.12 & $5 \longdiv { 2 7 / 9 2 }$ & 83.26 & 83.08 & $1 / 23 / 95$ & 94.93 & 94.34 & $9 / 20 / 97$ & 82.99 & 82.82 \\
\hline $9 / 30 / 89$ & 84.02 & 83.81 & $5 / 28 / 92$ & 83.32 & 83.13 & $1 / 24 / 95$ & 94.65 & 94.07 & $9 / 21 / 97$ & 82.88 & 82.71 \\
\hline $10 / 1 / 89$ & & & $5 / 29 / 92$ & 83.16 & 82.98 & $1 / 25 / 95$ & 93.60 & 93.06 & $9 / 22 / 97$ & 82.16 & 82.01 \\
\hline $10 / 2 / 89$ & 85.04 & 84.80 & $5 / 30 / 92$ & 83.24 & 83.06 & $1 / 26 / 95$ & 92.73 & \begin{tabular}{l|}
92.22 \\
\end{tabular} & $9 / 23 / 97$ & 82.53 & 82.37 \\
\hline $10 / 3 / 89$ & 90.74 & 90.30 & $5 / 31 / 92$ & 83.09 & 82.91 & $1 / 27 / 95$ & 91.55 & 91.08 & $9 / 24 / 97$ & 82.76 & 82.59 \\
\hline $10 / 4 / 89$ & 92.80 & 92.29 & $6 / 1 / 92$ & 83.00 & 82.83 & $1 / 28 / 95$ & 90.81 & 90.37 & $9 / 25 / 97$ & 83.19 & 83.01 \\
\hline $10 / 5 / 89$ & 93.04 & 92.52 & $6 / 2 / 92$ & 82.96 & 82.79 & $1 / 29 / 95$ & 89.96 & 89.55 & $9 / 26 / 97$ & \begin{tabular}{l|l}
86.12 \\
\end{tabular} & 85.84 \\
\hline $10 / 6 / 89$ & 93.75 & 93.20 & $6 / 3 / 92$ & 84.92 & 84.68 & $1 / 30 / 95$ & 89.79 & 89.38 & $9 / 27 / 97$ & 86.69 & 86.39 \\
\hline $10 / 7 / 89$ & 94.43 & 93.86 & $6 / 4 / 92$ & 85.70 & 85.43 & $1 / 31 / 95$ & 89.59 & 89.19 & $9 / 28 / 97$ & 84.94 & 84.70 \\
\hline $10 / 8 / 89$ & 94.85 & 94.27 & $6 / 5 / 92$ & 83.76 & 83.56 & $2 / 1 / 95$ & 88.74 & 88.37 & $9 / 29 / 97$ & 83.73 & 83.53 \\
\hline $10 / 9 / 89$ & 94.73 & 94.15 & $6 / 6 / 92$ & 83.67 & 83.47 & $2 / 2 / 95$ & 87.62 & 87.29 & $9 / 30 / 97$ & 83.68 & 83.48 \\
\hline $10 / 10 / 89$ & 93.56 & 93.02 & $6 / 7 / 92$ & 83.55 & 83.36 & $2 / 3 / 95$ & 86.18 & 85.90 & $10 / 1 / 97$ & 83.50 & 83.31 \\
\hline $10 / 11 / 89$ & 92.78 & 92.27 & $6 / 8 / 92$ & 83.73 & 83.53 & $2 / 4 / 95$ & 87.24 & 86.92 & $10 / 2 / 97$ & 84.49 & 84.26 \\
\hline $10 / 12 / 89$ & 92.13 & 91.64 & $6 / 9 / 92$ & 85.98 & 85.70 & $2 / 5 / 95$ & 86.17 & 85.89 & $10 / 3 / 97$ & 84.28 & 84.06 \\
\hline $10 / 13 / 89$ & 91.79 & 91.31 & $6 / 10 / 92$ & 86.72 & 86.42 & $2 / 6 / 95$ & 86.24 & 85.95 & $10 / 4 / 97$ & 83.74 & 83.54 \\
\hline $10 / 14 / 89$ & 91.49 & 91.02 & $6 / 11 / 92$ & 86.33 & 86.04 & $2 / 7 / 95$ & 87.71 & 87.37 & $10 / 5 / 97$ & 83.26 & 83.08 \\
\hline $10 / 15 / 89$ & 88.03 & 87.68 & $6 / 12 / 92$ & 85.29 & 85.04 & $2 / 8 / 95$ & 86.99 & 86.68 & $10 / 6 / 97$ & 82.81 & 82.64 \\
\hline $10 / 16 / 89$ & 84.85 & 84.61 & $6 / 13 / 92$ & 85.96 & 85.68 & $2 / 9 / 95$ & 85.34 & 85.09 & 10/7/97 & 84.72 & 84.49 \\
\hline $10 / 17 / 89$ & 88.10 & 87.75 & $6 / 14 / 92$ & 85.64 & 85.37 & $2 \pi 0 / 95$ & 86.82 & 86.51 & $10 / 8 / 97$ & 85.42 & $85.16 \|$ \\
\hline $10 / 18 / 89$ & 90.90 & 90.45 & $6 / 15 / 92$ & 85.82 & 85.55 & $2 / 11 / 95$ & 88.32 & 87.96 & $10 / 9 / 97$ & 85.53 & 85.27 \\
\hline $10 / 19 / 89$ & 92.22 & 91.73 & $6 / 16192$ & 86.20 & 85.92 & $2 / 12 / 95$ & 92.15 & 91.66 & $10 / 10 / 97$ & 84.55 & 84.33 \\
\hline $10 / 20 / 89$ & 92.91 & 92.39 & $6 / 17 / 92$ & 87.63 & 87.30 & $2 / 13 / 95$ & 93.66 & 93.12 & $10 / 11 / 97$ & 84.23 & 84.01 \\
\hline $10 / 21 / 89$ & 92.95 & 92.43 & $6 / 18 / 92$ & 86.92 & 86.61 & $2 / 14 / 95$ & 93.96 & 93.41 & $10 / 12 / 97$ & 83.50 & 83.31 \\
\hline $10 / 22 / 89$ & 89.73 & 89.32 & $6 / 19 / 92$ & 86.10 & 85.82 & $2 / 15 / 95$ & 94.00 & 93.45 & $10 / 13 / 97$ & 82.81 & 82.64 \\
\hline $10 / 23 / 89$ & 84.78 & 84.54 & $6 / 20 / 92$ & 84.98 & 84.74 & $2 / 16 / 95$ & 94.00 & 93.45 & $10 / 14 / 97$ & 84.46 & 84.23 \\
\hline $10 / 24 / 89$ & 85.99 & 85.71 & $6 / 21 / 92$ & 84.23 & 84.01 & $2 / 17 / 95$ & 94.27 & 93.71 & $10 / 15 / 97$ & 83.70 & 83.50 \\
\hline $10 / 25 / 89$ & 89.26 & 88.87 & $6 / 22 / 92$ & 84.89 & 84.65 & $2 / 18 / 95$ & 94.55 & 93.98 & $10 / 16 / 97$ & 84.69 & 84.46 \\
\hline $10 / 26 / 89$ & 89.58 & 89.18 & $6 / 23 / 92$ & 86.70 & 86.40 & $2 / 19 / 95$ & 95.26 & 94.66 & $10 / 17 / 97$ & 83.76 & 83.56 \\
\hline $10 / 27 / 89$ & 89.75 & 89.34 & $6 / 24 / 92$ & 88.52 & 88.16 & $2 / 20 / 95$ & 95.84 & 95.22 & $10 / 18 / 97$ & 83.42 & 83.24 \\
\hline $10 / 28 / 89$ & 89.90 & 89.49 & $6 / 25 / 92$ & 89.01 & 88.63 & $2 / 21 / 95$ & 95.79 & 95.17 & $10 / 19 / 97$ & 83.79 & 83.59 \\
\hline $10 / 29 / 89$ & 85.84 & 85.57 & $6 / 26 / 92$ & 89.10 & 88.72 & $2 / 22195$ & 95.43 & 94.83 & $10 / 20 / 97$ & 83.39 & 83.20 \\
\hline $10 / 30 / 89$ & 82.77 & 82.60 & $6 / 27 / 92$ & 88.67 & 88.30 & $2 / 23 / 95$ & 95.34 & 94.74 & $10 / 21 / 97$ & 83.65 & 83.45 \\
\hline $10 / 31 / 89$ & 83.28 & 83.10 & $=6 / 28 / 92$ & 86.82 & 86.51 & $2 / 24 / 95$ & 95.56 & 94.95 & $10 / 22 / 97$ & 83.39 & 83.21 \\
\hline $11 / 1 / 89$ & 85.34 & 85.09 & $6 / 29 / 92$ & 85.05 & 84.81 & $2 / 25 / 95$ & 95.77 & 95.16 & $10 / 23 / 97$ & 83.77 & 83.57 \\
\hline $11 / 2 / 89$ & 86.10 & 85.82 & $6 / 30 / 92$ & 85.21 & 84.96 & $2 / 26 / 95$ & 95.86 & 95.24 & $10 / 24 / 97$ & 85.20 & 84.95 \\
\hline $11 / 3 / 89$ & 87.14 & 86.82 & $7 / 1 / 92$ & 86.03 & 85.75 & $2 / 27 / 95$ & 95.88 & 95.26 & $10 / 25 / 97$ & 85.26 & 85.01 \\
\hline $11 / 4 / 89$ & 87.32 & 87.00 & $7 / 2 / 92$ & 86.15 & 85.87 & $2 / 28 / 95$ & 95.87 & 95.25 & $10 / 26 / 97$ & 83.83 & 83.62 \\
\hline $11 / 5 / 89$ & 84.74 & 84.51 & $7 / 3 / 92$ & 86.61 & 86.31 & $3 / 1 / 95$ & 95.69 & 95.08 & $10 / 27 / 97$ & 85.14 & $\overline{84.89}$ \\
\hline $11 / 6 / 89$ & 82.46 & 82.30 & $7 / 4 / 92$ & 86.41 & 86.12 & $3 / 2 / 95$ & 95.51 & 94.90 & $10 / 28 / 97$ & 88.50 & 88.14 \\
\hline $11 / 7 / 89$ & 83.54 & 83.35 & $7 / 5 / 92$ & 85.00 & 84.76 & $3 / 3 / 95$ & 95.52 & 94.91 & $10 / 29 / 97$ & 88.83 & 88.45 \\
\hline $11 / 8 / 89$ & 85.25 & 85.00 & $7 / 6 / 92$ & 84.55 & 84.32 & $3 / 4 / 95$ & 95.17 & 94.58 & $10 / 30 / 97$ & 86.50 & 86.20 \\
\hline
\end{tabular}


Appendix C (continued)

SR-TNX Estimated Historic Daily Mean Elevation

\begin{tabular}{|c|c|c|c|c|c|c|c|c|c|c|c|}
\hline Date & $\begin{array}{c}\text { SR- } \\
\text { Jackson } \\
\text { Elevation } \\
\text { (ft-msl) }\end{array}$ & $\begin{array}{c}\text { SR-TNX } \\
\text { Estimated } \\
\text { Elevation } \\
\text { (ft-msl) }\end{array}$ & Date & $\begin{array}{c}\text { SR- } \\
\text { Jackson } \\
\text { Elcvation } \\
\text { (ft-msi) } \\
\end{array}$ & $\begin{array}{c}\text { SR-TNX } \\
\text { Estimated } \\
\text { Elevation } \\
\text { (ft-msl) }\end{array}$ & Date & $\begin{array}{c}\text { SR- } \\
\text { Jackson } \\
\text { Elevation } \\
(\mathrm{ft}-\mathrm{msl})\end{array}$ & $\begin{array}{l}\text { SR-TNX } \\
\text { Estimated } \\
\text { Elevation } \\
\text { (ft-msl) }\end{array}$ & Date & $\begin{array}{c}\text { SR- } \\
\text { Jackson } \\
\text { Elevation } \\
(\mathrm{f}-\mathrm{msl})\end{array}$ & \begin{tabular}{c|} 
SR-TNX \\
Estimated \\
Elevation \\
(ft-msl)
\end{tabular} \\
\hline $11 / 9 / 89$ & 85.32 & 85.07 & $7 / 7 / 92$ & 84.87 & 84.63 & $3 / 5 / 95$ & \begin{tabular}{|l|}
94.94 \\
\end{tabular} & 94.35 & $10 / 31 / 97$ & 85.52 & 85.26 \\
\hline $11 / 10 / 89$ & 84.56 & 84.33 & 7/8/92 & 85.32 & 85.07 & $3 / 6 / 95$ & 94.95 & 94.36 & $11 / 1 / 97$ & 84.17 & $\overline{83.95}$ \\
\hline $11 / 11 / 89$ & 85.13 & 84.88 & $7 / 9 / 92$ & 85.83 & 85.56 & $3 / 7 / 95$ & 94.91 & 94.32 & $11 / 2 / 97$ & 83.89 & 83.69 \\
\hline $11 / 12 / 89$ & 82.87 & 82.70 & $7 / 10 / 92$ & 85.89 & 85.62 & $3 / 8 / 95$ & 94.63 & 94.05 & $11 / 3 / 97$ & 84.05 & 83.84 \\
\hline $11 / 13 / 89$ & 82.28 & 82.13 & $7 / 11 / 92$ & 84.50 & 84.27 & $3 / 9195$ & 94.10 & 93.54 & $11 / 4 / 97$ & 84.62 & 84.39 \\
\hline $11 / 14 / 89$ & 82.57 & 82.41 & $7 / 12 / 92$ & 83.68 & 83.48 & $3 / 10 / 95$ & 94.28 & 93.72 & $11 / 5 / 97$ & 85.27 & 85.02 \\
\hline $11 / 15 / 89$ & 83.18 & 83.00 & $7 / 13 / 92$ & 84.27 & 84.05 & $3 / 11 / 95$ & 94.56 & 93.99 & $11 / 6 / 97$ & 84.93 & 84.69 \\
\hline $11 / 16 / 89$ & 83.66 & 83.46 & $7 / 14 / 92$ & 84.90 & 84.66 & $3 / 12 / 95$ & 94.70 & 94.12 & 11/7/97 & 82.96 & 82.78 \\
\hline $11 / 17 / 89$ & 84.49 & 84.26 & $7 / 15 / 92$ & 85.41 & 85.15 & $3 / 13 / 95$ & 94.73 & 94.15 & $11 / 8 / 97$ & 82.50 & 82.34 \\
\hline $11 / 18 / 89$ & 83.96 & 83.75 & $7 / 16 / 92$ & 84.88 & 84.64 & $3 / 14 / 95$ & 94.72 & 94.14 & 11/9/97| & 84.00 & 83.79 \\
\hline $11 / 19 / 89$ & 82.71 & 82.55 & $7 / 17 / 92$ & 84.50 & 84.27 & $3 / 15 / 95$ & 94.47 & 93.90 & $11 / 10 / 97$ & 83.23 & 83.05 \\
\hline $11 / 20 / 89$ & 82.67 & 82.51 & $7 / 18 / 92$ & 84.18 & 83.97 & $3 / 16 / 95$ & 94.42 & 93.85 & $11 / 11 / 97$ & 83.92 & 83.72 \\
\hline $11 / 21 / 89$ & 83.19 & 83.01 & $7 / 19 / 92$ & 83.58 & 83.39 & $3 / 17 / 95$ & 94.58 & 94.01 & $11 / 12 / 97$ & 83.86 & 83.65 \\
\hline $11 / 22 / 89$ & 82.37 & 82.22 & $7 / 20 / 92$ & 83.58 & 83.39 & $3 / 18 / 95$ & 94.72 & 94.14 & $11 / 13 / 97$ & 84.54 & 84.32 \\
\hline $11 / 23 / 89$ & 82.28 & 82.13 & $7 / 21 / 92$ & 84.13 & 83.92 & $3 / 19 / 95$ & 94.77 & 94.19 & $11 / 14 / 97$ & 86.09 & 85.81 \\
\hline $11 / 24 / 89$ & & & $7 / 22 / 92$ & 84.33 & 84.11 & $3 / 20 / 95$ & 94.78 & 94.20 & $11 / 15 / 97$ & 89.43 & 89.03 \\
\hline $11 / 25 / 89$ & 82.36 & 82.21 & $7 / 23 / 92$ & 84.55 & 84.32 & $3 / 21 / 95$ & 94.54 & 93.97 & $11 / 16 / 97$ & 90.27 & 89.84 \\
\hline $11 / 26 / 89$ & 82.14 & 82.00 & $7 / 24 / 92$ & 84.11 & 83.90 & $3 / 22 / 95$ & 93.53 & 92.99 & $11 / 17 / 97$ & 86.90 & 86.59 \\
\hline $11 / 27 / 89$ & 82.45 & 82.29 & $7 / 25 / 92$ & 83.93 & 83.72 & $3 / 23 / 95$ & 92.87 & 92.36 & $11 / 18 / 97$ & 85.47 & 85.21 \\
\hline $11 / 28 / 89$ & 84.51 & 84.28 & $7 / 26 / 92$ & 83.65 & 83.45 & $3 / 24 / 95$ & 92.78 & 92.27 & $11 / 19 / 97$ & 86.55 & 86.25 \\
\hline $11 / 29 / 89$ & 86.59 & 86.29 & $7 / 27 / 92$ & 83.73 & 83.53 & $3 / 25 / 95$ & 92.45 & 91.95 & $11 / 20 / 97$ & 85.79 & 85.52 \\
\hline $11 / 30 / 89$ & 88.33 & 87.97 & $7 / 28 / 92$ & 83.99 & 83.78 & $3 / 26 / 95$ & 90.75 & 90.31 & $11 / 21 / 97$ & 84.83 & 84.59 \\
\hline $12 / 1 / 89$ & 87.76 & 87.42 & $7 / 29 / 92$ & 84.56 & 84.33 & $3 / 27 / 95$ & 88.63 & 88.26 & $11 / 22 / 97$ & 84.32 & 84.10 \\
\hline $12 / 2 / 89$ & 86.90 & 86.59 & $7 / 30 / 92$ & 84.60 & 84.37 & $3 / 28 / 95$ & 88.37 & 88.01 & $11 / 23 / 97$ & 83.77 & 83.57 \\
\hline $12 / 3 / 89$ & 84.80 & 84.56 & $7 / 31192$ & 84.53 & 84.30 & $3 / 29 / 95$ & 87.48 & 87.15 & $11 / 24 / 97$ & 83.81 & 83.61 \\
\hline $12 / 4 / 89$ & 83.13 & 82.95 & $8 / 1 / 92$ & 84.61 & 84.38 & $3 / 30 / 95$ & 88.21 & 87.86 & $11 / 25 / 97$ & 83.42 & 83.23 \\
\hline $12 / 5 / 89$ & 86.32 & 86.03 & $8 / 2 / 92$ & 84.07 & 83.86 & $3 / 31 / 95$ & 88.44 & 88.08 & $11 / 26 / 97$ & 84.23 & 84.01 \\
\hline $12 / 6 / 89$ & 87.28 & 86.96 & $8 / 3 / 92$ & 83.54 & 83.35 & $4 / 1 / 95$ & 86.22 & 85.93 & $11 / 27 / 97$ & & \\
\hline $12 / 7 / 89$ & 88.17 & 87.82 & $8 / 4 / 92$ & 83.88 & 83.68 & $4 / 2 / 95$ & 86.18 & 85.90 & $11 / 28 / 97$ & 83.67 & 83.47 \\
\hline $12 / 8 / 89$ & 88.73 & 88.36 & $8 / 5 / 92$ & 84.73 & 84.50 & $4 / 3 / 95$ & 86.13 & 85.85 & $11 / 29197$ & 83.43 & 83.24 \\
\hline $12 / 9 / 89$ & 91.45 & 90.98 & $8 / 6 / 92$ & 86.02 & 85.74 & $4 / 4 / 95$ & 87.87 & 87.53 & $11 / 30 / 97$ & 83.45 & 83.26 \\
\hline $12 / 10 / 89$ & 93.20 & 92.67 & $8 / 7 / 92$ & 85.73 & 85.46 & $4 / 5 / 95$ & 88.43 & 88.07 & $12 / 1 / 97$ & 83.99 & 83.78 \\
\hline $12 / 11 / 89$ & 93.88 & 93.33 & $8 / 8 / 92$ & 84.25 & 84.03 & $4 / 6 / 95$ & 88.60 & 88.23 & $12 / 2 / 97$ & 86.13 & $\overline{85.85}$ \\
\hline $12 / 12 / 89$ & 93.95 & 93.40 & $8 / 9 / 92$ & 83.68 & 83.48 & $4 / 7 / 95$ & 88.99 & 88.61 & $12 / 3 / 97$ & 85.24 & 84.99 \\
\hline $12 / 13 / 89$ & 93.94 & 93.39 & $8 / 10 / 92$ & 83.78 & 83.58 & $4 / 8 / 95$ & 88.93 & 88.55 & $12 / 4 / 97$ & 85.11 & 84.86 \\
\hline $\mid 12 / 14 / 89$ & 94.07 & 93.51 & $8 / 11 / 92$ & 85.16 & 84.91 & $4 / 9 / 95$ & 87.80 & 87.46 & $12 / 5 / 97$ & 86.01 & 85.74 \\
\hline $12 / 15 / 89$ & 94.18 & 93.62 & $8 / 12 / 92$ & 85.72 & 85.45 & $4 / 10 / 95$ & 87.91 & 87.57 & $12 / 6 / 97$ & 85.98 & 85.70 \\
\hline $12 / 16 / 89$ & 94.00 & 93.45 & $8 / 13 / 92$ & 86.10 & 85.82 & $4 / 11 / 95$ & 87.69 & 87.35 & $12 / 7 / 97$ & 84.48 & 84.26 \\
\hline $12 / 17 / 89$ & 93.79 & 93.24 & $8 / 14 / 92$ & 87.56 & 87.23 & $4 / 12 / 95$ & 86.47 & 86.18 & $12 / 8 / 97$ & 83.60 & 83.40 \\
\hline $12 / 18 / 89$ & 93.57 & 93.03 & $8 / 15 / 92$ & 87.51 & 87.18 & $4 / 13 / 95$ & 84.38 & 84.16 & $12 / 9 / 97$ & 84.64 & 84.41 \\
\hline $12 / 19 / 89$ & 93.38 & 92.85 & $8 / 16 / 92$ & 86.01 & 85.73 & $4 / 14 / 95$ & 84.70 & 84.47 & $12 / 10 / 97$ & 84.21 & 83.99 \\
\hline $12 / 20 / 89$ & 93.56 & 93.02 & $8 / 17 / 92$ & 85.59 & 85.33 & $4 / 15 / 95$ & 85.13 & 84.88 & $12 / 11 / 97$ & 84.76 & 84.53 \\
\hline $12 / 21 / 89$ & 93.78 & 93.23 & $8 / 18 / 92$ & 86.16 & 85.88 & $4 / 16 / 95$ & 84.97 & 84.73 & $12 / 12 / 97$ & 85.55 & 85.29 \\
\hline
\end{tabular}


Appendix C (continued)

SR-TNX Estimated Historic Daily Mean Elevation

\begin{tabular}{|c|c|c|c|c|c|c|c|c|c|c|c|}
\hline Date & $\begin{array}{c}\text { SR- } \\
\text { Jackson } \\
\text { Elevation } \\
\text { (ft-msl) }\end{array}$ & $\begin{array}{c}\text { SR-TNX } \\
\text { Estimated } \\
\text { Elevation } \\
(\mathrm{ft}-\mathrm{msl})\end{array}$ & Date & $\begin{array}{c}\text { SR- } \\
\text { Jackson } \\
\text { Elevation } \\
\text { (ft-msl) }\end{array}$ & $\begin{array}{c}\text { SR-TNX } \\
\text { Estimated } \\
\text { Elevation } \\
\text { (ft-msl) }\end{array}$ & Date & $\begin{array}{c}\text { SR- } \\
\text { Jackson } \\
\text { Elevation } \\
\text { (ft-msl) }\end{array}$ & $\begin{array}{l}\text { SR-TNX } \\
\text { Estimated } \\
\text { Elevation } \\
\text { (ft-msl) }\end{array}$ & Date & $\begin{array}{c}\text { SR- } \\
\text { Jackson } \\
\text { Elevation } \\
\text { (ft-msl) }\end{array}$ & $\begin{array}{c}\text { SR-TNX } \\
\text { Estimated } \\
\text { Elevation } \\
(\mathrm{ft}-\mathrm{ms})\end{array}$ \\
\hline $12 / 22 / 89$ & 93.70 & 93.16 & $8 / 19192$ & 86.30 & 86.01 & $4 / 17 / 95$ & 84.64 & 84.41 & $12 / 13 / 97$ & 85.17 & 84.92 \\
\hline $12 / 23 / 89$ & 93.70 & 93.16 & $8 / 20 / 92$ & 87.66 & 87.33 & $4 / 18 / 95$ & 84.01 & 83.80 & $12 / 4 / 97$ & 85.62 & 85.35 \\
\hline $12 / 24 / 89$ & 93.86 & 93.31 & $8 / 21 / 92$ & 88.64 & 88.27 & $4 / 19 / 95$ & 84.25 & 84.03 & $12 / 15 / 97$ & 85.90 & 85.62 \\
\hline $12 / 25 / 89$ & 93.85 & 93.30 & $8 / 22 / 92$ & 88.53 & 88.17 & $4 / 20 / 95$ & 84.65 & 84.42 & $12 / 16 / 97$ & 86.73 & 86.42 \\
\hline $12 / 26 / 89$ & 93.58 & 93.04 & $8 / 23 / 92$ & 87.04 & 86.73 & $4 / 21 / 95$ & 85.48 & 85.22 & $12 / 17 / 97$ & 89.98 & 89.56 \\
\hline $12 / 27 / 89$ & 93.46 & 92.92 & $8 / 24 / 92$ & 86.26 & 85.97 & $4 / 22 / 95$ & 85.34 & 85.09 & $12 / 18 / 97$ & 90.24 & 89.82 \\
\hline $12 / 28 / 89$ & 93.39 & 92.86 & $8 / 25 / 92$ & 86.82 & 86.51 & $4 / 23 / 95$ & 85.09 & 84.84 & $12 / 19 / 97$ & 90.54 & 90.11 \\
\hline $12 / 29 / 89$ & 93.29 & 92.76 & $8 / 26 / 92$ & 86.75 & 86.45 & $4 / 24 / 95$ & 85.08 & 84.83 & $12 / 20 / 97$ & 90.90 & 90.45 \\
\hline $12 / 30 / 89$ & 93.14 & 92.62 & $8 / 27 / 92$ & 86.52 & 86.22 & $4 / 25 / 95$ & 84.68 & 84.45 & $12 / 21 / 97$ & 90.27 & 89.84 \\
\hline $12 / 31 / 89$ & 90.54 & 90.11 & $8 / 28 / 92$ & 86.43 & 86.14 & $4 / 26 / 95$ & 84.40 & 84.18 & $12 / 22 / 97$ & 89.46 & 89.07 \\
\hline $1 / 1 / 90$ & 85.96 & 85.68 & $8 / 29 / 92$ & 85.97 & 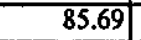 & $4 / 27 / 95$ & 84.12 & 83.91 & $12 / 23 / 97$ & 90.24 & 89.82 \\
\hline $1 / 2 / 90$ & 86.10 & 85.82 & $8 / 30 / 92$ & 84.42 & 84.20 & $4 / 28 / 95$ & 83.96 & 83.75 & $12 / 24 / 97$ & 91.01 & 90.56 \\
\hline $1 / 3 / 90$ & 88.73 & 88.36 & $8 / 31 / 92$ & 83.70 & 83.50 & $4 / 29 / 95$ & 84.06 & 83.85 & $12 / 25 / 97$ & 92.65 & 92.15 \\
\hline $1 / 4 / 90$ & 88.71 & 88.34 & $9 / 1 / 92$ & 84.87 & 84.63 & $4 / 30 / 95$ & 84.08 & 83.87 & $12 / 26 / 97$ & 93.91 & 93.36 \\
\hline $1 / 5 / 90$ & 88.59 & 88.22 & $9 / 2 / 92$ & 85.85 & 85.58 & $5 / 1 / 95$ & 83.95 & 83.74 & $12 / 27 / 97$ & 94.48 & 93.91 \\
\hline $1 / 6 / 90$ & 88.71 & 88.34 & $9 / 3 / 92$ & 85.88 & 85.61 & $5 / 2 / 95$ & 83.86 & 83.66 & $12 / 28 / 97$ & 93.78 & 93.23 \\
\hline $1 / 7 / 90$ & 86.61 & 86.31 & 9/4/92 & 85.95 & 85.67 & $5 / 3 / 95$ & 84.02 & 83.81 & $12 / 29 / 97$ & 92.36 & 91.86 \\
\hline $1 / 8 / 90$ & 85.33 & 85.08 & $9 / 5 / 92$ & 85.29 & 85.04 & $5 / 4 / 95$ & 84.31 & 84.09 & $12 / 30 / 97$ & 91.79 & 91.31 \\
\hline $1 / 9 / 90$ & 88.00 & 87.65 & $9 / 6 / 92$ & 85.28 & 85.03 & $5 / 5 / 95$ & 84.45 & 84.23 & $12 / 31 / 97$ & 92.84 & 92.32 \\
\hline $1 / 10 / 90$ & 89.76 & 89.35 & $9 / 7 / 92$ & 85.05 & 84.81 & $5 / 6 / 95$ & 84.69 & 84.46 & $1 / 1 / 98$ & 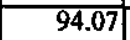 & 93.52 \\
\hline $1 / 11 / 90$ & 88.10 & 87.75 & $9 / 8 / 92$ & 85.24 & 84.99 & $5 / 7 / 95$ & 85.31 & 85.06 & $1 / 2 / 98$ & 94.77 & 94.19 \\
\hline $1 / 12190$ & 86.62 & 86.32 & $9 / 9192$ & 84.99 & 84.75 & $5 / 8 / 95$ & 84.65 & 84.42 & $1 / 3 / 98$ & 95.03 & 94.44 \\
\hline $1 / 13 / 90$ & 85.49 & 85.23 & $9 / 10 / 92$ & 84.73 & 84.50 & $\overline{S / 9 / 95}$ & 84.35 & 84.13 & $1 / 4 / 98$ & 94.82 & 94.24 \\
\hline $1 / 14 / 90$ & 84.52 & 84.29 & $9 / 11 / 92$ & 84.73 & 84.50 & $5 / 10 / 95$ & 84.25 & 84.03 & $1 / 5 / 98$ & 94.29 & 93.72 \\
\hline $1 / 15 / 90$ & 82.99 & 82.82 & $9 / 12 / 92$ & 84.84 & 84.60 & $5 / 11 / 95$ & 84.38 & 84.16 & $1 / 6 / 98$ & 94.13 & 93.57 \\
\hline $1 / 16 / 90$ & 85.82 & 85.55 & $9 / 13 / 92$ & 84.66 & 84.43 & $5 / 12 / 95$ & 84.76 & 84.53 & $1 / 7 / 98$ & 93.94 & 93.38 \\
\hline $1 / 17 / 90$ & 90.06 & 89.64 & $9 / 14 / 92$ & 84.43 & 84.21 & $5 / 13 / 95$ & 84.55 & 84.32 & $1 / 8 / 98$ & 93.37 & 92.83 \\
\hline $1 / 18 / 90$ & 90.57 & 90.13 & $9 / 15 / 92$ & 85.69 & 85.42 & $5 / 14 / 95$ & 84.10 & 83.89 & $1 / 9198$ & 91.96 & 91.48 \\
\hline $1 / 19 / 90$ & 90.39 & 89.96 & $9 / 16 / 92$ & 85.88 & 85.61 & $5 / 15 / 95$ & 83.79 & 83.59 & $1 / 10 / 98$ & 91.82 & 91.34 \\
\hline $1 / 20 / 90$ & 90.11 & 89.69 & $9 / 17 / 92$ & 84.02 & 83.81 & $5 / 16 / 95$ & 83.72 & 83.52 & 1/11/98 & 93.21 & 92.69 \\
\hline $1 / 21 / 90$ & 86.73 & 86.43 & $9 / 18 / 92$ & 84.37 & 84.15 & $5 / 17 / 95$ & 84.42 & 84.20 & $1 / 12 / 98$ & 94.14 & 93.58 \\
\hline $1 / 22 / 90$ & 83.64 & 83.44 & $9 / 19 / 92$ & 85.46 & 85.20 & $5 / 18 / 95$ & 84.70 & 84.47 & $1 / 13 / 98$ & 94.69 & 94.11 \\
\hline $1 / 23 / 90$ & 87.43 & 87.10 & $9 / 20192$ & 84.15 & 83.94 & $5 / 19 / 95$ & 84.64 & 84.41 & $1 / 14 / 98$ & 94.82 & 94.24 \\
\hline $1 / 24 / 90$ & 89.43 & 89.03 & $9 / 21 / 92$ & 83.41 & 83.22 & $5 / 20 / 95$ & 84.93 & 84.69 & $1 / 15 / 98$ & 94.69 & 94.11 \\
\hline $1 / 25 / 90$ & 89.97 & 89.56 & $9 / 22 / 92$ & 85.25 & 85.00 & $5 / 21 / 95$ & 84.47 & 84.25 & $=1 / 16 / 98$ & 94.77 & 94.19 \\
\hline $1 / 26 / 90$ & 89.72 & 89.31 & $9 / 23 / 92$ & 86.03 & 85.75 & $5 / 22 / 95$ & 84.04 & 83.83 & $1 / 17 / 98$ & 94.90 & 94.31 \\
\hline $1 / 27 / 90$ & 89.91 & 89.50 & $9 / 24 / 92$ & 86.06 & 85.78 & $5 / 23 / 95$ & 83.77 & 83.57 & $1 / 18 / 98$ & 95.06 & 94.47 \\
\hline $1 / 28 / 90$ & 88.77 & 88.40 & $9 / 25 / 92$ & 85.04 & 84.80 & $5 / 24 / 95$ & 84.10 & 83.89 & $1 / 19 / 98$ & 94.98 & 94.39 \\
\hline $1 / 29 / 90$ & 86.09 & 85.81 & $9 \longdiv { 2 6 1 9 2 }$ & 84.13 & 83.92 & $5 / 25 / 95$ & 83.86 & 83.66 & $1 / 20 / 98$ & 94.74 & $\overline{94.16}$ \\
\hline $1 / 30 / 90$ & 90.16 & 89.74 & $9 / 27 / 92$ & 84.05 & 83.84 & $5 / 26 / 95$ & 83.73 & 83.53 & $1 / 21 / 98$ & 94.56 & 93.98 \\
\hline $1 / 31 / 90$ & 91.80 & 91.32 & $9 / 28 / 92$ & 83.84 & 83.64 & $5 / 27 / 95$ & 83.57 & 83.38 & $1 / 22198$ & 94.55 & 93.98 \\
\hline $2 / 1 / 90$ & 92.33 & 91.83 & $9 / 29 / 92$ & 84.87 & 84.63 & $5 / 28 / 95$ & 83.36 & 83.17 & $1 / 23 / 98$ & 94.62 & 94.05 \\
\hline $2 / 2 / 90$ & 92.43 & 91.93 & 9/30/92 & 85.79 & 85.52 & $5 \longdiv { 2 9 / 9 5 }$ & 83.34 & 83.15 & $1 / 24 / 98$ & 94.72 & 94.14 \\
\hline
\end{tabular}


Appendix $\mathrm{C}$ (continued)

SR-TNX Estimated Historic Daily Mean Elevation

\begin{tabular}{|c|c|c|c|c|c|c|c|c|c|c|c|}
\hline Date & $\begin{array}{c}\text { SR- } \\
\text { Jackson } \\
\text { Elevation } \\
\text { (ft-msl) }\end{array}$ & $\begin{array}{c}\text { SR-TNX } \\
\text { Estimated } \\
\text { Elevation } \\
\text { (ft-msl) }\end{array}$ & Date & $\begin{array}{c}\text { SR- } \\
\text { Jackson } \\
\text { Elevation } \\
(\mathrm{ft}-\mathrm{msl})\end{array}$ & $\begin{array}{c}\text { SR-TNX } \\
\text { Estimated } \\
\text { Elevation } \\
\text { (ft-msl) }\end{array}$ & Date & $\begin{array}{c}\text { SR- } \\
\text { Jackson } \\
\text { Elevation } \\
\text { (ft-msl) }\end{array}$ & $\begin{array}{c}\text { SR-TNX } \\
\text { Estimated } \\
\text { Elevation } \\
\text { (ft-msl) }\end{array}$ & Date & \begin{tabular}{|c|} 
SR- \\
Jackson \\
Elevation \\
(ft-msl)
\end{tabular} & \begin{tabular}{c|} 
SR-TNX \\
Estimated \\
Elevation \\
(ft-msl)
\end{tabular} \\
\hline $2 / 3 / 90$ & 92.30 & 91.80 & $10 / 1 / 92$ & 86.30 & 86.01 & $5 / 30 / 95$ & 83.66 & 83.46 & $1 / 25 / 98$ & 94.58 & 94.00 \\
\hline $2 / 4 / 90$ & 89.15 & 88.76 & $10 / 2 / 92$ & 86.15 & 85.87 & $5 / 31 / 95$ & 83.73 & 83.53 & $1 / 26 / 98$ & 94.36 & 93.79 \\
\hline $2 / 5 / 90$ & 84.92 & 84.68 & $10 / 3 / 92$ & 84.99 & 84.75 & $6 / 1 / 95$ & 83.63 & 83.43 & $1 / 27 / 98$ & 94.50 & 93.92 \\
\hline $2 / 6 / 90$ & 89.13 & 88.74 & $10 / 4 / 92$ & 85.20 & 84.95 & $6 / 2195$ & 83.82 & 83.62 & $1 / 28 / 98$ & 94.83 & 94.25 \\
\hline $2 / 7 / 90$ & 91.38 & 90.92 & $10 / 5 / 92$ & 85.78 & 85.51 & $6 / 3 / 95$ & 84.25 & 84.03 & $1 / 29 / 98$ & 95.28 & 94.68 \\
\hline $2 / 8 / 90$ & 92.02 & 91.53 & $10 / 6 / 92$ & 86.92 & 86.61 & $6 / 4 / 95$ & 84.42 & 84.20 & $1 / 30 / 98$ & 95.55 & 94.94 \\
\hline $2 / 9 / 90$ & 92.25 & 91.76 & $10 / 7 / 92$ & 89.24 & 88.85 & $6 / 5 / 95$ & 84.97 & 84.73 & $1 / 31 / 98$ & 95.43 & 94.82 \\
\hline $2 / 10 / 90$ & 92.25 & 91.76 & 10/8/92 & 90.17 & 89.75 & $6 / 6 / 95$ & 87.82 & 87.48 & $2 / 1 / 98$ & & \\
\hline $2 / 11 / 90$ & 91.50 & 91.03 & $10 / 9 / 92$ & 90.93 & 90.48 & $6 / 7 / 95$ & 87.74 & 87.40 & $2 / 2 / 98$ & 95.23 & 94.63 \\
\hline $2 / 12 / 90$ & 91.43 & 90.96 & $10 / 10 / 92$ & 92.16 & 91.67 & 6/8/95 & 86.94 & 86.63 & $2 / 3 / 98$ & 95.28 & 94.68 \\
\hline $2 / 13 / 90$ & 91.54 & 91.07 & $10 / 11 / 92$ & 92.08 & 91.59 & $6 / 9 / 95$ & 86.53 & 86.23 & 2/4/98 & 95.40 & 94.80 \\
\hline $2 / 14 / 90$ & 93.02 & 92.50 & $10 / 12 / 92$ & 90.00 & 89.58 & $6 / 10 / 95$ & 85.99 & 85.71 & $2 / 5 / 98$ & 95.71 & 95.10 \\
\hline $2 / 15 / 90$ & 93.94 & 93.39 & $10 / 13 / 92$ & 89.83 & 89.42 & $6 / 11 / 95$ & 85.52 & 85.26 & $2 / 6 / 98$ & 96.22 & 95.59 \\
\hline $2 / 16 / 90$ & 94.57 & 94.00 & $10 / 14 / 92$ & 89.35 & 88.96 & $6 / 12 / 95$ & 85.14 & 84.89 & $2 / 7 / 98$ & 96.37 & 95.74 \\
\hline $2 / 17 / 90$ & 95.06 & 94.47 & $10 / 15 / 92$ & 89.34 & 88.95 & $6 / 13 / 95$ & 84.51 & 84.28 & $2 / 8 / 98$ & 96.71 & 96.06 \\
\hline $2 / 18 / 90$ & 95.19 & 94.60 & $10 / 16 / 92$ & 88.40 & 88.04 & $6 / 14 / 95$ & 83.97 & 83.76 & $2 / 9 / 98$ & 96.76 & 96.11 \\
\hline $2 / 19 / 90$ & 95.04 & 94.45 & $10 / 17 / 92$ & 88.48 & 88.12 & $6 / 15 / 95$ & 83.55 & 83.36 & $2 / 10 / 98$ & 96.50 & 95.86 \\
\hline $2 / 20 / 90$ & 95.31 & 94.71 & $10 / 18 / 92$ & 88.88 & 88.50 & $6 / 16 / 95$ & 83.57 & 83.38 & $2 / 11 / 98$ & 96.41 & 95.77 \\
\hline $2 / 21 / 90$ & 95.85 & 95.23 & $10 / 19 / 92$ & 88.12 & 87.77 & $6 / 17 / 95$ & 83.53 & 83.34 & $2 / 12 / 98$ & 96.41 & 95.77 \\
\hline $2 / 22 / 90$ & 96.23 & 95.60 & $10 / 20 / 92$ & 90.75 & 90.31 & $6 / 18 / 95$ & 83.74 & 83.54 & $2 / 13 / 98$ & 96.34 & 95.71 \\
\hline $2 / 23 / 90$ & 96.15 & 95.52 & $.10 / 21 / 92$ & 92.18 & 91.69 & $6 / 19 / 95$ & 83.68 & 83.48 & $2 / 14 / 98$ & 96.29 & 95.66 \\
\hline $2 / 24 / 90$ & 95.89 & 95.27 & $10 / 22 / 92$ & 92.53 & 92.03 & $6 / 20 / 95$ & 83.54 & 83.35 & $2 / 15 / 98$ & 96.22 & 95.59 \\
\hline $2 / 25 / 90$ & 95.82 & 95.20 & $10 / 23 / 92$ & \begin{tabular}{|l|}
92.73 \\
\end{tabular} & 92.22 & $6 / 21 / 95$ & 83.49 & 83.30 & $2 / 16 / 98$ & 96.20 & 95.57 \\
\hline $2 / 26 / 90$ & 96.11 & 95.48 & $10 / 24 / 92$ & 92.80 & 92.29 & $6 / 22 / 95$ & 83.63 & 83.43 & $2 / 17 / 98$ & 95.81 & 95.19 \\
\hline $2 / 27 / 90$ & 96.34 & 95.71 & $10 / 25 / 92$ & 91.78 & 91.30 & $6 / 23 / 95$ & 84.11 & 83.90 & $2 / 18 / 98$ & 95.09 & 94.50 \\
\hline $2 / 28 / 90$ & 96.54 & 95.90 & $10 / 26 / 92$ & 89.22 & 88.83 & $6 / 24 / 95$ & 84.36 & 84.14 & $2 / 19 / 98$ & 95.22 & 94.62 \\
\hline $3 / 1 / 90$ & 96.53 & 95.89 & $10 / 27 / 92$ & 87.13 & 86.81 & $6 / 25 / 95$ & 84.30 & 84.08 & $2 / 20 / 98$ & 95.50 & 94.89 \\
\hline $3 / 2 / 90$ & 96.10 & 95.47 & $10 / 28 / 92$ & 85.57 & 85.31 & $6 / 26 / 95$ & 83.68 & 83.48 & $2 / 21 / 98$ & 95.50 & 94.90 \\
\hline $3 / 3 / 90$ & \begin{tabular}{l|l|}
95.52 \\
\end{tabular} & 94.91 & $10 / 29 / 92$ & 85.68 & 85.41 & $6 / 27 / 95$ & 83.45 & 83.26 & $2 / 22198$ & 95.48 & 94.87 \\
\hline $3 / 4 / 90$ & 95.21 & 94.61 & $10 / 30 / 92$ & 85.72 & 85.45 & $6 / 28 / 95$ & 84.05 & 83.84 & $2 / 23 / 98$ & 95.51 & 94.90 \\
\hline $3 / 5 / 90$ & 95.19 & 94.60 & $10 / 31 / 92$ & 84.98 & \begin{tabular}{l|}
84.74 \\
\end{tabular} & $6 / 29 / 95$ & 84.31 & 84.09 & $2 / 24 / 98$ & 95.55 & 94.95 \\
\hline $3 / 6 / 90$ & 95.13 & 94.54 & $11 / 1 / 92$ & 84.06 & 83.85 & $6 / 30 / 95$ & 84.03 & 83.82 & $2 / 25 / 98$ & 95.62 & 95.01 \\
\hline $3 / 7 / 90$ & 95.17 & 94.58 & $11 / 2 / 92$ & 83.96 & 83.75 & $7 / 195$ & 83.95 & 83.74 & $2 / 26 / 98$ & 95.56 & 94.95 \\
\hline $3 / 8 / 90$ & 95.25 & 94.65 & $11 / 3 / 92$ & 84.28 & 84.06 & $7 / 2 / 95$ & 83.91 & 83.70 & $2 / 27 / 98$ & 95.60 & 94.99 \\
\hline $3 / 9 / 90$ & 95.28 & 94.68 & $11 / 4 / 92$ & 84.15 & 83.94 & $7 / 3 / 95$ & 84.00 & 83.79 & $2 / 28 / 98$ & 95.64 & 95.03 \\
\hline $3 / 10 / 90$ & 95.28 & 94.68 & $11 / 5 / 92$ & 84.88 & 84.64 & $7 / 4 / 95$ & 83.78 & 83.58 & $3 / 1 / 98$ & 95.70 & 95.09 \\
\hline $3 / 11 / 90$ & 95.24 & 94.64 & $11 / 6 / 92$ & 85.40 & 85.14 & $7 / 5 / 95$ & 83.53 & 83.34 & $3 / 2 / 98$ & 95.70 & 95.08 \\
\hline $3 / 12 / 90$ & 95.23 & 94.63 & $11 / 7 / 92$ & 86.52 & 86.22 & $7 / 6 / 95$ & 84.09 & 83.88 & $3 / 3 / 98$ & 95.66 & 95.05 \\
\hline $3 / 13 / 90$ & 95.30 & 94.70 & $11 / 8 / 92$ & 85.00 & 84.76 & $7 / 7 / 95$ & 84.45 & 84.23 & $3 / 4 / 98$ & 95.59 & 94.99 \\
\hline $3 / 14 / 90$ & 95.35 & 94.75 & $11 / 9 / 92$ & 84.69 & 84.46 & $7 / 8 / 95$ & 84.35 & 84.13 & $3 / 5 / 98$ & 95.57 & 94.96 \\
\hline $3 / 15 / 90$ & \begin{tabular}{l|l}
95.33 \\
\end{tabular} & 94.73 & $11 / 10 / 92$ & 85.99 & 85.71 & $7 / 9 / 95$ & 83.93 & 83.72 & $3 / 6 / 98$ & 95.60 & 94.99 \\
\hline $3 / 16 / 90$ & 95.28 & 94.68 & $11 / 11 / 92$ & 86.05 & 85.77 & $7 / 10 / 95$ & 83.54 & 83.35 & $3 / 7 / 98$ & 95.66 & 95.05 \\
\hline $3 / 17 / 90$ & 95.21 & 94.61 & I1/12/92 & 85.75 & 85.48 & $7 / 11 / 95$ & 83.43 & 83.24 & $3 / 8 / 98$ & 95.46 & 94.86 \\
\hline
\end{tabular}


Appendix C (continued)

SR-TNX Estimated Historic Daily Mean Elevation

\begin{tabular}{|c|c|c|c|c|c|c|c|c|c|c|c|}
\hline Date & $\begin{array}{c}\text { SR- } \\
\text { Jackson } \\
\text { Elevation } \\
\text { (ft-msl) }\end{array}$ & $\begin{array}{l}\text { SR-TNX } \\
\text { Estimated } \\
\text { Elevation } \\
\text { (ft-msl) }\end{array}$ & Date & $\begin{array}{c}\text { SR- } \\
\text { Jackson } \\
\text { Elevation } \\
\text { (ft-msi) } \\
\end{array}$ & $\begin{array}{l}\text { SR-TNX } \\
\text { Estimated } \\
\text { Elevation } \\
\text { (ft-msl) }\end{array}$ & Date & $\begin{array}{c}\text { SR- } \\
\text { Jackson } \\
\text { Elevation } \\
\text { (ft-msl) }\end{array}$ & $\begin{array}{c}\text { SR-TNX } \\
\text { Estimated } \\
\text { Elevation } \\
\text { (ft-msl) }\end{array}$ & Date & $\begin{array}{c}\text { SR- } \\
\text { Jackson } \\
\text { Elevation } \\
\text { (ft-msl) }\end{array}$ & \begin{tabular}{c|} 
SR-TNX \\
Estimated \\
Elevation \\
(ft-msl)
\end{tabular} \\
\hline $3 / 18 / 90$ & 94.91 & 94.32 & $11 / 13 / 92$ & 86.47 & 86.18 & $7 / 12 / 95$ & 83.66 & 83.46 & $3 / 9 / 98$ & 95.49 & 94.89 \\
\hline $3 / 19 / 90$ & 95.21 & 94.61 & $11 / 14 / 92$ & 87.56 & 87.23 & $7 / 13 / 95$ & 83.83 & 83.63 & $3 / 10 / 98$ & 95.91 & $\overline{95.29}$ \\
\hline $3 / 20 / 90$ & 95.85 & 95.23 & $11 / 15 / 92$ & 90.50 & 90.07 & $7 / 14 / 95$ & 83.92 & 83.71 & $3 / 11 / 98$ & 95.86 & 95.24 \\
\hline $3 / 21 / 90$ & 96.08 & 95.45 & $11 / 16 / 92$ & 90.09 & 89.67 & $7 / 15 / 95$ & 84.05 & 83.84 & $3 / 12 / 98$ & 95.30 & 94.70 \\
\hline $3 / 22 / 90$ & 96.13 & 95.50 & $11 / 17 / 92$ & 87.39 & 87.06 & $7 / 16 / 95$ & 84.09 & 83.88 & $3 / 13 / 98$ & 95.23 & 94.64 \\
\hline $3 / 23 / 90$ & 96.18 & 95.55 & $11 / 18 / 92$ & 91.39 & 90.93 & $7 / 17 / 95$ & 84.16 & 83.95 & $3 / 14 / 98$ & 95.45 & 94.85 \\
\hline $3 / 24 / 90$ & 96.22 & 95.59 & $11 / 19 / 92$ & 92.53 & 92.03 & $7 / 18 / 95$ & 84.98 & 84.74 & $3 / 15 / 98$ & $95 . \overline{57}$ & 94.96 \\
\hline $3 / 25 / 90$ & 96.23 & 95.60 & $11 / 20 / 92$ & 93.14 & 92.62 & $7 / 19 / 95$ & 85.97 & 85.69 & $3 / 16 / 98$ & 95.58 & 94.97 \\
\hline $3 / 26 / 90$ & 96.24 & 95.61 & $11 / 21 / 92$ & 93.61 & 93.07 & $7 / 20 / 95$ & 86.12 & 85.84 & $3 / 17 / 98$ & 95.57 & 94.96 \\
\hline $3 / 27 / 90$ & 96.15 & 95.52 & $11 / 22 / 92$ & 94.19 & 93.63 & $7 / 21 / 95$ & 85.75 & 85.48 & $3 / 18 / 98$ & 95.57 & 94.97 \\
\hline $3 / 28 / 90$ & 95.31 & 94.71 & $11 / 23 / 92$ & 94.71 & 94.13 & $7 / 22 / 95$ & 85.30 & 85.05 & $3 / 19 / 98$ & 95.67 & 95.06 \\
\hline $3 / 29 / 90$ & 94.37 & 93.80 & $11 / 24 / 92$ & 94.65 & 94.07 & $7 / 23 / 95$ & 84.88 & 84.64 & $3 / 20198$ & 95.601 & 94.99 \\
\hline $3 / 30 / 90$ & 93.82 & 93.27 & $11 / 25 / 92$ & 94.90 & 94.32 & $7 / 24 / 95$ & 84.93 & 84.69 & $3 / 21 / 98$ & 94.81 & 94.23 \\
\hline $3 / 31 / 90$ & 93.39 & 92.86 & $11 / 26 / 92$ & 95.08 & 94.49 & $7 / 25 / 95$ & 86.19 & 85.91 & $3 / 22 / 98$ & 94.87 & 94.29 \\
\hline $4 / 1 / 90$ & 90.95 & 90.50 & $11 / 27 / 92$ & 95.28 & 94.68 & $7 / 26 / 95$ & 88.15 & 87.80 & $3 / 23 / 98$ & 95.28 & 94.68 \\
\hline $4 / 2 / 90$ & 86.76 & 86.46 & $11 / 28 / 92$ & 95.96 & 95.34 & $7 / 27 / 95$ & 87.59 & 87.26 & $3 / 24 / 98$ & 95.47 & 94.86 \\
\hline $4 / 3 / 90$ & 86.33 & 86.04 & $11 / 29 / 92$ & 96.65 & 96.00 & $7 / 28195$ & 86.43 & 86.14 & $3 / 25 / 98$ & 95.30 & $\overline{94.70}$ \\
\hline $4 / 4 / 90$ & 85.93 & 85.65 & $11 / 30 / 92$ & 96.61 & 95.97 & $7 / 29 / 95$ & 86.04 & 85.76 & $3 / 26 / 98$ & 94.90 & 94.32 \\
\hline $4 / 5 / 90$ & 86.44 & 86.15 & $12 / 1 / 92$ & 96.27 & 95.64 & $7 / 30 / 95$ & 85.25 & 85.00 & $3 / 27 / 98$ & 94.36 & 93.79 \\
\hline $4 / 6 / 90$ & 85.98 & 85.70 & $12 / 2 / 92$ & 95.63 & 95.02 & $7 / 31 / 95$ & 85.58 & 85.32 & $3 / 28 / 98$ & & \\
\hline $4 / 7 / 90$ & 84.40 & 84.18 & $12 / 3 / 92$ & 95.46 & 94.86 & $8 / 1 / 95$ & 85.19 & 84.94 & $3 / 29 / 98$ & 94.21 & 93.65 \\
\hline $4 / 8 / 90$ & 83.88 & 83.68 & $12 / 4 / 92$ & 95.45 & 94.85 & $8 / 2 / 95$ & 85.68 & 85.41 & $3 / 30 / 98$ & 94.20 & 93.64 \\
\hline $4 / 9 / 90$ & 83.06 & 82.88 & $12 / 5 / 92$ & 94.80 & 94.22 & $8 / 3 / 95$ & 87.00 & 86.69 & $3 / 31 / 98$ & 94.00 & 93.45 \\
\hline $4 / 10 / 90$ & 84.53 & 84.30 & $12 / 6 \sqrt{92}$ & 94.92 & 94.33 & $8 / 4 / 95$ & 87.29 & 86.97 & $4 / 1 / 98$ & 93.34 & 92.81 \\
\hline $4 / 11 / 90$ & 87.70 & 87.36 & $12 / 7 / 92$ & 95.34 & 94.74 & $8 / 5 / 95$ & 86.79 & 86.49 & $4 / 2 / 98$ & 92.83 & 92.32 \\
\hline $4 / 12 / 90$ & 88.98 & 88.60 & $12 / 8 / 92$ & 95.58 & 94.97 & $8 / 6 / 95$ & 84.99 & 84.75 & $4 / 3 / 98$ & 92.38 & 91.88 \\
\hline $4 / 13 / 90$ & 89.11 & 88.72 & $12 / 9 / 92$ & 95.66 & 95.05 & $8 / 7 / 95$ & 84.98 & 84.74 & $4 / 4 / 98$ & 92.62 & 92.12 \\
\hline $4 / 14 / 90$ & 88.43 & 88.07 & $12 / 10 / 92$ & 95.74 & 95.13 & $8 / 8 / 95$ & 84.94 & 84.70 & $4 / 5 / 98$ & 93.88 & 93.33 \\
\hline $4 / 15 / 90$ & 86.41 & 86.12 & $12 / 11 / 92$ & 95.79 & 95.17 & $8 / 9 / 95$ & 85.70 & 85.43 & $4 / 6 / 98$ & 94.18 & 93.62 \\
\hline $4 / 16 / 90$ & 83.35 & 83.16 & $12 / 12 / 92$ & 95.78 & 95.16 & $8 / 10 / 95$ & 87.29 & 86.97 & $4 / 7 / 98$ & 93.52 & 92.98 \\
\hline $4 / 17 / 90$ & 84.53 & 84.30 & $12 / 13 / 92$ & 95.71 & 95.10 & $8 / 11 / 95$ & 84.74 & 84.51 & $4 / 8 / 98$ & 93.17 & 92.64 \\
\hline $4 / 18 / 90$ & 89.23 & 88.84 & $12 / 14 / 92$ & 95.70 & 95.09 & $8 / 12 / 95$ & 84.09 & 83.88 & $4 / 9 / 98$ & 93.16 & 92.64 \\
\hline $4 / 19 / 90$ & 89.86 & 89.45 & $12 / 15 / 92$ & 95.77 & 95.16 & $8 / 13 / 95$ & 85.12 & 84.87 & $4 / 10 / 98$ & 93.89 & 93.34 \\
\hline $4 / 20 / 90$ & 89.21 & 88.82 & $12 / 16 / 92$ & 95.83 & 95.21 & $8 / 14 / 95$ & 86.24 & 85.95 & $4 / 11 / 98$ & 94.93 & 94.34 \\
\hline $4 / 21 / 90$ & 88.51 & 88.15 & $12 / 17 / 92$ & 95.86 & 95.24 & $8 / 15 / 95$ & 85.15 & 84.90 & $4 / 12 / 98$ & 95.34 & 94.74 \\
\hline $4 / 22 / 90$ & 85.02 & 84.78 & $12 / 18 / 92$ & 95.67 & 95.06 & $8 / 16 / 95$ & 86.08 & 85.80 & $4 / 13 / 98$ & 95.48 & 94.88 \\
\hline $4 / 23 / 90$ & 82.90 & 82.73 & $12 / 19 / 92$ & 94.96 & 94.37 & $8 / 17 / 95$ & 87.01 & 86.70 & $4 / 14 / 98$ & 95.50 & 94.90 \\
\hline $4 / 24 / 90$ & 85.13 & 84.88 & $12 / 20 / 92$ & 94.90 & 94.32 & $8 / 18 / 95$ & 87.57 & 87.24 & $4 / 15 / 98$ & 95.41 & 94.81 \\
\hline $4 / 25 / 90$ & 86.02 & 85.74 & $12 / 21 / 92$ & 95.00 & 94.41 & $8 / 19 / 95$ & 87.18 & 86.86 & $4 / 16 / 98$ & 94.79 & 94.21 \\
\hline $4 / 26 / 90$ & 86.53 & 86.23 & $12 / 22 / 92$ & 95.27 & 94.67 & $8 / 20 / 95$ & 84.78 & 84.54 & $4 / 17 / 98$ & 94.69 & 94.11 \\
\hline $4 / 27 / 90$ & 86.79 & 86.49 & $12 / 23 / 92$ & 95.58 & 94.97 & $8 / 21 / 95$ & 84.45 & 84.23 & $4 / 18 / 98$ & 95.03 & 94.44 \\
\hline $4 / 28 / 90$ & 85.27 & 85.02 & $12 / 24 / 92$ & 95.78 & 95.16 & $8 / 22 / 95$ & 84.06 & 83.85 & $4 / 19 / 98$ & 95.37 & 94.77 \\
\hline $4 / 29 / 90$ & 84.24 & 84.02 & $12 / 25 / 92$ & 95.84 & 95.22 & $8 \longdiv { 2 3 / 9 5 }$ & 84.86 & 84.62 & $4 / 20 / 98$ & 95.58 & 94.97 \\
\hline
\end{tabular}


Appendix C (continued)

\section{SR-TNX Estimated Historic Daily Mean Elevation}

\begin{tabular}{|c|c|c|c|c|c|c|c|c|c|c|c|}
\hline Date & $\begin{array}{c}\text { SR- } \\
\text { Jackson } \\
\text { Elevation } \\
\text { (ft-msl) }\end{array}$ & $\begin{array}{l}\text { SR-TNX } \\
\text { Estimated } \\
\text { Elevation } \\
\text { (ft-ms!) }\end{array}$ & Date & $\begin{array}{c}\text { SR- } \\
\text { Jackson } \\
\text { Elevation } \\
\text { (ft-msl) }\end{array}$ & $\begin{array}{l}\text { SR-TNX } \\
\text { Estimated } \\
\text { Elevation } \\
\text { (ft-mst) }\end{array}$ & Date & $\begin{array}{c}\text { SR- } \\
\text { Jackson } \\
\text { Elevation } \\
\text { (fl-msl) }\end{array}$ & $\begin{array}{c}\text { SR-TNX } \\
\text { Estimated } \\
\text { Elevation } \\
\text { (ft-msl) }\end{array}$ & Date & $\begin{array}{c}\text { SR- } \\
\text { Jackson } \\
\text { Elevation } \\
(\mathrm{ft}-\mathrm{msl})\end{array}$ & \begin{tabular}{c|} 
SR-TNX \\
Estimated \\
Elcvation \\
$(\mathrm{ft}-\mathrm{msl})$
\end{tabular} \\
\hline $4 / 30 / 90$ & 83.78 & 83.58 & $12 / 26 / 92$ & 95.85 & 95.23 & $8 / 24 / 95$ & 85.03 & 84.79 & $4 / 21 / 98$ & 95.60 & 94.99 \\
\hline $5 / 1 / 90$ & 84.48 & 84.25 & $12 / 27 / 92$ & 95.85 & 95.23 & $8 / 25 / 95$ & 84.52 & 84.29 & $4 / 22 / 98$ & 95.63 & 95.02 \\
\hline $5 / 2 / 90$ & 86.17 & 85.89 & $12 / 28 / 92$ & 95.89 & 95.27 & $8 / 26 / 95$ & 85.26 & 85.01 & $4 / 23 / 98$ & $95.61 \mid$ & 95.00 \\
\hline $5 / 3 / 90$ & 86.61 & 86.31 & $12 / 29 / 92$ & 95.97 & 95.35 & $8 / 27 / 95$ & 87.51 & 87.18 & $4 / 24 / 98$ & 95.59 & 94.98 \\
\hline $5 / 4 / 90$ & 85.66 & 85.39 & $12 / 30 / 92$ & 95.77 & 95.16 & $8 / 28 / 95$ & 89.70 & 89.29 & $4 / 25 / 98$ & 95.53 & 94.93 \\
\hline $5 / 5 / 90$ & 84.18 & 83.97 & $12 / 31 / 92$ & 95.95 & \begin{tabular}{l|}
95.33 \\
\end{tabular} & $8 / 29 / 95$ & 90.25 & 89.83 & $4 / 26 / 98$ & 95.19 & 94.60 \\
\hline $5 / 6 / 90$ & 84.37 & 84.15 & 1/1/93 & 96.01 & 95.39 & $8 / 30 / 95$ & 89.21 & 88.82 & $4 / 27 / 98$ & 94.68 & 94.10 \\
\hline $5 / 7 / 90$ & 84.92 & 84.68 & $1 / 2 / 93$ & 95.93 & 95.31 & $8 / 31 / 95$ & 87.98 & 87.63 & $4 / 28 / 98$ & 94.40 & 93.83 \\
\hline $5 / 8 / 90$ & 86.91 & 86.60 & $1 / 3 / 93$ & 95.86 & 95.24 & 9/1/95 & 87.26 & 86.94 & $4 / 29 / 98$ & 94.15 & 93.60 \\
\hline $5 / 9 / 90$ & 86.69 & 86.39 & $1 / 4 / 93$ & 95.81 & 95.19 & $9 / 2 / 95$ & 87.19 & 86.87 & $4 / 30 / 98$ & 94.67 & 94.09 \\
\hline $5 / 10 / 90$ & 86.12 & 85.84 & $1 / 5 / 93$ & 95.82 & 95.20 & $9 / 3 / 95$ & 86.20 & 85.92 & $5 / 1 / 98$ & 95.22 & 94.62 \\
\hline $5 / 11 / 90$ & 85.83 & 85.56 & $1 / 6 / 93$ & 95.90 & 95.28 & $9 / 4 / 95$ & 86.34 & 86.05 & $5 / 2 / 98$ & 95.42 & 94.82 \\
\hline $5 / 12 / 90$ & 87.39 & 87.06 & $1 / 7 / 93$ & 96.08 & 95.45 & $9 / 5 / 95$ & 90.10 & 89.68 & $5 / 3198$ & 95.53 & 94.92 \\
\hline $5 / 13 / 90$ & 88.04 & 87.69 & $1 / 8 / 93$ & 96.51 & 95.87 & $9 / 6 / 95$ & 91.41 & 90.95 & $5 / 4 / 98$ & 95.52 & 94.91 \\
\hline $5 / 14 / 90$ & 85.58 & 85.32 & $1 / 9 / 93$ & 96.52 & 95.88 & $9 / 7 / 95$ & 89.18 & 88.79 & $5 / 5 / 98$ & 95.37 & 94.77 \\
\hline $5 / 15 / 90$ & 86.52 & 86.22 & $1 / 10 / 93$ & 95.98 & 95.36 & 9/8/95 & 86.72 & 86.42 & $5 / 6 / 98$ & 95.26 & 94.66 \\
\hline $5 / 16 / 90$ & 89.81 & 89.40 & $1 / 11 / 93$ & 95.81 & 95.19 & $9 / 9195$ & 88.15 & 87.80 & $5 / 7 / 98$ & 95.25 & 94.65 \\
\hline $5 / 17 / 90$ & 91.63 & 91.16 & $1 / 12 / 93$ & 95.71 & 95.10 & $9 / 10 / 95$ & 87.94 & 87.60 & $5 / 8 / 98$ & 95.38 & 94.78 \\
\hline $5 / 18 / 90$ & 92.28 & 91.79 & $1 / 13 / 93$ & 95.80 & 95.18 & $9 / 11 / 95$ & 86.70 & 86.40 & $5 / 9 / 98$ & 95.18 & 94.58 \\
\hline $5 / 19 / 90$ & 92.59 & 92.08 & $1 / 14 / 93$ & 96.40 & 95.76 & $9 / 12 K 5$ & 86.48 & 86.19 & $5 / 10 / 98$ & 93.93 & 93.38 \\
\hline $5 / 20 / 90$ & 92.77 & 92.26 & $1 / 15 / 93$ & 96.75 & 96.10 & $9 / 13 / 95$ & 86.76 & 86.46 & $5 / 11 / 98$ & 90.90 & 90.46 \\
\hline $5 / 21 / 90$ & 92.94 & 92.42 & $1 / 16 / 93$ & 96.57 & 95.93 & $9 / 14 / 95$ & 86.18 & 85.90 & $5 / 12 / 98$ & 90.89 & 90.45 \\
\hline $5 / 22 / 90$ & 92.93 & 92.41 & $1 / 17 / 93$ & 96.01 & 95.39 & $9 / 15 / 95$ & 87.37 & 87.05 & $5 / 13 / 98$ & 93.05 & 92.53 \\
\hline $5 / 23 / 90$ & 93.05 & 92.53 & $1 / 18 / 93$ & 95.79 & 95.17 & $9 / 16 / 95$ & \begin{tabular}{l|}
87.68 \\
\end{tabular} & 87.34 & $5 / 14 / 98$ & $\begin{array}{l}94.47 \\
\end{array}$ & 93.90 \\
\hline $5 / 24 / 90$ & 93.19 & 92.66 & $1 / 19 / 93$ & 96.07 & 95.44 & $9 / 17 / 95$ & 87.68 & 87.34 & $5 / 15 / 98$ & 95.04 & 94.45 \\
\hline $5 / 25 / 90$ & 93.26 & 92.73 & $1 / 20 / 93$ & 96.22 & 95.59 & $9 / 18 / 95$ & 86.24 & 85.95 & $5 / 16 / 98$ & 95.22 & 94.62 \\
\hline $5 / 26 / 90$ & 93.09 & 92.57 & $1 / 21 / 93$ & 96.32 & 95.69 & $9 / 19 / 95$ & 85.97 & 85.69 & $5 / 17 / 98$ & 95.28 & 94.68 \\
\hline $5 / 27 / 90$ & 90.63 & 90.19 & $1 / 22 / 93$ & 96.11 & 95.48 & $9 / 20 / 95$ & 86.57 & 86.27 & $5 / 18 / 98$ & 95.27 & 94.67 \\
\hline \multirow[t]{2}{*}{$5 / 28 / 90$} & 86.04 & 85.76 & $1 / 23 / 93$ & 95.08 & 94.49 & $9 / 21 / 95$ & 86.25 & 85.96 & $5 / 19 / 98$ & 94.40 & 93.84 \\
\hline & & & & & & & & & $5 / 20 / 98$ & 92.29 & 91.80 \\
\hline
\end{tabular}

\begin{tabular}{|c|c|c|c|c|c|c|}
\hline \multicolumn{7}{|c|}{ SR-TNX Estimated Daily Mean Elevation Statistics } \\
\hline Mean & Median & Minimum & Maximum & $\begin{array}{l}\text { \# of Daily } \\
\text { Readings }\end{array}$ & $\begin{array}{c}\text { \# of Daily } \\
\text { Reading } \\
>88.82\end{array}$ & $\begin{array}{c}\% \text { of Time } \\
>88.82\end{array}$ \\
\hline 86.70 & 85.43 & 80.94 & 96.11 & 3806 & 1024 & 26.90 \\
\hline
\end{tabular}


Appendix D

TNX GeoSiphon Cell Detailed Organic Data

\begin{tabular}{|c|c|c|c|}
\hline & Sample Date & $6 / 9 \longdiv { 9 8 }$ & $9 / 2 / 98$ \\
\hline & Sample Time & $12: 20-16: 00$ & $8: 08-10: 35$ \\
\hline & Flow (gpm) & 0 & 2.56 \\
\hline $\begin{array}{c}\text { Sample } \\
\text { Location }\end{array}$ & Parameter & $\begin{array}{c}\text { Concentration } \\
(\mu g / l)\end{array}$ & $\begin{array}{c}\text { Concentration } \\
(\mu \mathrm{g} / \mathrm{l})\end{array}$ \\
\hline TCM-2 & trichloroethylene & 234.1 & 109.6 \\
\hline TGSC-1A & trichloroethylene & 156.0 & NA \\
\hline TGSC-1B & trichloroethylene & 1.8 & NA \\
\hline TGSC-1C & trichloroethylene & 0.5 & NA \\
\hline TGSC-1D & trichloroethylene & 0.6 & NA \\
\hline TGSC-1E & trichlorocthylene & 0.5 & $\mathrm{NA}$ \\
\hline TGSC-1F & trichloroethylene & ND & NA \\
\hline TGSC-1G & trichloroethylene & ND & NA \\
\hline TGSC-1H & trichloroethylene & ND & $\overline{N A}$ \\
\hline TGSC-1 & trichloroethylene & ND & $\mathrm{ND}$ \\
\hline TCM-2 & cis-1,2-dichloroethylene & 28.2 & ND \\
\hline TGSC-1A & cis-1,2-dichloroethylene & 17.2 & $\mathrm{NA}$ \\
\hline TGSC-1B & cis-1,2-dichloroethylene & ND & NA \\
\hline TGSC-IC & cis-1,2-dichloroethylene & ND & $\overline{N A}$ \\
\hline TGSC-1D & cis-1,2-dichloroethylene & ND & NA \\
\hline TGSC-1E & cis-1,2-dichloroethylene & ND & NA \\
\hline TGSC-1F & cis-1,2-dichloroethylene & ND & NA \\
\hline TGSC-1G & cis-1,2-dichloroethylene & ND & NA \\
\hline TGSC-1H & cis-1,2-dichloroethylene & ND & NA \\
\hline TGSC-1 & cis-1,2-dichloroethylene & ND & $\mathrm{ND}$ \\
\hline TCM-2 & chloroform & 3.2 & 2.5 \\
\hline TGSC-1A & chloroform & 1.2 & NA \\
\hline TGSC-1B & chloroform & ND & NA \\
\hline TGSC-1C & chloroform & ND & NA \\
\hline TGSC-1D & chloroform & ND & NA \\
\hline TGSC-1E & chloroform & $\mathrm{ND}$ & NA \\
\hline TGSC-1F & chloroform & ND & NA \\
\hline TGSC-1G & chloroform & ND & NA \\
\hline TGSC-1H & chloroform & ND & NA \\
\hline TGSC-1 & chloroform & ND & ND \\
\hline TCM-2 & chloroform & 3.2 & 2.5 \\
\hline TGSC-1A & chloroform & 1.2 & NA \\
\hline TGSC-1B & chloroform & ND & NA \\
\hline TGSC-1C & chloroform & ND & NA \\
\hline TGSC-1D & chloroform & ND & NA \\
\hline TGSC-1E & chloroform & ND & NA \\
\hline TGSC-1F & chloroform & ND & NA \\
\hline TGSC-1G & chloroform & ND & NA \\
\hline TGSC-IH & chloroform & ND & $\mathrm{NA}$ \\
\hline TGSC-1 & chloroform & ND & $\mathrm{ND}$ \\
\hline
\end{tabular}
Notes:

1) $\mathrm{NA}=$ Not analyzed

2) $\mathrm{ND}=$ Not detected

3) Analyses performed by SRTC ERT 
Appendix E

TNX GeoSiphon Cell Detailed Field Data

\begin{tabular}{|c|c|c|c|}
\hline & Sample Date & $6 / 9 / 98$ & $9 / \overline{2 / 98}$ \\
\hline & Sample Time & $12: 20-16: 00$ & $8: 08-10: 35$ \\
\hline & Flow (gpm) & 0 & 2.56 \\
\hline Sample Location & Parameter, Units & Reading & Reading \\
\hline TCM-2 & $\overline{\mathrm{pH}}$ & 5.17 & 5.65 \\
\hline TGSC-1A & $\mathrm{pH}$ & 5.7 & NA \\
\hline TGSC-1B & $\mathrm{pH}$ & 6.25 & $\overline{\mathrm{NA}}$ \\
\hline TGSC-1C & $\mathrm{pH}$ & 6.28 & $\overline{\mathrm{NA}}$ \\
\hline TGSC-1D & $\overline{\mathrm{pH}}$ & 7.11 & NA \\
\hline TGSC-IE & $\mathrm{pH}$ & 7.63 & $\widehat{N A}$ \\
\hline TGSC-1F & $\mathrm{pH}$ & 8.56 & NA \\
\hline TGSC-1G & pH & 8.94 & $\overline{\mathrm{NA}}$ \\
\hline TGSC-1H & $\mathrm{pH}$ & 9.97 & NA \\
\hline TGSC-1 & pH & 9.6 & 9.6 \\
\hline TCM-2 & $\overline{\mathrm{DO}}, \mathrm{mg} / \mathrm{I}$ & 3.2 & $\overline{\mathrm{NA}}$ \\
\hline TGSC-1A & $\mathrm{DO}, \mathbf{m g} / 1$ & $4 . \overline{4}$ & NA \\
\hline TGSC-1B & $\mathrm{DO}, \mathrm{mg} / \mathrm{l}$ & 3.2 & NA \\
\hline TGSC-1C & $\mathrm{DO}, \mathrm{mg} / \mathrm{l}$ & 3.6 & NA \\
\hline TGSC-1D & $\mathrm{DO}, \mathrm{mg} / \mathrm{I}$ & 2.2 & NA \\
\hline TGSC-1E & $\mathrm{DO}, \mathrm{mg} / \mathrm{l}$ & 2.7 & $\mathbf{N A}$ \\
\hline TGSC-IF & $\overline{\mathrm{DO}}, \mathrm{mg} / \mathrm{I}$ & 2.2 & $\overline{N A}$ \\
\hline TGSC-1G & $\mathrm{DO}, \mathrm{mg} / \mathrm{l}$ & 2.3 & NÁ \\
\hline TGSC-IH & $\mathrm{DO}, \mathrm{mg} / \mathrm{I}$ & 2.3 & NA \\
\hline TGSC-1 & DO, mg/l & 2.1 & NA \\
\hline TCM-2 & Eh, mV & 387.2 & 353.3 \\
\hline TGSC-1A & Eh, mV & 418.6 & NA \\
\hline TGSC-1B & Eh, mV & 22.9 & NA \\
\hline TGSC-1C & Eh, $\mathrm{mV}$ & 7.5 & $\overline{N A}$ \\
\hline TGSC-1D & Eh, mV & -7.6 & $\overline{N A}$ \\
\hline TGSC-1E & Eh, mV & -25.2 & $\overline{N A}$ \\
\hline TGSC-IF & Eh, mV & -38.8 & $\overline{\mathrm{NA}}$ \\
\hline TGSC-1G & Eh, mV & -54.9 & NA \\
\hline TGSC-1H & $\mathrm{Eh}, \mathrm{mV}$ & -102.3 & NA \\
\hline TGSC -1 & $\mathrm{Eh}, \mathrm{mV}$ & -81.5 & -125.4 \\
\hline $\mathrm{TCM}-2$ & Temp. ${ }^{\circ} \mathrm{C}$ & $2 \overline{3.3}$ & 24 \\
\hline TGSC-1A & Temp. ${ }^{6} \mathrm{C}$ & 26.7 & NA \\
\hline TGSC-1B & Temp. ${ }^{\circ} \mathrm{C}$ & 24.7 & NA \\
\hline TGSC-1C & Temp. ${ }^{\circ} \mathrm{C}$ & 23.5 & $\mathrm{NA}$ \\
\hline TGSC-1D & Temp. ${ }^{\circ} \mathrm{C}$ & 23.8 & $\mathrm{NA}$ \\
\hline TGSC-1E & Temp. ${ }^{\circ} \mathrm{C}$ & 22.9 & NA \\
\hline TGSC-IF & Temp. ${ }^{\circ} \mathrm{C}$ & 23.2 & NA \\
\hline TGSC-1G & Termp. ${ }^{\circ} \mathrm{C}$ & 23.1 & NA \\
\hline TGSC-1H & Temp. ${ }^{\circ} \mathrm{C}$ & 22.9 & NA \\
\hline TGSC-1 & Temp. ${ }^{\circ} \mathrm{C}$ & 23.3 & 21.9 \\
\hline
\end{tabular}

1) NA $=$ Not analyzed

2) Readings taken by SRTC ERT 
Appendix $\mathrm{F}$

INX GeoSiphon Cell Detailed Inorganic Data

\begin{tabular}{|c|c|c|c|c|c|c|c|}
\hline $\begin{array}{c}\text { Sample } \\
\text { Location }\end{array}$ & $\begin{array}{l}\text { Distance into Cell } \\
\text { (fi) }\end{array}$ & $\begin{array}{c}\mathrm{Al} \\
(\mathrm{mg} / \mathrm{f})\end{array}$ & $\begin{array}{c}\mathrm{B} \\
(\mathrm{mg} / \mathrm{l})\end{array}$ & $\begin{array}{c}\mathrm{Ba} \\
(\mathrm{mg} / \mathrm{f})\end{array}$ & $\begin{array}{c}\mathrm{Ca} \\
(\mathrm{mg} / \mathrm{l})\end{array}$ & $\begin{array}{c}\mathrm{Cd} \\
(\mathrm{mg} / \mathrm{l})\end{array}$ & $\underset{(\mathrm{mg} /)}{\mathrm{Cr}}$ \\
\hline TCM-2 & 0 & $<0.116$ & 0.095 & $<0.008$ & 2.713 & $<0.004$ & $<0.009$ \\
\hline TGSC-1A & 0 & $<0.116$ & 0.012 & $<0.008$ & 3.635 & $<0.004$ & $<0.009$ \\
\hline TGSC-1B & 0.14 & $<0.116$ & $<0.011$ & $<0.008$ & 2.139 & $<0.004$ & $<0.009$ \\
\hline TGSC-1C & 0.32 & $<0.116$ & $<0.011$ & $<0.008$ & 5.427 & $<0.004$ & $<0.009$ \\
\hline TGSC-1D & 0.64 & $<0.116$ & $<0.011$ & $<0.008$ & 4.365 & $<0.004$ & $<0.009$ \\
\hline TGSC-1E & 1.07 & $<0.116$ & $<0.011$ & $<0.008$ & 2.816 & $<0.004$ & $<0.009$ \\
\hline TGSC-IF & 1.5 & $<0.116$ & $<0.011$ & $<0.008$ & 1.252 & $<0.004$ & $<0.009$ \\
\hline TGSC-IG & 2.04 . & $<0.116$ & $<0.011$ & $<0.008$ & 0.810 & $<0.004$ & $<0.009$ \\
\hline TGSC-1H & 2.86 & $<0.116$ & 0.244 & $<0.008$ & 1.896 & $<0.004$ & $<0.009$ \\
\hline TGSC-1 & 3.47 & 0.144 & 0.042 & $<0.008$ & 1.239 & $<0.004$ & $<0.009$ \\
\hline $\begin{array}{l}\text { Sample } \\
\text { Location } \\
\end{array}$ & $\begin{array}{c}\text { Distance into Cell } \\
\text { (ft) }\end{array}$ & $\begin{array}{c}\mathrm{Cu} \\
(\mathrm{mg} / \mathrm{l})\end{array}$ & $\begin{array}{c}\mathrm{Fe} \\
(\mathrm{mg} / \mathrm{l})\end{array}$ & $\begin{array}{c}\mathrm{Mg} \\
(\mathrm{mg} /)\end{array}$ & $\begin{array}{c}\mathrm{Mn} \\
(\mathrm{mg} / \mathrm{l})\end{array}$ & $\begin{array}{c}\text { Mo } \\
(\mathrm{mg} / \mathrm{l})\end{array}$ & $\begin{array}{c}\mathrm{Na} \\
(\mathrm{mg} /)\end{array}$ \\
\hline TCM-2 & 0 & $<0.014$ & 0.159 & 1.068 & 0.049 & $<0.011$ & 20.282 \\
\hline TGSC-1A & 0 & $<0.014$ & 0.162 & 1.752 & 0.031 & $<0.011$ & 8.932 \\
\hline TGSC-1B & 0.14 & $<0.014$ & 7.504 & 0.585 & 0.272 & $<0.011$ & 1.630 \\
\hline TGSC-IC & 0.32 & $<0.014$ & 2.350 & 1.081 & 0.165 & $<0.011$ & 1.533 \\
\hline TGSC-1D & 0.64 & $<0.014$ & 0.701 & 0.887 & 0.061 & $<0.011$ & 1.716 \\
\hline TGSC-1E & 1.07 & $<0.014$ & 0.298 & 0.421 & 0.024 & $<0.011$ & 2.047 \\
\hline TGSC-1F & 1.5 & $<0.014$ & 0.083 & 0.149 & 0.005 & $<0.011$ & 3.203 \\
\hline TGSC-1G & 2.04 & $<0.014$ & 0.045 & 0.086 & $<0.003$ & $<0.011$ & 2.941 \\
\hline TGSC-1H & 2.86 & 50.014 & 0.674 & 0.012 & $<0.003$ & 0.59 & 13.674 \\
\hline TGSC-1 & 3.47 & $<0.014$ & 0.231 & 0.197 & 0.009 & $<0.011$ & 4.479 \\
\hline $\begin{array}{c}\text { Sample } \\
\text { Location }\end{array}$ & $\begin{array}{l}\text { Distance into Cell } \\
\text { (ft) }\end{array}$ & $\begin{array}{c}\mathrm{Ni} \\
(\mathrm{mg} /)\end{array}$ & $\stackrel{\mathrm{P}}{(\mathrm{mg} / \mathrm{l})}$ & $\begin{array}{c}\mathrm{Si} \\
(\mathrm{mg} / \mathrm{l})\end{array}$ & $\begin{array}{c}\mathrm{Sr} \\
(\mathrm{mg} / \mathrm{l})\end{array}$ & $\begin{array}{c}\mathrm{Zn} \\
(\mathrm{mg} /)\end{array}$ & $\begin{array}{c}\text { Chloride } \\
\text { (mg/l) }\end{array}$ \\
\hline TCM-2 & 0 & $<0.015$ & $<0.029$ & 4.751 & $<0.004$ & $<0.004$ & 5.0 \\
\hline TGSC-1A & 0 & $<0.015$ & $<0.029$ & 4.274 & $<0.004$ & $<0.004$ & 3 \\
\hline TGSC-1B & 0.14 & $<0.015$ & $<0.029$ & $<0.069$ & $<0.006$ & $<0.004$ & 7 \\
\hline TGSC-1C & 0.32 & $<0.015$ & $<0.029$ & $<0.069$ & 0.014 & $<0.004$ & 15 \\
\hline TGSC-ID & 0.64 & $<0.015$ & $<0.029$ & $<0.069$ & 0.006 & $<0.004$ & 8 \\
\hline TGSC-1E & 1.07 & $<0.015$ & $<0.029$ & $<0.069$ & $<0.004$ & $<0.004$ & 2 \\
\hline TGSC-1F & 1.5 & $<0.015$ & $<0.029$ & $<0.069$ & $<0.004$ & $<0.004$ & 4 \\
\hline TGSC-1G & 2.04 & $<0.015$ & $<0.029$ & $<0.069$ & $<0.004$ & $<0.004$ & 3 \\
\hline TGSC-1H & 2.86 & $<0.015$ & $<0.029$ & $<0.069$ & 0.040 & $<0.004$ & 4 \\
\hline TGSC-1 & 3.47 & $<0.015$ & $<0.029$ & 1.192 & $<0.004$ & $<0.004$ & 41 \\
\hline $\begin{array}{l}\text { Sample } \\
\text { Location } \\
\end{array}$ & $\begin{array}{c}\text { Distance into Cell } \\
\text { (f) }\end{array}$ & $\begin{array}{c}\text { Fluotide } \\
\text { (mg/) }\end{array}$ & $\begin{array}{c}\text { Formate } \\
(\mathrm{mg} /)\end{array}$ & $\begin{array}{l}\text { Nitrate } \\
(\mathrm{mg} /)\end{array}$ & $\begin{array}{l}\text { Nitrite } \\
(\mathrm{mg} / \mathrm{)})\end{array}$ & $\begin{array}{l}\text { Sulfate } \\
(\mathrm{mg} / \mathrm{l})\end{array}$ & \\
\hline TCM-2 & 0 & $<0.2$ & $<1$ & 45.0 & $<1$ & 10.0 & \\
\hline TGSC-1A & 0 & $<0.2$ & $<1$ & 11 & $<1$ & 5 & \\
\hline TGSC-1B & 0.14 & $<0.2$ & $<1$ & $<1$ & $<1$ & I & \\
\hline TGSC-1C & 0.32 & $<0.2$ & $<1$ & $<1$ & $<1$ & 0.7 & \\
\hline TGSC-1D & 0.64 & $<0.2$ & $<1$ & $<1$ & $<1$ & 0.9 & \\
\hline TGSC-IE & 1.07 & $<0.2$ & $<1$ & $<1$ & $<1$ & 0.9 & \\
\hline TGSC-1F & 1.5 & $<0.2$ & $<1$ & $<1$ & $<1$ & 0.8 & \\
\hline TGSC-1G & 2.04 & $<0.2$ & $<1$ & $<1$ & $<1$ & 0.4 & \\
\hline TGSC-1H & 2.86 & $<0.2$ & $<1$ & $<1$ & $<1$ & 27 & \\
\hline TGSC-1 & 3.47 & $<0.2$ & $<1$ & $<1$ & $<1$ & 0.6 & \\
\hline
\end{tabular}


Notes to Appendix F, TNX GeoSiphon Cell Detailed Inorganic Data:

1) Samples taken on $6 / 9 / 98$

2) Only parameters, which had at least one analysis above detection during Phase I or II, are shown in the table.

3) The following parameters were all below their respective detection limits:

$\mathrm{Ag}(<0.017) ; \mathrm{Co}(<0.011) ; \mathrm{La}(<0.022) ; \mathrm{Li}(<0.012) ; \mathrm{Pb}(<0.066) ; \mathrm{Sn}(<0.016)$;

$\mathrm{Ti}(<0.011)$; V $(<0.014) ; \mathrm{Zr}(<0.017)$; Oxalate $(<1)$; Phosphate $(<1)$

4) Analyses performed by SRTC ADS 
Appendix $\mathrm{G}$

TNX GeoSiphon Cell Detailed Gas Analyses

\begin{tabular}{||l|c|c|c|c||}
\hline Parameter & Units & Sample & Duplicate & Average \\
\hline Carbon Dioxide & $\% / \mathrm{v}$ & $<0.01$ & $<0.01$ & $<0.01$ \\
\hline Oxygen & $\% / \mathrm{v}$ & 4.96 & 4.79 & 4.875 \\
\hline Nitrogen & $\% / \mathrm{v}$ & 46.42 & 46.07 & 46.245 \\
\hline Carbon Monoxide & $\% / \mathrm{v}$ & $<0.01$ & $<0.01$ & $<0.01$ \\
\hline Methane & $\% / \mathrm{v}$ & 1.95 & 1.99 & 1.97 \\
\hline Ethane & $\mathrm{ppmv}$ & 41.44 & 42.07 & 41.755 \\
\hline Ethylene & $\mathrm{ppmv}$ & 6.08 & 6.18 & 6.13 \\
\hline Propane & $\mathrm{ppmv}$ & 11.18 & 11.37 & 11.275 \\
\hline Propylene & $\mathrm{ppmv}$ & 4.95 & 5.04 & 4.995 \\
\hline I-Butane & $\mathrm{ppmv}$ & 0.97 & 1.00 & 0.985 \\
\hline n-Butane & $\mathrm{ppmv}$ & 4.53 & 4.57 & 4.55 \\
\hline Hydrogen & $\mathrm{ppmv}$ & 412,846 & 407,039 & 409942.5 \\
\hline Vinyl Chloride & $\mathrm{ppmv}$ & $<3$ & $<3$ & $<3$ \\
\hline Methylene Chloride & $\mathrm{ppmv}$ & $<2$ & $<2$ & $<2$ \\
\hline trans-1,2-Dichloroethylene & $\mathrm{ppmv}$ & $<0.1$ & $<0.1$ & $<0.1$ \\
\hline cis-1,2-Dichloroethylene & $\mathrm{ppmv}$ & $<0.1$ & $<0.1$ & $<0.1$ \\
\hline Chloroform & $\mathrm{ppmv}$ & $<0.005$ & $<0.005$ & $<0.005$ \\
\hline 1,1,1-Trichloroethane & $\mathrm{ppmv}$ & 0.009 & $<0.005$ & 0.007 \\
\hline Carbon Tetrachloride & $\mathrm{ppmv}$ & $<0.005$ & $<0.005$ & $<0.005$ \\
\hline Trichloroethylene & $\mathrm{ppmv}$ & 0.008 & 0.019 & 0.0135 \\
\hline Tetrachloroethylene & $\mathrm{ppmv}$ & $<0.005$ & $<0.005$ & $<0.005$ \\
\hline N & & \multicolumn{3}{|c}{} \\
\hline
\end{tabular}

Notes:

1) Samples taken on $8 / 24 / 98$

2) Analyses performed by Microseeps 